\title{
Uranium Contamination in the 300 Area: Emergent Data and Their Impact on the Source Term Conceptual Model
}

\author{
CF Brown \\ W Um \\ RJ Serne
}

September 2008

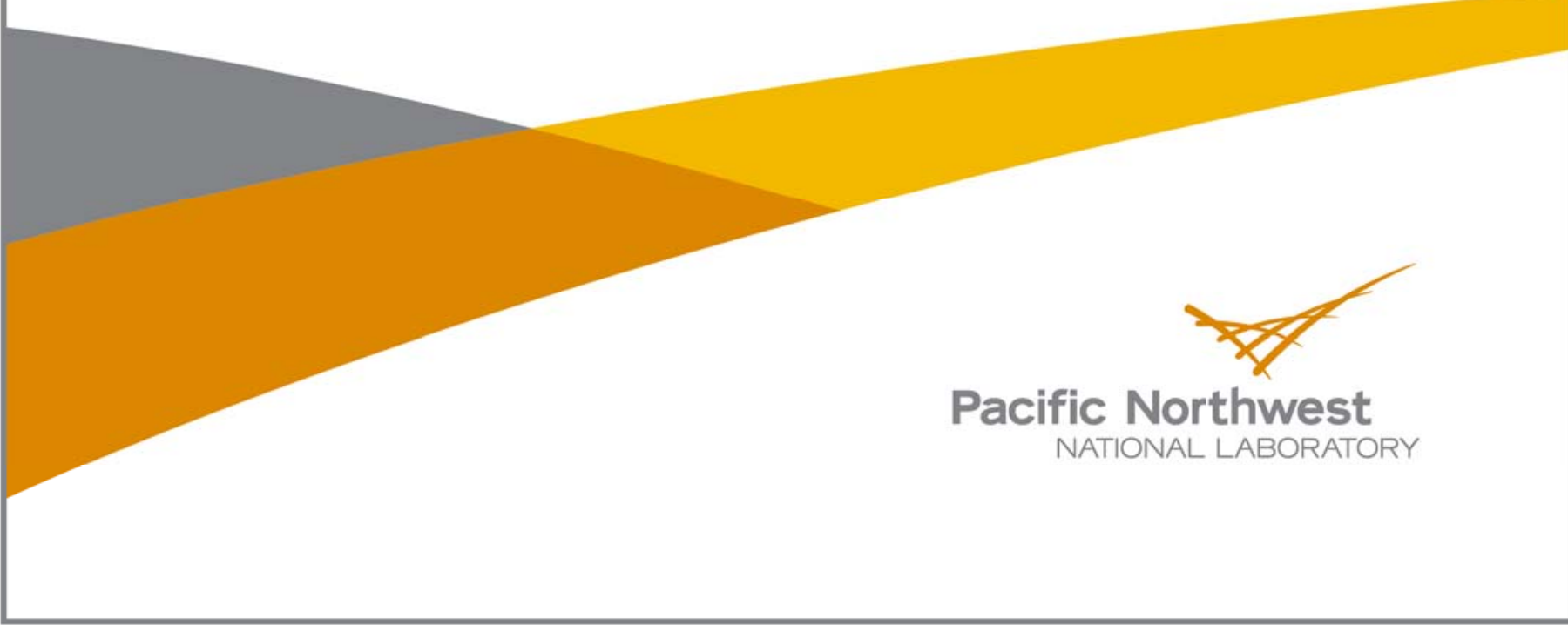




\title{
DISCLAIMER
}

This report was prepared as an account of work sponsored by an agency of the United States Government. Neither the United States Government nor any agency thereof, nor Battelle Memorial Institute, nor any of their employees, makes any warranty, express or implied, or assumes any legal liability or responsibility for the accuracy, completeness, or usefulness of any information, apparatus, product, or process disclosed, or represents that its use would not infringe privately owned rights. Reference herein to any specific commercial product, process, or service by trade name, trademark, manufacturer, or otherwise does not necessarily constitute or imply its endorsement, recommendation, or favoring by the United States Government or any agency thereof, or Battelle Memorial Institute. The views and opinions of authors expressed herein do not necessarily state or reflect those of the United States Government or any agency thereof.

\author{
PACIFIC NORTHWEST NATIONAL LABORATORY \\ operated by \\ BATTELLE \\ for the \\ UNITED STATES DEPARTMENT OF ENERGY \\ under Contract DE-AC05-76RL01830
}

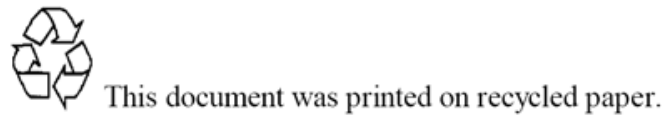

(9/2003) 


\title{
Uranium Contamination in the 300 Area: Emergent Data and Their Impact on the Source Term Conceptual Model
}

\author{
CF Brown \\ W Um \\ RJ Serne
}

September 2008

Prepared for

the U.S. Department of Energy

under Contract DE-AC05-76RL01830

Pacific Northwest National Laboratory

Richland, Washington 99352 



\section{Executive Summary}

Several characterization campaigns have been conducted by Pacific Northwest National Laboratory in the 300 Area over the last 10 years. The primary objectives of these efforts were to define inventories of contaminant uranium in the subsurface environment and to identify the mechanism(s) controlling the mobility (i.e., leaching and sorption) of uranium in the 300 Area. In addition to providing insight on the fate of contaminant uranium in the vadose zone, data from these studies were used to create a "box model" of the inventory of uranium in sediments and groundwater beneath the 300 Area (Peterson et al. 2008a). While a significant amount of scientific information has been gathered as a result of these activities, there are still uncertainties regarding the location and inventory of contaminant uranium in the 300 Area vadose zone and aquifer. These uncertainties present obstacles for evaluating remediation options for the persistent uranium plume in groundwater.

Opportunistic sediment samples collected during a drilling campaign in 2007 became available for uranium characterization in 2008. The primary objectives of this characterization activity were to 1) determine the extent of uranium contamination in the sediments, 2) quantify the leachable (labile) concentration of uranium in the sediments, and 3) create a data set that could be used to correlate the present data to existing 300 Area data. To meet these objectives, sediments collected from boreholes 399-2-5, 399-3-22, and 399-4-14 were analyzed for key geochemical parameters that are relevant to the sequestration and mobility of contaminant uranium. The following paragraphs summarize key findings of these characterization activities and include conclusions based on interpretation of the data from these studies as well as reinterpretation of results from other 300 Area characterization campaigns.

The unconfined aquifer within the 300 Area groundwater system extends from the Hanford formation through the Ringold Formation to the Lower mud unit that acts as a confining layer between the unconfined aquifer system and the basalt confined aquifer system. Within the unconfined aquifer, the Hanford formation and Ringold Formation exhibit drastically different permeabilities. The Hanford formation gravels are quite hydraulically transmissive and tend to contain the bulk of the uranium contaminated groundwater. Conversely, the finer-grained sediment of the Ringold Formation is much less permeable and contains trace to moderate amounts of uranium at the three locations interrogated by these boreholes.

Concentrations of water-extractable uranium were quite dilute in sediments from all three of the boreholes. It was unexpected that the sediments collected farthest from the known 300 Area waste sites contained the greatest concentrations of water-extractable uranium. A similar profile of contaminant uranium was evident in all three of the boreholes. At all locations, the peak concentrations of waterextractable uranium were found in the deep vadose zone and capillary fringe. This is particularly problematic because it is exactly this region of the subsurface that is affected during fluctuations in Columbia River stage elevation. During times of elevated river stage, river water infiltrates the vadose zone beneath the 300 Area and serves to raise the elevation of the water table. The elevated water table will come into contact with the contaminant uranium present in the vadose zone sediments and leach some fraction of it from the sediments, thereby replenishing the current groundwater plume underlying the 300 Area.

Results from the acid extracts and microwave digestions of sediments from all three of the boreholes indicated that the total concentrations of uranium in the sediments were quite dilute. The peak

microwave-digestible uranium concentrations in the $<2 \mathrm{~mm}$ size fraction ranged from 3.04 to $5.50 \mu \mathrm{g} / \mathrm{g}$ 
in the three boreholes. These results were particularly surprising because one of the boreholes (399-2-5) was drilled directly through the former 316 South Process Pond and was expected to encounter significant quantities of contaminant uranium. Like the water extraction data, the peak acid-extractable and microwave-digestible uranium was always encountered in sediments collected within the deep vadose zone and capillary fringe. The overall low concentrations of uranium in these sediments contrast with values estimated in an earlier "box model," which attributed a large portion of uranium inventory to the vadose zone directly beneath known disposal facilities. Alternatively, there is new evidence for a dilute but extensive source of contaminant uranium residing just above the water table throughout much of the 300 Area.

Equilibrium distribution coefficient $\left(\mathrm{K}_{\mathrm{d}}\right)$ values, calculated using the water extract and acid digest or microwave extract data, were considerably variable and indicated that the contaminant uranium could be classified as mobile $\left(K_{d}\right.$ value less than $\left.1 \mathrm{~mL} / \mathrm{g}\right)$ to very immobile $\left(\mathrm{K}_{\mathrm{d}}\right.$ values greater than $\left.100 \mathrm{~mL} / \mathrm{g}\right)$. Not only were there differences among samples collected from the three boreholes, there were observed differences between samples collected from different depths within a single borehole. For example, some of the highest calculated equilibrium $\mathrm{K}_{\mathrm{d}}$ values were for the samples collected near or just above the water table. This is particularly important because the depths from which these samples were collected are those most susceptible to changes in water table elevation. As the water table rises and falls, these sediments will go through repeated wetting and drying cycles. A long-standing hypothesis has suggested that as the sediments become saturated, some of the uranium contained in them will slowly leach into the groundwater, thus providing a long-term source of uranium to the aquifer.

Batch leach tests focused on determining the concentration of labile uranium in the sediments revealed two primary trends. The first trend involved a rather rapid release of uranium from the sediment. This initial release occurred within the first seven days of reaction and accounted for approximately $85 \%$ of the total amount of uranium removed from the sediments. The second trend can be characterized as a slow, continual release of uranium from the sediments. The kinetics of the second trend extended beyond 28 days of reaction time because steady-state uranium solution concentrations were not achieved for any of the samples analyzed. The two trends evident in these experiments likely result from two types of uranium being present in the sediments. The first type of uranium present, which readily leaches upon contact with the carbonate/bicarbonate leachant solution, is likely present as an easily removable sorbed species. Conversely, the remaining uranium that can be characterized by a very slow leach rate is likely present as discrete uranium-bearing minerals microprecipitated or sorbed to or physically trapped in a recalcitrant mineral phase such as nanocrystalline iron oxide coatings.

Although uranium desorption from the 300 Area sediments is complex and depends on many factors that were only partially elucidated by the macroscopic batch and modeling results, the river water influx and mixing with groundwater or pore water in the capillary fringe results in highly dynamic changes in pore water chemistry and is a main mechanism controlling the continuous resupply of dissolved U(VI) to the existing 300 Area groundwater plume. That is, uranium from the contaminated sediments both above and just below the fluctuating water table is slowly entering the 300 Area groundwater system through desorption and/or dissolution processes. In addition, the dissolved uranium can also be re-adsorbed to sediments due to decreased carbonate concentrations when the more saline groundwater becomes diluted by Columbia River water during high river stage. This fluctuating water table elevation and varying pore water chemical composition caused by seasonal and diurnal variations in the river stage can result in alternating adsorption-desorption processes that retard the migration of uranium to the Columbia River in a timely way. 


\section{Acronyms and Abbreviations}

$\begin{array}{ll}\text { ASTM } & \text { American Society for Testing and Materials } \\ \text { bgs } & \text { below ground surface } \\ \text { DOE } & \text { U.S. Department of Energy } \\ \text { DUP } & \text { duplicate (sample) } \\ \text { EC } & \text { electrical conductivity } \\ \text { EPA } & \text { U.S. Environmental Protection Agency } \\ \text { HCl } & \text { hydrochloric acid } \\ \text { HEIS } & \text { Hanford Environmental Information System } \\ \text { HF } & \text { hydrofluoric acid } \\ \text { HNO } & \text { nitric acid } \\ \text { IC } & \text { ion chromatography } \\ \text { ICP-MS } & \text { inductively coupled plasma-mass spectrometry } \\ \text { K } & \text { partition or distribution coefficient } \\ \text { LFI } & \text { limited field investigation } \\ \text { NDIR } & \text { nondispersive infrared } \\ \text { NPP } & \text { North Process Pond } \\ \text { PNNL } & \text { Pacific Northwest National Laboratory } \\ \text { SGW } & \text { synthetic groundwater } \\ \text { SPP } & \text { South Process Pond } \\ \text { TCE } & \text { trichloroethylene } \\ \text { UFA } & \text { ultracentrifuge apparatus } \\ \text { VOC } & \text { volatile organic compound } \\ \text { WSCF } & \text { Waste Sampling and Characterization Facility }\end{array}$





\section{Acknowledgments}

The authors benefited from careful and thoughtful content reviews by JP Icenhower, RM Smith, and RE Peterson. DC Lanigan produced the detailed cross sections and composite borehole logs that are so helpful in telling the story. MJ Parker produced the final layout and assembly of this report, and SQ Bennett provided a final technical edit of the document. The authors are particularly grateful for the support they received from the Environmental Sciences Laboratory staff, including SR Baum, ET Clayton, KN Geiszler, C Iovin, IV Kutnyakov, MJ Lindberg, DM Smith, MM Valenta, and BD Williams. 



\section{Contents}

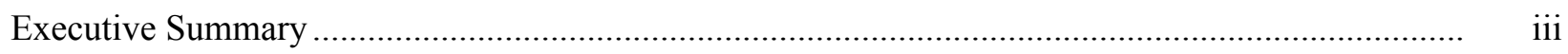

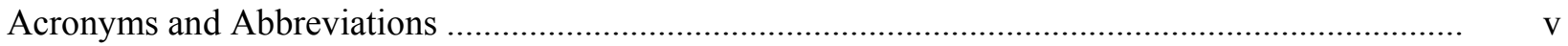

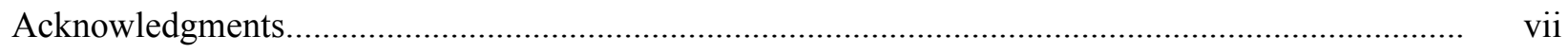

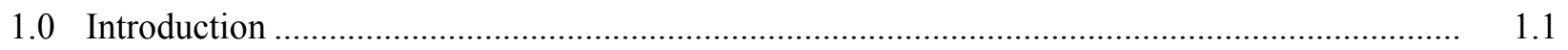

1.1 Current 300 Area Characterization Activities ............................................................... 1.1

1.2 Drilling and Characterization Methodology ................................................................ 1.2

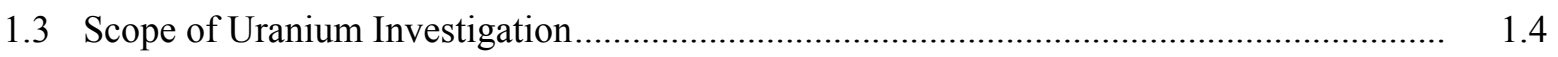

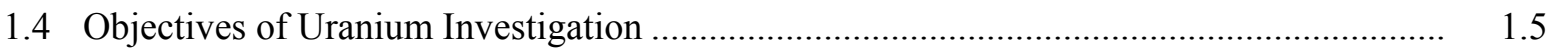

2.0 Previous Characterization Activities ........................................................................... 2.1

2.1300 Area Uranium Leach and Adsorption Project ....................................................... 2.1

2.2 Uranium Geochemistry in Vadose Zone and Aquifer Sediments from the 300 Area

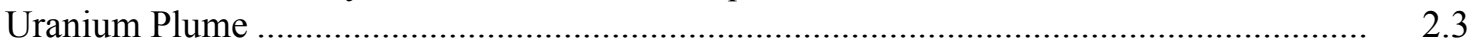

2.3 Limited Field Investigation Report for Uranium Contamination in the 300-FF-5 Operable Unit at the 300 Area, Hanford Site, Washington ............................................ 2.4

2.4 Uranium Contamination in the Subsurface Beneath the 300 Area, Hanford Site,

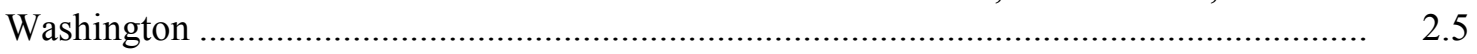

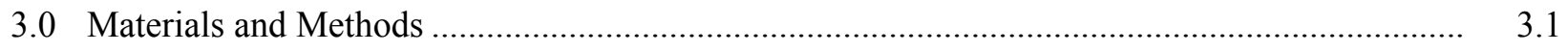

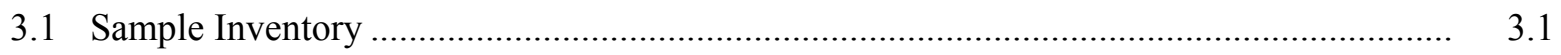

3.1.1 Well 399-2-5 (Borehole C5708).................................................................. 3.1

3.1.2 Well 399-3-22 (Borehole C5706)..................................................................... 3.1

3.1.3 Well 399-4-14 (Borehole C5707)....................................................................... 3.1

3.2 Analytical Procedures and Methods ....................................................................... 3.4

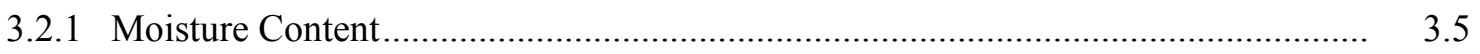

3.2.2 1:1 Sediment:Water Extracts .......................................................................... 3.5

3.2.3 8 M Nitric Acid Extract.................................................................................. 3.6

3.2.4 Microwave-Assisted Sample Digestion ............................................................ 3.6

3.2.5 Labile Uranium Leaching Using Sodium (Bi) Carbonate Solution ......................... 3.6

3.2.6 Pore Water Composition ................................................................................. 3.6

3.2.7 Total and Inorganic Carbon Content ................................................................ 3.6

3.3 Additional Characterization Activities ....................................................................... 3.7

3.3.1 Groundwater analyses ....................................................................... 3.7

3.3.2 Repetitive Washing and U(VI) Adsorption Isotherm......................................... 3.7

3.3.3 Modeling of U(VI) Adsorption and Desorption .................................................. 3.9

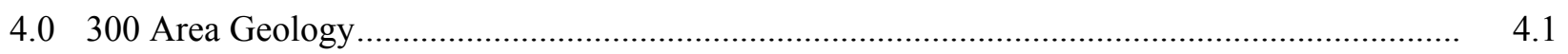

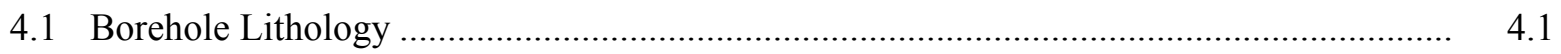

4.1.1 Surficial Sediment (Holocene) …….................................................................... 4.2

4.1.2 Hanford Formation (Unit 1) ..................................................................... 4.2 
4.1.3 Ringold Formation Undesignated Finer-Grained Interval (Unit 5) ........................ 4.3

4.1.4 Ringold Formation Coarse Gravel (Unit 5) .......................................................

4.1.5 Ringold Formation Lower Mud (Unit 8) ........................................................

5.0 Geochemical Results and Discussion ............................................................................ 5.1

5.1 Sediment from Well 399-2-5 (Borehole C5708)........................................................... 5.1

5.1 .1 Moisture Content .......................................................................................... 5.1

5.1.2 1:1 Sediment:Water Extracts of Sediments from Well 399-2-5 _........................... 5.1

5.1.3 Pore Water Chemical Composition .................................................................... 5.7

5.1.4 8 M Nitric Acid-Extractable and Microwave-Assisted Digestible Concentrations of Uranium-238 in Sediments from Well 399-2-5 ................................................. 5.11

5.1.5 Labile Uranium Leach Test Results ................................................................ 5.14

5.1.6 Total Carbon, Calcium Carbonate, and Organic Carbon Content of Sediment

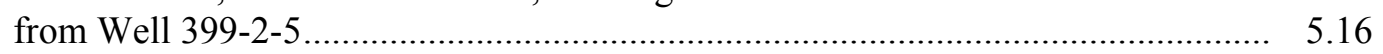

5.1.7 Analysis of Groundwater Samples from Well 399-2-5 ......................................... 5.17

5.2 Sediment from Well 399-3-22 (Borehole C5706) ............................................................. 5.19

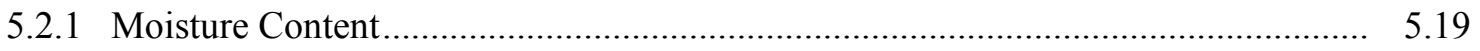

5.2.2 1:1 Sediment:Water Extracts of Sediments from Well 399-3-22 _.......................... 5.20

5.2.3 Pore Water Chemical Composition .................................................................. 5.24

5.2.4 8 M Nitric Acid-Extractable and Microwave-Assisted Digestible Concentrations of Uranium-238 in Sediments from Well 399-3-22 ........................................... 5.28

5.2.5 Labile Uranium Leach Test Results ................................................................ 5.31

5.2.6 Total Carbon, Calcium Carbonate, and Organic Carbon Content of Sediment from Well 399-3-22 ....................................................................................... 5.33

5.2.7 Analysis of Groundwater Samples from Well 399-3-22 .................................... 5.33

5.3 Sediment from Well 399-4-14 (Borehole C5707)......................................................... 5.36

5.3 .1 Moisture Content ......................................................................................... 5.36

5.3.2 1:1 Sediment:Water Extracts of Sediments from Well 399-4-14 _......................... 5.37

5.3.3 Pore Water Chemical Composition ............................................................... 5.40

5.3.4 8 M Nitric Acid-Extractable and Microwave-Assisted Digestible Concentrations of Uranium-238 in Sediments from Well 399-4-14 ............................................. 5.43

5.3.5 Labile Uranium Leach Test Results ..................................................................... 5.45

5.3.6 Total Carbon, Calcium Carbonate, and Organic Carbon Content of Sediment from Well 399-4-14 ..................................................................................... 5.46

5.3.7 Analysis of Groundwater Samples from Well 399-4-14 ...................................... 5.47

5.4 U(VI) Adsorption and Desorption for the LFI Well Sediments (Boreholes C4999

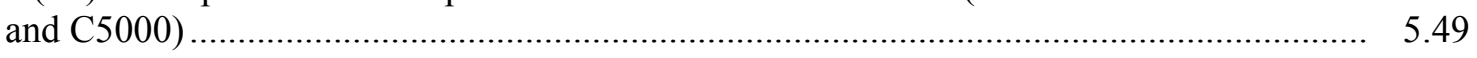

5.4.1 Sediment Characterization .............................................................................. 5.49

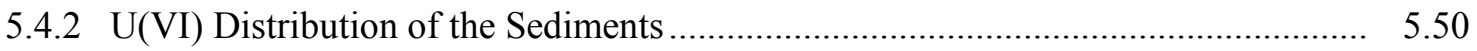

5.4.3 Labile U(VI) Concentrations by Bicarbonate Leaching ...................................... 5.51

$5.4 .4 \mathrm{U}(\mathrm{VI})$ Adsorption Isotherm and Modeling...................................................... 5.51 
5.4.5 U(VI) Desorption by Repetitive Washing and Modeling.

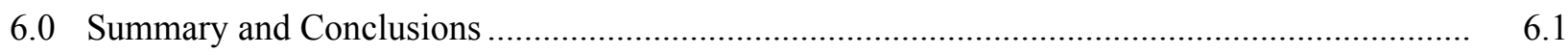

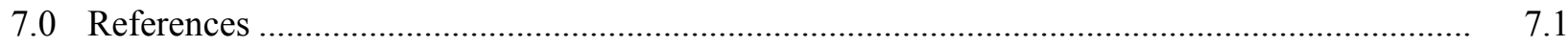

Appendix A - Composite Borehole Logs for VOC Investigation ................................................. A.1

Appendix B - Geologist Logs for Uranium Investigation Boreholes............................................ B. 1

Appendix C - Photographs of Samples Collected from Borehole C5708 …................................... C.1

Appendix D - Photographs of Samples Collected from Borehole C5707 ....................................... D. D.

Appendix E - Photographs of Samples Collected from Borehole C5706 ....................................... E.1

Appendix F - Stiff Diagrams of Groundwater Samples Collected from the VOC Wells.................... F.1 


\section{Figures}

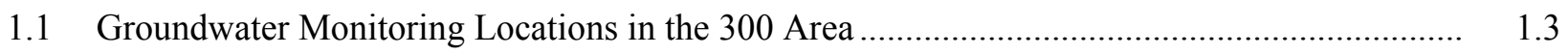

1.2 Cross Section Southwest to Northeast Across the 300 Area ................................................ 1.6

1.3 Cross Section West to East Across the 300 Area ................................................................ 1.7

2.1 Uranium Inventory in Various Compartments in the 300 Area Subsurface ........................... 2.7

4.1 Principal Hydrogeologic Units Beneath the 300 Area ........................................................ 4.1

5.1 Concentration of Water-Extractable Uranium-238 in Sediments from Well 399-2-5 .............. 5.6

5.2 EC Measurements of Sediments from Well 399-2-5 ...................................................... 5.8

5.3 Concentration of Acid-Extractable and Microwave-Digestible Uranium-238 in Sediments from Well 399-2-5 ....................................................................................... 5.13

5.4 Concentration of Labile Uranium-238 in Sediments from Well 399-2-5 as Measured in Bicarbonate/Carbonate Batch Leach Tests ................................................................... 5.15

5.5 Concentration of Water-Extractable Uranium-238 in Sediments from Well 399-3-22 ............. 5.24

5.6 Concentration of Acid-Extractable and Microwave-Digestible Uranium-238 in Sediments from Well 399-2-5 ................................................................................... 5.29

5.7 Concentration of Labile Uranium-238 in Sediments from Well 399-3-22 ............................. 5.32

5.8 Concentration of Water-Extractable Uranium-238 in Sediments from Well 399-4-14 ............. 5.40

5.9 Concentration of Acid-Extractable and Microwave-Digestible Uranium-238 in Sediments from Well 399-4-14 .................................................................................. 5.44

5.10 Concentration of Labile Uranium-238 in Sediments from Well 399-4-14 ............................ 5.46

5.11 Core Photographs of C4999-11D and C5000-39B …....................................................... 5.49

5.12 Distribution of Total U Concentration in Sediments from C4999 and C5000 Wells

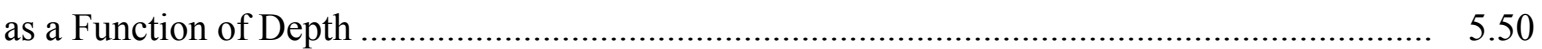

5.13 Labile U Concentration of Bicarbonate Extract for Sediment 11D and 39B ........................ 5.51

5.14 U Adsorption Isotherms for Two Sediments, Equilibrium Model Fits, and a Linear Isotherm Passing Through the Origin with Correlation Coefficient Value ............................... 5.52

5.15 U Concentrations Desorbed by SGW-2-Calcite and Model Fits with Equilibrium and Kinetic Model for Sediment 11D and 39B. 


\section{Tables}

1.1 Summary of LFI and VOC Investigation Drilling Information .......................................... 1.4

3.1 Summary of Sediment Samples Collected from Well 399-2-5 ........................................... 3.2

3.2 Summary of Sediment Samples Collected from Well 399-3-22 ............................................ 3.3

3.3 Summary of Sediment Samples Collected from Well 399-4-14 …........................................ 3.4

3.4 Groundwater Samples Analyzed by WSCF .................................................................. 3.8

4.1 Summary Information on Major Stratigraphic Units ......................................................... 4.2

5.1 Gravimetric Moisture Content of Samples Retrieved from Well 399-2-5 .............................. 5.2

$5.2 \mathrm{pH}$ for 1:1 Sediment:Water Extracts and Dilution-Corrected EC Values from Well 399-2-5.... 5.3

5.3 Water-Extractable Anions in Sediments from Well 399-2-5 ................................................ 5.4

5.4 Water-Extractable Major Cations in Sediments from Well 399-2-5 ....................................... 5.5

5.5 Water-Extractable Cations in Sediments from Well 399-2-5 ............................................... 5.5

5.6 Water-Extractable Uranium in Sediments from Well 399-2-5 .............................................. 5.6

$5.7 \mathrm{pH}$ and EC Data in UFA Extracts of Sediments from Well 399-2-5 ..................................... 5.8

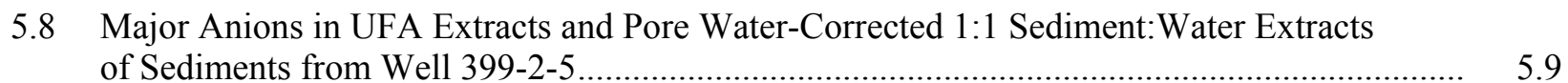

5.9 Major Cations in UFA Extracts and Pore Water-Corrected 1:1 Sediment:Water Extracts of Sediments from Well 399-2-5 ................................................................................. 5.10

5.10 Uranium Concentrations in UFA Extracts and Pore Water-Corrected 1:1 Sediment:Water Extracts of Sediments from Well 399-2-5 .................................................................... 5.11

5.11 Acid-Extractable and Microwave-Digestible Uranium in Sediments from Well 399-2-5 ......... 5.12

5.12 Equilibrium $\mathrm{K}_{\mathrm{d}}$ Based on Water-Extractable Versus Acid-Extractable or MicrowaveDigestible Uranium in Sediments from Well 399-2-5 ....................................................... 5.13

5.13 Labile Uranium Concentrations as a Function of Time in Sediments from Well 399-2-5 ........ 5.15

5.14 Equilibrium $\mathrm{K}_{\mathrm{d}}$ Based on Labile Uranium 28-Day Sample Versus Water-Extractable Uranium in Sediments from Well 399-2-5 ........................................................................ 5.16

5.15 Total, Inorganic, and Organic Carbon Content of Sediments from Well 399-2-5 …............... 5.17

5.16 Major Anions in Groundwater Samples from Well 399-2-5 ................................................ 5.17

5.17 Major Cations in Groundwater Samples from Well 399-2-5 ............................................... 5.18

5.18 Uranium Concentrations in Groundwater Samples from Well 399-2-5 ................................... 5.19

5.19 Gravimetric Moisture Content of Samples Retrieved from Well 399-3-22 ............................ 5.20

$5.20 \mathrm{pH}$ for 1:1 Sediment:Water Extracts and Dilution-Corrected EC Values from

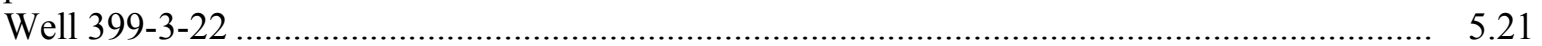

5.21 Water-Extractable Anions in Sediments from Well 399-3-22 _............................................. 5.22

5.22 Water-Extractable Major Cations in Sediments from Well 399-3-22 .................................... 5.22

5.23 Water-Extractable Cations in Sediments from Well 399-3-22 _............................................. 5.23

5.24 Water-Extractable Uranium in Sediments from Well 399-3-22 ............................................. 5.24

$5.25 \mathrm{pH}$ and EC Data in UFA Extracts of Sediments from Well 399-3-22 ................................... 5.25 
5.26 Major Anions in UFA Extracts and Pore Water-Corrected 1:1 Sediment:Water Extracts of Sediments from Well 399-3-22 .................................................................................. 5.26

5.27 Major Cations in UFA Extracts and Pore Water-Corrected 1:1 Sediment:Water Extracts of Sediments from Well 399-3-22 ...................................................................................... 5.27

5.28 Uranium Concentrations in UFA Extracts and Pore Water-Corrected 1:1 Sediment:Water Extracts of Sediments from Well 399-3-22 .................................................................. 5.28

5.29 Acid-Extractable and Microwave-Digestible Uranium in Sediments from Well 399-3-22 ....... 5.29

5.30 Equilibrium $\mathrm{K}_{\mathrm{d}}$ Based on Water-Extractable Versus Acid-Extractable or MicrowaveDigestible Uranium in Sediments from Well 399-3-22 ........................................................ 5.30

5.31 Labile Uranium Concentrations as a Function of Time in Sediments from Well 399-3-22 ....... 5.32

5.32 Equilibrium $\mathrm{K}_{\mathrm{d}}$ Based on Labile Uranium 28 Day Sample Versus Water-Extractable Uranium in Sediments from Well 399-3-22 .................................................................. 5.32

5.33 Total, Inorganic, and Organic Carbon Content of Sediments from Well 399-3-22 ................. 5.33

5.34 Major Anions in Groundwater Samples from Well 399-3-22 _............................................. 5.34

5.35 Major Cations in Groundwater Samples from Well 399-3-22 ............................................ 5.34

5.36 Uranium Concentrations in Groundwater Samples from Well 399-3-22 ............................... 5.35

5.37 Gravimetric Moisture Content of Samples Retrieved from Well 399-4-14 _........................... 5.36

$5.38 \mathrm{pH}$ for 1:1 Sediment:Water Extracts and Dilution-Corrected EC Values from

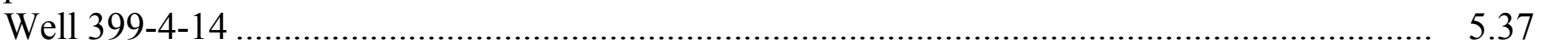

5.39 Water-Extractable Anions in Sediments from Well 399-4-14 _............................................. 5.38

5.40 Water-Extractable Major Cations in Sediments from Well 399-4-14 ..................................... 5.39

5.41 Water-Extractable Cations in Sediments from Well 399-4-14 ............................................... 5.39

5.42 Water-Extractable Uranium in Sediments from Well 399-4-14 .............................................. 5.40

$5.43 \mathrm{pH}$ and EC Data in UFA Extracts of Sediments from Well 399-4-14 .................................... 5.41

5.44 Major Anions in UFA Extracts and Pore Water-Corrected 1:1 Sediment:Water Extracts of Sediments from Well 399-4-14 ................................................................................ 5.42

5.45 Major Cations in UFA Extracts and Pore Water-Corrected 1:1 Sediment:Water Extracts of Sediments from Well 399-4-14................................................................................. 5.42

5.46 Uranium Concentrations in UFA Extracts and Pore Water-Corrected 1:1 Sediment:Water Extracts of Sediments from Well 399-4-14 ...................................................................... 5.43

5.47 Acid-Extractable and Microwave-Digestible Uranium in Sediments from Well 399-4-14....... 5.43

5.48 Equilibrium $\mathrm{K}_{\mathrm{d}}$ Based on Water-Extractable Versus Acid-Extractable or MicrowaveDigestible Uranium in Sediments from Well 399-4-14 ........................................................ 5.44

5.49 Labile Uranium Concentrations as a Function of Time in Sediments from Well 399-4-14 ...... 5.45

5.50 Equilibrium $\mathrm{K}_{\mathrm{d}}$ Based on Labile Uranium 28 Day Sample Versus Water-Extractable Uranium in Sediments from Well 399-4-14 ................................................................... 5.46

5.51 Total, Inorganic, and Organic Carbon Content of Sediments from Well 399-4-14 …............. 5.47

5.52 Major Anions in Groundwater Samples from Well 399-4-14 .............................................. 5.47

5.53 Major Cations in Groundwater Samples from Well 399-4-14 ............................................. 5.48

5.54 Uranium Concentrations in Groundwater Samples from Well 399-4-14 ................................ 5.49 


\subsection{Introduction}

The Hanford Site in southeastern Washington State was once home to weapons-grade plutonium production. Uranium processing and fuel fabrication processes were conducted from 1943 to 1988 in the 300 Area of the Hanford Site. As a result of these activities, numerous waste streams were discharged to cribs, ponds, and trenches near the 300 Area. Typical waste streams discharged to the environment included uranyl nitrate hexahydrate, ammonium nitrate, hexone, and neutralized waste acids containing metallic and chemical components of the fuel fabrication process, as well as process chemicals and solutions used in the numerous fuel reprocessing and separation techniques employed at Hanford (Gerber 1992). Total uranium inventories discharged to the environment in the 300 Area included $100 \mathrm{~kg}$ to cribs, $10,000 \mathrm{~kg}$ to process trenches, and as much as $60,000 \mathrm{~kg}$ to process ponds (Gerber 1992). Consequently, these activities contaminated sediments and groundwater near and beneath the 300 Area disposal facilities (cribs, trenches, and ponds) with significant amounts of uranium.

Over the last 15 years, the Hanford Site has shifted from production and operation to facility decommissioning and site remediation. Remedial action strategies in the 300 Area focused on removal of nearsurface uranium-contaminated sediment from the process ponds and trenches. Although this effort has resulted in the removal of several hundred thousand metric tons of sediment, uranium contamination continues to persist in groundwater beneath the 300 Area at concentrations greater than the current maximum contaminant level (MCL) (30 $\mu \mathrm{g} / \mathrm{L}$ ) for drinking water (Hartman et al. 2005, Peterson et al. 2005). This is particularly problematic because the Columbia River is a discharge point for 300 Area groundwater. To fully understand the long-term effect that residual uranium will have on the 300 Area groundwater system, the form and fate of residual uranium in the remaining sediments must first be determined.

Several characterization campaigns have been deployed in the 300 Area since 2001. The primary objectives of these efforts, which are discussed in more detail in Section 2, were to define inventories of contaminant uranium in the subsurface environment and to identify the mechanism(s) controlling the mobility (i.e., leaching and sorption) of uranium in the 300 Area. In addition to providing insight on the fate of contaminant uranium in the vadose zone, data from these studies were used to create a "box model" of the inventory of uranium in sediments and groundwater beneath the 300 Area (Peterson et al. 2008a). Results from the present characterization study provide valuable insight on the distribution of contaminant uranium in Hanford's 300 Area and will be used to refine the current source term conceptual model.

\subsection{Current 300 Area Characterization Activities}

In 2006, during a limited field investigation (LFI) involving uranium in the subsurface at the Hanford Site's 300 Area, unexpectedly high concentrations of volatile organic compounds (VOCs) were discovered in groundwater samples collected at two of the four characterization boreholes (Williams et al. 2007). The samples were obtained during drilling and came from a stratigraphic interval in the unconfined aquifer that is not monitored by the existing well network. The occurrences appeared to be restricted to an interval of relatively finer-grained sediment within the Ringold Formation. The VOC concentrations observed exceed the U.S. Environmental Protection Agency's (EPA) drinking water standards by as much as two orders of magnitude. 
In response to this discovery, a strategy to further characterize VOC contamination in the finergrained stratigraphic interval was developed, including additional drilling (Kooiker et al. 2007). The work involved drilling and characterization activities at four new locations near the initial discovery. The drilling was conducted between April and November 2007. Figure 1.1 is a monitoring site location map for the 300 Area and shows the characterization boreholes drilled as part of the LFI for uranium and the subsequent boreholes drilled as part of the VOC investigation. Before drilling the VOC wells during fiscal year 2007, funding was made available to collect "opportunistic" data on the distribution of uranium in sediments retrieved from three of the four VOC investigation boreholes. This report presents the new information obtained since the LFI characterization report (Williams et al. 2007) regarding uranium contamination beneath the 300 Area.

\subsection{Drilling and Characterization Methodology}

A cable-tool rig was used to drill the four VOC investigation boreholes (see Figure 1.1 for locations). The boreholes were situated in up- and downgradient groundwater flow directions from well 399-3-20, where the highest concentrations of trichloroethylene (TCE) were observed during the LFI. Drilling information associated with the VOC investigation boreholes is presented in Table 1.1 (information for the earlier LFI boreholes is included for completeness). Characterization activities conducted during drilling included geologic descriptions by the well-site geologist, collection of sediment and groundwater samples, depth-discrete aquifer hydraulic tests, and spectral gamma and neutron moisture geophysical logging. Rapid turnaround analyses for VOCs in groundwater samples collected during drilling were done to help with decisions on characterization while the borehole was proceeding, and also with the final design for completing each borehole as a groundwater monitoring well.

New borehole 399-3-21, which is adjacent to LFI borehole 399-3-20, was the first to be drilled. Its purpose was to confirm the elevated levels of TCE in the relatively finer-grained interval observed earlier within Ringold Formation Unit $\mathrm{E}$ and to further characterize the upper, previously undefined lower portions of the unconfined aquifer. (Note: LFI borehole 399-3-20 did not extend below the finer-grained interval). The borehole was subsequently completed as a monitoring well in the lower portion of the unconfined aquifer (i.e., below the finer-grained interval and near the contact with the top of the Ringold Formation lower mud unit), thus forming a shallow/deep unconfined aquifer monitoring well pair with adjacent well 399-3-20. Borehole 399-3-21 was not characterized as part of this study.

Three additional characterization boreholes were subsequently drilled in the vicinity of the 399-3-20 and 399-3-21 well pair. Borehole 399-2-5 was drilled next, approximately $230 \mathrm{~m}$ north-northwest of the well pair and within the footprint of the former South Process Pond (SPP). Borehole 399-4-14 was drilled about $250 \mathrm{~m}$ south of the well pair, and finally 399-3-22 was drilled about $175 \mathrm{~m}$ northwest of the well pair. The relatively finer-grained interval within Ringold Formation Unit E was encountered at all of these borehole locations; however, the lithologies encountered within the interval varied among the locations. 


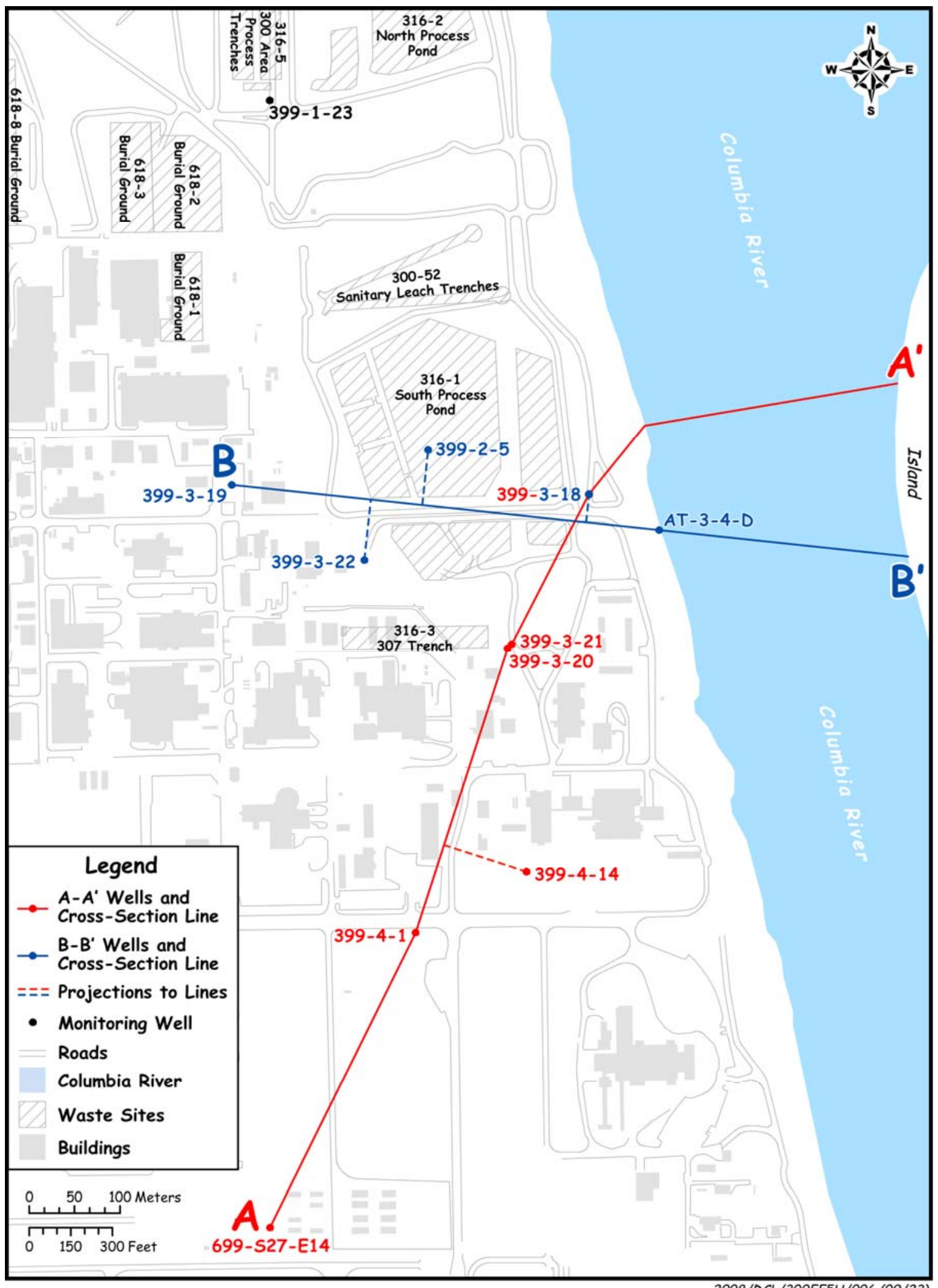

2008/DCL/300FF5U/006 (09/23)

Figure 1.1. Groundwater Monitoring Locations in the 300 Area 
Table 1.1. Summary of LFI and VOC Investigation Drilling Information

\begin{tabular}{|c|c|c|c|c|c|c|c|}
\hline $\begin{array}{l}\text { Well Name } \\
\text { (Well ID) }\end{array}$ & $\begin{array}{l}\text { Start Date } \\
\text { for } \\
\text { Drilling }\end{array}$ & $\begin{array}{l}\text { Finish } \\
\text { Date for } \\
\text { Drilling }\end{array}$ & $\begin{array}{l}\text { Northing }^{(a)} \\
(m)\end{array}$ & $\begin{array}{l}\text { Easting }^{(\mathrm{a})} \\
(\mathrm{m})\end{array}$ & $\begin{array}{l}\text { Ground } \\
\text { Surface }{ }^{(b)} \\
(m)\end{array}$ & $\begin{array}{c}\text { Total } \\
\text { Drill } \\
\text { Depth } \\
(\mathrm{m})\end{array}$ & $\begin{array}{l}\text { Completed } \\
\text { Well: } \\
\text { Screened } \\
\text { Interval }\end{array}$ \\
\hline \multicolumn{8}{|c|}{ Limited Field Investigation for Uranium (Williams et al. 2007) } \\
\hline $\begin{array}{c}399-3-18 \\
\text { (C4999) }\end{array}$ & $3 / 9 / 06$ & $3 / 23 / 06$ & $116,019.98$ & $594,464.71$ & 117.680 & 77.75 & Water table \\
\hline $\begin{array}{c}399-1-23 \\
(\mathrm{C} 5000)\end{array}$ & $3 / 30 / 06$ & $4 / 12 / 06$ & $116,453.04$ & $594,113.52$ & 115.446 & 75.52 & Water table \\
\hline $\begin{array}{c}399-3-19 \\
(5001)\end{array}$ & $4 / 24 / 06$ & $5 / 3 / 06$ & $116,030.22$ & $594,071.94$ & 120.647 & 80.72 & Water table \\
\hline $\begin{array}{c}399-3-20 \\
\text { (C5002) }\end{array}$ & $5 / 11 / 06$ & $5 / 16 / 06$ & $115,849.70$ & $594,375.42$ & 120.448 & 80.52 & Water table \\
\hline \multicolumn{8}{|c|}{ VOC Investigation (Horner 2008) } \\
\hline $\begin{array}{l}\text { 399-3-21 } \\
\text { (C5575) }\end{array}$ & $4 / 12 / 07$ & $5 / 15 / 07$ & $115,854.28$ & $594,379.75$ & 121.158 & 81.23 & $\begin{array}{l}\text { Lower part, } \\
\text { unconfined }\end{array}$ \\
\hline $\begin{array}{l}399-2-5 \\
(\mathrm{C} 5708)\end{array}$ & $9 / 4 / 07$ & $10 / 5 / 07$ & $116,068.80$ & $594,287.74$ & 115.705 & 75.78 & Water table \\
\hline $\begin{array}{c}399-4-14 \\
\text { (C5707) }\end{array}$ & $10 / 8 / 07$ & $10 / 29 / 07$ & $115,604.70$ & $594,396.18$ & 118.792 & 78.86 & Water table \\
\hline $\begin{array}{c}399-3-22 \\
\text { (C5706) }\end{array}$ & $10 / 31 / 07$ & $11 / 29 / 07$ & $115,947.53$ & $594,217.71$ & 119.241 & 79.31 & $\begin{array}{l}\text { Lower part, } \\
\text { unconfined }\end{array}$ \\
\hline
\end{tabular}

(a) Northing and easting coordinates are Washington State Plane, South Zone (NAD83 1991).

(b) Ground surface elevation and total drill depths are elevations (NAVD88 1988).

Grab samples collected from the core barrel drive shoe at approximately 5-ft depth intervals were used to describe these lithologies as they were encountered in the boreholes. Split-spoon core samples were also collected, although not continuously throughout each borehole. Split-spoon sampling included 10 cores from 399-2-5, 6 cores from 399-4-14, and 7 cores from 399-3-22. The field descriptions are recorded on the geologist's borehole logs, which are provided in a borehole summary report (Horner 2008, Appendixes A-K) and the Hanford Well Information System. The sediment samples provide visual confirmation of the relative depths and zonation (i.e., changes in lithology) for Hanford and Ringold formation stratigraphic units.

The grab sample and split-spoon core data help to form a detailed lithologic description of individual units, and to determine the hydrogeologic contact boundaries and unit thicknesses. The sample quality and formation representativeness of the sediment grab samples are generally good where complete recovery of cuttings occurred. Information from the discrete-depth core samples was used along with information from the continuous cores obtained earlier from the LFI boreholes to corroborate information developed from the more frequent sediment grab samples.

\subsection{Scope of Uranium Investigation}

As an opportunistic characterization activity, samples to be analyzed under the current effort were selected using a tiered approach. Under this approach, emphasis was placed on analyzing samples collected within the footprint of the 316-1 SPP (well 399-2-5), followed by samples from well 399-3-22, 
with the least priority placed on samples collected from well 399-4-14. Further, although all three of these boreholes were drilled to (or nearly to) the Ringold Formation Unit 8-Lower Mud (Figures 1.2 and 1.3), the majority of the samples selected for uranium characterization and analyses were collected within the Hanford formation and Undesignated Finer-Grained Unit (Figures 1.2 and 1.3). The rationale for this tiered approach was based on previous characterization efforts (Williams et al. 2007) that identified uranium contamination residing primarily within the unsaturated Hanford formation.

\subsection{Objectives of Uranium Investigation}

The primary objectives of this characterization activity were to 1) determine the extent of uranium contamination in the sediments, 2) quantify the leachable (labile) concentration of uranium in the sediments, and 3) create a data set that could be used to correlate the present data to existing 300 Area data. To meet these objectives, sediments collected from wells 399-2-5 (C5708), 399-3-22 (C5706), and 399-414 (C5707) were analyzed for moisture content, 1:1 sediment:water extracts (which provide soil $\mathrm{pH}$, electrical conductivity [EC], cation, and anion data), total carbon and inorganic carbon content, $8 \mathrm{M}$ nitric acid extracts (which provide a measure of the total leachable sediment content of the contaminants), microwave-assisted digestion (which results in total digestion of the sediment), and carbonate leaches (which provide an assessment of the concentration of labile uranium present in the sediments). Additionally, pore waters present in select samples were extracted using ultracentrifugation. Sampling preference was always biased toward the finer-grained and/or wetter material contained in each grab sample or core liner. Past characterization campaigns have shown that elevated concentrations of contaminants occur in sediment fractions characterized by higher water contents (Williams et al. 2007).

In addition to the aforementioned analyses, a summary of previous studies and existing data is presented in Section 2. This review and summary of prior characterization efforts has been included to facilitate data correlation with the present study and provide a basis for updating the source term conceptual model for contaminant uranium in the 300 Area. 


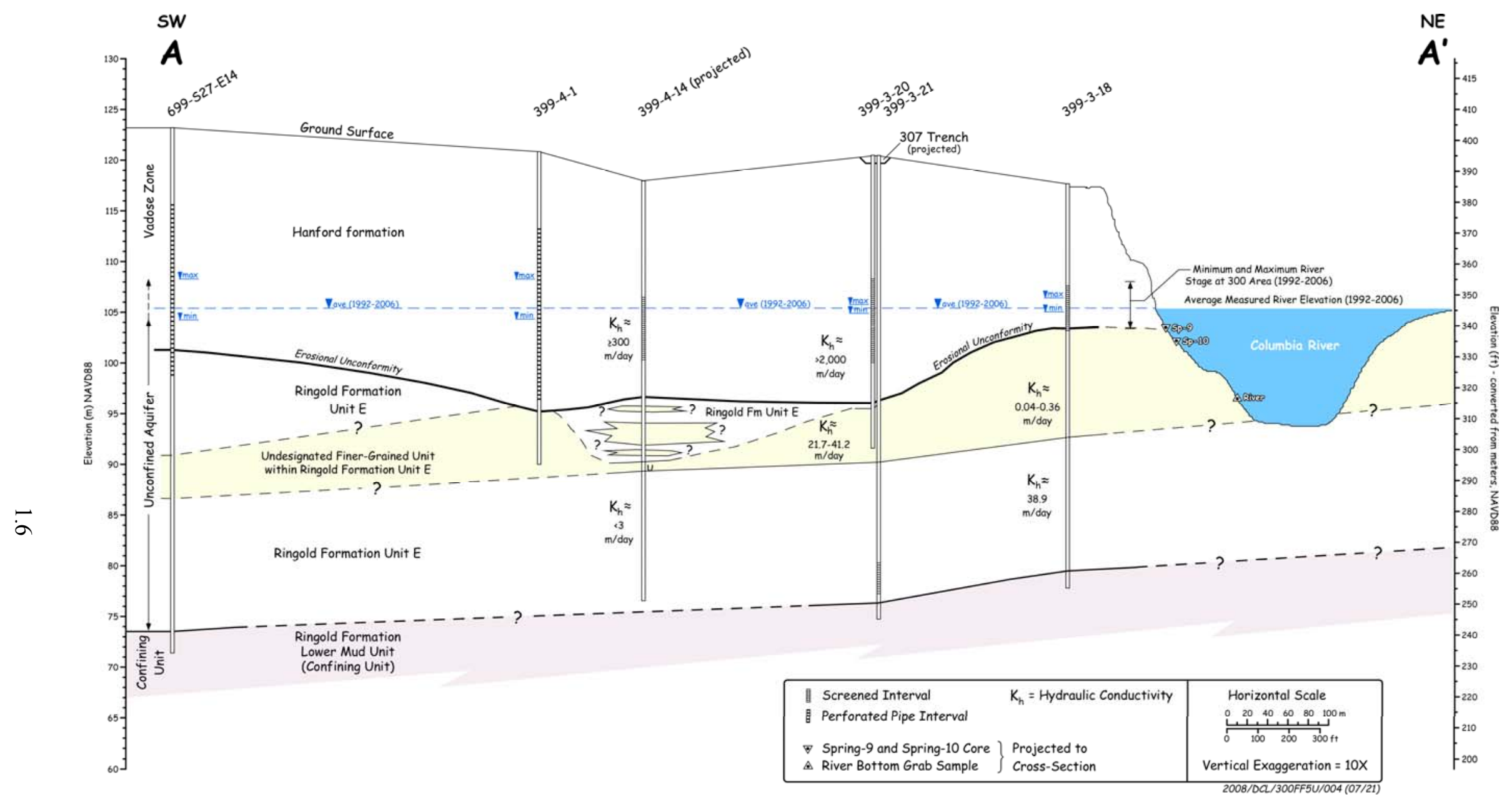

Figure 1.2. Cross Section Southwest to Northeast (A - A') Across the 300 Area 


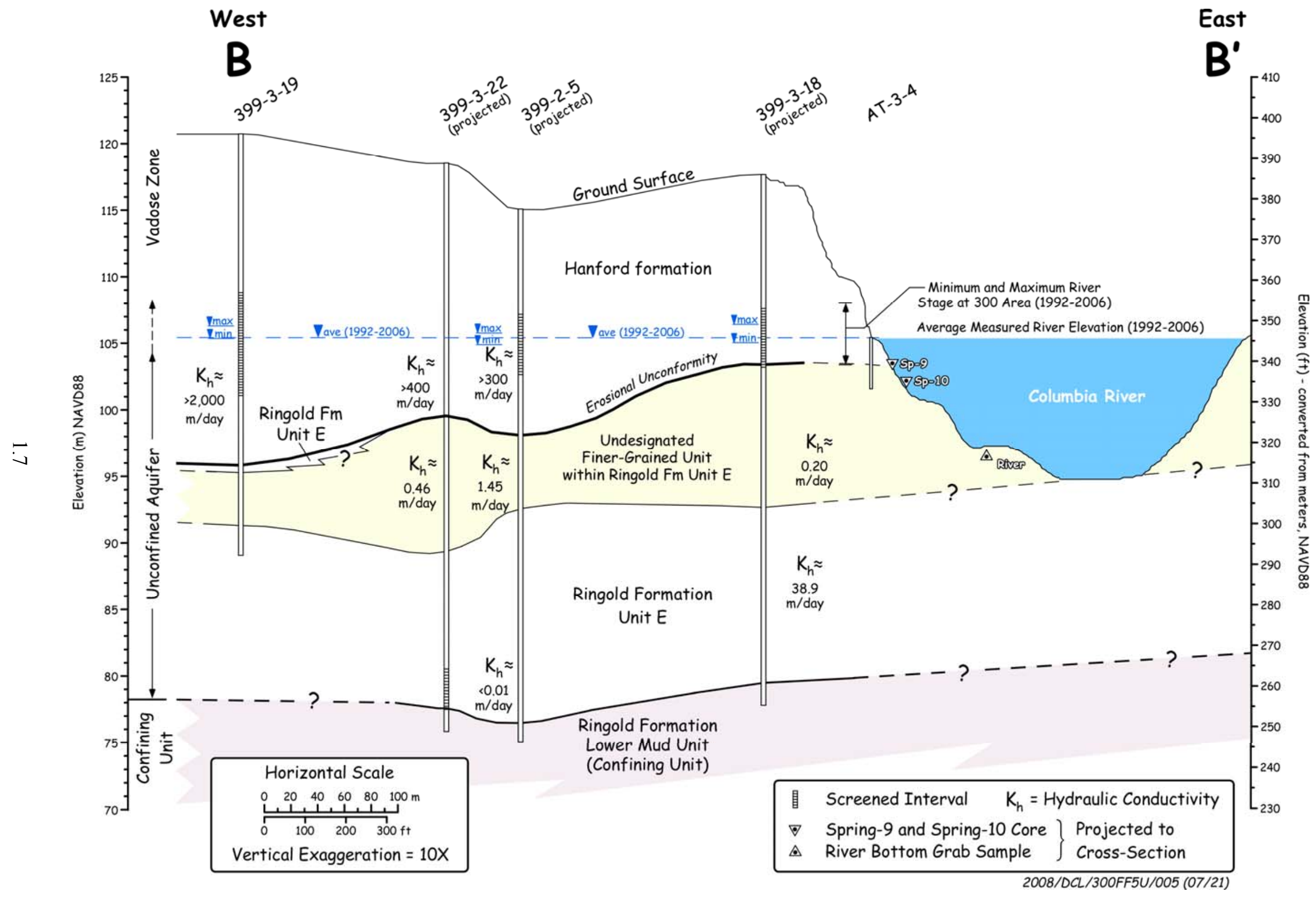

Figure 1.3. Cross Section West to East (B - B') Across the 300 Area 



\subsection{Previous Characterization Activities}

A significant effort has been expended over the last eight years in an attempt to understand the fate of uranium in the 300 Area vadose zone and groundwater system. Four important reports have been generated as part of these activities: Serne et al. (2002a), Zachara et al. (2005), Williams et al. (2007), and Peterson et al. (2008a). This section summarizes these reports and highlights their significant findings.

\subsection{Area Uranium Leach and Adsorption Project (Serne et al. 2002a)}

The objective of the 300 Area $K_{d} /$ leach study was to perform controlled laboratory experiments to measure the leaching and adsorption characteristics of uranium in near-surface sediment samples collected from the 300 Area of the Hanford Site. Specifically, eight near-surface sediment samples were collected by the Environmental Restoration Contractor between December 2000 and February 2001. The samples consisted of three uncontaminated background sediment samples (B11491, B11492, and B11493), two uranium-contaminated samples from the 300 Area North Process Pond (NPP) (B11494 and B11495), and three uranium-contaminated samples collected in the vicinity of the 303-K Building (B11BY4, B11BY5, and B11BY6).

Under this project, the sediment samples were subjected to a series of mineralogical and geochemical measurements. The samples were found to be composed primarily of coarse-grained sands with some gravel (sample B11494 contained slightly more silt and fine-grained material than all others). The organic carbon content of the samples was typical for Hanford soils $(<1 \%)$, with the exception of sample B11BY5, which contained almost $3 \%$ by weight organic carbon. Scanning electron micrographs of the 53 to $75 \mu \mathrm{m}$ and the $<53 \mu \mathrm{m}$ size fractions from sample B11BY6 showed that the uranium contamination in the sediments is most likely present as coprecipitates and/or discrete uranium particles. State-of-the-art molecular probe techniques also confirmed the presence of crystalline discrete uranium-bearing phases in the sediments from around the $303-\mathrm{K}$ Building. The nature of uranium in the sediments from the 300 Area NPP is less certain. One technique used on sample B11494 from the NPP indicated the presence of the same crystalline compounds that were found in samples from around the 303-K Building, but another technique indicated that the uranium in sample B11494 was less crystalline and predominately amorphous. In all cases, the uranium was present as oxidized uranium (uranyl [U(VI)]). Semi-selective extraction analysis of the near-surface sediment samples showed that the bulk of the extractable uranium in the contaminated sediments was associated with weak acid dissolvable phases (perhaps discrete uranyl compounds or associated with alkaline earth carbonates) and with amorphous hydrous iron and aluminum oxides, and that very little (a few percent or less) of the uranium was readily water soluble or ion exchangeable.

Results from large column leach tests showed that uranium leaching did not follow the expectations of a constant solubility paradigm. Four of the five near-surface sediments showed a large, nearly instantaneous release of a few percent of the total uranium in the first few pore volumes, followed by a slower, continual release that continued for many pore volumes (months). Steady-state uranium leachate concentrations were never attained, and leaching characteristics and trends were not consistent among the samples. Dissolution kinetics were slow, and the measured leach curves most likely represent a slow, 
kinetically controlled desorption or dissolution paradigm. Results from the preliminary column and batch adsorption experiments showed that uranium sorption onto the uncontaminated 300 Area Hanford formation sediment was highly variable and that sorption was dependent on the solution concentrations of inorganic carbon (i.e., bicarbonate-carbonate), $\mathrm{pH}$, and to a lesser extent, total dissolved solids.

Long-term static batch leach tests were used to investigate whether steady-state uranium concentrations could be attained and be used to determine a desorption $\mathrm{K}_{\mathrm{d}}$ for the slowly leaching fraction observed in the large-column leach tests. Aliquots of sediment taken from the large leach columns after they were stopped were subjected to three leaching solutions (deionized water, uncontaminated groundwater, and simulated vadose zone pore water) to determine how much of the recalcitrant uranium could be removed over a six-month period. Results from the batch leach test showed that less than $4 \%$ of the remaining uranium mass was removed by deionized water. The groundwater solution was slightly more effective, leaching as much as $10 \%$ of the recalcitrant uranium. The simulated vadose zone pore water solution was the most effective at leaching uranium, removing almost $30 \%$ of the residual total uranium mass in two out of the five contaminated samples.

Three batch adsorption experiments were performed to investigate the effect of uranium solution concentration, $\mathrm{pH}$, and dissolved inorganic carbon solution concentration on uranium adsorption onto the uncontaminated sediment. Uranium adsorption $\mathrm{K}_{\mathrm{d}}$ values ranged from 0 to more than $100 \mathrm{~mL} / \mathrm{g}$ depending on which solution parameter was being adjusted. Results of the batch adsorption experiments showed that total inorganic carbon solution concentration had the greatest effect on uranium adsorption onto the uncontaminated 300 Area sediment. Solution $\mathrm{pH}$ was shown to be important in laboratory tests; however, reactions between pore water and soil govern the $\mathrm{pH}$ (i.e., the $\mathrm{pH}$ is buffered to a nearly constant value), thus minimizing its overall effect in the 300 Area sediments. Results from the batch adsorption tests also showed that uranium sorption onto the uncontaminated sediment was linear up to uranium concentrations of $3 \mathrm{mg} / \mathrm{L}$ (holding all other parameters constant), which is well above the values found in the upper unconfined aquifer. Thus, the linear isotherm assumption holds for uranium in the 300 Area sediment/pore water environment. However, the natural vadose zone pore water and groundwater chemical compositions in the 300 Area are not constant. Carbonate, $\mathrm{pH}$, and other constituents vary in space and time because of evapotranspiration, transient rainfall/snow events, and the fluctuations of the Columbia River. River stage fluctuation causes groundwater and river water to mix at different proportions at different times of year and even at different times of day when the dam operations are affecting the river flow. Therefore, the $\mathrm{K}_{\mathrm{d}}$ for uranium(VI) is not a constant even though the adsorption of uranium(VI) from a fixed composition solution onto the uncontaminated sediment follows the linear isotherm.

Column adsorption tests were performed to assess the sorption, or loading, of uranium onto the background, or uncontaminated sediment. This test most closely predicts the fate of uranium contaminated solutions once they come into contact with "clean" or uncontaminated sediment. Uranium adsorption $\mathrm{K}_{\mathrm{d}}$ values ranged from $1.85 \mathrm{~mL} / \mathrm{g}$ in the low ionic-strength solution matrix to $0.86 \mathrm{~mL} / \mathrm{g}$ in the high ionic-strength solution matrix.

Less than $4 \%$ of the existing uranium in the contaminated near-surface sediments readily leached into "simulated" rainwater over a six-month period. Uranium sorption onto uncontaminated 300 Area sediment has been shown to be highly variable and to depend on solution conditions. Therefore, predicted $\mathrm{K}_{\mathrm{d}}$ values based on site-specific conditions expected in the 300 Area ranged from a low of 0 to $1 \mathrm{~mL} / \mathrm{g}$ in the near-surface vadose zone that is influenced by evapotranspiration to 2 to $4 \mathrm{~mL} / \mathrm{g}$ in the unconfined aquifer 
sediments not influenced by dilution with Columbia River water. Although not studied in detail, Serne et al. (2002a) predicted that adsorption $\mathrm{K}_{\mathrm{d}}$ values in the saturated aquifer, where dilution due to river water is present (lower total carbonate solution concentration), could be in excess of $7 \mathrm{~mL} / \mathrm{g}$.

\subsection{Uranium Geochemistry in Vadose Zone and Aquifer Sediments from the 300 Area Uranium Plume (Zachara et al. 2005)}

In June 2002, the U.S. Department of Energy (DOE) asked scientists at Pacific Northwest National Laboratory's (PNNL) Remediation and Closure Science Project to begin research on the 300 Area uranium plume, in collaboration with a small team of investigators from the Environmental Management Science Program, currently funded through the DOE Office of Biological and Environmental Research. The following are important conclusions and implications resulting from the project:

- Residual hexavalent uranium U(VI) concentrations observed beneath the NPP and SPP were variable and displayed no marked trend with depth. An average of $37.5 \%$ of the residual sorbed uranium was accessible to dissolution/desorption, but variation in this number between sediments was large. The magnitude of uranium release by dissolution or desorption was found to decrease with decreasing water content, and at $21 \%$ water saturation was only 1 to $3 \%$ total uranium.

- Both precipitated and adsorbed U(VI) existed in the sediments. A precise demarcation of precipitated and adsorbed forms and their relative concentrations was difficult, but it was concluded that adsorbed $\mathrm{U}(\mathrm{VI})$ predominates in sediments with total uranium $<25 \mathrm{ppm}$.

- The vadose zone sediments beneath the SPP and NPP remain as potential source terms to maintain groundwater U(VI) concentrations at or above the drinking water standard. Their ultimate impact will be controlled by moisture flux rates through the vadose zone and their bicarbonate concentrations. Increasing groundwater levels at high river stage will solubilize sorbed U(VI) from the capillary fringe and lower vadose zone.

- The extent of uranium adsorption decreases with increasing aqueous bicarbonate concentration. $\mathrm{U}(\mathrm{VI})$ is adsorbed by 300 Area vadose zone and aquifer sediments more strongly than previously recognized. Travel times for adsorption and desorption fronts through the aquifer will consequently be longer than previous estimates by factors of 2 to 5 or more.

- The intrusion of river water into the aquifer during periods of high river stage increases the adsorption of $\mathrm{U}(\mathrm{VI})$ to aquifer solids in regions of the saturated zone, where groundwater composition is controlled by river water chemistry. These mixing events slow the dissipation of the U(VI) groundwater plume and reduce the discharge of uranium from the 300 Area to the Columbia River.

- The vadose zone and aquifer sediments beneath the SPP and NPP differ significantly in sorption properties for uranium. A single value of $\mathrm{K}_{\mathrm{d}}$ is therefore unlikely to yield realistic simulations of $\mathrm{U}(\mathrm{VI})$ geochemical behavior in the 300 Area plume given heterogeneity in sediment properties and the apparent importance of kinetic processes.

- The dissolution of U(VI)-containing solids and desorption of U(VI) surface complexes in the contaminated sediments is slow. Equilibrium-based models do not capture the slow release and have led to underestimating the time required for plume dissipation to the maximum contaminant level. 


\subsection{Limited Field Investigation Report for Uranium Contamination in the 300-FF-5 Operable Unit at the 300 Area, Hanford Site, Washington (Williams et al. 2007)}

Additional data needed for developing a Comprehensive Environmental Response, Compensation, and Liability Act (CERCLA) Phase III feasibility study to address a persistent uranium plume in 300 Area groundwater provided the stimulus for the LFI. The focus of the LFI was to determine the location and geochemical nature of the source for the uranium plume. These objectives were addressed by drilling four new groundwater monitoring wells in the 300-FF-5 Operable Unit (OU) in fiscal year 2006. Wells 399-3-18 (C4999), 399-3-19 (C5001), 399-3-20 (C5002), and 399-1-23 (C5000) were drilled to characterize the uranium distribution in sediments in the vadose zone and the unconfined aquifer.

The four LFI borehole locations were chosen to represent various combinations of proximity to former waste disposal sites, proximity to the Columbia River, and wide-ranging hydrogeologic features. Highly detailed descriptions of geologic features encountered during drilling facilitated re-interpretation of descriptions from earlier drilling activities. Extensive analytical work was conducted on sediment samples collected from the continuous core recovered from each borehole and on water samples collected from the saturated zone at depth-discrete intervals during drilling. Hydrologic testing was conducted at multiple depth levels in each borehole to provide data on the ability of the sediment to transmit water. Geophysical logging of the entire borehole was conducted to provide additional details on stratigraphic features and attempt to identify and quantify contaminant uranium concentrations. In addition, new information was obtained on the unexpected presence of other contaminants of concern (e.g., volatile organic compounds [VOC]) at depths below those routinely monitored by the existing well network.

The LFI produced abundant new observational data about conditions in the vadose zone and unconfined aquifer that are relevant to uranium contamination in the subsurface environment. The new information developed during the LFI pertains to stratigraphy and hydrologic units, the vertical distribution of uranium in the vadose zone and unconfined aquifer, and the potential usefulness of geophysical logging for mapping contaminant uranium in future boreholes. Principal findings relative to the objectives of the LFI include the following:

- Geologic characterization activities performed during drilling have revealed significant new details on the stratigraphy at these sites. The new information allowed re-interpretation of drilling logs for previously installed wells, followed by a substantial update to the database for the hydrogeologic framework for the 300 Area. This update helps reduce uncertainty in computer simulation of groundwater flow and uranium transport through the aquifer.

- Lower-than-expected levels of contaminant uranium were encountered in the sediment samples from the vadose zone and were too low to permit use of spectral gamma geophysical logging in the field to define the vertical distribution of contaminant uranium in boreholes. Because of this, the planned Phase II drilling was canceled because it depended on using spectral gamma logging to map the distribution of contaminant uranium over a broad area.

- At three of the four borehole locations, there was no distinct evidence from laboratory geochemical analysis of samples collected during drilling and/or geophysical logging of relatively elevated levels of uranium in sediment immediately above the water table. At the fourth location, 399-1-23 (C5000), which is near the most recently active waste disposal site, somewhat elevated levels of uranium are indicated in the lower portion of the vadose zone. Elevated levels of contamination in this "smear 
zone" near the water table have been postulated as a source region that continues to supply uranium to the groundwater plume.

- Relatively high concentrations of uranium have been estimated for moisture associated with the unsaturated sediment above the water table in two of the four boreholes drilled (399-3-18 and 399-1-23). The estimates are based on the amount of uranium measured in 1:1 water extracts of sediment samples. These results were then adjusted so that they represent the concentrations present in the natural moisture associated with the sediment, as estimated using the lab sample.

- Contaminant uranium extracted from aquifer sediment samples was also at relatively low levels and comparable to levels observed in samples from the vadose zone.

- Total uranium concentrations in depth-discrete groundwater samples collected during drilling were generally consistent with those observed in historical groundwater monitoring results.

- The discrete interval groundwater sampling, laboratory geochemical extracts of the sediments, and hydraulic conductivity measurements conducted during drilling confirmed that the groundwater uranium plume is constrained above the Hanford-Ringold contact boundary. These data were consistent with groundwater uranium concentrations obtained from the current 300 Area monitoring well network.

\subsection{Uranium Contamination in the Subsurface Beneath the 300 Area, Hanford Site, Washington (Peterson et al. 2008a)}

Peterson et al. (2008a) estimate that approximately $650,000 \mathrm{~m}^{3}$ of groundwater beneath the 300 Area are affected by uranium at concentrations that exceed the drinking water standard of $30 \mu \mathrm{g} / \mathrm{L}$. The mass of uranium in that groundwater volume is estimated to vary within the approximate range of 45 to $77 \mathrm{~kg}$. The uranium plume is primarily contained within saturated sediment of the Hanford gravels formation, a highly permeable hydrologic unit. The level of contamination has remained relatively constant in recent years in spite of surface waste site source removal actions, groundwater plume discharge to the Columbia River, and withdrawal of groundwater at a water supply well. Concentrations of uranium in the groundwater plume vary seasonally in terms of maximum observed values as well as distribution pattern. Concentrations typically range from natural background levels $(<10 \mu \mathrm{g} / \mathrm{L})$ up to $\sim 200 \mu \mathrm{g} / \mathrm{L}$.

The groundwater uranium plume is discharged to the Columbia River primarily by upwelling through the riverbed, with an estimated areal extent of $\sim 0.17 \mathrm{~km}^{2}$. More limited discharge also occurs via several riverbank springs, where concentrations are similar to those observed at near-river wells. Estimates for uranium flux to the river via groundwater discharge indicate a rate of up to $200 \mathrm{~kg} / \mathrm{yr}$. However, uranium concentrations in near-shore river water in areas adjacent to plume discharge (water depths $\sim 1 \mathrm{~m}$ or less) during recent years range from 0.5 to $1.7 \mu \mathrm{g} / \mathrm{L}$, revealing the mitigating effects of contaminant dilution through mixing with river water.

The mobility characteristics of uranium vary within the multiple subsurface zones that contain residual contaminant uranium. Principal subsurface zones include 1) the vadose zone, 2) a zone through which the water table rises and falls, 3) the aquifer, and 4) a zone where groundwater and river water mix beneath the river shoreline. Principal controls on mobilization include the form of the residual uranium (e.g., crystalline minerals, amorphous precipitates/coatings sorbed onto sediment), the transporting medium (e.g., water infiltration from the land surface, groundwater), and the rate of exchange between the 
form and transporting medium. The bicarbonate content of aqueous media strongly influences the rate of exchange, with relatively higher dissolved bicarbonate content, enhancing uranium mobility. Groundwater has higher bicarbonate content than river water or other freshwater sources, such as utility and potable water systems.

The inventory of contaminant uranium that continues to supply the groundwater plume may be stored in several potential subsurface "compartments" defined for the various zones listed above. Of the 10 compartments evaluated, the largest inventory is for the vadose zone beneath former liquid waste disposal sites, while the second largest compartment is in the zone beneath waste sites through which the water table rises and falls. The former compartment is a less likely current contributor to groundwater contamination because of the relatively more-resistant form of the uranium and the low moisture flux in that compartment. The latter zone is a more likely current contributor because of periodic saturation by groundwater and a possibly less retentive form of uranium being present in the intermittently wetted sediment. The inventory of uranium in the aquifer, in dissolved and sorbed forms, is estimated to represent $\sim 5 \%$ of the total inventory calculated for the 10 compartments. A summary of the inventory analysis by compartment is shown in Figure 2.1.

The variety of processes affecting the mobility of uranium in the subsurface, along with the numerous potential compartments where residual contamination may be located, presents challenges for predicting uranium movement through the sedimentary matrix. The processes responsible for the persistence of the plume may involve cycling of uranium between the aquifer and overlying zone through which the water table fluctuates. Contaminated groundwater is moved upward into the lower vadose zone, and when the water table subsequently falls, contaminated moisture is left behind. Some of the uranium in groundwater may become sorbed to sediment in that zone and to subsequently slowly release. Also, near the Columbia River in the zone of groundwater/river water interaction, where the bicarbonate content is lowered because of dilution by infiltrating river water, the tendency for uranium to adsorb onto sediment is enhanced, thus slowing dissipation via the groundwater pathway. Fluctuations in the Columbia River stage are the driving mechanism for the rise and fall of the water table beneath the 300 Area and for creating the dynamic hydraulic and geochemical environment in the zone of interaction beneath the shoreline. 


\section{Estimated Uranium Inventory and Exchange Paths Among Subsurface Compartments Beneath the 300 Area}

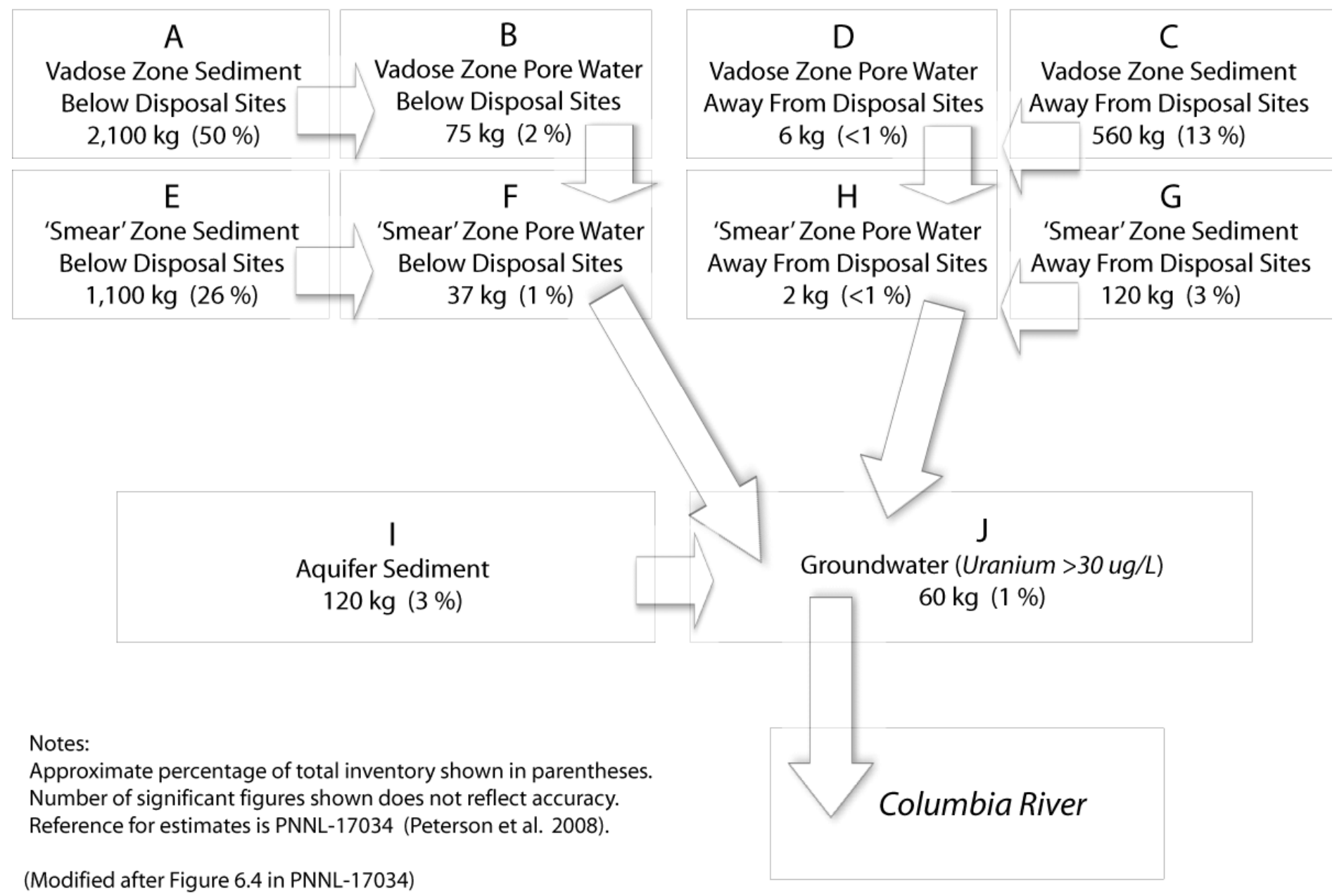

Figure 2.1. Uranium Inventory in Various Compartments in the 300 Area Subsurface 



\subsection{Materials and Methods}

This section discusses the methods and philosophy used to characterize the sediments collected from the VOC wells and the parameters that were measured and analyzed in the laboratory. It also describes the materials and methods used to conduct analyses of the physical, geochemical, and radio-analytical properties of the sediments.

\subsection{Sample Inventory}

Samples were numbered using Hanford Environmental Information System (HEIS)-specific sample names. The core samples from each sample interval were further identified by the numbers $1,2,3$, or 4 , where the number 1 liner was always in the deepest position closest to the drive shoe. One laboratory duplicate sample was collected during core opening; this sample was designated "DUP."

\subsubsection{Well 399-2-5 (Borehole C5708)}

Thirty-six core samples were received from the drilling of well 399-2-5. In addition, six moisture tin samples and two grab samples (labeled using borehole number and depth) were collected as part of the characterization campaign. Details about the core and grab samples received from well 399-2-5 are listed in Table 3.1.

\subsubsection{Well 399-3-22 (Borehole C5706)}

Twenty-five core samples were received from the drilling of well 399-3-22. Six additional moisture tin samples were received as part of this characterization campaign. Details about the core and grab samples received from well 399-3-22 are listed in Table 3.2.

\subsubsection{Well 399-4-14 (Borehole C5707)}

Eighteen core samples were received from the drilling of well 399-4-14. Additionally, nine moisture tin samples and one grab sample (labeled using borehole number and depth) were collected as part of this characterization campaign. Details about the core and grab samples received from well 399-4-14 are listed in Table 3.3. 
Table 3.1. Summary of Sediment Samples Collected from Well 399-2-5

\begin{tabular}{|c|c|c|}
\hline $\begin{array}{l}\text { Sample Name } \\
\text { (HEIS ID) }\end{array}$ & 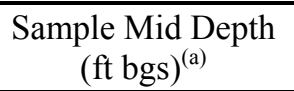 & Sample Type \\
\hline B1PL45-4 & 4.8 & Split Spoon Liner \\
\hline B1PL45-3 & 5.4 & Split Spoon Liner \\
\hline B1PL45-2 & 6.1 & Split Spoon Liner \\
\hline B1PL45-1 & 6.7 & Split Spoon Liner \\
\hline B1PL27 & 10.0 & Moisture Tin \\
\hline B1PL46-4 & 15.3 & Split Spoon Liner \\
\hline B1PL46-3 & 15.8 & Split Spoon Liner \\
\hline B1PL46-2 & 16.3 & Split Spoon Liner \\
\hline B1PL46-1 & 16.8 & Split Spoon Liner \\
\hline B1PL46-1 DUP & 16.8 & Duplicate Sample \\
\hline B1PL28 & 16.8 & Moisture Tin \\
\hline B1PL47-3 & 20.4 & Split Spoon Liner \\
\hline B1PL47-2 & 21.3 & Split Spoon Liner \\
\hline B1PL47-1 & 22.1 & Split Spoon Liner \\
\hline B1PL29 & 22.1 & Moisture Tin \\
\hline B1PL48-4 & 23.9 & Split Spoon Liner \\
\hline B1PL48-3 & 24.8 & Split Spoon Liner \\
\hline B1PL48-2 & 25.7 & Split Spoon Liner \\
\hline B1PL48-1 & 26.6 & Split Spoon Liner \\
\hline B1PL30 & 26.8 & Moisture Tin \\
\hline B1PL49-4 & 28.3 & Split Spoon Liner \\
\hline B1PL49-3 & 28.9 & Split Spoon Liner \\
\hline B1PL49-2 & 29.6 & Split Spoon Liner \\
\hline B1PL49-1 & 30.2 & Split Spoon Liner \\
\hline B1PL31 & 30 & Moisture Tin \\
\hline B1PL50-3 & 34.3 & Split Spoon Liner \\
\hline B1PL50-2 & 35.3 & Split Spoon Liner \\
\hline B1PL50-1 & 36.3 & Split Spoon Liner \\
\hline B1PL32 & 36.3 & Moisture Tin \\
\hline B1PL51-3 & 41.3 & Split Spoon Liner \\
\hline B1PL51-2 & 42.3 & Split Spoon Liner \\
\hline B1PL51-1 & 43.3 & Split Spoon Liner \\
\hline B1PL52-4 & 44.8 & Split Spoon Liner \\
\hline B1PL52-3 & 45.5 & Split Spoon Liner \\
\hline B1PL52-2 & 46.3 & Split Spoon Liner \\
\hline B1PL52-1 & 47.0 & Split Spoon Liner \\
\hline B1PL53-3 & 50.0 & Split Spoon Liner \\
\hline B1PL53-2 & 51.0 & Split Spoon Liner \\
\hline B1PL53-1 & 52.0 & Split Spoon Liner \\
\hline C5708-56.5 & 56.5 & Grab \\
\hline C5708-67 & 67.0 & Grab \\
\hline B1PL54-4 & 73.3 & Split Spoon Liner \\
\hline B1PL54-3 & 73.8 & Split Spoon Liner \\
\hline B1PL54-2 & 74.3 & Split Spoon Liner \\
\hline B1PL54-1 & 74.8 & Split Spoon Liner \\
\hline
\end{tabular}


Table 3.2. Summary of Sediment Samples Collected from Well 399-3-22

\begin{tabular}{ccc}
\hline $\begin{array}{c}\text { Sample Name } \\
\text { (HEIS ID) }\end{array}$ & $\begin{array}{c}\text { Sample Mid Depth } \\
\text { (ft bgs) }\end{array}$ & $\begin{array}{c}\text { Sample } \\
\text { Type }\end{array}$ \\
\hline B1PL33 & 9.5 & Moisture Tin \\
B1PL34 & 15.0 & Moisture Tin \\
B1PL35 & 20.0 & Moisture Tin \\
B1PL36 & 24.0 & Moisture Tin \\
B1PL37 & 30.0 & Moisture Tin \\
B1PL38 & 35.0 & Moisture Tin \\
B1PL55-4 & 37.3 & Split Spoon Liner \\
B1PL55-3 & 37.8 & Split Spoon Liner \\
B1PL55-2 & 38.3 & Split Spoon Liner \\
B1PL55-1 & 38.8 & Split Spoon Liner \\
B1PL56-4 & 39.9 & Split Spoon Liner \\
B1PL56-3 & 40.6 & Split Spoon Liner \\
B1PL56-2 & 41.4 & Split Spoon Liner \\
B1PL56-1 & 42.1 & Split Spoon Liner \\
B1PL57-4 & 42.9 & Split Spoon Liner \\
B1PL57-3 & 43.3 & Split Spoon Liner \\
B1PL57-2 & 43.6 & Split Spoon Liner \\
B1PL57-1 & 44.0 & Split Spoon Liner \\
B1PL58-4 & 55.9 & Split Spoon Liner \\
B1PL58-3 & 56.6 & Split Spoon Liner \\
B1PL58-2 & 57.4 & Split Spoon Liner \\
B1PL58-1 & 58.1 & Split Spoon Liner \\
B1PL59-4 & 62.8 & Split Spoon Liner \\
B1PL59-3 & 63.4 & Split Spoon Liner \\
B1PL59-2 & 64.1 & Split Spoon Liner \\
B1PL59-1 & 64.7 & Split Spoon Liner \\
B1PL60-4 & 65.6 & Split Spoon Liner \\
B1PL60-3 & 66.2 & Split Spoon Liner \\
B1PL60-2 & 66.9 & Split Spoon Liner \\
B1PL60-1 & 67.5 & Split Spoon Liner \\
B1PL61-4 & 81.8 & Split Spoon Liner \\
B1PL61-3 & 82.4 & Split Spoon Liner \\
B1PL61-2 & 83.1 & Split Spoon Liner \\
B1PL61-1 & 83.7 & Split Spoon Liner \\
B1PL61-1 DUP & 83.7 & Duplicate Sample \\
\hline & &
\end{tabular}


Table 3.3. Summary of Sediment Samples Collected from Well 399-4-14

\begin{tabular}{ccc}
\hline $\begin{array}{c}\text { Sample Name } \\
\text { (HEIS ID) }\end{array}$ & $\begin{array}{c}\text { Sample Mid Depth } \\
\text { (ft bgs) }\end{array}$ & $\begin{array}{c}\text { Sample } \\
\text { Type }\end{array}$ \\
\hline B1PL39 & 10.0 & Moisture Tin \\
B1PL40 & 15.0 & Moisture Tin \\
B1PL41 & 20.0 & Moisture Tin \\
B1PL42 & 25.0 & Moisture Tin \\
B1PL43 & 27.0 & Moisture Tin \\
B1PL62-4 & 28.4 & Split Spoon Liner \\
B1PL62-3 & 29.2 & Split Spoon Liner \\
B1PL62-2 & 29.9 & Split Spoon Liner \\
B1PL62-1 & 30.6 & Split Spoon Liner \\
B1PL44 & 31.0 & Moisture Tin \\
B1PL63-4 & 31.5 & Split Spoon Liner \\
B1PL63-3 & 32.5 & Split Spoon Liner \\
B1PL63-2 & 33.5 & Split Spoon Liner \\
B1R086 & 34.0 & Moisture Tin \\
B1PL64-4 & 34.5 & Split Spoon Liner \\
B1PL64-3 & 35.5 & Split Spoon Liner \\
B1PL64-2 & 36.5 & Split Spoon Liner \\
B1R087 & 37.0 & Moisture Tin \\
B1PL65-4 & 39.5 & Split Spoon Liner \\
B1PL65-3 & 40.5 & Split Spoon Liner \\
B1PL65-2 & 41.5 & Split Spoon Liner \\
B1R088 & 42.0 & Moisture Tin \\
B1R089 & 44.5 & Split Spoon Liner \\
C5707-43 & 43.0 & Grab \\
B1PL66-4 & 78.8 & Split Spoon Liner \\
B1PL66-3 & 79.5 & Split Spoon Liner \\
B1PL66-2 & 80.2 & Split Spoon Liner \\
B1PL66-1 & 80.8 & Split Spoon Liner \\
\hline & &
\end{tabular}

\subsection{Analytical Procedures and Methods}

During subsampling, every effort was made to minimize moisture loss and prevent crosscontamination between samples. Depending on the sample matrix, very coarse pebbles and larger material (i.e., $>32 \mathrm{~mm}$ ) were removed during sub-sampling. Before processing the sediments, all of the samples (except those taken through the moisture content of UFA extraction procedures) were air-dried and passed through a \#10 sieve to remove any material larger than $2 \mathrm{~mm}$ in diameter. This step was performed to create a data set that would be easier to correlate to existing data collected on sieved sediments. Thus the results from the subsample measurements may contain a possible bias toward higher concentrations for some analytes that would be preferentially associated with the smaller sized sediment fractions.

Procedures ASTM D2488-93 (1993) and PNL-MA-567-DO-1 (PNL 1990) were followed for visual descriptions and geological descriptions of all samples. The sediment classification scheme used for geologic identification of the sediment types (used solely for graphing purposes in this report) was based on the modified Folk/Wentworth classification scheme (1968/1922). 


\subsubsection{Moisture Content}

Gravimetric water contents of the sediment samples were determined using PNNL procedure PNNL-AGG-WC-001 (PNNL 2005), which is based on the American Society for Testing and Materials (ASTM) procedure, "Test Method for Laboratory Determination of Water (Moisture) Content of Soil and Rock by Mass" (ASTM D2216-98) (ASTM 1998). One representative subsample of at least 15 to $70 \mathrm{~g}$ was used. Sediment aliquots were placed in tared containers, weighed, and dried in an oven at $105^{\circ} \mathrm{C}$ until a constant weight was achieved, which took at least 24 hours. The containers were removed from the oven, sealed, cooled, and then weighed at least twice to ensure that all moisture was removed. All weighings were performed using a calibrated balance. A calibrated weight set was used to verify balance performance before weighing the samples. The gravimetric water content was computed as the percentage change in soil weight before and after oven drying.

\subsubsection{1:1 Sediment:Water Extracts}

Water-soluble inorganic constituents were determined using a 1:1 sediment:deionized-water extract method. The extracts were prepared by adding an equal weight of deionized water to approximately 60 to $80 \mathrm{~g}$ of sediment (post air-drying and sieving). The weight of deionized water needed was calculated based on the weight of the air-dried samples (residual moisture in the air-dried samples was considered negligible). An appropriate amount of deionized water was added to screw cap jars containing the sediment samples. The jars were sealed and briefly shaken by hand, then placed on a mechanical orbital shaker for one hour. The samples were allowed to settle overnight until the supernatant liquid was fairly clear. The supernatant was carefully decanted, filtered (passed through $0.45 \mu \mathrm{m}$ membranes), and analyzed for conductivity, $\mathrm{pH}$, anions, cations, alkalinity, and radionuclide analyses. More details can be found in Rhoades (1996) and "Methods of Soils Analysis," Part 3 (ASA 1996).

\subsubsection{1 pH and Conductivity}

Two aliquots of approximately 3-mL volume of the 1:1 sediment:water extract supernatants were used for $\mathrm{pH}$ and conductivity measurements. The $\mathrm{pH}$ of the extracts was measured within 24 hours of sampling using a solid-state $\mathrm{pH}$ electrode and a $\mathrm{pH}$ meter calibrated with buffers 7 and 10 . Electrical conductivity was measured and compared to potassium chloride standards with a range of 0.001 to $1.0 \mathrm{M}$.

\subsubsection{Anions}

The 1:1 sediment:water extracts were analyzed for anions using ion chromatography (IC). Fluoride, chloride, nitrite, bromide, nitrate, carbonate, phosphate, and sulfate were separated on a Dionex AS17 column with a gradient elution of $1 \mathrm{mM}$ to $35 \mathrm{mM}$ sodium hydroxide and measured using a conductivity detector. This methodology is based on EPA Method 300.0A (EPA 1984) with the exception of using the gradient elution of sodium hydroxide.

\subsubsection{Alkalinity}

The alkalinity of the 1:1 sediment:water extracts was measured using standard titration. The alkalinity procedure is equivalent to the U.S. Geological Survey (USGS) National Field Manual (USGS 2001) method. 


\subsection{3 $8 \mathrm{M}$ Nitric Acid Extract}

Approximately $20 \mathrm{~g}$ of air-dried sediment was contacted with $8 \mathrm{M}$ nitric acid at a ratio of approximately 3.5 parts acid to one part sediment. The slurries were heated to about $95^{\circ} \mathrm{C}$ for several hours, after which the fluid was separated by filtration through $0.45 \mu \mathrm{m}$ membranes. The acid extracts were analyzed for major cations and trace metals using ICP-OES and ICP-MS techniques, respectively. The acid digestion procedure is based on EPA SW-846 Method 3050B (EPA 2000).

\subsubsection{Microwave-Assisted Sample Digestion}

Using this technique, approximately $300 \mathrm{mg}$ of the air-dried sediments were placed in 100 -mL Teflon microwave digestion vessels. Following this, $10 \mathrm{~mL}$ water, $5 \mathrm{~mL}$ of $16-\mathrm{M}$ nitric acid $\left(\mathrm{HNO}_{3}\right), 2 \mathrm{~mL}$ of 12-M hydrochloric acid ( $\mathrm{HCl}$ ), and $1 \mathrm{~mL}$ of 29-M hydrofluoric acid (HF) were added, and the vessels were sealed and placed in a CEM MARS5 ${ }^{\mathrm{TM}}$ microwave-assisted digestion system. The samples were heated at the EPA-recommended temperatures and times (EPA 1996). The samples were then allowed to cool, and $0.45 \mathrm{~g}$ of powdered boric acid was added to the digestate and shaken by hand. Boric acid reacts with residual $\mathrm{HF}$ in the digestate to form a boron complex, preventing the residual HF from etching the sample introduction glassware in the ICP-MS analytical system. Although there were no visible solids in the digestate, samples were filtered through a $0.45-\mu \mathrm{m}$-pore-size syringe filter prior to analysis.

\subsubsection{Labile Uranium Leaching Using Sodium (Bi) Carbonate Solution}

The concentration of labile (easily removable fraction, such as ion exchangeable or water soluble) uranium in the air-dried sediments was measured using a sodium bicarbonate/carbonate mixed solution $\left(1.44 \times 10^{-2} \mathrm{M}\right.$ in $\mathrm{NaHCO}_{3}$ and $2.8 \times 10^{-3} \mathrm{M}$ in $\left.\mathrm{Na}_{2} \mathrm{CO}_{3}\right)$. The reagent $\mathrm{pH}$ was 9.3 and a solid-to-solution ratio of $50 \mathrm{~g} / \mathrm{L}$ was used for uranium leaching. The leached uranium concentration was determined as a function of time ranging from 1 to 28 days. Extract solutions were filtered using $0.45 \mu \mathrm{m}$ syringe filters and analyzed for uranium using ICP-MS. The solid-to-solution ratio was kept constant at $50 \mathrm{~g} / \mathrm{L}$ by adding fresh reagent to replace the small aliquot $(5 \mathrm{~mL})$ removed at each sampling time. This procedure is described in Kohler et al. (2004).

\subsubsection{Pore Water Composition}

Several field-moist sediments were packed in drainable cells that were inserted into an ultracentrifuge. The samples were centrifuged for up to 8 hours at several thousand g's to separate the pore water out of the sediment. The pore waters were characterized for $\mathrm{pH}$, electrical conductivity, cation, trace metals, selected radionuclide and anions using the same techniques as used for the 1:1 sediment-to-water extracts.

\subsubsection{Total and Inorganic Carbon Content}

The total carbon concentration in aliquots of air-dried sediment was measured with a Shimadzu TOC-V CSN instrument with an SSM-5000A Total Organic Carbon Analyzer by combustion at approximately $900^{\circ} \mathrm{C}$ based on ASTM method, "Standard Test Methods for Analysis of Metal Bearing Ores and Related Materials by Combustion Infrared Absorption Spectrometry" (ASTM E1915-01 2001). Samples were placed into precombusted, tared, ceramic combustion sample holders and weighed on a calibrated balance. After the combustion sample holders were placed into the furnace introduction tube, 
an approximately 2-minute waiting period was allowed for the ultra-pure oxygen carrier gas to remove any carbon dioxide introduced to the system from the atmosphere during sample placement. After this sparging process, the sample was moved into the furnace and the combustion process was begun. The carrier gas then delivered the sample combustion products to the cell of a non-dispersive infrared (NDIR) gas analyzer where carbon dioxide was detected and measured. The amount of $\mathrm{CO}_{2}$ measured is proportional to the total carbon content of the sample. System performance was confirmed by analyzing known quantities of a calcium carbonate standard.

Sediment samples were analyzed for inorganic carbon content by placing an aliquot of sediment into a ceramic combustion boat. The combustion boat was placed into the sample introduction tube where it was sparged with ultra-pure oxygen for two minutes to remove atmospheric carbon dioxide. A small amount (usually $0.6 \mathrm{~mL}$ ) of $3 \mathrm{M}$ phosphoric acid was then added to the sample in the combustion boat. The boat was moved into the combustion furnace, where it was heated to $200^{\circ} \mathrm{C}$. Samples were completely covered by the acid to allow full reaction to occur. Ultra-pure oxygen swept the resulting carbon dioxide through a dehumidifier and scrubber into the cell of a nondispersive infrared (NDIR) gas analyzer where the carbon dioxide was detected and measured. The amount of $\mathrm{CO}_{2}$ measured is proportional to the inorganic carbon content of the sample. Organic carbon content was determined by the difference between the inorganic carbon and total carbon concentrations.

\subsection{Additional Characterization Activities}

\subsubsection{Groundwater Analyses}

Several depth-discrete groundwater samples were collected during drilling of the VOC boreholes. Although the samples were analyzed by the Waste Sampling and Characterization Facility (WSCF) using their own procedures and methods, results of those analyses will be presented in this report to aid in data interpretation. Analyses performed on the groundwater samples include major anions, cations, and uranium-238. A list of the groundwater samples analyzed by WSCF is presented in Table 3.4; the information is segregated by well as a function of depth.

\subsubsection{Repetitive Washing and U(VI) Adsorption Isotherm}

Because high U(VI) concentrations were observed in sediments at depths close to the water table [41.5 and $23.1 \mathrm{ft}(12.7$ and $7.01 \mathrm{~m})$ bgs for sediments C4999-11D and C5000-39B, respectively] from the 300-FF-5 LFI wells [399-3-18 (C4999) and 399-1-23 (C5000)], core sediments (11D and 39B) from two of the four recent 300-FF-5 LFI wells were used for U(VI) batch desorption experiments to generate data that could be modeled to simulate U(VI) transport through the capillary fringe at the 300 Area.

Both sediments 11D and 39B $(<2 \mathrm{~mm})$ were previously washed for 48 hours with a synthetic groundwater (SGW-2) equilibrated with calcite (see Table 3.5 for chemical composition) using a 1:2 solid-tosolution ratio. Fresh SGW-2-calcite solution was introduced after removing the first wash supernatant using a pipette after centrifugation. Multiple washings with the SGW-2-calcite solution were required, up to 18 and 72 days for sediment 39B and 11D, respectively, before the effluent U(VI) concentrations dropped below or near the drinking water standard $(30 \mu \mathrm{g} / \mathrm{L})$. Because of the high U(VI) concentration in the effluent of sediment 11D, sediment 11D was completely dried after 21 days reaction and restarted repetitive washing. Final U(VI) concentrations measured in the effluents after repetitive washings with SGW-2-calcite solution for sediments 39B and 11D were $19 \mu \mathrm{g} / \mathrm{L}$ and $33 \mu \mathrm{g} / \mathrm{L}$, respectively. 
Table 3.4. Groundwater Samples Analyzed by WSCF

\begin{tabular}{cc}
\hline $\begin{array}{c}\text { Sample Name } \\
\text { (HEIS ID) }\end{array}$ & $\begin{array}{c}\text { Sample Mid Depth } \\
\text { (ft bgs) }\end{array}$ \\
\hline \multicolumn{3}{c}{$399-2-5$} \\
\hline B1PL94 & 36.3 \\
B1PL95 & 48.0 \\
B1PL96 & 67.5 \\
B1PL98 & 72.5 \\
B1PL99 & 85.5 \\
B1PLB0 & 107.5 \\
B1PLB1 & 125.0 \\
\hline \multicolumn{3}{c}{$399-3-22$} \\
\hline B1PLB2 & 49.0 \\
B1PLB3 & 54.3 \\
B1PLB4 & 63.3 \\
B1PLB5 & 81.8 \\
B1PLB6 & 94.5 \\
B1PLB7 & 108.5 \\
B1PLB8 & 121.5 \\
B1PLB9 & 131.5 \\
\hline \multicolumn{3}{c}{$399-4-14$} \\
\hline B1PLC0 & 49.8 \\
B1PLC1 & 59.0 \\
B1PLC2 & 68.5 \\
B1PLC3 & 78.0 \\
B1PLC4 & 83.0 \\
B1PLC5 & 92.8 \\
B1PLC6 & 109.8 \\
B1PLC7 & 125.8 \\
\hline
\end{tabular}

Isotherms for $\mathrm{U}(\mathrm{VI})$ adsorption onto the previously washed sediments (11D and 39B) were developed using a 1:2 treated solid (after air drying)-to-solution ratio and SGW-2-calcite solution spiked with U(VI) concentrations varying from $0.076 \mathrm{mg} / \mathrm{L}\left(3.2 \times 10^{-7} \mathrm{M}\right)$ to $2.19 \mathrm{mg} / \mathrm{L}\left(9.2 \times 10^{-6} \mathrm{M}\right)$ in duplicate. A commercial certified ICP-MS U(VI) standard $\left(1000 \mathrm{mg} / \mathrm{L}\right.$ in $\left.1.0 \mathrm{wt} \% \mathrm{HNO}_{3}\right)$ was used after dilution to spike the SGW. After seven days of contact without atmospheric $\mathrm{CO}_{2}(\mathrm{~g})$, supernatants were separated by centrifugation and filtration using a $0.0036 \mu \mathrm{m}$ millipore membrane. Concentration of U(VI) in the spiked SGW was analyzed using ICP-MS and used to determine U(VI) concentrations both in solution and on the solid for $\mathrm{U}(\mathrm{VI})$ adsorption isotherm development. The amount of $\mathrm{U}(\mathrm{VI})$ adsorbed to the sediments was determined by difference between the initial U(VI) concentrations in the spiked synthetic groundwater and the final effluent concentrations after seven days of contact. Blank tubes were run previously to ensure that no $\mathrm{U}(\mathrm{VI})$ adsorbed to the containers and that $\mathrm{U}(\mathrm{VI})$ was stable in the SGW at the concentrations used. 
Table 3.5. Chemical Composition of Synthetic Groundwater (SGW-2-calcite)

\begin{tabular}{|c|c|}
\hline Constituents & Concentrations (M \\
\hline $\mathrm{Na}^{+}$ & $1.53 \times 10^{-3}$ \\
\hline $\mathrm{Ca}^{2+}$ & $6.21 \times 10^{-4}$ \\
\hline $\mathrm{K}^{+}$ & $4.30 \times 10^{-4}$ \\
\hline $\mathrm{Mg}^{2+}$ & $5.29 \times 10^{-4}$ \\
\hline $\mathrm{NO}_{3}^{-}$ & $5.71 \times 10^{-4}$ \\
\hline $\mathrm{SO}_{4}^{2-}$ & $9.81 \times 10^{-4}$ \\
\hline $\mathrm{TDIC}^{(\mathrm{a})}$ & $1.07 \times 10^{-3}$ \\
\hline $\mathrm{Br}^{-}$ & $6.23 \times 10^{-4}$ \\
\hline I (calculated) $)^{(b)}$ & $\mathrm{I}=0.0064 \mathrm{M}$ \\
\hline pH (measured) & $\mathrm{pH}=8.01$ \\
\hline
\end{tabular}

\subsubsection{Modeling of U(VI) Adsorption and Desorption}

A surface complexation reaction was used to describe $\mathrm{U}(\mathrm{VI})$ adsorption to and desorption from sediments 11D and 39B:

$$
\mathrm{SOH}+\mathrm{UO}_{2}^{2+}+\mathrm{CO}_{3}^{2-}=\mathrm{SOUO}_{2} \mathrm{HCO}_{3}
$$

where $\mathrm{SOH}$ represents the surface site, $\mathrm{SOUO}_{2} \mathrm{HCO}_{3}$ is the adsorbed $\mathrm{U}(\mathrm{VI})$ surface complex on the surface, and others are aqueous species. This surface complex reaction has previously been used to describe U(VI) desorption from the Hanford 300 Area sediments (Bond et al. 2008, Liu et al. 2008) and sediment beneath the TX tank farm (Zachara et al. 2007). Reaction (1) was coupled with aqueous U(VI) speciation reactions to formulate a surface complexation model based on a nonelectrostatic generalized composite approach (Davis et al. 2004). The equilibrium constant for U(VI) surface species, K (Equation 3.1), was determined by fitting the surface complexation model to the data from the U(VI) adsorption isotherms for the washed sediments 11D and 39B. The surface complexation model used a total surface adsorption site density of $7.56 \times 10^{-5}$ and $6.03 \times 10^{-5} \mathrm{~mol} / \mathrm{g}$ for sediments $11 \mathrm{D}$ and 39B, respectively, which were calculated from the measured surface areas $\left(19.7\right.$ and $15.7 \mathrm{~m}^{2} / \mathrm{g}$ for $11 \mathrm{D}$ and $39 \mathrm{~B}$, respectively) and a generic surface area based site density of $3.84 \times 10^{-6} \mathrm{~mol} / \mathrm{m}^{2}$ (Davis et al. 2004). Measured aqueous compositions at the adsorption equilibrium were used to compute major ion activities and $\mathrm{U}(\mathrm{VI})$ aqueous speciation. A total of eight chemical components $\left(\mathrm{UO}_{2}{ }^{2+}, \mathrm{H}^{+}, \mathrm{Ca}^{2+}, \mathrm{Mg}^{2+}, \mathrm{Na}^{+}\right.$, $\mathrm{H}_{4} \mathrm{SiO}_{4}{ }^{0}, \mathrm{CO}_{3}{ }^{2-}$, and $\mathrm{SOH}$ ) and 47 relevant $\mathrm{U}(\mathrm{VI})$ aqueous and surface complex species were used in the model simulation using a previously developed U(VI) thermodynamic database (Qafoku et al. 2005, Zachara et al. 2007) and the FITEQL 4.0 code (Herberlin and Westall 1999). The Davies equation was used in calculating activity coefficients of aqueous ions (Langmuir 1997). All the adsorbed U(VI) concentrations were normalized to local aqueous volume (pore volume in case of the column). In this case, only the aqueous U(VI) concentrations were calculated since all other chemical concentrations related to $\mathrm{U}(\mathrm{VI})$ adsorption had been determined previously. 



\subsection{Area Geology}

For each of the four new boreholes drilled as part of the VOC investigation, a composite borehole log has been prepared that summarizes the detailed information gathered during drilling and sampling. These logs are included in Appendix A so that they may be pulled out for reference while reading other portions of the report. Detailed information on drilling results is presented in a separate borehole summary report (Horner 2008). The composite borehole logs for the four earlier LFI boreholes are also included in Appendix A for completeness.

\subsection{Borehole Lithology}

The five most dominant lithofacies encountered during drilling, along with their associated hydrologic unit designations, are illustrated in Figure 4.1, and their depths and thicknesses are summarized in Table 4.1. Detailed descriptions for each of the five hydrogeologic units, from shallowest (i.e., youngest) to deepest (i.e., oldest), are provided in the following paragraphs. For additional background information on the stratigraphy beneath the 300 Area, refer to Gaylord and Poeter (1991), Swanson et al. (1992), and Lindsey (1995).

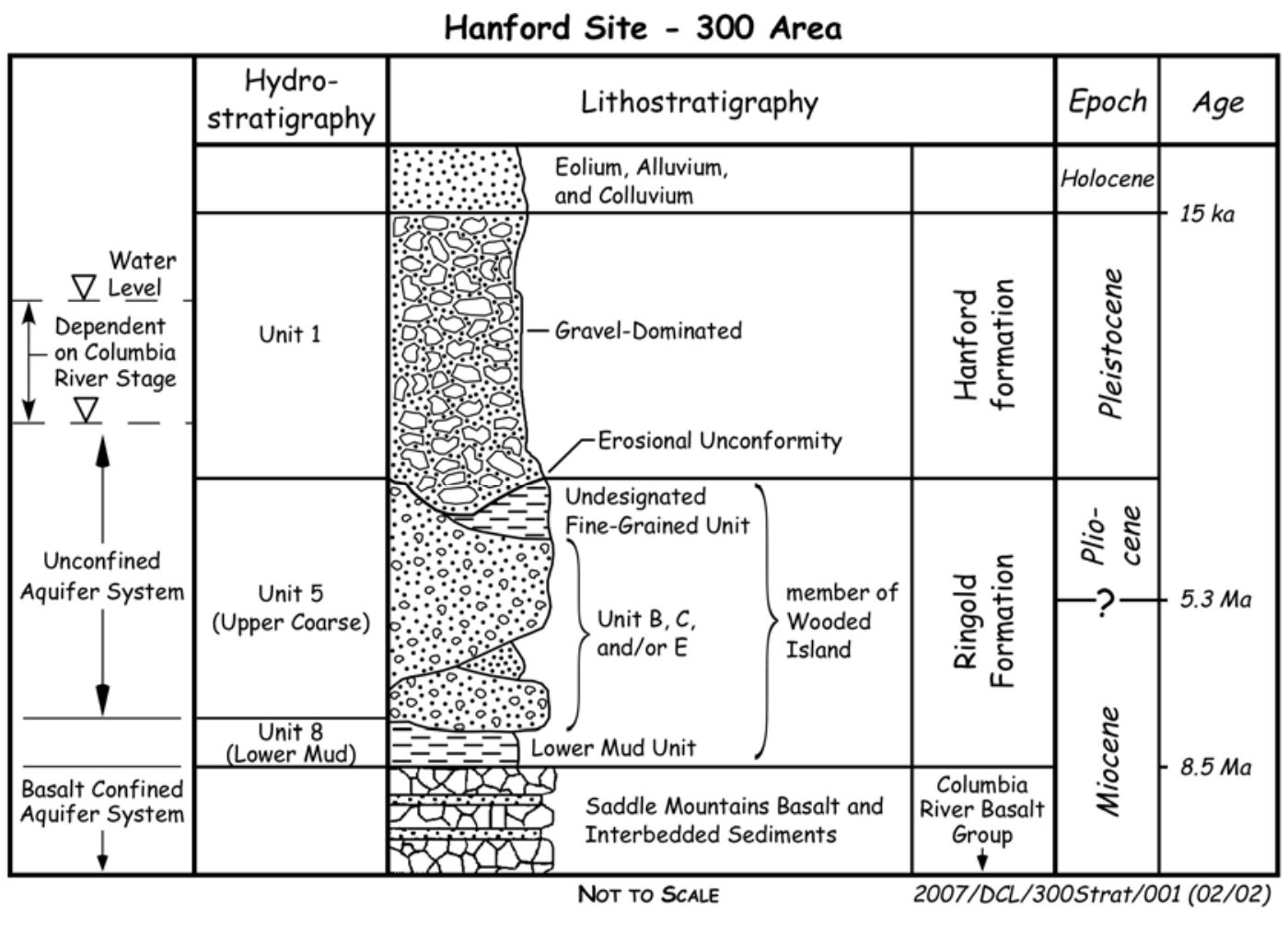

Modified for 300 Area after Reidel et. al. (1992), Thorne et al. (1993), Lindsey (1995), Williams et. al. (2000), DOE (2002)

Figure 4.1. Principal Hydrogeologic Units Beneath the 300 Area (Williams et al. 2007) 
Table 4.1. Summary Information on Major Stratigraphic Units (modified after Horner 2008)

\begin{tabular}{|c|c|c|c|c|c|c|}
\hline $\begin{array}{l}\text { Well Name } \\
\text { (Well ID) }\end{array}$ & $\begin{array}{l}399- \\
(\mathrm{C} 5\end{array}$ & & $\begin{array}{l}399- \\
(\mathrm{C} 57\end{array}$ & & & \\
\hline $\begin{array}{l}\text { Lithology and Hydrologic } \\
\text { Unit }^{(a)}\end{array}$ & $\begin{array}{c}\text { Depth } \\
\text { Interval } \\
\text { (ft bgs) } \\
\end{array}$ & $\begin{array}{c}\text { Unit } \\
\text { Thickness } \\
\text { (ft) }\end{array}$ & $\begin{array}{l}\text { Depth Interval } \\
\text { (ft bgs) }\end{array}$ & $\begin{array}{c}\text { Unit } \\
\text { Thickness } \\
(\mathrm{ft})\end{array}$ & $\begin{array}{c}\text { Depth } \\
\text { Interval } \\
\text { (ft bgs) }\end{array}$ & $\begin{array}{c}\text { Unit } \\
\text { Thickness } \\
\text { (ft) }\end{array}$ \\
\hline $\begin{array}{l}\text { Surficial Sediment } \\
\text { (Holocene) }\end{array}$ & $0-2$ & 2 & $0-7.5$ & 7.5 & $0-13$ & 13 \\
\hline $\begin{array}{l}\text { Hanford form. coarse } \\
\text { gravel (Unit 1) }\end{array}$ & $2-63.5$ & 61.5 & $7.5-67$ & 59.5 & $13-56$ & 43 \\
\hline $\begin{array}{l}\text { Ringold Form. } \\
\text { undesignated finer-grained } \\
\text { lithologies } \\
\text { (Unit 5) }\end{array}$ & $63.5-96$ & 32.5 & $67-94$ & 27 & $56-73$ & 17 \\
\hline $\begin{array}{l}\text { Ringold Form. coarse } \\
\text { gravel (Unit 5) }\end{array}$ & 96-135 & 39 & $94-130$ & 35.5 & $73-125$ & 52 \\
\hline $\begin{array}{l}\text { Ringold Form. mud/silt } \\
\text { (Unit 8) }\end{array}$ & $\begin{array}{c}135-141+ \\
(141=\mathrm{TD})^{(\mathrm{b})}\end{array}$ & Unknown & $\begin{array}{l}130-136+ \\
(136=\mathrm{TD})\end{array}$ & Unknown & $\begin{array}{l}125-131+ \\
(131=\mathrm{TD})\end{array}$ & Unknown \\
\hline
\end{tabular}

(a) Generalized stratigraphy representing the five most dominant lithofacies encountered during drilling of four boreholes in the 300 Area. Hydrologic units as currently adopted for use in groundwater flow models are also identified in parentheses.

(b) $\mathrm{TD}=$ total drilled depth.

\subsubsection{Surficial Sediment (Holocene)}

Recent surficial sediment (Holocene) is composed of reworked Hanford sandy gravel and Elian silt and sand deposits and/or backfill (anthropogenic) material and coal plant ash waste. These deposits

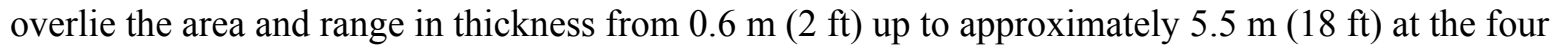
VOC investigation boreholes.

\subsubsection{Hanford Formation (Unit 1)}

Gravel-dominated sediment of the Hanford formation (Unit 1) makes up the remainder of the vadose zone and the upper, most permeable portion of the unconfined aquifer at all borehole locations. This unit is composed of unconsolidated and cast-supported sediment, with pebble- to boulder-sized gravel, and contains a poorly sorted matrix of fine- to coarse-grained sand. Silt content varies and locally fills most or all matrixes between gravel casts. Occasionally, the matrix is missing, which produces an openframework fabric. The Hanford formation ranges in thickness from $\sim 13.1 \mathrm{~m}(43 \mathrm{ft})$ to $\sim 18.7 \mathrm{~m}(62 \mathrm{ft})$ at the four borehole locations.

There are no easily distinguishable or readily mapped facies/hydrogeologic changes within the vadose zone in the area covered by these boreholes. There are isolated occurrences of older, reworked Ringold Formation sediment, which is distinguished by its more cohesive sediment structure, color, and/or degree of sorting. The reworked Ringold sediment may also contain zones with higher clay/silt content (Bjornstad 2004). Large Ringold rip-up clasts, up to several feet in diameter and composed of pure silt and clay, are occasionally present. One such clast, which was at least $0.5 \mathrm{ft}$ thick, was encountered during drilling at 399-2-5 from a depth of 47 feet bgs within the Hanford gravel formation. 


\subsubsection{Ringold Formation Undesignated Finer-Grained Interval (Unit 5)}

An erosional unconformity separates this interval of sand/silt lithofacies within the Ringold Formation from the overlying Hanford formation in some portions of the 300 Area. These lithofacies include predominantly silt or fine-, medium-, and coarse-grained sand (Figure 2.7). Within this interval, grain size appears to increase with depth. The presence of this relatively finer-grained interval within the generally coarse-grained sediment of the Ringold Formation was confirmed by grab and core samples collected from all four of the VOC investigation boreholes. The finer-grained interval was encountered at or near the Hanford/Ringold contact and ranges in thickness from $\sim 4 \mathrm{~m}(13 \mathrm{ft})$ at borehole 399-3-21 to $\sim 10 \mathrm{~m}(33 \mathrm{ft})$ at borehole 399-3-22.

\subsubsection{Ringold Formation Coarse Gravel (Unit 5)}

Underlying the relatively finer-grained interval is a coarse gravel lithofacies. It is composed of variably indurated, fluvial gravel to silty-sandy gravel and extends to the base of the unconfined aquifer. The range in thickness is $\sim 11 \mathrm{~m}(36 \mathrm{ft})$ to $\sim 16 \mathrm{~m}(52 \mathrm{ft})$. At some 300 Area locations, this gravel lithofacies may also be present above the relatively finer-grained interval.

Differences between the gravelly sediment in the much younger Hanford formation and the coarsegrained portions of the Ringold Formation include a distinct change in basalt content, color, consolidation, and better grain-sorting/grain-roundness in the older Ringold sediments. Other contrasts include significant differences in hydraulic properties as revealed by aquifer tests (e.g., much lower hydraulic conductivity in Ringold than in Hanford sediment), and differences in the total gamma activity of the sediment (e.g., variability in amount of natural potassium-40).

\subsubsection{Ringold Formation Lower Mud (Unit 8)}

The Ringold Formation lower mud unit, which underlies the Ringold Formation gravelly sediment, is an aquitard that forms the lower boundary of the unconfined aquifer system. This aquitard separates the confined aquifers in the underlying Columbia River basalt group from the overlying unconfined aquifer. The lower mud unit comprises silty clay to silty sand and forms a sharp, well-defined contact boundary with the overlying fluvial gravel sediment. The VOC investigation boreholes were drilled approximately

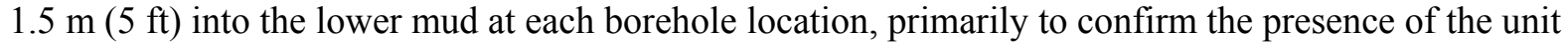
and to enable geophysical logging across the contact boundary. 



\subsection{Geochemical Results and Discussion}

This section presents the geochemical and physical characterization data collected on sediment from three of the VOC wells emplaced within the 300 Area of the Hanford Site. The activities employed emphasized tests that provided basic characterization data and were important in determining the distribution of uranium in the vadose zone and aquifer sediments. Such information on the sediments included moisture content, total and inorganic carbon content, $\mathrm{pH}, \mathrm{EC}$, and measurements of major cations, anions, and trace metals (including uranium-238) in 1:1 sediment:water and $8 \mathrm{M}$ nitric acid extracts, as well as microwave-assisted digests. Additional U(VI) adsorption and desorption experiments using sediment collected during the 300-FF-5 LFI (C4999-11D and C5000-39B) were included to understand U(VI) transport through the capillary fringe sediments at the 300 Area.

\subsection{Sediment from Well 399-2-5 (Borehole C5708)}

\subsubsection{Moisture Content}

The moisture content of the 36 core liners, six moisture tins, and two grab samples collected while drilling well 399-2-5 is listed as a function of depth in Table 5.1. The moisture content profile correlates with the lithology described in Section 4 and presented in Table 4.1. In general, the gravel-dominated sediment of the Hanford formation had low moisture content, an average vadose zone moisture content of $8.13 \mathrm{wt} \%$. Several samples collected within the Hanford formation vadose zone exhibited much higher moisture content, $12-17 \mathrm{wt} \%$, indicating that certain depths contained more fine-grained sediment. In comparison, the surficial sediment composed of reworked Hanford sandy gravel and eolian silt and sand deposits and/or backfill (anthropogenic) material and coal plant ash waste had average moisture content of $6.65 \mathrm{wt} \%$, with a narrow range in measured moisture contents of 5.15 to $8.55 \mathrm{wt} \%$. The narrower range in measured moisture content is not surprising given that the material has been reworked and reconstituted as backfill. The remaining Hanford and Ringold Formation sediments were collected below the water table (approximately $33 \mathrm{ft} \mathrm{bgs}$ ); thus their measured moisture content reflects the ability of the sediments to retain pore water as they were brought to the surface in the core barrel. The measured moisture content of the samples can be used to qualitatively identify the location (depth) of finer-grained material in this borehole. This qualitative assessment confirms the lithology described in Table 4.1 that indicates the Ringold Formation undesignated finer-grained interval begins at approximately $56 \mathrm{ft}$ bgs at this location and extends to $73 \mathrm{ft}$ bgs. Although once saturated, the two sediments collected within this depth range during the drilling of well 399-2-5 contained 26.7 and $31.1 \mathrm{wt} \%$ moisture, respectively.

\subsubsection{1:1 Sediment:Water Extracts of Sediments from Well 399-2-5}

A subset of sediments from well 399-2-5 was characterized by performing 1:1 sediment:water extracts. The tables in this section present the mass of a given constituent leached per gram of sediment as measured in the water extracts; the figures show dilution-corrected values that represent concentrations in vadose zone pore water (this was calculated using the moisture content data obtained on opening the samples in the laboratory). The assumption that none of the solid is dissolved during the water extraction process is simplistic. In comparisons of actual vadose zone sediment pore water, which was obtained via ultracentrifugation of sediments, to the dilution-corrected calculated pore waters from both contaminated and uncontaminated sediments from the SX and B-BX Tank Farms (see Serne et al. 2002b, 2002c, 2002d, 
2002e, 2002f), it was found that for highly contaminated sediments the comparison is quite good. For slightly contaminated or uncontaminated sediments, the dilution-corrected water extract data are biased high by a factor of 2 to 7 for many constituents such that the true pore water is less saline. Further comparisons are made in later sections between calculated pore water concentrations and those directly extracted from the sediments using UFA.

Table 5.1. Gravimetric Moisture Content of Samples Retrieved from Well 399-2-5

\begin{tabular}{|c|c|c|}
\hline $\begin{array}{l}\text { Sample Name } \\
\text { (HEIS ID) }\end{array}$ & $\begin{array}{l}\text { Sample Mid Depth } \\
\text { (ft bgs) }\end{array}$ & $\begin{array}{c}\text { Moisture Content } \\
(\mathrm{wt} \%)\end{array}$ \\
\hline B1PL45-4 & 4.8 & 5.15 \\
\hline B1PL45-3 & 5.4 & 8.55 \\
\hline B1PL45-2 & 6.1 & 8.05 \\
\hline B1PL45-1 & 6.7 & 6.23 \\
\hline B1PL27 & 10.0 & 5.29 \\
\hline B1PL46-4 & 15.3 & 3.65 \\
\hline B1PL46-3 & 15.8 & 5.40 \\
\hline B1PL46-2 & 16.3 & 5.46 \\
\hline B1PL46-1 & 16.8 & 4.50 \\
\hline B1PL28 & 16.8 & 5.82 \\
\hline B1PL47-3 & 20.4 & 8.30 \\
\hline B1PL47-2 & 21.3 & 7.97 \\
\hline B1PL47-1 & 22.1 & 8.00 \\
\hline B1PL29 & 22.1 & 9.80 \\
\hline B1PL48-4 & 23.9 & 3.21 \\
\hline B1PL48-3 & 24.8 & 11.9 \\
\hline B1PL48-2 & 25.7 & 11.6 \\
\hline B1PL48-1 & 26.6 & 16.6 \\
\hline B1PL30 & 26.8 & 13.3 \\
\hline B1PL49-4 & 28.3 & 2.58 \\
\hline B1PL49-3 & 28.9 & 16.9 \\
\hline B1PL49-2 & 29.6 & 12.8 \\
\hline B1PL49-1 & 30.2 & 0.86 \\
\hline B1PL31 & 30.0 & 8.71 \\
\hline B1PL50-3 & 34.3 & 1.09 \\
\hline B1PL50-2 & 35.3 & 8.73 \\
\hline B1PL50-1 & 36.3 & 8.29 \\
\hline B1PL32 & 36.3 & 2.60 \\
\hline B1PL51-3 & 41.3 & 11.3 \\
\hline B1PL51-2 & 42.3 & 6.44 \\
\hline B1PL51-1 & 43.3 & 7.36 \\
\hline B1PL52-4 & 44.8 & 19.4 \\
\hline B1PL52-3 & 45.5 & 6.61 \\
\hline B1PL52-2 & 46.3 & 7.86 \\
\hline B1PL52-1 & 47.0 & 31.9 \\
\hline B1PL53-3 & 50.0 & 6.93 \\
\hline B1PL53-2 & 51.0 & 7.31 \\
\hline B1PL53-1 & 52.0 & 9.02 \\
\hline C5707-56.5 & 56.5 & 26.7 \\
\hline C5708-67 & 67.0 & 31.1 \\
\hline B1PL54-4 & 73.3 & 24.1 \\
\hline B1PL54-3 & 73.8 & 22.5 \\
\hline B1PL54-2 & 74.3 & 12.1 \\
\hline B1PL54-1 & 74.8 & 11.1 \\
\hline
\end{tabular}




\subsubsection{1 pH and Electrical Conductivity}

The $\mathrm{pH}$ and EC of the water extracts from select samples from well 399-2-5 are shown in Table 5.2. The values of both parameters are tabulated as measured in the 1:1 sediment:water extracts. Further, the measured values of EC were also corrected back to a pore water concentration based on field moisture contents and is reported as pore water-corrected in the table. The $\mathrm{pH}$ profile is constant, with all values between 7.2 and 8.0 (the typical range for Hanford sediments is 7 to 8.5 ). The pore water-corrected EC data are considerably more variable, with a range of 0.437 to $25.2 \mathrm{mS} / \mathrm{cm}$ in the Hanford formation and 0.437 to $5.66 \mathrm{mS} / \mathrm{cm}$ in the Ringold Formation. The peak pore water corrected EC value of $25.2 \mathrm{mS} / \mathrm{cm}$ measured in the sample collected from approximately $30 \mathrm{ft} \mathrm{bgs}$ is primarily a result of the sample's very low moisture content $(0.86 \mathrm{wt} \%)$. Correcting the relatively low EC measured in the 1:1 sediment:water extract $(0.218 \mathrm{mS} / \mathrm{cm})$ by a very large dilution factor resulted in what is likely an erroneously high pore water corrected EC value. Overall, the calculated pore water conductivities were dilute and compared well with pore water conductivity data measured in other 300 Area boreholes (Williams et al. 2007). Specifically, pore water conductivities ranged from 0.318 to $12.7 \mathrm{mS} / \mathrm{cm}$ in borehole C4999 and from 0.59 to 6.38 in borehole C5000.

Table 5.2. $\mathrm{pH}$ for 1:1 Sediment:Water Extracts and Dilution-Corrected EC Values from Well 399-2-5

\begin{tabular}{lcccc}
\hline $\begin{array}{c}\text { Sample Name } \\
\text { (HEIS ID) }\end{array}$ & $\begin{array}{c}\text { Sample Mid Depth } \\
\text { (ft bgs) }\end{array}$ & $\mathrm{pH}$ & $\begin{array}{c}\mathrm{EC} \\
(\mathrm{mS} / \mathrm{cm})\end{array}$ & $\begin{array}{c}\text { Pore Water-Corrected } \\
\text { Conductivity } \\
\text { (mS/cm) }\end{array}$ \\
\hline B1PL46-1 DUP & 16.8 & 7.56 & $1.80 \mathrm{E}-01$ & $4.00 \mathrm{E}+00$ \\
B1PL46-1 & 16.8 & 7.50 & $1.76 \mathrm{E}-01$ & $3.91 \mathrm{E}+00$ \\
B1PL47-1 & 22.1 & 7.54 & $3.16 \mathrm{E}-01$ & $3.95 \mathrm{E}+00$ \\
B1PL48-1 & 26.6 & 7.26 & $2.64 \mathrm{E}-01$ & $1.58 \mathrm{E}+00$ \\
B1PL49-3 & 28.9 & 7.87 & $2.56 \mathrm{E}-01$ & $1.51 \mathrm{E}+00$ \\
B1PL49-1 & 30.2 & 7.67 & $2.18 \mathrm{E}-01$ & $2.52 \mathrm{E}+01$ \\
B1PL50-2 & 35.3 & 7.52 & $1.20 \mathrm{E}-01$ & $1.38 \mathrm{E}+00$ \\
B1PL50-2 DUP & 35.3 & 7.76 & $1.62 \mathrm{E}-01$ & $1.86 \mathrm{E}+00$ \\
B1PL50-1 & 36.3 & 7.65 & $1.73 \mathrm{E}-01$ & $2.09 \mathrm{E}+00$ \\
B1PL51-1 & 43.3 & 7.27 & $8.00 \mathrm{E}-02$ & $1.09 \mathrm{E}+00$ \\
B1PL52-1 & 47.0 & 7.47 & $2.29 \mathrm{E}-01$ & $7.10 \mathrm{E}-01$ \\
B1PL53-3 & 50.0 & 7.36 & $7.04 \mathrm{E}-01$ & $1.01 \mathrm{E}+01$ \\
C5708-56.5 & 56.5 & 7.48 & $1.18 \mathrm{E}-01$ & $4.37 \mathrm{E}-01$ \\
C5708-67 & 67.0 & 7.45 & $3.41 \mathrm{E}-01$ & $1.09 \mathrm{E}+00$ \\
B1PL54-2 & 74.3 & 7.66 & $6.82 \mathrm{E}-01$ & $5.66 \mathrm{E}+00$ \\
B1PL54-1 & 74.8 & 7.85 & $2.23 \mathrm{E}-01$ & $2.01 \mathrm{E}+00$ \\
\hline
\end{tabular}

\subsubsection{Composition of the 1:1 Sediment:Water Extracts from Well 399-2-5}

The concentrations of major anions, cations, and several trace constituents are discussed in this subsection. The anion data are tabulated in Table 5.3 in units of mass per gram of dry sediment. A comparison of the masses of water-extractable anions per gram of sediment from the Hanford and Ringold Formation Units in well 399-2-5 showed that overall there is little difference in the anion composition between the two formations. The primary water-extractable anions in both units were bicarbonate and sulfate. Additionally, samples retrieved from between 16 and $27 \mathrm{ft}$ bgs clearly contain nitrate contamination. The average water-extractable nitrate concentration in these four samples is $28.4 \mu \mathrm{g} / \mathrm{g}$ versus just $4.81 \mu \mathrm{g} / \mathrm{g}$ in the background 300 Area sediment (B11493) reported by Serne et al. 
(2002a). The peak water-extractable nitrate measured by Serne et al. (2002a) was in sample B11494, which was collected within the NPP, with a concentration of $106 \mu \mathrm{g} / \mathrm{g}$. In comparison, the peak waterextractable nitrate measured by Williams et al. (2007) was in borehole C4999 at a depth of approximately $9 \mathrm{ft}$ bgs with a concentration of $580 \mu \mathrm{g} / \mathrm{g}$. However, samples retrieved within $13 \mathrm{ft}$ of ground surface at borehole C4999 contained significant quantities of fly ash, which has likely affected the amount of contaminant nitrate in the shallow vadose zone at that location. Conversely, the source of nitrate in samples from well 399-2-5 is likely from the large quantity of nitrate disposed to the pond (Zachara et al. [2005] indicate that in excess of two million $\mathrm{kg}$ of nitrate was discharged to the NPP and SPP) as sodium nitrate that was formed when nitric acid waste was neutralized with sodium hydroxide before being discharged to the ponds.

Table 5.3. Water-Extractable Anions in Sediments from Well 399-2-5 ( $\mu \mathrm{g} / \mathrm{g}$ dry sediment $)^{(\mathrm{a})}$

\begin{tabular}{lccccccc}
\hline $\begin{array}{c}\text { Sample Name } \\
(\text { HEIS ID) }\end{array}$ & $\begin{array}{c}\text { Sample } \\
\text { Mid Depth } \\
(\mathrm{ft} \text { bgs })\end{array}$ & $\begin{array}{c}\text { Fluoride } \\
(\mu \mathrm{g} / \mathrm{g})\end{array}$ & $\begin{array}{c}\text { Chloride } \\
(\mu \mathrm{g} / \mathrm{g})\end{array}$ & $\begin{array}{c}\text { Nitrate } \\
(\mu \mathrm{g} / \mathrm{g})\end{array}$ & $\begin{array}{c}\text { Sulfate } \\
(\mu \mathrm{g} / \mathrm{g})\end{array}$ & $\begin{array}{c}\text { Phosphate } \\
(\mu \mathrm{g} / \mathrm{g})\end{array}$ & $\begin{array}{c}\text { Alkalinity } \\
\text { as CaCO } \\
(\mu \mathrm{g} / \mathrm{g})\end{array}$ \\
\hline B1PL46-1 DUP & 16.8 & $6.25 \mathrm{E}-01$ & $2.14 \mathrm{E}+00$ & $1.99 \mathrm{E}+01$ & $2.75 \mathrm{E}+01$ & $<1.50 \mathrm{E}+00$ & $3.50 \mathrm{E}+01$ \\
B1PL46-1 & 16.8 & $6.19 \mathrm{E}-01$ & $2.13 \mathrm{E}+00$ & $1.98 \mathrm{E}+01$ & $2.48 \mathrm{E}+01$ & $<1.50 \mathrm{E}+00$ & $3.96 \mathrm{E}+01$ \\
B1PL47-1 & 22.1 & $6.61 \mathrm{E}-01$ & $6.70 \mathrm{E}+00$ & $3.74 \mathrm{E}+01$ & $7.12 \mathrm{E}+01$ & $<1.50 \mathrm{E}+00$ & $3.88 \mathrm{E}+01$ \\
B1PL48-1 & 26.6 & $7.05 \mathrm{E}-01$ & $1.51 \mathrm{E}+01$ & $3.63 \mathrm{E}+01$ & $4.57 \mathrm{E}+01$ & $<1.50 \mathrm{E}+00$ & $2.43 \mathrm{E}+01$ \\
B1PL49-1 & 30.2 & $1.04 \mathrm{E}+00$ & $9.14 \mathrm{E}+00$ & $<1.00 \mathrm{E}+00$ & $4.01 \mathrm{E}+01$ & $<1.50 \mathrm{E}+00$ & $5.03 \mathrm{E}+01$ \\
B1PL50-2 & 35.3 & $6.07 \mathrm{E}-01$ & $2.80 \mathrm{E}+00$ & $<1.00 \mathrm{E}+00$ & $2.05 \mathrm{E}+01$ & $<1.50 \mathrm{E}+00$ & $3.34 \mathrm{E}+01$ \\
B1PL51-1 & 43.3 & $6.71 \mathrm{E}-01$ & $2.81 \mathrm{E}+00$ & $1.19 \mathrm{E}+00$ & $1.24 \mathrm{E}+01$ & $<1.50 \mathrm{E}+00$ & $1.98 \mathrm{E}+01$ \\
C5708-56.5 & 56.5 & $4.44 \mathrm{E}-01$ & $4.43 \mathrm{E}+00$ & $4.93 \mathrm{E}+00$ & $1.29 \mathrm{E}+01$ & $<1.50 \mathrm{E}+00$ & $3.50 \mathrm{E}+01$ \\
C5708-67 & 67.0 & $2.46 \mathrm{E}-01$ & $1.95 \mathrm{E}+00$ & $3.37 \mathrm{E}+00$ & $1.24 \mathrm{E}+02$ & $<1.50 \mathrm{E}+00$ & $3.05 \mathrm{E}+01$ \\
B1PL54-1 & 74.8 & $3.60 \mathrm{E}-01$ & $1.24 \mathrm{E}+00$ & $<9.94 \mathrm{E}-01$ & $5.57 \mathrm{E}+01$ & $<1.49 \mathrm{E}+00$ & $4.53 \mathrm{E}+01$ \\
\hline (a) < symbol indicates the analyte was below the detection limit. The minimum detection limit has been reported.
\end{tabular}

The water-extractable major cations in sediments from well 399-2-5 are tabulated in Table 5.4 in units of mass per gram of sediment on a dry weight basis. The dominant water-extractable cations in the sediments from well 399-2-5 were calcium and sodium. Typically, calcium and magnesium are the dominant water-extractable cations for Hanford sediments that have not been affected by waste streams. Again, the slightly excess sodium found in samples from well 399-2-5 was likely a result of the addition of sodium hydroxide to the pond in an effort to neutralize the acidic waste. Like the anions, the concentrations of water-extractable cations were fairly consistent between the Hanford and Ringold Formation sediments.

The water-extractable aluminum, iron, sulfur, and phosphorus in sediments collected from well 399-2-5 are shown in Table 5.5. The sulfur and phosphorus data were converted to water-extractable sulfur as sulfate and phosphorus as phosphate so the results could be compared to the IC data in Table 5.3. The agreement between directly measured sulfate in the water extracts using IC and indirectly by converting the ICP measurements for sulfur to sulfate was very good. Relative percent differences between the two data sets ranged from 0.5 to $4.7 \%$. Neither analytical technique was capable of detecting water-extractable phosphates in any of the samples analyzed. Trace amounts of water-soluble iron and aluminum were detected in $40 \%$ of the samples analyzed from well 399-2-5. Typically, iron and aluminum are present in natural mineral phases that are recalcitrant to water leaching. The presence of small quantities of both elements in the same 1:1 sediment:water extract samples likely indicates that the mineralogical properties of the sediments have been altered through contact with the caustic waste streams disposed to the SPP. 
Table 5.4. Water-Extractable Major Cations in Sediments from Well 399-2-5 ( $\mu \mathrm{g} / \mathrm{g}$ dry sediment)

\begin{tabular}{|c|c|c|c|c|c|c|}
\hline $\begin{array}{c}\text { Sample Name } \\
\text { (HEIS ID) }\end{array}$ & $\begin{array}{c}\text { Sample } \\
\text { Mid Depth } \\
(\mathrm{ft} \text { bgs })\end{array}$ & $\begin{array}{l}\text { Calcium } \\
(\mu \mathrm{g} / \mathrm{g})\end{array}$ & $\begin{array}{c}\text { Potassium } \\
(\mu \mathrm{g} / \mathrm{g})\end{array}$ & $\begin{array}{c}\text { Magnesium } \\
(\mu \mathrm{g} / \mathrm{g})\end{array}$ & Strontium $(\mu \mathrm{g} / \mathrm{g})$ & $\begin{array}{c}\text { Sodium } \\
(\mu \mathrm{g} / \mathrm{g})\end{array}$ \\
\hline B1PL46-1 DUP & 16.8 & $1.56 \mathrm{E}+01$ & $3.02 \mathrm{E}+00$ & $2.46 \mathrm{E}+00$ & $7.00 \mathrm{E}-02$ & $1.06 \mathrm{E}+01$ \\
\hline B1PL46-1 & 16.8 & $1.50 \mathrm{E}+01$ & $2.85 \mathrm{E}+00$ & $2.40 \mathrm{E}+00$ & $6.63 \mathrm{E}-02$ & $1.01 \mathrm{E}+01$ \\
\hline B1PL47-1 & 22.1 & $3.13 \mathrm{E}+01$ & $4.13 \mathrm{E}+00$ & $5.10 \mathrm{E}+00$ & $1.44 \mathrm{E}-01$ & $1.50 \mathrm{E}+01$ \\
\hline B1PL48-1 & 26.6 & $2.18 \mathrm{E}+01$ & $4.06 \mathrm{E}+00$ & $4.10 \mathrm{E}+00$ & $1.08 \mathrm{E}-01$ & $1.59 \mathrm{E}+01$ \\
\hline B1PL49-1 & 30.2 & $1.74 \mathrm{E}+01$ & $3.84 \mathrm{E}+00$ & $3.30 \mathrm{E}+00$ & 7.97E-02 & $1.51 \mathrm{E}+01$ \\
\hline B1PL50-2 & 35.3 & $8.14 \mathrm{E}+00$ & $2.80 \mathrm{E}+00$ & $1.77 \mathrm{E}+00$ & $3.88 \mathrm{E}-02$ & $8.37 \mathrm{E}+00$ \\
\hline B1PL51-1 & 43.3 & $3.58 \mathrm{E}+00$ & $2.09 \mathrm{E}+00$ & $8.18 \mathrm{E}-01$ & $1.87 \mathrm{E}-02$ & $7.29 \mathrm{E}+00$ \\
\hline C5708-56.5 & 56.5 & $7.44 \mathrm{E}+00$ & $4.03 \mathrm{E}+00$ & $1.58 \mathrm{E}+00$ & $3.52 \mathrm{E}-02$ & $8.36 \mathrm{E}+00$ \\
\hline C5708-67 & 67.0 & $3.36 \mathrm{E}+01$ & $9.52 \mathrm{E}+00$ & $8.47 \mathrm{E}+00$ & $1.74 \mathrm{E}-01$ & $1.00 \mathrm{E}+01$ \\
\hline B1PL54-1 & 74.8 & $1.66 \mathrm{E}+01$ & $8.01 \mathrm{E}+00$ & $4.34 \mathrm{E}+00$ & $8.62 \mathrm{E}-02$ & $1.12 \mathrm{E}+01$ \\
\hline
\end{tabular}

Table 5.5. Water-Extractable Cations in Sediments from Well 399-2-5 ( $\mu \mathrm{g} / \mathrm{g}$ dry sediment $)^{(\mathrm{a})}$

\begin{tabular}{lccccc}
\hline $\begin{array}{c}\text { Sample Name } \\
\text { (HEIS ID) }\end{array}$ & $\begin{array}{c}\text { Sample Mid } \\
\text { Depth } \\
(\mathrm{ft} \mathrm{bgs})\end{array}$ & $\begin{array}{c}\text { Aluminum } \\
(\mu \mathrm{g} / \mathrm{g})\end{array}$ & $\begin{array}{c}\text { Iron }(\mu \mathrm{g} / \mathrm{g}) \\
\text { Sulfur as } \\
\mathrm{SO}_{4}{ }^{2-}(\mu \mathrm{g} / \mathrm{g})\end{array}$ & $\begin{array}{c}\text { Phosphorus as } \\
\mathrm{PO}_{4}{ }^{3-}(\mu \mathrm{g} / \mathrm{g})\end{array}$ \\
\hline B1PL46-1 DUP & 16.8 & $5.02 \mathrm{E}-02$ & $5.05 \mathrm{E}-02$ & $2.65 \mathrm{E}+01$ & $<1.15 \mathrm{E}+00$ \\
B1PL46-1 & 16.8 & $5.47 \mathrm{E}-02$ & $5.73 \mathrm{E}-02$ & $2.37 \mathrm{E}+01$ & $<1.15 \mathrm{E}+00$ \\
B1PL47-1 & 22.1 & $<3.00 \mathrm{E}-02$ & $<3.00 \mathrm{E}-02$ & $7.01 \mathrm{E}+01$ & $<1.15 \mathrm{E}+00$ \\
B1PL48-1 & 26.6 & $<3.00 \mathrm{E}-02$ & $<3.00 \mathrm{E}-02$ & $4.53 \mathrm{E}+01$ & $<1.15 \mathrm{E}+00$ \\
B1PL49-1 & 30.2 & $<3.01 \mathrm{E}-02$ & $<3.01 \mathrm{E}-02$ & $3.99 \mathrm{E}+01$ & $<1.15 \mathrm{E}+00$ \\
B1PL50-2 & 35.3 & $5.57 \mathrm{E}-02$ & $5.24 \mathrm{E}-02$ & $2.03 \mathrm{E}+01$ & $<1.15 \mathrm{E}+00$ \\
B1PL51-1 & 43.3 & $5.99 \mathrm{E}-02$ & $6.09 \mathrm{E}-02$ & $1.23 \mathrm{E}+01$ & $<1.15 \mathrm{E}+00$ \\
C5708-56.5 & 56.5 & $<3.00 \mathrm{E}-02$ & $<3.00 \mathrm{E}-02$ & $1.25 \mathrm{E}+01$ & $<1.15 \mathrm{E}+00$ \\
C5708-67 & 67.0 & $<3.01 \mathrm{E}-02$ & $<3.01 \mathrm{E}-02$ & $1.22 \mathrm{E}+02$ & $<1.15 \mathrm{E}+00$ \\
B1PL54-1 & 74.8 & $<2.98 \mathrm{E}-02$ & $<2.98 \mathrm{E}-02$ & $5.84 \mathrm{E}+01$ & $<1.14 \mathrm{E}+00$ \\
\hline (a) $<$ symbol indicates the analyte was below the detection limit. The minimum detection limit has been reported. \\
\hline
\end{tabular}

The water extract data for uranium-238 are shown in Table 5.6; the results are tabulated as a function of dry sediment weight in units of mass $(\mu \mathrm{g} / \mathrm{g})$. The total number of samples analyzed for uranium-238 content is greater than those measured for anions and cations due to a second round of analyses being performed to better constrain the profile of contaminant uranium in this borehole. All of the samples analyzed contained quantifiable concentrations of water-extractable uranium-238. Uranium is a naturally occurring element and, as such, is generally quantifiable in water extracts of any sediment analyzed (see dashed vertical line in Figure 5.1). In addition to natural uranium, several of the samples contained quantifiable concentrations of contaminant uranium. These sediments were retrieved within the vadose zone, between 16 and $31 \mathrm{ft} \mathrm{bgs,} \mathrm{and} \mathrm{deeper} \mathrm{into} \mathrm{the} \mathrm{aquifer} \mathrm{at} \mathrm{approximately} 75 \mathrm{ft} \mathrm{bgs}$. While contaminant uranium is clearly present in sediments form this borehole, the peak concentration of $2.06 \mathrm{E}-02 \mu \mathrm{g} / \mathrm{g}$ is still fairly dilute. A noteworthy occurrence based on the water extract data is that the peak uranium concentration found at this location resides just above the water table in the region known as the capillary fringe. This is particularly important because the depth of the water table (and subsequently capillary fringe) fluctuates as a function of river stage in the 300 Area. As the Columbia River rises, river water infiltrates the 300 Area aquifer, resulting in an overall elevation of the water table. As the water table rises, 300 Area groundwater comes into contact with this source of contaminant uranium in the vadose zone. Some of the contaminant uranium is presumably leached from the sediment during this elevated river stage and acts as a source term to the groundwater plume underlying the 300 Area. 
Table 5.6. Water-Extractable Uranium in Sediments from Well 399-2-5

\begin{tabular}{lcc}
\hline $\begin{array}{c}\text { Sample Name } \\
\text { (HEIS ID) }\end{array}$ & $\begin{array}{c}\text { Sample Mid Depth } \\
(\mathrm{ft} \text { bgs })\end{array}$ & $\begin{array}{c}\text { Uranium-238 } \\
(\mu \mathrm{g} / \mathrm{g})\end{array}$ \\
\hline B1PL46-1 DUP & 16.8 & $1.06 \mathrm{E}-02$ \\
B1PL46-1 & 16.8 & $1.19 \mathrm{E}-02$ \\
B1PL47-1 & 22.1 & $1.44 \mathrm{E}-02$ \\
B1PL48-1 & 26.6 & $2.00 \mathrm{E}-03$ \\
B1PL49-3 & 28.9 & $1.42 \mathrm{E}-02$ \\
B1PL49-1 & 30.2 & $2.06 \mathrm{E}-02$ \\
B1PL50-2 & 35.3 & $2.63 \mathrm{E}-03$ \\
B1PL50-2 DUP & 35.3 & $1.81 \mathrm{E}-03$ \\
B1PL50-1 & 36.3 & $2.82 \mathrm{E}-03$ \\
B1PL51-1 & 43.3 & $2.39 \mathrm{E}-04$ \\
B1PL52-1 & 47.0 & $4.90 \mathrm{E}-04$ \\
B1PL53-3 & 50.0 & $1.65 \mathrm{E}-04$ \\
C5708-56.5 & 56.5 & $1.59 \mathrm{E}-04$ \\
C5708-67 & 67.0 & $2.63 \mathrm{E}-03$ \\
B1PL54-2 & 74.3 & $8.92 \mathrm{E}-03$ \\
B1PL54-1 & 74.8 & $8.30 \mathrm{E}-03$ \\
\hline
\end{tabular}

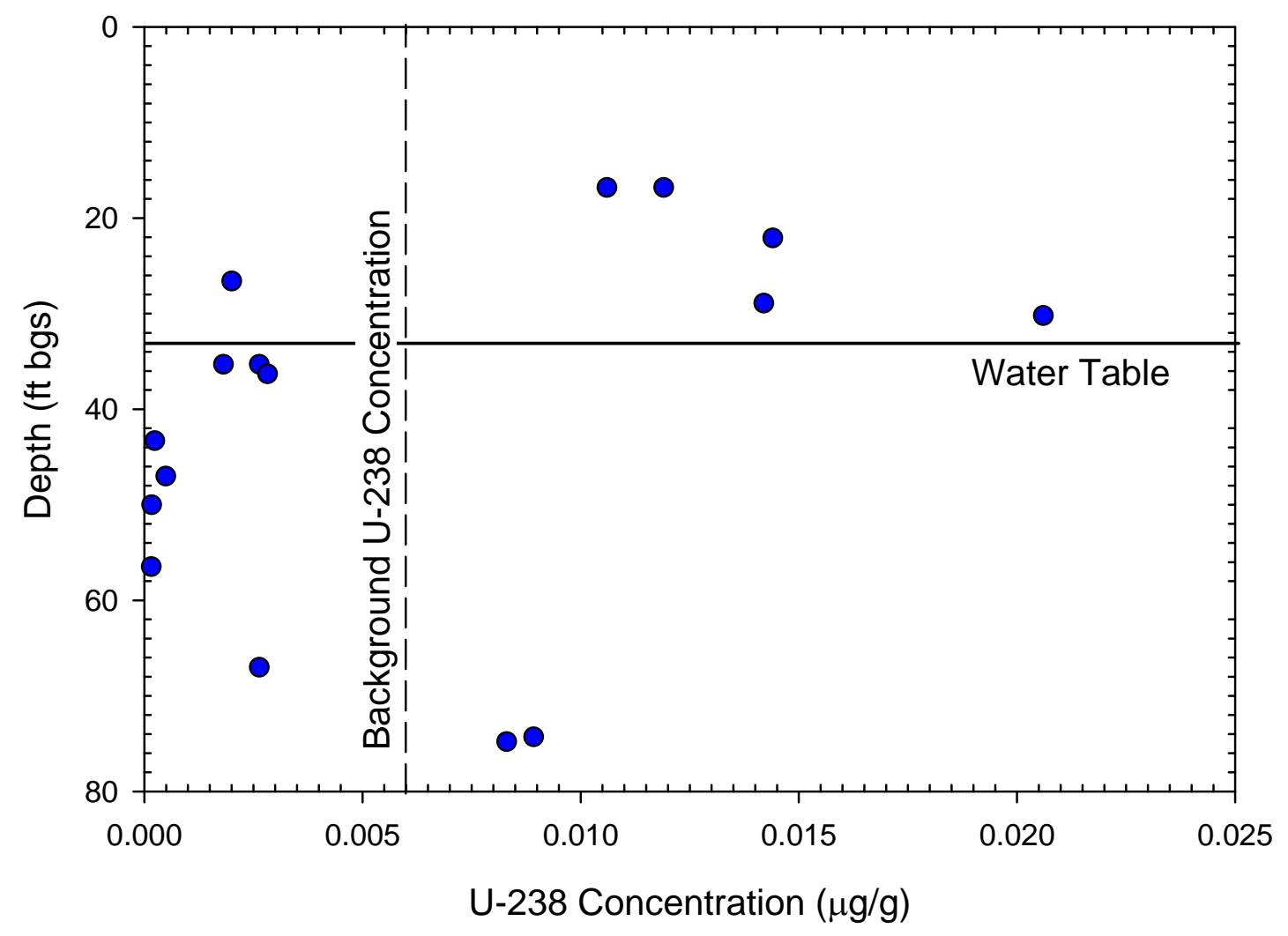

Figure 5.1. Concentration of Water-Extractable Uranium-238 in Sediments from Well 399-2-5 


\subsubsection{Pore Water Chemical Composition}

The chemical composition of the residual pore water in sediments from well 399-2-5 can be ascertained in two ways. The first method uses the 1:1 sediment:water extract results presented in Section 5.1.2 and the measured moisture content of the field-moist sediments (Section 5.1.1). Using this approach, the concentrations of the respective analytes measured in the 1:1 sediment:water extracts are assumed to be wholly present in the residual pore water. Although these samples were air-dried before extraction, it is reasonable to assume that the 1:1 sediment:water extract would have efficiently dissolved the constituents that precipitated on drying of the samples. Thus, by attributing the concentrations of dissolved species in the extracts to the field moist residual pore water, an estimate of the actual chemical composition of the native pore water in the vadose zone sediments can be derived. The second method is more direct: simply extracting the residual pore water using ultracentrifugation with an unsaturated flow apparatus (UFA). The extracted pore water can then be analyzed with no further dilution.

\subsubsection{Pore Water $\mathrm{pH}$ and EC}

Table 5.7 contains the $\mathrm{pH}$ and EC data for UFA extracts of sediments from well 399-2-5. The range in measured $\mathrm{pH}$ values for the UFA extracts is larger than those measured via the 1:1 sediment:water extraction technique, with a range of 7.51 to 8.28. In fact, none of the 1:1 sediment:water extract samples had $\mathrm{pH}$ values above 8 . Hanford sediments generally contain sufficient concentrations of carbonatebearing minerals to generate groundwater and pore water solutions in the $\mathrm{pH}$ range between 7.0 and 8.5. Therefore, the $\mathrm{pH}$ data generated using both techniques are consistent with prior results and expectations.

Comparison of the UFA extract EC data presented in Table 5.7 with that generated via the 1:1 sediment:water extracts (Table 5.2) yields mixed results (Figure 5.2). In most cases, the UFA extract EC data fall between the as-measured values in the 1:1 sediment:water extracts and the pore water-corrected values. In every case but that for sample C5708-56.5, the UFA extract EC result was $30 \%$ or more less than the pore water corrected value, and in most cases, the numbers differed by at least a factor of two. The extreme difference between the two EC values was found in sample B1PL53-3, which had very low residual moisture content. With these data, it seems conclusive that the pore water-corrected values associated with this sample will be systematically biased high due to an erroneously low field moisture content measurement. Excluding this data point, the two methods differed by an average factor of 2.18, and the UFA extract results were always lower than the pore water-corrected water extract data. This implies that the process of drying the samples and then extracting them using the 1:1 sediment:water technique has resulted in at least partial dissolution of the solids not initially present within the entrained

pore water. Further, the difference of approximately a factor of 2 between the water and UFA extracts is similar to findings reported by Serne et al. (2002b, 2002c, 2002d, 2002e, 2002f). 
Table 5.7. $\mathrm{pH}$ and EC Data in UFA Extracts of Sediments from Well 399-2-5

\begin{tabular}{cccc}
\hline $\begin{array}{c}\text { Sample Name } \\
\text { (HEIS ID) }\end{array}$ & $\begin{array}{c}\text { Sample Mid Depth } \\
\text { (ft bgs) }\end{array}$ & $\mathrm{pH}$ & $\begin{array}{c}\mathrm{EC} \\
(\mathrm{mS} / \mathrm{cm})\end{array}$ \\
\hline B1PL48-1 UFA & 26.6 & 7.67 & $8.18 \mathrm{E}-01$ \\
B1PL50-2 UFA & 35.3 & 7.92 & $5.42 \mathrm{E}-01$ \\
B1PL50-1 UFA & 36.3 & 8.06 & $5.96 \mathrm{E}-01$ \\
B1PL52-1 UFA & 47.0 & 7.51 & $4.17 \mathrm{E}-01$ \\
B1PL53-3 UFA & 50.0 & 7.93 & $3.95 \mathrm{E}-01$ \\
C5708-56.5 UFA & 56.5 & 8.08 & $4.33 \mathrm{E}-01$ \\
B1PL54-2 UFA & 74.3 & 7.80 & $1.91 \mathrm{E}+00$ \\
B1PL54-1 UFA & 74.8 & 8.28 & $1.25 \mathrm{E}+00$ \\
\hline
\end{tabular}

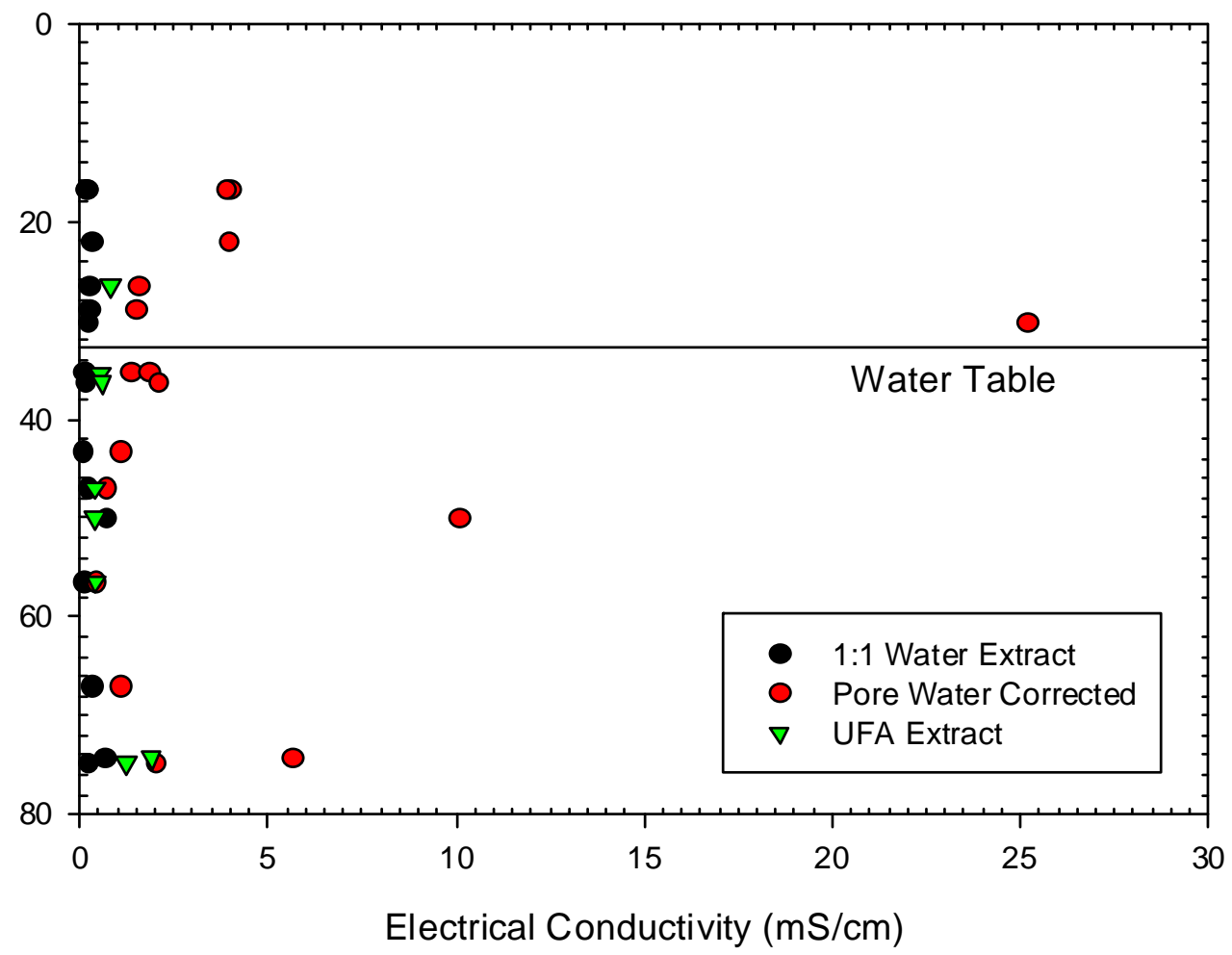

Figure 5.2. EC Measurements of Sediments from Well 399-2-5

\subsubsection{Major Anions and Cations}

Table 5.8 contains the major anions and Table 5.9 the major cations in UFA extracts, as well as the corresponding pore water-corrected 1:1 sediment:water extract data for sediments from well 399-2-5. All of the data have been converted to units of $\mathrm{meq} / \mathrm{L}$ so that charge balance comparisons (anions versus cations) could be made. Only three samples from well 399-2-5 contain complementary UFA and pore water-corrected sediment:water extract data; B1PL48-1, C5708-56.5, and B1PL54-1. Comparison of the two sets of anion data reported in Table 5.8 leads to mixed results. Two of the three samples analyzed (C5708-56.5 and B1PL54-1) contained consistent concentrations of dissolved anions in the UFA versus 
sediment:water extracts. The total concentrations of dissolved anions varied by 12 and $14 \%$ in samples C5708-56.5 and B1PL54-1, respectively. Conversely, the water extract of sample B1PL48-1 contained significantly more dissolved anions than the UFA extract (percent difference of $47 \%$ between the two samples). The dominant dissolved anion in both types of extracts was sulfate, followed by alkalinity (bicarbonate), nitrate, and chloride. Evaluation of each specific anion in the two types of extracts did not yield a consistent trend. For example, sulfate had a difference of $55 \%$ between the two extracts, alkalinity was different by $82 \%$, nitrate by $31 \%$, and chloride was most similar with a difference of only $13 \%$. If these samples had been processed using the same technique, duplicate analyses of the same sample should agree within $\pm 35 \%$; the $\pm 35 \%$ agreement allows for some variability due to sample heterogeneity. In the case of a water extract vs. an UFA extract, considerably different conditions occur. A 1:1 sediment:water extract uses a large volume of deionized water to extract the entrapped pore water from the sediment. Conversely, a UFA extract results in the direct removal of the entrapped pore water using UFA with no dilution. In cases where the dissolved constituents vary between water extracts and UFA extracts, it is difficult to definitively identify the cause. Given the differences between the two techniques, sample heterogeneity is still possible. However, another probable explanation is that in addition to removing the entrapped pore water, the water extract actually dissolved some of the host sediment. This would result in the case observed with sample B1PL48-1, in which the water extract resulted in a more saline sample in comparison to the UFA extract. Additionally, alkalinity (which was significantly elevated in the water vs. UFA extract), would be particularly susceptible to dissolution via the addition of deionized water, which has a slightly acidic $\mathrm{pH}$ that would lead to the dissolution of carbonate minerals in the sediment.

Table 5.8. Major Anions in UFA Extracts and Pore Water Corrected 1:1 Sediment:Water Extracts of Sediments from Well 399-2-5 ${ }^{\text {(a) }}$

\begin{tabular}{|c|c|c|c|c|c|c|c|}
\hline $\begin{array}{l}\text { Sample Name } \\
\text { (HEIS ID) }\end{array}$ & $\begin{array}{l}\text { Sample } \\
\text { Mid Depth } \\
\text { (ft bgs) }\end{array}$ & $\begin{array}{l}\text { Fluoride } \\
\text { (meq/L) }\end{array}$ & $\begin{array}{l}\text { Chloride } \\
\text { (meq/L) }\end{array}$ & $\begin{array}{l}\text { Nitrate } \\
(\mathrm{meq} / \mathrm{L})\end{array}$ & $\begin{array}{l}\text { Sulfate } \\
(\mathrm{meq} / \mathrm{L})\end{array}$ & $\begin{array}{l}\text { Phosphate } \\
\text { (meq/L) }\end{array}$ & $\begin{array}{c}\text { Alkalinity } \\
\text { as } \mathrm{CO}_{3} \\
(\mathrm{meq} / \mathrm{L})\end{array}$ \\
\hline \multicolumn{8}{|c|}{ Pore Water Corrected Water Extract Data } \\
\hline B1PL48-1 WE & 26.6 & $2.24 \mathrm{E}-01$ & $2.56 \mathrm{E}+00$ & $3.53 \mathrm{E}+00$ & $5.81 \mathrm{E}+00$ & $<2.86 \mathrm{E}-01$ & $2.93 \mathrm{E}+00$ \\
\hline B1PL50-2 WE & 35.3 & $3.66 \mathrm{E}-01$ & $9.05 \mathrm{E}-01$ & $<1.85 \mathrm{E}-01$ & $4.95 \mathrm{E}+00$ & $<5.43 \mathrm{E}-01$ & $7.66 \mathrm{E}+00$ \\
\hline C5708-56.5 WE & 56.5 & $8.73 \mathrm{E}-02$ & 4.66E-01 & 2.97E-01 & $1.01 \mathrm{E}+00$ & $<1.77 \mathrm{E}-01$ & $2.62 \mathrm{E}+00$ \\
\hline B1PL54-1 WE & 74.8 & $1.72 \mathrm{E}-01$ & $3.15 \mathrm{E}-01$ & $<1.45 \mathrm{E}-01$ & $1.06 \mathrm{E}+01$ & $<4.26 \mathrm{E}-01$ & $8.21 \mathrm{E}+00$ \\
\hline \multicolumn{8}{|c|}{ UFA Extract Data } \\
\hline B1PL48-1 UFA & 26.6 & $<1.05 \mathrm{E}-01$ & $2.25 \mathrm{E}+00$ & $2.58 \mathrm{E}+00$ & $3.29 \mathrm{E}+00$ & $<4.74 \mathrm{E}-01$ & $1.22 \mathrm{E}+00$ \\
\hline B1PL50-2 UFA & 35.3 & $\begin{array}{c}\text { Not } \\
\text { Measured }\end{array}$ & $\begin{array}{c}\text { Not } \\
\text { Measured }\end{array}$ & $\begin{array}{c}\text { Not } \\
\text { Measured }\end{array}$ & $\begin{array}{c}\text { Not } \\
\text { Measured }\end{array}$ & $\begin{array}{c}\text { Not } \\
\text { Measured }\end{array}$ & $8.66 \mathrm{E}-01$ \\
\hline C5708-56.5 UFA & 56.5 & $<1.05 \mathrm{E}-01$ & $9.70 \mathrm{E}-01$ & $7.01 \mathrm{E}-01$ & $1.48 \mathrm{E}+00$ & $<4.74 \mathrm{E}-01$ & $1.90 \mathrm{E}+00$ \\
\hline B1PL54-1 UFA & 74.8 & $<1.05 \mathrm{E}-01$ & $2.15 \mathrm{E}-01$ & $<1.61 \mathrm{E}-01$ & $1.41 \mathrm{E}+01$ & $<4.74 \mathrm{E}-01$ & $2.43 \mathrm{E}+00$ \\
\hline
\end{tabular}

The 1:1 sediment-to-water and UFA-extractable cation data in Table 5.9 exhibit trends nearly identical to the anion results in Table 5.8. Specifically, there was little difference between the total concentrations of dissolved cations in water versus UFA extracts for samples C5708-56.5 and B1PL54-1, with percent differences of only 12 and $10 \%$, respectively. Like the anion results, the water extract of sample B1PL48-1 contained significantly more dissolved cations than the UFA extract (percent difference of 53\% between the two samples). The dominant dissolved cation in both extracts was calcium, followed by sodium, magnesium, potassium, and strontium. Similar to the anion data, evaluation of each specific 
cation in the two extracts did not yield a consistent trend. For example, calcium and magnesium had percent differences of approximately $35 \%$ in the two extracts, while sodium and potassium varied by 92 and $97 \%$, respectively. Strontium, another divalent cation present in Hanford sediments, varied by approximately $44 \%$ between the two extracts. The divalent cations calcium and magnesium are typically the dominant water-extractable cations in Hanford formation and Ringold Formation sediments that have not been contacted by the Hanford process waste stream. Thus it is not surprising that they had the closest concentrations between the extracts. The monovalent cation sodium is ubiquitous in Hanford waste streams. The presence of more sodium than magnesium in this sample could be a result of waste disposed to the SPP, in which case its concentration in the sample should be more heterogeneous than the naturally present constituents.

Table 5.9. Major Cations in UFA Extracts and Pore Water-Corrected 1:1 Sediment:Water Extracts of Sediments from Well 399-2-5

\begin{tabular}{|c|c|c|c|c|c|c|}
\hline $\begin{array}{c}\text { Sample Name } \\
\text { (HEIS ID) }\end{array}$ & $\begin{array}{l}\text { Sample } \\
\text { Mid Depth } \\
\text { (ft bgs) }\end{array}$ & $\begin{array}{l}\text { Calcium } \\
(\mathrm{meq} / \mathrm{L})\end{array}$ & $\begin{array}{c}\text { Potassium } \\
(\mathrm{meq} / \mathrm{L})\end{array}$ & $\begin{array}{c}\text { Magnesium } \\
(\mathrm{meq} / \mathrm{L})\end{array}$ & $\begin{array}{c}\text { Strontium( } \\
\text { meq/L) }\end{array}$ & $\begin{array}{l}\text { Sodium } \\
(\mathrm{meq} / \mathrm{L})\end{array}$ \\
\hline \multicolumn{7}{|c|}{ Pore Water Corrected Water Extract Data } \\
\hline B1PL48-1 WE & 26.6 & $6.57 \mathrm{E}+00$ & $6.26 \mathrm{E}-01$ & $2.03 \mathrm{E}+00$ & $1.49 \mathrm{E}-02$ & $4.18 \mathrm{E}+00$ \\
\hline B1PL50-2 WE & 35.3 & $4.65 \mathrm{E}+00$ & $8.21 \mathrm{E}-01$ & $1.67 \mathrm{E}+00$ & $1.01 \mathrm{E}-02$ & $4.17 \mathrm{E}+00$ \\
\hline C5708-56.5 WE & 56.5 & $1.39 \mathrm{E}+00$ & $3.85 \mathrm{E}-01$ & $4.85 \mathrm{E}-01$ & $3.01 \mathrm{E}-03$ & $1.36 \mathrm{E}+00$ \\
\hline B1PL54-1 WE & 74.8 & $7.50 \mathrm{E}+00$ & $1.85 \mathrm{E}+00$ & $3.23 \mathrm{E}+00$ & $1.78 \mathrm{E}-02$ & $4.41 \mathrm{E}+00$ \\
\hline \multicolumn{7}{|c|}{ UFA Extract Data } \\
\hline B1PL48-1 UFA & 26.6 & $4.60 \mathrm{E}+00$ & $2.17 \mathrm{E}-01$ & $1.43 \mathrm{E}+00$ & $9.52 \mathrm{E}-03$ & $1.55 \mathrm{E}+00$ \\
\hline B1PL50-2 UFA & 35.3 & $\begin{array}{c}\text { Not } \\
\text { Measured }\end{array}$ & $\begin{array}{c}\text { Not } \\
\text { Measured }\end{array}$ & $\begin{array}{c}\text { Not } \\
\text { Measured }\end{array}$ & $\begin{array}{c}\text { Not } \\
\text { Measured }\end{array}$ & $\begin{array}{c}\text { Not } \\
\text { Measured }\end{array}$ \\
\hline C5708-56.5 UFA & 56.5 & $2.08 \mathrm{E}+00$ & $1.92 \mathrm{E}-01$ & $7.40 \mathrm{E}-01$ & $4.66 \mathrm{E}-03$ & $1.08 \mathrm{E}+00$ \\
\hline B1PL54-1 UFA & 74.8 & $9.22 \mathrm{E}+00$ & $4.58 \mathrm{E}-01$ & $3.81 \mathrm{E}+00$ & $2.18 \mathrm{E}-02$ & $1.89 \mathrm{E}+00$ \\
\hline
\end{tabular}

A review of the charge balance between anions and cations in the 1:1 water and UFA extracts of samples from well 399-2-5 indicated that overall the samples from both data sets were slightly overcharged with respect to anions. The percent difference in charge balance ranged from 8.4 to $21.2 \%$, with an average charge imbalance of $16.1 \%$. In every case, the total charge associated with the anions exceeded that of the cations. There was no remarkable difference between the water and UFA extract samples; results from both types of extracts were out of balance by $20 \%$ for at least one sample analyzed. Given this, the difference in total charge between anions and cations cannot be attributed to dissolution of host sediment during the 1:1 sediment:water extract; instead, differences may be due to an effect occurring during sample storage. Perhaps $\mathrm{CO}_{2}(\mathrm{~g})$ dissolves into the pore water during sample storage, resulting in higher dissolved carbonate results in the extracts.

Table 5.10 contains uranium-238 data from both the 1:1 sediment to water and UFA extracts. As the primary constituent of concern for this study, more data are available for comparing uranium-238 concentrations in the two extracts than any other constituent. Based on the major anion and cation data in Tables 5.8 and 5.9, the water extracts almost always had higher dissolved salt loads than the UFA extracts (likely due to the dissolution of carbonate or amorphous coatings). Conversely, for the eight samples for which comparative data exist, all but two had higher uranium-238 concentrations in the UFA extracts than in the 1:1 sediment:water extracts. Further, of the six samples with higher UFA extractable uranium-238, five had percent differences of approximately $100 \%$ or greater. Samples B1PL50-1 and B1PL50-2 were 
the only samples to have consistent water and UFA extractable uranium-238 concentration, with differences of 3.5 and $4.8 \%$, respectively. No clear trend can be elucidated from the data in Table 5.10. For example, agreement between the water-extractable uranium data generated from the two extracts is not concentration dependent because equally poor agreement was observed in the most (B1PL54-1) and least (C5708-56.5) contaminated samples analyzed. Additionally, the phenomenon does not appear to be stratigraphically related because samples collected within the Hanford formation and Ringold Formation both had statistically significant differences between water and UFA extractable uranium-238. Based on these data, it appears that a process could be leading to the sequestration of uranium during the storage of sediment samples or potentially during the 1:1 sediment:water extract process. Another possibility is that the partially wet sediments have a very thin double layer of cations in the film around the particles that neutralizes the net negative charge on the particles. Just outside this cation-dominated double layer is the more readily removable anion-rich charge compensating film of water. Because the UFA uses UFA to extract pore water from the sediments, it can spin out the anion-rich layer of water, but not the cationdominated double layer thin film surrounding the sediment particles. Another artifact that cannot be reconciled is that the higher alkalinity concentrations measured in the water extracts should have led to higher overall uranium concentrations because the carbonate would complex with the uranium, increasing its solubility. While the root cause remains unknown at this time, it is clear that uranium is not behaving as expected in the water versus UFA extracts.

Table 5.10. Uranium Concentrations in UFA Extracts and Pore Water-Corrected 1:1 Sediment:Water Extracts of Sediments from Well 399-2-5

\begin{tabular}{lcc}
\hline $\begin{array}{c}\text { Sample Name } \\
(\text { HEIS ID) }\end{array}$ & $\begin{array}{c}\text { Sample Mid Depth } \\
(\mathrm{ft} b g s)\end{array}$ & $\begin{array}{c}\text { Uranium-238 } \\
(\mu \mathrm{g} / \mathrm{L})\end{array}$ \\
\hline \multicolumn{1}{c}{ Pore Water Corrected Water Extract Data } \\
\hline B1PL48-1 & 26.6 & $1.21 \mathrm{E}+01$ \\
B1PL50-2 & 35.3 & $3.01 \mathrm{E}+01$ \\
B1PL50-2 DUP & 35.3 & $2.08 \mathrm{E}+01$ \\
B1PL50-1 & 36.3 & $3.40 \mathrm{E}+01$ \\
B1PL52-1 & 47.0 & $1.53 \mathrm{E}+00$ \\
B1PL53-3 & 50.0 & $2.38 \mathrm{E}+00$ \\
C5708-56.5 & 56.5 & $5.94 \mathrm{E}-01$ \\
B1PL54-2 & 74.3 & $7.40 \mathrm{E}+01$ \\
B1PL54-1 & 74.8 & $7.51 \mathrm{E}+01$ \\
\hline \multicolumn{3}{c}{} \\
\hline B1PL48-1 UFA & UFA Extract Data \\
B1PL50-2 UFA & 26.6 & $5.41 \mathrm{E}+01$ \\
B1PL50-1 UFA & 35.3 & $2.87 \mathrm{E}+01$ \\
B1PL52-1 UFA & 36.3 & $3.52 \mathrm{E}+01$ \\
B1PL53-3 UFA & 47.0 & $9.56 \mathrm{E}+00$ \\
C5708-56.5 UFA & 50.0 & $1.56 \mathrm{E}+01$ \\
B1PL54-2 UFA & 56.5 & $5.81 \mathrm{E}+00$ \\
B1PL54-1 UFA & 74.3 & $4.14 \mathrm{E}+01$ \\
\hline
\end{tabular}

\subsection{4 $8 \mathrm{M}$ Nitric Acid-Extractable and Microwave-Assisted Digestible Concentrations of Uranium-238 in Sediments from Well 399-2-5}

Well 399-2-5 was drilled within the footprint of the 216 SPP; therefore, it was hypothesized that sediments retrieved during drilling would contain significant concentrations of contaminant uranium. While several samples contained elevated concentrations of water-extractable uranium (which has been 
attributed to contaminant uranium), a comparison of extraction techniques was performed to investigate the total concentration of uranium-238 in these samples. It is acknowledged that solely measuring uranium-238 does not take into account the other uranium isotopes that should be present in these samples; however, the total concentrations of uranium-235, uranium-234 (and possibly uranium-236) are expected to be sufficiently low that their contribution would add less than $1 \%$ to the total uranium mass calculation. As such, for the purpose of this report, the concentration of uranium-238 present in these samples is considered the same as total uranium on a mass basis.

Table 5.11 and Figure 5.3 plot the total acid-extractable and microwave-digestible uranium data (measured as $\mu \mathrm{g}$ uranium-238/g sediment on a dry weight basis) as a function of depth for sediments collected from well 399-2-5. Acid-extractable uranium concentrations ranged from a low of 0.346 to a maximum of $2.94 \mu \mathrm{g} / \mathrm{g}$. In comparison, the microwave digest method released more uranium from the sediments, from 1.15 to $5.50 \mu \mathrm{g} / \mathrm{g}$. In every case, the microwave digests contained higher uranium concentrations; in general, twice as much soluble uranium as the nitric acid extracts. This finding was not surprising because the microwave digest method results in complete sample dissolution, whereas the $8 \mathrm{M}$ nitric acid extract is less effective against recalcitrant minerals. It was a bit surprising that the maximum microwave-digestible uranium concentration measured in the sediments from well 399-2-5 was only 5.50 $\mu \mathrm{g} / \mathrm{g}$. While these samples clearly contained contaminant uranium, they certainly did not contain the inventory of uranium thought to be necessary to sustain the groundwater plume in the 300 Area aquifer. These results do not support the previous hypothesis and subsequent box model of contaminant uranium inventory in the 300 Area vadose zone, which estimated a large distribution of contaminant uranium in the vadose zone directly beneath effluent disposal facilities (Peterson et al. 2008a).

A comparison of the water-extractable versus acid-extractable and microwave digestible uranium concentrations can be used to calculate an equilibrium $\mathrm{K}_{d}$ (partition coefficient) for uranium. An equilibrium $K_{d}$ can be used to estimate the relative leachability of uranium in the 300 Area sediments, assuming that the 1:1 sediment:water extract acted solely as a mechanism to remove the entrapped pore water from the sediments. Again, although these samples were air-dried prior to performing the 1:1 sediment:water extract, it is reasonable to assume that the extract would have efficiently dissolved the constituents that precipitated upon drying of the samples. As mentioned previously, the assumption that none of the solid is dissolved during the water extraction process is simplistic. Therefore, the equilibrium $\mathrm{K}_{\mathrm{d}}$ values presented in Table 5.12 based on the water extract results could be biased low (i.e., predicting greater release from the sediment). However, the 1:1 sediment:water technique is the only valid method to estimate pore water chemistry for the sediments with very low extractable water content.

Table 5.11. Acid-Extractable and Microwave-Digestible Uranium in Sediments from Well 399-2-5

\begin{tabular}{lccc}
\hline $\begin{array}{c}\text { Sample Name } \\
(\text { HEIS ID) }\end{array}$ & $\begin{array}{c}\text { Sample Mid Depth } \\
(\mathrm{ft} \mathrm{bgs})\end{array}$ & $\begin{array}{c}\text { Acid-Extractable }{ }^{238} \mathrm{U} \\
(\mu \mathrm{g} / \mathrm{g})\end{array}$ & $\begin{array}{c}\text { Microwave-Digestible }{ }^{238} \mathrm{U} \\
(\mu \mathrm{g} / \mathrm{g})\end{array}$ \\
\hline B1PL46-1 & 16.8 & $6.95 \mathrm{E}-01$ & $1.96 \mathrm{E}+00$ \\
B1PL47-1 & 22.1 & $1.30 \mathrm{E}+00$ & $2.26 \mathrm{E}+00$ \\
B1PL48-1 & 26.6 & $2.94 \mathrm{E}+00$ & $4.08 \mathrm{E}+00$ \\
B1PL49-1 & 30.2 & $2.35 \mathrm{E}+00$ & $5.50 \mathrm{E}+00$ \\
B1PL50-2 & 35.3 & $6.62 \mathrm{E}-01$ & $2.04 \mathrm{E}+00$ \\
B1PL51-1 & 43.3 & $9.11 \mathrm{E}-01$ & $1.68 \mathrm{E}+00$ \\
C5708-56.5 & 56.5 & $5.51 \mathrm{E}-01$ & $2.58 \mathrm{E}+00$ \\
C5708-67 & 67.0 & $3.56 \mathrm{E}-01$ & $1.22 \mathrm{E}+00$ \\
C5708-67 DUP & 67.0 & $3.46 \mathrm{E}-01$ & $1.15 \mathrm{E}+00$ \\
B1PL54-1 & 74.8 & $5.80 \mathrm{E}-01$ & $1.86 \mathrm{E}+00$ \\
\hline
\end{tabular}




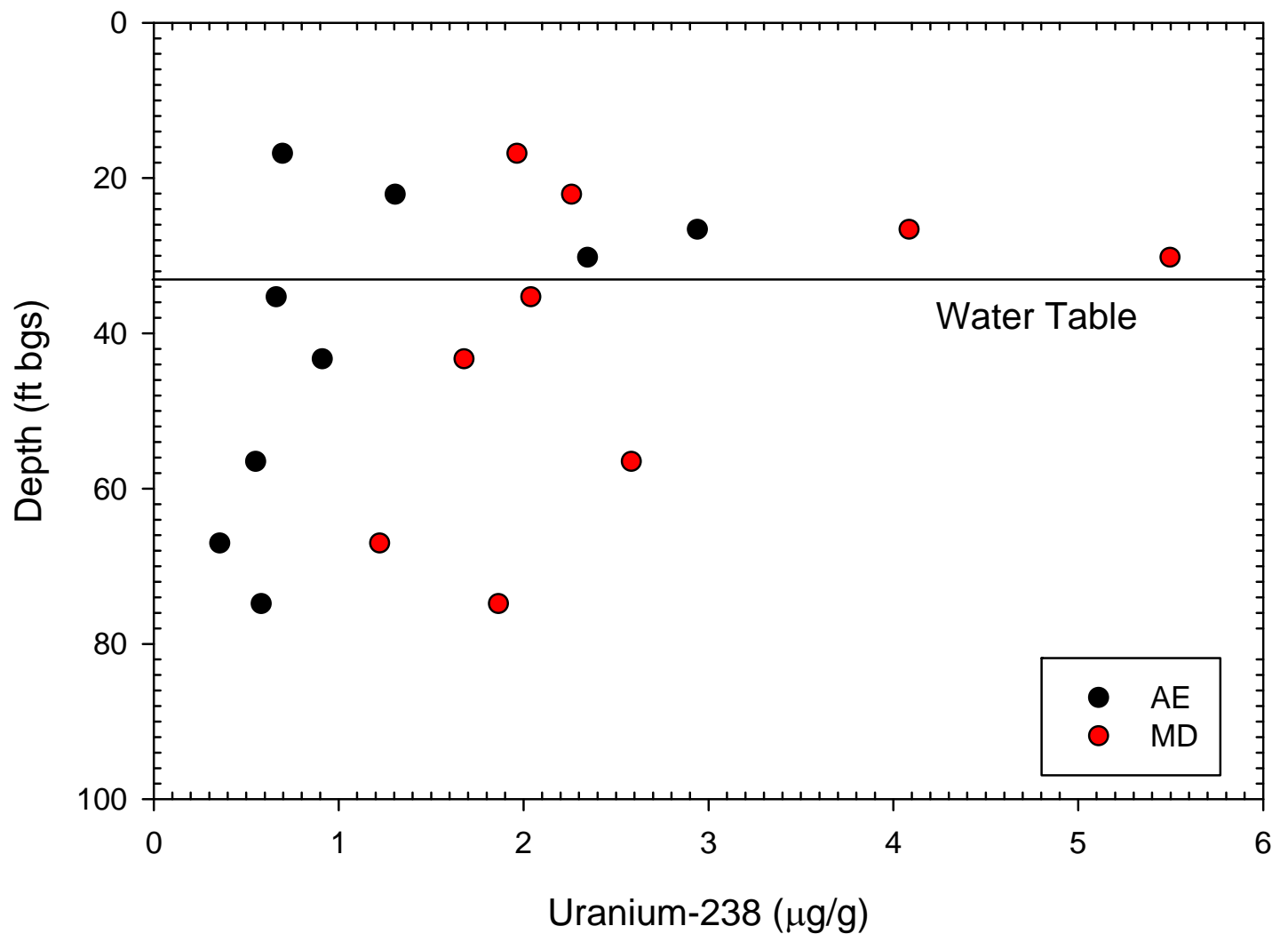

Figure 5.3. Concentration of Acid-Extractable (AE) and Microwave Digestible (MD) Uranium-238 in Sediments from Well 399-2-5

Table 5.12. Equilibrium $K_{d}$ based on Water-Extractable (WE) Versus Acid-Extractable (AE) or Microwave Digestible (MD) Uranium in Sediments from Well 399-2-5

\begin{tabular}{lccc}
\hline $\begin{array}{c}\text { Sample Name } \\
\text { (HEIS ID) }\end{array}$ & $\begin{array}{c}\text { Sample Mid Depth } \\
(\mathrm{ft} \text { bgs })\end{array}$ & $\begin{array}{c}\text { Equilibrium } \mathrm{K}_{\mathrm{d}} \\
\text { based on WE and } \\
\text { AE Uranium-238 } \\
(\mathrm{ml} / \mathrm{g})\end{array}$ & $\begin{array}{c}\text { Equilibrium } \mathrm{K}_{\mathrm{d}} \\
\text { based on WE and } \\
\text { MD Uranium-238 } \\
(\mathrm{ml} / \mathrm{g})\end{array}$ \\
\hline B1PL46-1 & 16.8 & $2.92 \mathrm{E}+00$ & $8.33 \mathrm{E}+00$ \\
B1PL47-1 & 22.1 & $4.90 \mathrm{E}+00$ & $8.52 \mathrm{E}+00$ \\
B1PL48-1 & 26.6 & $1.62 \mathrm{E}+01$ & $2.26 \mathrm{E}+01$ \\
B1PL49-1 & 30.2 & $1.94 \mathrm{E}+02$ & $4.55 \mathrm{E}+02$ \\
B1PL50-2 & 35.3 & $2.69 \mathrm{E}-01$ & $8.47 \mathrm{E}-01$ \\
B1PL51-1 & 43.3 & $3.02 \mathrm{E}+01$ & $5.57 \mathrm{E}+01$ \\
C5708-56.5 & 56.5 & $1.69 \mathrm{E}+02$ & $7.94 \mathrm{E}+02$ \\
C5708-67 & 67.0 & $5.99 \mathrm{E}+02$ & $2.06 \mathrm{E}+03$ \\
B1PL54-1 & 74.8 & $4.07 \mathrm{E}+01$ & $1.35 \mathrm{E}+02$ \\
\hline
\end{tabular}


The predicted equilibrium $\mathrm{K}_{\mathrm{d}}$ values presented in Table 5.12 vary considerably, with a range of 0.269 to $599 \mathrm{~mL} / \mathrm{g}$ using the acid extracts versus a range of 0.847 to $2060 \mathrm{~mL} / \mathrm{g}$ using the microwave digests. Using the acid extract data, only one sample had an equilibrium uranium $\mathrm{K}_{\mathrm{d}}$ less than $2.9 \mathrm{~mL} / \mathrm{g}$; this was sample B1PL50-2 with a $\mathrm{K}_{\mathrm{d}}$ of $0.269 \mathrm{~mL} / \mathrm{g}$. In comparison, only one microwave-digested sample had an equilibrium $\mathrm{K}_{d}$ less than $8 \mathrm{~mL} / \mathrm{g}$; sample B1PL50-2 had a $\mathrm{K}_{\mathrm{d}}$ of $0.847 \mathrm{~mL} / \mathrm{g}$. According to these data, the uranium contamination present in the sediments has a relatively low solubility/leachability in deionized water (or low ionic strength mixed groundwater-river water) such that many cycles of equilibrium concentrations can be generated (assuming all of the easily leachable uranium in the pore water gets flushed out of the system) based on the existing inventory in the sediments. This premise is evaluated further in subsequent sections using pore waters retrieved via UFA as well as data garnered via the bicarbonate/carbonate leach tests.

\subsubsection{Labile Uranium Leach Test Results}

The concentration of labile (easily removable fraction, such as ion exchangeable or water soluble) uranium in the air-dried sediments was measured using a sodium bicarbonate/carbonate $\left(1.44 \times 10^{-2} \mathrm{M}\right.$ in $\mathrm{NaHCO}_{3}$ and $2.8 \times 10^{-3} \mathrm{M}$ in $\mathrm{Na}_{2} \mathrm{CO}_{3}$ ) mixed solution recommended by Kohler et al. (2004). The amount of uranium leached from the sediments was determined as a function of time, with sampling occurring after 1, 7, and 28 days of reaction. The goals of the time-dependent sampling are two-fold: time-based sampling enables one to determine if equilibrium (with respect to uranium solution concentrations) has been achieved in the reactors and it allows one to make general comments or conclusions about the rate of uranium release from the sediments. Table 5.13 and Figure 5.4 contain the data from the time-dependent labile uranium leach test; the data are reported as $\mu$ g uranium leached per gram of sediment on a dry weight basis. After consideration of the data, two primary trends become evident. The first trend involves a rather rapid release of uranium from the sediment. This initial release occurs within the first seven days of reaction and accounts for approximately $85 \%$ of the total amount of uranium removed from the sediments. The second trend can be characterized as a slow, continual release of uranium from the sediments. The kinetics of the second trend appear to extend beyond 28 days of reaction time, as steadystate uranium solution concentrations were not achieved for any of the samples analyzed. The two trends evident in this experiment are likely the results of two types of uranium being present in the sediments. The first type of uranium present, which readily leaches upon contact with the carbonate/bicarbonate solution, is likely present as an easily removable sorbed species. Conversely, the remaining uranium that can be characterized as having a very slow leach rate is likely present as discrete uranium-bearing minerals (Serne et al. 2002a) or as uranium microprecipitates that appear to be concentrated in fractures in feldspar crystals within granitic lithic fragments (Liu et al., 2004, 2006; McKinley et al. 2006). Another possible reason for the slow kinetically-controlled desorption of uranium could result from uranium sorbed to or physically entrapped within nanocrystalline iron oxide coatings that is more resistant to leaching, as proposed by Bond et al. (2008). 
Table 5.13. Labile Uranium Concentrations as a Function of Time in Sediments from Well 399-2-5

\begin{tabular}{lcccc}
\hline $\begin{array}{c}\text { Sample Name } \\
(\text { HEIS ID) }\end{array}$ & $\begin{array}{c}\text { Sample Mid Depth } \\
(\mathrm{ft} \mathrm{bgs})\end{array}$ & $\begin{array}{c}\text { Labile Uranium } \\
\text { Time }=1 \text { Day } \\
(\mu \mathrm{g} / \mathrm{g})\end{array}$ & $\begin{array}{c}\text { Labile Uranium } \\
\text { Time }=7 \text { Days } \\
(\mu \mathrm{g} / \mathrm{g})\end{array}$ & $\begin{array}{c}\text { Labile Uranium } \\
\text { Time }=28 \text { Days } \\
(\mu \mathrm{g} / \mathrm{g})\end{array}$ \\
\hline B1PL46-1 & 16.8 & $2.07 \mathrm{E}-01$ & $3.06 \mathrm{E}-01$ & $3.46 \mathrm{E}-01$ \\
B1PL47-1 & 22.1 & $4.74 \mathrm{E}-01$ & $6.94 \mathrm{E}-01$ & $7.96 \mathrm{E}-01$ \\
B1PL48-1 & 26.6 & $1.37 \mathrm{E}+00$ & $2.44 \mathrm{E}+00$ & $2.76 \mathrm{E}+00$ \\
B1PL49-1 & 30.2 & $8.07 \mathrm{E}-01$ & $1.42 \mathrm{E}+00$ & $1.66 \mathrm{E}+00$ \\
B1PL50-2 & 35.3 & $1.23 \mathrm{E}-01$ & $2.10 \mathrm{E}-01$ & $2.67 \mathrm{E}-01$ \\
B1PL51-1 & 43.3 & $1.03 \mathrm{E}-01$ & $1.64 \mathrm{E}-01$ & $2.00 \mathrm{E}-01$ \\
C5708-56.5 & 56.5 & $9.72 \mathrm{E}-02$ & $1.41 \mathrm{E}-01$ & $1.62 \mathrm{E}-01$ \\
C5708-67 & 67.0 & $7.61 \mathrm{E}-02$ & $1.05 \mathrm{E}-01$ & $1.28 \mathrm{E}-01$ \\
B1PL54-1 & 74.8 & $1.00 \mathrm{E}-01$ & $1.35 \mathrm{E}-01$ & $1.57 \mathrm{E}-01$ \\
\hline
\end{tabular}

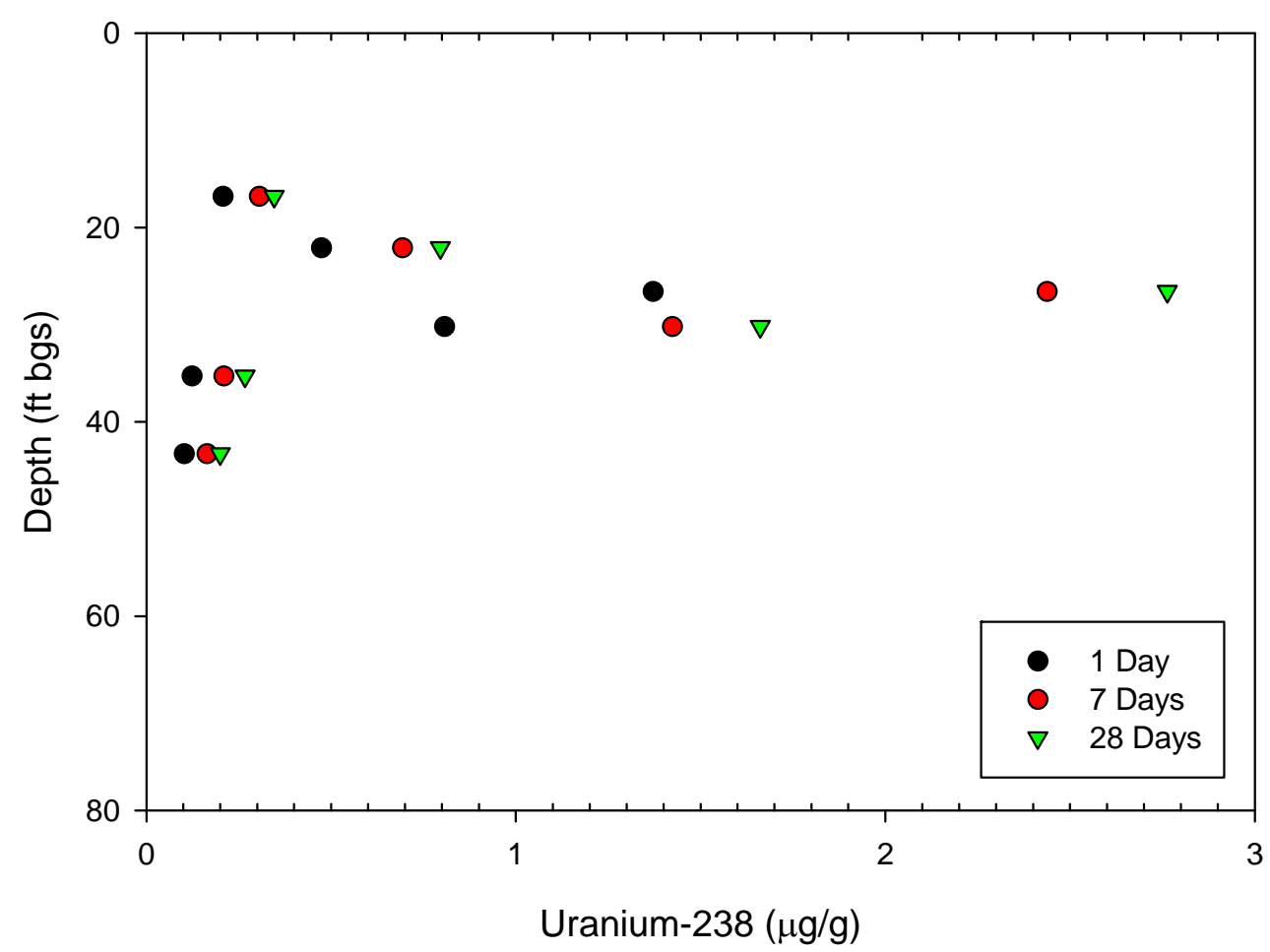

Figure 5.4. Concentration of Labile Uranium-238 in Sediments from Well 399-2-5 as Measured in Bicarbonate/Carbonate Batch Leach Tests

When the total amount of labile uranium (as measured during the 28-day sampling event) is used to calculate equilibrium $\mathrm{K}_{\mathrm{d}}$ values, a considerably different picture becomes evident. First of all, the calculated $\mathrm{K}_{\mathrm{d}}$ values are considerably lower, ranging from 0.143 to $272 \mathrm{~mL} / \mathrm{g}$. With the exception of sample B1PL48-1, all of the vadose zone sediment samples had $\mathrm{K}_{\mathrm{d}}$ values between 0.1 and $5 \mathrm{~mL} / \mathrm{g}$, much more consistent with values reported by other researchers that have characterized similar sediments (Serne et al. 2002a, Zachara et al. 2005, Williams et al. 2007). One surprising data point using this technique was for sample B1PL54-1, which had an equilibrium $\mathrm{K}_{\mathrm{d}}$ value of $1.98 \mathrm{~mL} / \mathrm{g}$. Sample B1PL54-1 was collected 
well below the water table and within the Ringold Formation in well 399-2-5, so it was not expected to contain much mobile uranium. Because the carbonate leach data have been used to generate these equilibrium $\mathrm{K}_{\mathrm{d}}$ values, the total uranium concentration is actually the total amount of uranium available for leaching (assuming the carbonate leach test removes only leachable uranium). Even so, it is obvious that the leachability of uranium varies dramatically among these sediments. Uranium in the vadose zone can be characterized as highly mobile $\left(\mathrm{K}_{\mathrm{d}}=0.143 \mathrm{~mL} / \mathrm{g}\right)$ to immobile $\left(\mathrm{K}_{\mathrm{d}}\right.$ value of $\left.229 \mathrm{~mL} / \mathrm{g}\right)$. Within the aquifer, uranium can be characterized as partially mobile $\left(\mathrm{K}_{d}\right.$ values of 2 to $\left.9 \mathrm{~mL} / \mathrm{g}\right)$ to immobile $\left(\mathrm{K}_{\mathrm{d}}\right.$ value of $272 \mathrm{~mL} / \mathrm{g}$ ). Given the range in calculated equilibrium $\mathrm{K}_{d}$ values (even using the leachable fraction of uranium as the total), it is clear that uranium will continue to slowly leach from these sediments for a substantial period of time.

Table 5.14. Equilibrium $\mathrm{K}_{\mathrm{d}}$ based on Labile Uranium 28 Day Sample Versus Water-Extractable (WE) Uranium in Sediments from Well 399-2-5

\begin{tabular}{lcc}
\hline $\begin{array}{c}\text { Sample Name } \\
\text { (HEIS ID) }\end{array}$ & $\begin{array}{c}\text { Sample Mid Depth } \\
\text { (ft bgs) }\end{array}$ & $\begin{array}{c}\text { Equilibrium } \mathrm{K}_{\mathrm{d}} \text { based on } \\
\text { 28-Day Sample and WE } \\
\text { Uranium-238 } \\
(\mathrm{mL} / \mathrm{g})\end{array}$ \\
\hline B1PL46-1 & 16.8 & $1.43 \mathrm{E}-01$ \\
B1PL47-1 & 22.1 & $4.34 \mathrm{E}+00$ \\
B1PL48-1 & 26.6 & $2.29 \mathrm{E}+02$ \\
B1PL49-1 & 30.2 & $6.89 \mathrm{E}-01$ \\
B1PL50-2 & 35.3 & $8.79 \mathrm{E}+00$ \\
B1PL51-1 & 43.3 & $6.14 \mathrm{E}+01$ \\
C5708-56.5 & 56.5 & $2.72 \mathrm{E}+02$ \\
C5708-67 & 67.0 & $1.49 \mathrm{E}+01$ \\
B1PL54-1 & 74.8 & $1.98 \mathrm{E}+00$ \\
\hline
\end{tabular}

\subsubsection{Total Carbon, Calcium Carbonate, and Organic Carbon Content of Sediment from Well 399-2-5}

Data from the total carbon, inorganic carbon, and organic carbon (calculated by difference) contents of the sediments collected during the drilling of well 399-2-5 are shown in Table 5.15. Inorganic carbon was not quantified in any of the samples from well 399-2-5; the estimated quantification limit ranged from $7.26 \mathrm{E}-03$ to $4.08 \mathrm{E}-02 \mathrm{wt} \%$ (the detection limit for inorganic carbon is slightly higher in the present study than reported in Williams et al. [2007] due to changes in the analytical method). Total carbon concentrations in the samples ranged from $2.45 \mathrm{E}-02$ to $1.38 \mathrm{E}-01 \mathrm{wt} \%$. Because inorganic carbon was not detected in these samples above the limit of quantification, the signal measured as total carbon has been entirely attributed to organic carbon. The concentrations of organic carbon measured in these samples compare well with those measured in boreholes C4999, C5000, C5001, and C5002, which all contained subpercent levels of organic carbon (Williams et al. 2007). 
Table 5.15. Total, Inorganic, and Organic Carbon Content of Sediments from Well 399-2-5

\begin{tabular}{lcccc}
\hline $\begin{array}{c}\text { Sample Name } \\
\text { (HEIS ID) }\end{array}$ & $\begin{array}{c}\text { Sample } \\
\text { Mid Depth } \\
\text { (ft bgs) }\end{array}$ & $\begin{array}{c}\text { Total } \\
\text { Carbon } \\
(\%)\end{array}$ & $\begin{array}{c}\text { Inorganic } \\
\text { Carbon } \\
(\%)\end{array}$ & $\begin{array}{c}\text { Organic } \\
\text { Carbon } \\
\text { (by difference) }\end{array}$ \\
\hline B1PL46-1 & 16.8 & $9.61 \mathrm{E}-02$ & $<1.04 \mathrm{E}-02$ & $9.61 \mathrm{E}-02$ \\
B1PL47-1 & 22.1 & $7.09 \mathrm{E}-02$ & $<1.41 \mathrm{E}-02$ & $7.09 \mathrm{E}-02$ \\
B1PL48-1 & 26.6 & $1.13 \mathrm{E}-01$ & $<8.85 \mathrm{E}-03$ & $1.13 \mathrm{E}-01$ \\
B1PL49-1 & 30.2 & $1.38 \mathrm{E}-01$ & $<7.26 \mathrm{E}-03$ & $1.38 \mathrm{E}-01$ \\
B1PL50-2 & 35.3 & $4.89 \mathrm{E}-02$ & $<2.04 \mathrm{E}-02$ & $4.89 \mathrm{E}-02$ \\
B1PL51-1 & 43.3 & $4.46 \mathrm{E}-02$ & $<2.24 \mathrm{E}-02$ & $4.46 \mathrm{E}-02$ \\
C5708-56.5 & 56.5 & $2.64 \mathrm{E}-02$ & $<3.79 \mathrm{E}-02$ & $2.64 \mathrm{E}-02$ \\
C5708-67 & 67.0 & $2.61 \mathrm{E}-02$ & $<3.83 \mathrm{E}-02$ & $2.61 \mathrm{E}-02$ \\
C5708-67 DUP & 67.0 & $2.45 \mathrm{E}-02$ & $<4.08 \mathrm{E}-02$ & $2.45 \mathrm{E}-02$ \\
B1PL54-1 & 74.8 & $7.14 \mathrm{E}-02$ & $<1.40 \mathrm{E}-02$ & $7.14 \mathrm{E}-02$ \\
\hline
\end{tabular}

\subsubsection{Analysis of Groundwater Samples from Well 399-2-5}

Groundwater samples analyzed by WSCF are presented in Tables 5.16 through 5.17 in units of meq/L to facilitate comparison to the UFA extract and 1:1 sediment:water pore water corrected data presented earlier. The groundwater samples had an average dissolved anion content of $3.87 \mathrm{meq} / \mathrm{L}$. The primary anionic species in the groundwater samples was alkalinity (bicarbonate), with a range of 2.6 to $3.4 \mathrm{meq} / \mathrm{L}$. The remaining negative charge came from sulfate, chloride, and nitrate (note that the groundwater samples were analyzed for fewer elements than the water and UFA extract samples). The anionic charge in the groundwater samples was primarily balanced by calcium (average concentration of $1.68 \mathrm{meq} / \mathrm{L}$ ), with lesser amounts of sodium, magnesium, potassium, and strontium. Overall, the charge balance between anions and cations was quite good. The percent difference between dissolved anions and cations in the groundwater samples varied from 0.4 to $5.7 \%$, indicating that while WSCF analyzed the groundwater samples for fewer anions, their analysis has captured the major constituents in the samples.

Table 5.16. Major Anions in Groundwater Samples from Well 399-2-5

\begin{tabular}{|c|c|c|c|c|c|}
\hline $\begin{array}{l}\text { Sample Name } \\
\text { (HEIS ID) }\end{array}$ & $\begin{array}{c}\text { Sample } \\
\text { Mid } \\
\text { Depth } \\
\text { (ft bgs) }\end{array}$ & $\begin{array}{l}\text { Chloride } \\
\text { (meq/L) }\end{array}$ & $\begin{array}{l}\text { Nitrate } \\
(\mathrm{meq} / \mathrm{L})\end{array}$ & $\begin{array}{c}\text { Sulfate } \\
(\mathrm{meq} / \mathrm{L})\end{array}$ & $\begin{array}{l}\text { Alkalinit } \\
\text { y as } \mathrm{CO}_{3} \\
{ }^{2-}(\mathrm{meq} / \mathrm{L})\end{array}$ \\
\hline B1PL94 & 36.3 & $5.19 \mathrm{E}-01$ & $4.48 \mathrm{E}-01$ & $1.15 \mathrm{E}+00$ & $2.80 \mathrm{E}+00$ \\
\hline B1PL95 & 48.0 & $5.33 \mathrm{E}-01$ & $4.65 \mathrm{E}-01$ & $1.13 \mathrm{E}+00$ & $2.60 \mathrm{E}+00$ \\
\hline B1PL96 & 67.5 & $1.48 \mathrm{E}-01$ & $1.92 \mathrm{E}-02$ & 7.73E-02 & $2.60 \mathrm{E}+00$ \\
\hline B1PL98 & 72.5 & $1.23 \mathrm{E}-01$ & $3.56 \mathrm{E}-04$ & $3.10 \mathrm{E}-03$ & $2.60 \mathrm{E}+00$ \\
\hline B1PL99 & 85.5 & $1.49 \mathrm{E}-01$ & $3.56 \mathrm{E}-04$ & $2.83 \mathrm{E}-03$ & $2.80 \mathrm{E}+00$ \\
\hline B1PLB0 & 107.5 & $2.13 \mathrm{E}-01$ & $3.56 \mathrm{E}-04$ & $1.22 \mathrm{E}-01$ & $3.00 \mathrm{E}+00$ \\
\hline B1PLB1 & 125.0 & $2.47 \mathrm{E}-01$ & $3.56 \mathrm{E}-04$ & $7.88 \mathrm{E}-02$ & $3.40 \mathrm{E}+00$ \\
\hline
\end{tabular}


Table 5.17. Major Cations in Groundwater Samples from Well 399-2-5

\begin{tabular}{lccccc}
\hline $\begin{array}{c}\text { Sample Name } \\
\text { (HEIS ID) }\end{array}$ & $\begin{array}{c}\text { Sample } \\
\text { Mid Depth } \\
\text { (ft bgs) }\end{array}$ & $\begin{array}{c}\text { Calcium } \\
\text { (meq/L) }\end{array}$ & $\begin{array}{c}\text { Potassium } \\
(\mathrm{meq} / \mathrm{L})\end{array}$ & $\begin{array}{c}\text { Magnesium } \\
\text { (meq/L) }\end{array}$ & $\begin{array}{c}\text { Sodium } \\
(\mathrm{meq} / \mathrm{L})\end{array}$ \\
\hline B1PL94 & 36.3 & $2.84 \mathrm{E}+00$ & $1.46 \mathrm{E}-01$ & $9.22 \mathrm{E}-01$ & $9.83 \mathrm{E}-01$ \\
B1PL95 & 48.0 & $2.61 \mathrm{E}+00$ & $1.41 \mathrm{E}-01$ & $9.05 \mathrm{E}-01$ & $1.01 \mathrm{E}+00$ \\
B1PL96 & 67.5 & $1.45 \mathrm{E}+00$ & $1.31 \mathrm{E}-01$ & $5.55 \mathrm{E}-01$ & $5.61 \mathrm{E}-01$ \\
B1PL98 & 72.5 & $1.35 \mathrm{E}+00$ & $1.30 \mathrm{E}-01$ & $5.60 \mathrm{E}-01$ & $6.09 \mathrm{E}-01$ \\
B1PL99 & 85.5 & $1.35 \mathrm{E}+00$ & $1.47 \mathrm{E}-01$ & $6.04 \mathrm{E}-01$ & $9.26 \mathrm{E}-01$ \\
B1PLB0 & 107.5 & $1.12 \mathrm{E}+00$ & $2.16 \mathrm{E}-01$ & $5.88 \mathrm{E}-01$ & $1.23 \mathrm{E}+00$ \\
B1PLB1 & 125.0 & $1.03 \mathrm{E}+00$ & $2.15 \mathrm{E}-01$ & $5.79 \mathrm{E}-01$ & $1.71 \mathrm{E}+00$ \\
\hline
\end{tabular}

Comparison of the total concentration of anions and cations in the groundwater samples and those measured in the water and UFA extracts identified that the groundwater samples were much more dilute than either of the two types of sediment extracts. Sediment samples from the depths at which groundwater data are available were not necessarily analyzed as part of this exercise; however, sufficient water and UFA extract data versus groundwater analytical results exist to make some general interpretations. First, the groundwater samples are only about $30 \%$ as concentrated as the water extract samples, and approximately $35 \%$ as concentrated as the UFA extracts. Second, sulfate is the anion with the largest discrepancy between water and UFA extracts versus groundwater samples. Calcium is the corresponding cation with the poorest agreement among the datasets, indicating that the dissolution of a calcium sulfate mineral (such as gypsum) could be altering the chemical composition of the 1:1 sediment:water and UFA extracts. Finally, the concentrations of carbonate varied by $46 \%$ in the $1: 1$ sediment:water extracts versus groundwater samples, which could be an indication of the dissolution of calcite (or calcium carbonate coatings) in the water extract samples.

The concentration of uranium-238 in the groundwater samples, as measured by WSCF, is reported in Table 5.18. The majority of the contaminant uranium in the aquifer resides in the gravel-dominated Hanford formation rather than in the finer-grained Ringold Formation. The two groundwater samples collected within the Hanford formation in well 399-2-5 had uranium-238 concentrations of 70.4 and $40.0 \mu \mathrm{g} / \mathrm{L}$. In comparison, dissolved uranium concentrations in the Ringold Formation ranged from 2.34 to less than $0.1 \mu \mathrm{g} / \mathrm{L}$, with a generally decreasing trend as a function of depth within the aquifer.

Of all the sediment samples taken through the water and UFA extraction process, only one was retrieved from the same depth at which groundwater data are available (36.3 ft bgs). However, two additional sediment samples were collected in proximity or adjacent to depths at which groundwater was collected (47.0 and $74.3 \mathrm{ft}$ bgs). Comparison of these data with those generated via analysis of the groundwater samples resulted in some surprising findings. Deionized water and UFA extracts of both sediments collected within the Hanford formation contained significantly less uranium than groundwater samples collected at the same depths. As shown in Table 5.10, the sediment collected from $36.3 \mathrm{ft} \mathrm{bgs}$ contained 1:1 sediment:water and UFA-extractable uranium concentrations of 34.0 and $35.2 \mu \mathrm{g} / \mathrm{L}$, respectively. The groundwater sample from this depth contained twice as much dissolved uranium, at $70.4 \mu \mathrm{g} / \mathrm{L}$. Similarly, the sediments collected from $47 \mathrm{ft}$ bgs had 1:1 sediment:water and UFA extractable uranium concentrations of 1.53 and $9.56 \mu \mathrm{g} / \mathrm{L}$, versus a concentration of $40.0 \mu \mathrm{g} / \mathrm{L}$ in the groundwater.

Perhaps more difficult to explain is the large amount of uranium in the 1:1 sediment:water and UFA extracts of sediments from approximately $74 \mathrm{ft} \mathrm{bgs}$ in comparison to the trace amount of uranium found in the groundwater. The pore water corrected water extract samples contained 74-75 $\mu \mathrm{g} / \mathrm{L}$ dissolved 
uranium while the UFA extracts contained 41 to $215 \mu \mathrm{g} / \mathrm{L}$. In comparison, the groundwater sample collected from $72.5 \mathrm{ft}$ bgs only contained $0.055 \mu \mathrm{g} / \mathrm{L}$ dissolved uranium. According to the information presented in Table 4.1, the Ringold Formation transitions from an undesignated finer-grained lithology to a coarse gravel unit at $73 \mathrm{ft}$ bgs in well 399-2-5. Perhaps the anomaly in dissolved uranium concentration is a result of misidentifying the exact depths (and subsequently lithology) from which either the sediment or groundwater samples were obtained. Certainly there are no anomalies with respect to the solution chemistry of the samples that can be used to explain this phenomenon. Additionally, there are no observable anomalies associated with the chemistry of the groundwater or lithology of these samples that can be used to explain this finding.

Table 5.18. Uranium Concentrations in Groundwater Samples from Well 399-2-5

\begin{tabular}{ccc}
\hline $\begin{array}{c}\text { Sample Name } \\
(\text { HEIS ID) }\end{array}$ & $\begin{array}{c}\text { Sample Mid Depth } \\
(\mathrm{ft} b g s)\end{array}$ & $\begin{array}{c}\text { Uranium-238 } \\
(\mu \mathrm{g} / \mathrm{L})\end{array}$ \\
\hline B1PL94 & 36.3 & $7.04 \mathrm{E}+01$ \\
B1PL95 & 48.0 & $4.00 \mathrm{E}+01$ \\
B1PL96 & 67.5 & $2.34 \mathrm{E}+00$ \\
B1PL98 & 72.5 & $5.50 \mathrm{E}-02$ \\
B1PL99 & 85.5 & $5.00 \mathrm{E}-02$ \\
B1PLB0 & 107.5 & $1.95 \mathrm{E}-01$ \\
B1PLB1 & 125.0 & $1.82 \mathrm{E}-01$ \\
\hline
\end{tabular}

\subsection{Sediment from Well 399-3-22 (Borehole C5706)}

\subsubsection{Moisture Content}

The moisture content of the 25 core liners and six moisture tins collected while drilling well 399-3-22 is listed as a function of depth in Table 5.19. The moisture content profile correlates with the lithology described in Section 4 and presented in Table 4.1. In general, the gravel-dominated sediment of the Hanford formation had low moisture content, with an average vadose zone moisture content of $7.52 \mathrm{wt} \%$. One sample collected within the Hanford formation vadose zone contained significantly more moisture, $31.9 \mathrm{wt} \%$, indicating that sediment collected from this depth contained more fine-grained material. Evaluation of this sample in the laboratory revealed that it contained large aggregates of fine-grained silty sediment. The remaining Hanford and Ringold Formation sediments were all collected below the water table (located at approximately $43 \mathrm{ft}$ bgs); therefore, their measured moisture contents reflect the ability of the sediments to retain pore water as they were brought to the surface in the core barrel. The measured moisture contents of the samples can be used to qualitatively identify the location (depth) of finer-grained material in this borehole. This qualitative assessment confirms the lithology described in Table 4.1 that indicates the Ringold Formation undesignated finer-grained interval began at approximately $64 \mathrm{ft}$ bgs at this location and extended to the terminus depth from which samples were analyzed ( $84 \mathrm{ft} \mathrm{bgs).}$ 
Table 5.19. Gravimetric Moisture Content of Samples Retrieved from Well 399-3-22

\begin{tabular}{lcc}
\hline $\begin{array}{c}\text { Sample Name } \\
\text { (HEIS ID) }\end{array}$ & $\begin{array}{c}\text { Sample Mid Depth } \\
\text { (ft bgs) }\end{array}$ & $\begin{array}{c}\text { Moisture Content } \\
(\mathrm{wt} \%)\end{array}$ \\
\hline B1PL33 & 9.5 & $2.07 \%$ \\
B1PL34 & 15.0 & $2.00 \%$ \\
B1PL35 & 20.0 & $4.46 \%$ \\
B1PL36 & 24.0 & $31.9 \%$ \\
B1PL37 & 30.0 & $4.63 \%$ \\
B1PL38 & 35.0 & $4.13 \%$ \\
B1PL55-4 & 37.3 & $7.95 \%$ \\
B1PL55-3 & 38.0 & $6.80 \%$ \\
B1PL55-2 & 38.7 & $5.67 \%$ \\
B1PL56-4 & 39.8 & $5.72 \%$ \\
B1PL56-3 & 40.5 & $9.35 \%$ \\
B1PL56-2 & 41.2 & $5.54 \%$ \\
B1PL57-4 & 42.9 & $18.8 \%$ \\
B1PL57-3 & 43.3 & $16.2 \%$ \\
B1PL57-2 & 43.6 & $21.0 \%$ \\
B1PL57-1 & 44.0 & $21.3 \%$ \\
B1PL58-4 & 59.0 & $10.2 \%$ \\
B1PL58-3 & 60.0 & $14.8 \%$ \\
B1PL58-2 & 61.0 & $4.23 \%$ \\
B1PL59-4 & 62.8 & $11.4 \%$ \\
B1PL59-3 & 63.4 & $8.75 \%$ \\
B1PL59-2 & 64.1 & $30.3 \%$ \\
B1PL59-1 & 64.7 & $36.0 \%$ \\
B1PL60-4 & 65.6 & $38.5 \%$ \\
B1PL60-3 & 66.2 & $35.3 \%$ \\
B1PL60-2 & 66.9 & $40.9 \%$ \\
B1PL60-1 & 67.5 & $40.2 \%$ \\
B1PL61-4 & 81.8 & $40.0 \%$ \\
B1PL61-3 & 82.4 & $36.6 \%$ \\
B1PL61-2 & 83.1 & $38.1 \%$ \\
B1PL61-1 & 83.7 & $34.4 \%$ \\
\hline & &
\end{tabular}

\subsubsection{1:1 Sediment:Water Extracts of Sediments from Well 399-3-22}

A subset of sediments from well 399-3-22 was characterized by performing 1:1 sediment:water extracts. The following tables present the mass of a given constituent leached per gram of sediment as measured in the water extracts. Other figures show dilution-corrected values that represent concentrations in vadose zone pore water. As mentioned previously, the assumption that none of the solid is dissolved during the water extraction process is simplistic. Further comparisons are made in later sections between calculated pore water concentrations and those directly extracted from the sediments using UFA.

\subsubsection{1 pH and Electrical Conductivity}

The $\mathrm{pH}$ and EC values of the water extracts of select samples from well 399-3-22 are listed in Table 5.20. Both geochemical parameters are tabulated as measured in the 1:1 sediment:water extracts. Additionally, the EC has been corrected back to a pore water concentration based on field-moist moisture content and is reported as pore water corrected in Table 5.20. The pH profile is constant with all values 
between 7.1 and 8.1 (within the typical range for Hanford sediments). The pore water-corrected EC data are equally constant, ranging from 0.501 to $3.75 \mathrm{mS} / \mathrm{cm}$ in the Hanford formation and 0.184 to $1.7 \mathrm{mS} / \mathrm{cm}$ in the Ringold Formation. The calculated pore water conductivities of samples collected from well 399-3-22 were quite dilute and compared well with pore water EC data measured in other 300 Area boreholes (Williams et al. 2007). Specifically, pore water conductivities ranged from 1.43 to $4.51 \mathrm{mS} / \mathrm{cm}$ in borehole C5001 and from 1.96 to 4.84 in borehole C5002.

Table 5.20. $\mathrm{pH}$ for 1:1 Sediment:Water Extracts and Dilution-Corrected EC Values from Well 399-3-22

\begin{tabular}{lcccc}
\hline $\begin{array}{c}\text { Sample Name } \\
\text { (HEIS ID) }\end{array}$ & $\begin{array}{c}\text { Sample Mid Depth } \\
\text { (ft bgs) }\end{array}$ & $\mathrm{pH}$ & $\begin{array}{c}\mathrm{EC} \\
(\mathrm{mS} / \mathrm{cm})\end{array}$ & $\begin{array}{c}\text { Pore Water Corrected } \\
\text { Conductivity (mS/cm) }\end{array}$ \\
\hline B1PL37 & 30.0 & 8.00 & $1.37 \mathrm{E}-01$ & $2.96 \mathrm{E}+00$ \\
B1PL38 & 35.0 & 7.98 & $1.55 \mathrm{E}-01$ & $3.75 \mathrm{E}+00$ \\
B1PL56-4 & 39.8 & 7.76 & $1.41 \mathrm{E}-01$ & $2.46 \mathrm{E}+00$ \\
B1PL56-3 & 40.5 & 8.09 & $2.53 \mathrm{E}-01$ & $2.71 \mathrm{E}+00$ \\
B1PL56-2 & 41.2 & 7.79 & $1.74 \mathrm{E}-01$ & $3.14 \mathrm{E}+00$ \\
B1PL56-2 DUP & 41.2 & 8.11 & $2.26 \mathrm{E}-01$ & $4.08 \mathrm{E}+00$ \\
B1PL57-4 & 42.9 & 7.94 & $2.96 \mathrm{E}-01$ & $1.57 \mathrm{E}+00$ \\
B1PL57-3 & 43.3 & 7.97 & $2.22 \mathrm{E}-01$ & $1.37 \mathrm{E}+00$ \\
B1PL57-2 & 43.6 & 7.13 & $1.05 \mathrm{E}-01$ & $5.01 \mathrm{E}-01$ \\
B1PL58-3 & 60.0 & 7.82 & $1.27 \mathrm{E}-01$ & $8.59 \mathrm{E}-01$ \\
B1PL58-2 & 61.0 & 7.57 & $7.60 \mathrm{E}-02$ & $1.80 \mathrm{E}+00$ \\
B1PL59-3 & 63.4 & 7.85 & $1.49 \mathrm{E}-01$ & $1.70 \mathrm{E}+00$ \\
B1PL60-1 & 67.5 & 7.14 & $7.40 \mathrm{E}-02$ & $1.84 \mathrm{E}-01$ \\
B1PL61-1 & 83.7 & 7.56 & $2.57 \mathrm{E}-01$ & $7.46 \mathrm{E}-01$ \\
B1PL61-1 DUP & 83.7 & 7.31 & $2.94 \mathrm{E}-01$ & $8.54 \mathrm{E}-01$ \\
\hline
\end{tabular}

\subsubsection{Composition of the 1:1 Sediment:Water Extracts from Well 399-3-22}

The concentrations of major anions, cations, and several trace constituents are discussed in this section. The anion data are tabulated in Table 5.21 in units of mass per gram of dry sediment. A comparison of the masses of water-extractable anions per gram of sediment from the Hanford and Ringold Formation units in well 399-3-22 showed that there were differences in the anion composition. The primary water-extractable anion in the Hanford formation was alkalinity (bicarbonate), while in the deeper Ringold Formation, the dominant water-extractable anion transitioned from alkalinity to sulfate. Unlike at well 399-2-5, the vadose zone in well 399-3-22 contains little nitrate (peak concentration of $4.97 \mu \mathrm{g} / \mathrm{g}$ ), indicating that it does not contain a significant fraction (if any) of contaminant nitrate.

The water-extractable major cations in sediments from well 399-3-22 are tabulated in Table 5.22 in units of mass per gram of sediment on a dry weight basis. The dominant water-extractable cations in the sediments from well 399-3-22 were calcium and sodium. Interestingly, considerably more sodium than calcium was present in the water extracts of the Hanford formation sediments collected above the water table. Specifically, the three samples collected within $42 \mathrm{ft}$ of ground surface contained 1.5 to 3.4 times more water-extractable sodium than calcium. Given the obvious signs of sodium contamination in these samples, it is a bit surprising that they did not have an apparent nitrate contamination signature because the two contaminants are typically synonymous with Hanford waste streams. Nitrate contamination should migrate deeper than a cation exchange front (which occurs as sodium or some other cation displaces the natural calcium and magnesium from the surface exchange sites on the sediment), which could explain the present situation, assuming the residual sodium is "trapped" in the vadose zone while the nitrate contamination has already entered the water table. Duplicate analyses of the deepest sediment 
analyzed from the Ringold Formation contained higher than expected concentrations of water-extractable potassium. At 9.27 and $10.4 \mu \mathrm{g} / \mathrm{g}$, there was 2.5 times more water-extractable potassium than magnesium in the samples analyzed from $83 \mathrm{ft}$ bgs in well 399-3-22. In comparison, the peak water-extractable potassium found in sediments collected within the Ringold Formation in borehole C5001 was $2.89 \mu \mathrm{g} / \mathrm{g}$, and all concentrations of water-extractable potassium were less than detectable in the Ringold Formation sediments analyzed from borehole C5002. It is unclear whether the elevated potassium in the Ringold Formation is a result of contamination or if its presence can be explained due to sediment mineralogy (potentially K-feldspar in the sediments).

Table 5.21. Water-Extractable Anions in Sediments from Well 399-3-22 ( $\mu \mathrm{g} / \mathrm{g}$ dry sediment $)^{(\mathrm{a})}$

\begin{tabular}{|c|c|c|c|c|c|c|c|}
\hline $\begin{array}{l}\text { Sample Name } \\
\text { (HEIS ID) }\end{array}$ & $\begin{array}{c}\text { Sample } \\
\text { Mid Depth } \\
\text { (ft bgs) }\end{array}$ & $\begin{array}{c}\text { Fluoride } \\
(\mu \mathrm{g} / \mathrm{g})\end{array}$ & $\begin{array}{c}\text { Chloride } \\
(\mu \mathrm{g} / \mathrm{g})\end{array}$ & $\begin{array}{l}\text { Nitrate } \\
(\mu \mathrm{g} / \mathrm{g})\end{array}$ & $\begin{array}{l}\text { Sulfate } \\
(\mu \mathrm{g} / \mathrm{g})\end{array}$ & $\begin{array}{c}\text { Phosphate } \\
(\mu \mathrm{g} / \mathrm{g})\end{array}$ & $\begin{array}{c}\text { Alkalinity } \\
\text { as } \mathrm{CaCO}_{3} \\
(\mu \mathrm{g} / \mathrm{g}) \\
\end{array}$ \\
\hline B1PL37 & 30.0 & $6.43 \mathrm{E}-01$ & $1.05 \mathrm{E}+00$ & $<1.01 \mathrm{E}+00$ & $4.48 \mathrm{E}+00$ & $<1.51 \mathrm{E}+00$ & $6.23 \mathrm{E}+01$ \\
\hline B1PL38 & 35.0 & $8.02 \mathrm{E}-01$ & $1.19 \mathrm{E}+00$ & $<1.00 \mathrm{E}+00$ & $6.86 \mathrm{E}+00$ & $<1.50 \mathrm{E}+00$ & $6.54 \mathrm{E}+01$ \\
\hline B1PL56-2 & 41.2 & $7.58 \mathrm{E}-01$ & $2.15 \mathrm{E}+00$ & $<1.00 \mathrm{E}+00$ & $1.61 \mathrm{E}+01$ & $<1.51 \mathrm{E}+00$ & $6.23 \mathrm{E}+01$ \\
\hline B1PL57-2 & 43.6 & $7.20 \mathrm{E}-01$ & $4.49 \mathrm{E}+00$ & $4.97 \mathrm{E}+00$ & $1.61 \mathrm{E}+01$ & $<1.50 \mathrm{E}+00$ & $1.98 \mathrm{E}+01$ \\
\hline B1PL58-2 & 61.0 & $3.13 \mathrm{E}-01$ & $1.40 \mathrm{E}+00$ & $<1.00 \mathrm{E}+00$ & $5.85 \mathrm{E}+00$ & $<1.50 \mathrm{E}+00$ & $3.57 \mathrm{E}+01$ \\
\hline B1PL59-3 & 63.4 & $5.29 \mathrm{E}-01$ & $2.46 \mathrm{E}+00$ & $<1.01 \mathrm{E}+00$ & $2.27 \mathrm{E}+01$ & $<1.51 \mathrm{E}+00$ & $4.94 \mathrm{E}+01$ \\
\hline B1PL60-1 & 67.5 & $2.70 \mathrm{E}-01$ & $2.40 \mathrm{E}+00$ & $3.50 \mathrm{E}+00$ & $9.54 \mathrm{E}+00$ & $<1.50 \mathrm{E}+00$ & $2.36 \mathrm{E}+01$ \\
\hline B1PL61-1 & 83.7 & $2.45 \mathrm{E}-01$ & $1.07 \mathrm{E}+00$ & $<1.00 \mathrm{E}+00$ & $7.81 \mathrm{E}+01$ & $<1.50 \mathrm{E}+00$ & $2.43 \mathrm{E}+01$ \\
\hline B1PL61-1 DUP & 83.7 & $2.65 \mathrm{E}-01$ & $1.42 \mathrm{E}+00$ & $1.38 \mathrm{E}+00$ & $9.59 \mathrm{E}+01$ & $<1.50 \mathrm{E}+00$ & $2.96 \mathrm{E}+01$ \\
\hline
\end{tabular}

Table 5.22. Water-Extractable Major Cations in Sediments from Well 399-3-22 ( $\mu \mathrm{g} / \mathrm{g}$ dry sediment)

\begin{tabular}{lcccccc}
\hline $\begin{array}{c}\text { Sample Name } \\
(\text { HEIS ID) }\end{array}$ & $\begin{array}{c}\text { Sample Mid } \\
\text { Depth }(\mathrm{ft} \mathrm{bgs})\end{array}$ & $\begin{array}{c}\text { Calcium } \\
(\mu \mathrm{g} / \mathrm{g})\end{array}$ & $\begin{array}{c}\text { Potassium } \\
(\mu \mathrm{g} / \mathrm{g})\end{array}$ & $\begin{array}{c}\text { Magnesium } \\
(\mu \mathrm{g} / \mathrm{g})\end{array}$ & $\begin{array}{c}\text { Strontium( } \mu \\
\mathrm{g} / \mathrm{g})\end{array}$ & $\begin{array}{c}\text { Sodium } \\
(\mu \mathrm{g} / \mathrm{g})\end{array}$ \\
\hline B1PL37 & 30.0 & $5.72 \mathrm{E}+00$ & $<3.78 \mathrm{E}+00$ & $9.91 \mathrm{E}-01$ & $2.82 \mathrm{E}-02$ & $1.95 \mathrm{E}+01$ \\
B1PL38 & 35.0 & $6.62 \mathrm{E}+00$ & $<3.76 \mathrm{E}+00$ & $1.20 \mathrm{E}+00$ & $3.08 \mathrm{E}-02$ & $2.15 \mathrm{E}+01$ \\
B1PL56-2 & 41.2 & $1.10 \mathrm{E}+01$ & $<3.77 \mathrm{E}+00$ & $2.10 \mathrm{E}+00$ & $5.39 \mathrm{E}-02$ & $1.74 \mathrm{E}+01$ \\
B1PL57-2 & 43.6 & $5.83 \mathrm{E}+00$ & $<3.75 \mathrm{E}+00$ & $1.29 \mathrm{E}+00$ & $2.89 \mathrm{E}-02$ & $8.45 \mathrm{E}+00$ \\
B1PL58-2 & 61.0 & $5.27 \mathrm{E}+00$ & $<3.75 \mathrm{E}+00$ & $1.11 \mathrm{E}+00$ & $2.33 \mathrm{E}-02$ & $5.38 \mathrm{E}+00$ \\
B1PL59-3 & 63.4 & $1.12 \mathrm{E}+01$ & $<3.78 \mathrm{E}+00$ & $2.49 \mathrm{E}+00$ & $5.31 \mathrm{E}-02$ & $9.57 \mathrm{E}+00$ \\
B1PL60-1 & 67.5 & $5.08 \mathrm{E}+00$ & $<3.76 \mathrm{E}+00$ & $1.16 \mathrm{E}+00$ & $2.55 \mathrm{E}-02$ & $4.31 \mathrm{E}+00$ \\
B1PL61-1 & 83.7 & $2.16 \mathrm{E}+01$ & $9.27 \mathrm{E}+00$ & $3.40 \mathrm{E}+00$ & $1.18 \mathrm{E}-01$ & $1.36 \mathrm{E}+01$ \\
B1PL61-1 DUP & 83.7 & $2.58 \mathrm{E}+01$ & $1.04 \mathrm{E}+01$ & $4.05 \mathrm{E}+00$ & $1.41 \mathrm{E}-01$ & $1.56 \mathrm{E}+01$ \\
\hline
\end{tabular}

The water-extractable aluminum, iron, sulfur, and phosphorus in sediments from well 399-3-22 are shown in Table 5.23. The sulfur and phosphorus data were converted to water-extractable sulfur as sulfate and phosphorus as phosphate so that the results could be compared to the IC data presented in Table 5.21. The agreement between directly measured sulfate in the water extracts using IC and indirectly by converting the ICP measurements for sulfur to sulfate was mixed. Percent differences between the two data sets ranged from 3.5 to $32 \%$. Of the eight samples analyzed, only four had percent differences of less than $10 \%$. These samples were the ones collected within the middle of the borehole (from the top of the aquifer extending to a depth of $68 \mathrm{ft} \mathrm{bgs}$ ). The depth range covered by these four samples covers both the Hanford and Ringold formations. Duplicate analysis of the deepest sample collected (B1PL61-1) resulted in an average difference of 30\%. This sample was also collected within the Ringold Formation unit of upper unconfined aquifer; therefore, the discrepancy between ICP and IC 
measured sulfur/sulfate cannot be associated with a single stratigraphic unit or be attributed solely to a vadose zone or aquifer effect. In all cases, the ICP-converted sulfur number was always greater than the IC-measured sulfate number. This could indicate that there is a non-sulfate source of sulfur in these sediments or that there is a spectral interference in the ICP data at the wavelength used to quantify sulfur; although given the low ionic strength of the water extract, most spectral interferences should be insignificant. The IC analytical technique was unable to detect phosphate in the water extract samples above the instrument's limit of quantification; therefore, a direct comparison of the two techniques could not be performed. Water-extractable phosphorus was quantitatively measured in the three shallowest samples analyzed from well 399-3-22. The reported concentrations were either at or below the detection limits reported for phosphate via IC; therefore, using the ICP data to determine the phosphate concentration in the sediments seems reasonable (i.e., it is doubtful there is a non-phosphate source of phosphorus in these samples). The small amounts of water-soluble iron and aluminum that were detected intermittently in some of the samples analyzed from well 399-3-22 likely came from natural iron and aluminum bearing minerals present in the sediments.

Table 5.23. Water-Extractable Cations in Sediments from Well 399-3-22 ( $\mu \mathrm{g} / \mathrm{g}$ dry sediment $)^{(\mathrm{a})}$

\begin{tabular}{lccccc}
\hline $\begin{array}{c}\text { Sample Name } \\
(\text { HEIS ID) }\end{array}$ & $\begin{array}{c}\text { Sample Mid } \\
\text { Depth } \\
(\mathrm{ft} \text { bgs })\end{array}$ & $\begin{array}{c}\text { Aluminum } \\
(\mu \mathrm{g} / \mathrm{g})\end{array}$ & $\begin{array}{c}\text { Sulfur } \\
\text { Iron }(\mu \mathrm{g} / \mathrm{g})\end{array}$ & $\begin{array}{c}\mathrm{SO}_{4}{ }^{2-} \\
(\mu \mathrm{g} / \mathrm{g})\end{array}$ & $\begin{array}{c}\text { Phosphorus as } \\
\mathrm{PO}_{4}{ }^{3-}(\mu \mathrm{g} / \mathrm{g})\end{array}$ \\
\hline B1PL37 & 30.0 & $4.61 \mathrm{E}-02$ & $4.84 \mathrm{E}-02$ & $5.54 \mathrm{E}+00$ & $1.61 \mathrm{E}+00$ \\
B1PL38 & 35.0 & $3.71 \mathrm{E}-02$ & $3.32 \mathrm{E}-02$ & $9.52 \mathrm{E}+00$ & $9.59 \mathrm{E}-01$ \\
B1PL56-2 & 41.2 & $3.38 \mathrm{E}-02$ & $<3.01 \mathrm{E}-02$ & $1.96 \mathrm{E}+01$ & $1.33 \mathrm{E}+00$ \\
B1PL57-2 & 43.6 & $<3.00 \mathrm{E}-02$ & $<3.00 \mathrm{E}-02$ & $1.68 \mathrm{E}+01$ & $<5.76 \mathrm{E}-01$ \\
B1PL58-2 & 61.0 & $7.00 \mathrm{E}-02$ & $9.51 \mathrm{E}-02$ & $6.31 \mathrm{E}+00$ & $<5.75 \mathrm{E}-01$ \\
B1PL59-3 & 63.4 & $5.19 \mathrm{E}-02$ & $<3.02 \mathrm{E}-02$ & $2.35 \mathrm{E}+01$ & $<5.79 \mathrm{E}-01$ \\
B1PL60-1 & 67.5 & $<3.00 \mathrm{E}-02$ & $4.77 \mathrm{E}-02$ & $1.02 \mathrm{E}+01$ & $<5.76 \mathrm{E}-01$ \\
B1PL61-1 & 83.7 & $<3.00 \mathrm{E}-02$ & $<3.00 \mathrm{E}-02$ & $1.08 \mathrm{E}+02$ & $<5.75 \mathrm{E}-01$ \\
B1PL61-1 DUP & 83.7 & $7.74 \mathrm{E}-02$ & $5.85 \mathrm{E}-02$ & $1.27 \mathrm{E}+02$ & $<5.77 \mathrm{E}-01$ \\
\hline (a) < symbol indicates the analyte was below the detection limit. The minimum detection limit has been reported.
\end{tabular}

The water extract data for uranium-238 are shown in Table 5.24; results are tabulated as a function of dry sediment weight in units of mass $(\mu \mathrm{g} / \mathrm{g})$. Although less emphasis was placed on the samples from well 399-3-22 than those from well 399-2-5, several more samples were processed to determine their water-leachable uranium concentrations than for general inorganic constituents. All but one of the samples (represented by $<$ symbol in Table 5.24) analyzed contained quantifiable concentrations of waterextractable uranium-238. Uranium is a naturally-occurring element and, as such, is generally quantifiable in water extracts of any sediment analyzed (dashed vertical line in Figure 5.5). In addition to natural uranium, several samples retrieved within the vadose zone just above the water table contained quantifiable concentrations of contaminant uranium. While contaminant uranium is clearly present in sediments from this borehole, the peak water-extractable concentration of $2.33 \mathrm{E}-02 \mu \mathrm{g} / \mathrm{g}$ is still quite dilute. However, the peak water-extractable uranium concentration measured in vadose zone sediments from well 399-3-22 was greater than that measured in vadose zone sediments from well 399-2-5 (2.06E$02 \mu \mathrm{g} / \mathrm{g}$ ). This is surprising because well 399-3-22 is far from any known waste disposal point, while well 399-2-5 was drilled within the footprint of the SPP. Like well 399-2-5, the peak uranium-238 contaminated sediments found in well 399-3-22 were collected just above the water table within the capillary fringe. These data imply that within the 300 Area there is a rather dilute but extensive source of contaminant uranium in the lower vadose zone and capillary fringe. 
Table 5.24. Water-Extractable Uranium in Sediments from Well 399-3-22 (a)

\begin{tabular}{lcc}
\hline $\begin{array}{c}\text { Sample Name } \\
(\text { HEIS ID) }\end{array}$ & $\begin{array}{c}\text { Sample Mid Depth } \\
(\mathrm{ft} \text { bgs })\end{array}$ & $\begin{array}{c}\text { Uranium-238 } \\
(\mu \mathrm{g} / \mathrm{g})\end{array}$ \\
\hline B1PL37 & 30.0 & $1.10 \mathrm{E}-03$ \\
B1PL38 & 35.0 & $1.21 \mathrm{E}-03$ \\
B1PL56-4 & 39.8 & $1.92 \mathrm{E}-03$ \\
B1PL56-3 & 40.5 & $1.77 \mathrm{E}-02$ \\
B1PL56-2 & 41.2 & $1.10 \mathrm{E}-02$ \\
B1PL56-2 DUP & 41.2 & $1.29 \mathrm{E}-02$ \\
B1PL57-4 & 42.9 & $2.33 \mathrm{E}-02$ \\
B1PL57-3 & 43.3 & $7.19 \mathrm{E}-03$ \\
B1PL57-2 & 43.6 & $2.05 \mathrm{E}-04$ \\
B1PL58-3 & 60.0 & $1.83 \mathrm{E}-03$ \\
B1PL58-2 & 61.0 & $7.89 \mathrm{E}-04$ \\
B1PL59-3 & 63.4 & $2.08 \mathrm{E}-03$ \\
B1PL60-1 & 67.5 & $<1.00 \mathrm{E}-04$ \\
B1PL61-1 & 83.7 & $2.64 \mathrm{E}-03$ \\
B1PL61-1 DUP & 83.7 & $2.43 \mathrm{E}-03$ \\
\hline (a) < symbol indicates the analyte was below the detection limit. & The minimum \\
detection limit has been reported. & \\
\hline
\end{tabular}

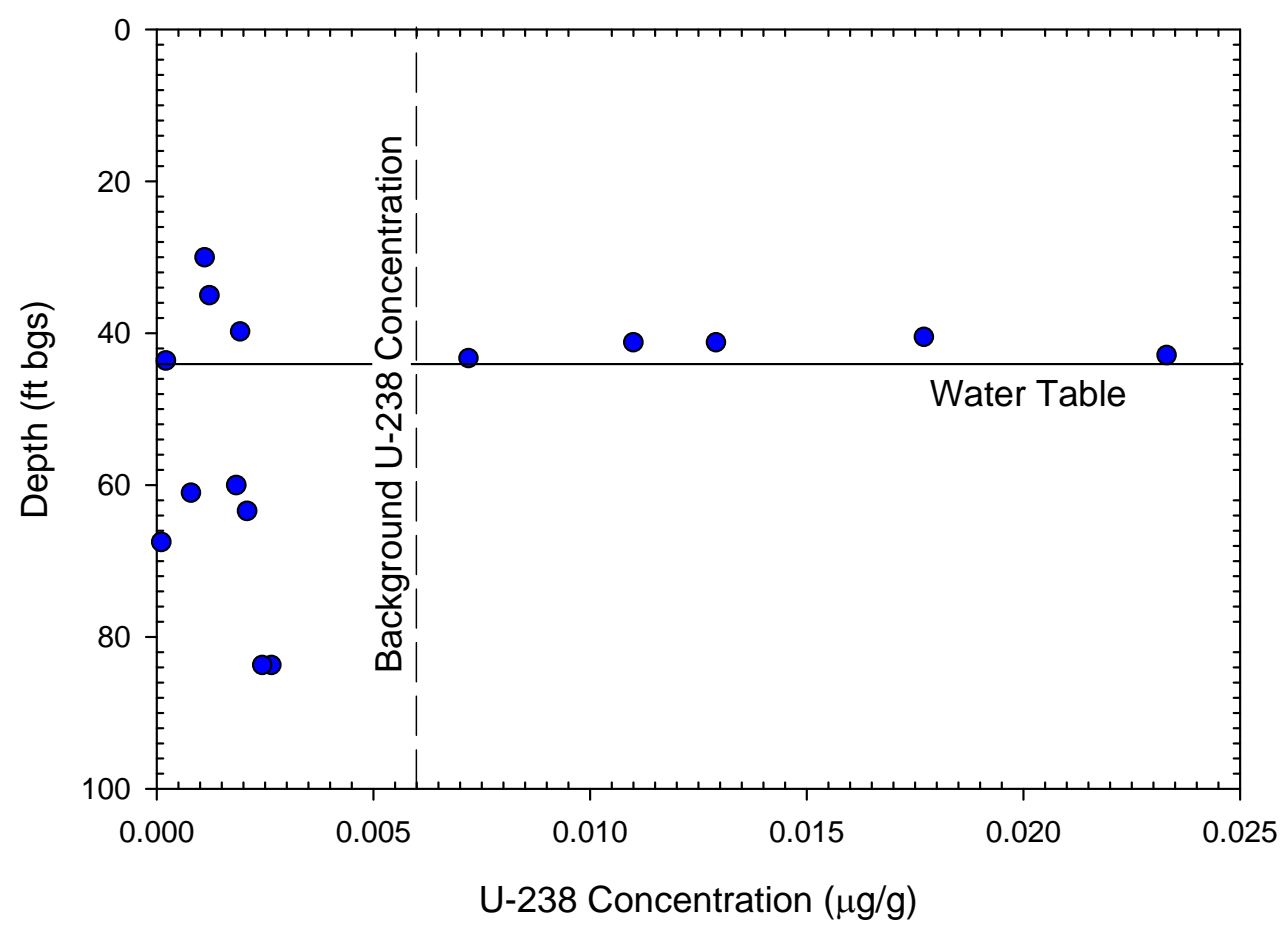

Figure 5.5. Concentration of Water-Extractable Uranium-238 in Sediments from Well 399-3-22

\subsubsection{Pore Water Chemical Composition}

The chemical composition of the residual pore water in sediments from well 399-3-22 can be ascertained in two ways. The first method uses the 1:1 sediment:water extract results presented in Section 5.2.2 and the measured moisture content of the field-moist sediments (Section 5.2.1). Using this approach, the concentrations of the respective analytes measured in the 1:1 sediment:water extracts are 
assumed to be wholly present in the residual pore water. Although these samples were air-dried prior to extraction, it is reasonable to assume that the 1:1 sediment:water extract would have efficiently dissolved the constituents that precipitated upon drying of the samples. Thus, by attributing the concentrations of dissolved species in the extracts to the field moist residual pore water, an estimate of the actual chemical composition of the native pore water in the vadose zone sediments can be derived. The second method is much more direct, involving extraction of the residual pore water using UFA. The extracted pore water can then be analyzed directly without further dilution.

\subsubsection{Pore Water pH and Electrical Conductivity}

Table 5.25 contains the $\mathrm{pH}$ and EC data for UFA extracts of sediments from well 399-3-22. The range in measured $\mathrm{pH}$ values for the UFA extracts is similar but slightly higher than those measured using the 1:1 sediment:water extraction technique, with a range of 7.25 to 8.38 . Hanford sediments generally contain sufficient concentrations of carbonate-bearing minerals to generate groundwater and pore water solutions in the $\mathrm{pH}$ range between 7.0 and 8.5. Therefore, the $\mathrm{pH}$ data generated using both techniques are consistent with prior results and expectations.

Comparison of the EC data present in Table 5.25 with those generated using 1:1 sediment:water extracts (Table 5.20) yields mixed results. In most cases, the UFA extract EC data fall between the asmeasured values in the 1:1 sediment:water extracts and the pore water-corrected values. In every case except one, sample B1PL61-1, the UFA extract EC result was 30\% or more lower than the pore water corrected value, and in most cases, the numbers differed by at least a factor of 2. For sample B1PL61-1, the two techniques (UFA extraction versus pore water-corrected water extract data) agreed well (relative difference of $4.3 \%$ ). For the remaining samples, the average difference between the two techniques was $96 \%$, and the UFA extracts results were always lower than the pore water-corrected water extract data. This implies that the process of drying the samples and then extracting them using the 1:1 sediment:water technique has resulted in at least partial dissolution of the sediment.

Table 5.25. $\mathrm{pH}$ and EC Data in UFA Extracts of Sediments from Well 399-3-22

\begin{tabular}{cccc}
\hline $\begin{array}{c}\text { Sample Name } \\
\text { (HEIS ID) }\end{array}$ & $\begin{array}{c}\text { Sample Mid Depth } \\
\text { (ft bgs) }\end{array}$ & $\mathrm{pH}$ & $\begin{array}{c}\text { Electrical Conductivity } \\
(\mathrm{mS} / \mathrm{cm})\end{array}$ \\
\hline B1PL56-4 UFA & 39.8 & 7.76 & $6.21 \mathrm{E}-01$ \\
B1PL56-3 UFA & 40.5 & 8.09 & $6.38 \mathrm{E}-01$ \\
B1PL56-2 UFA & 41.2 & 8.38 & $7.17 \mathrm{E}-01$ \\
B1PL57-4 UFA & 42.9 & 7.55 & $6.99 \mathrm{E}-01$ \\
B1PL57-3 UFA & 43.3 & 7.63 & $3.97 \mathrm{E}-01$ \\
B1PL57-2 UFA & 43.6 & 7.63 & $3.12 \mathrm{E}-01$ \\
B1PL58-3 UFA & 60.0 & 7.70 & $4.32 \mathrm{E}-01$ \\
B1PL61-1 UFA & 83.7 & 7.25 & $8.35 \mathrm{E}-01$ \\
\hline
\end{tabular}

\subsubsection{Major Anions and Cations}

Table 5.26 contains the major anions and Table 5.27 contains the major cations in UFA extracts as well as the corresponding pore water-corrected 1:1 sediment:water extract data for sediments from well 399-3-22 All of the data have been converted to units of meq/L so that charge-balance comparisons (anions versus cations) could be made. Only two samples from well 399-3-22 contain complementary UFA and pore water-corrected sediment:water extract data: B1PL57-2 and B1PL61-1. Comparison of 
the two sets of anion data reported in Table 5.27 reveals mixed results. One of the samples analyzed had a greater concentration of water-extractable anions (B1PL57-2), while the other sample had a greater concentration of UFA-extractable anions (B1PL61-1). Specifically, sample B1PL57-2 contained 31\% more anions in the pore water corrected extract versus the UFA extract. Conversely, sample B1PL61-1 contained $48 \%$ more anions in the UFA extract than the pore water-corrected water extract. The dominant dissolved anion in sample B1PL57-2 was alkalinity, while sulfate was the dominant anion in extracts of sample B1PL61-1. Evaluation of each specific anion in the two extracts indicated that is was these two dominant anions, sulfate and bicarbonate, that had the greatest variability between the two types of extracts. For example, bicarbonate varied by approximately 15 and $40 \%$ in the UFA and water extracts of samples B1PL61-1 and B1PL57-2, respectively, while sulfate varied by 72 and 34\%. In cases where the dissolved constituents vary between 1:1 sediment:water extracts and UFA extracts, it is difficult to definitively identify the cause, particularly when such a small sample set was available. Given that the two dominant extractable anions were the elements most affected, sample heterogeneity seems to be the most likely cause of the discrepancy.

Table 5.26. Major Anions in UFA Extracts and Pore Water-Corrected 1:1 Sediment:Water Extracts of Sediments from Well 399-3-22(a)

\begin{tabular}{cccccccc}
\hline $\begin{array}{c}\text { Sample Name } \\
\text { (HEIS ID) }\end{array}$ & $\begin{array}{c}\text { Sample } \\
\text { Mid Depth } \\
\text { (ft bgs) }\end{array}$ & $\begin{array}{c}\text { Fluoride } \\
(\mathrm{meq} / \mathrm{L})\end{array}$ & $\begin{array}{c}\text { Chloride } \\
(\mathrm{meq} / \mathrm{L})\end{array}$ & $\begin{array}{c}\text { Nitrate } \\
(\mathrm{meq} / \mathrm{L})\end{array}$ & $\begin{array}{c}\text { Sulfate } \\
(\mathrm{meq} / \mathrm{L})\end{array}$ & $\begin{array}{c}\text { Phosphate } \\
\text { (meq/L) }\end{array}$ & $\begin{array}{c}\text { Alkalinity } \\
\text { as CO }{ }^{2-} \\
(\mathrm{meq} / \mathrm{L})\end{array}$ \\
\hline Bore Water Corrected Water Extract Data \\
\hline B1PL57-2 & 43.6 & $1.81 \mathrm{E}-01$ & $6.03 \mathrm{E}-01$ & $3.76 \mathrm{E}-01$ & $1.59 \mathrm{E}+00$ & $<2.26 \mathrm{E}-01$ & $1.89 \mathrm{E}+00$ \\
B1PL61-1 & 83.7 & $3.74 \mathrm{E}-02$ & $8.76 \mathrm{E}-02$ & $4.61 \mathrm{E}-02$ & $4.72 \mathrm{E}+00$ & $<1.38 \mathrm{E}-01$ & $1.41 \mathrm{E}+00$ \\
B1PL61-1 DUP & 83.7 & $4.05 \mathrm{E}-02$ & $1.16 \mathrm{E}-01$ & $6.35 \mathrm{E}-02$ & $5.78 \mathrm{E}+00$ & $<1.38 \mathrm{E}-01$ & $1.72 \mathrm{E}+00$ \\
\hline & \multicolumn{7}{c}{ UFA Extract Data } \\
\hline B1PL57-2 UFA & 43.6 & $<1.05 \mathrm{E}-01$ & $6.44 \mathrm{E}-01$ & $3.86 \mathrm{E}-01$ & $1.13 \mathrm{E}+00$ & $<4.74 \mathrm{E}-01$ & $1.22 \mathrm{E}+00$ \\
B1PL61-1 UFA & 83.7 & $<1.05 \mathrm{E}-01$ & $(1.35 \mathrm{E}-01)$ & $<1.61 \mathrm{E}-01$ & $1.00 \mathrm{E}+01$ & $<4.74 \mathrm{E}-01$ & $1.22 \mathrm{E}+00$ \\
\hline
\end{tabular}

(a) $<$ symbol indicates the analyte was below the detection limit. The minimum detection limit has been reported.

The 1:1 sediment:water and UFA-extractable cation data in Table 5.27 exhibit trends that are nearly identical to the anion results in Table 5.26. Specifically, sample B1PL57-2 contained 24\% more cations in the pore water-corrected extract than in the UFA extract. Conversely, sample B1PL61-1 contained $57 \%$ more cations in the UFA extract than the pore water-corrected water extract. The dominant dissolved cation in both UFA extracts was calcium, followed by sodium, magnesium, potassium, and strontium. In the 1:1 sediment:water extract samples, sodium was the dominant extractable cation in the Hanford formation sample, while calcium was the dominant water-extractable cation in the Ringold Formation sample. Similar to the anion data, evaluation of each specific cation in the two extracts did not yield a consistent trend. For example, for the Hanford formation sample (B1PL57-2), the only cation exhibiting poor agreement between the water and UFA extracts was sodium, and the relative percent difference between the two extracts was $66 \%$. Conversely, for the sample retrieved within the Ringold Formation, the only cation exhibiting poor agreement between the water and UFA extracts was calcium, and the relative percent difference between the two extracts was $71 \%$. The large variability between water-extractable calcium in these two extracts was not observed in sediments from well 399-2-5. However, with only one data point, it is not possible to determine whether the result is due to sample heterogeneity or something associated with one of the extraction techniques. 
Table 5.27. Major Cations in UFA Extracts and Pore Water-Corrected 1:1 Sediment:Water Extracts of Sediments from Well 399-3-22

\begin{tabular}{lcccccc}
\hline $\begin{array}{c}\text { Sample Name } \\
\text { (HEIS ID) }\end{array}$ & $\begin{array}{c}\text { Sample } \\
\text { Mid Depth } \\
\text { (ft bgs) }\end{array}$ & $\begin{array}{c}\text { Calcium } \\
\text { (meq/L) }\end{array}$ & $\begin{array}{c}\text { Potassium } \\
\text { (meq/L) }\end{array}$ & $\begin{array}{c}\text { Magnesium } \\
\text { (meq/L) }\end{array}$ & $\begin{array}{c}\text { Strontium } \\
\text { (meq/L) }\end{array}$ & $\begin{array}{c}\text { Sodium } \\
\text { (meq/L) }\end{array}$ \\
\hline B1PL57-2 & 43.6 & $1.39 \mathrm{E}+00$ & $<4.59 \mathrm{E}-01$ & $5.06 \mathrm{E}-01$ & $3.14 \mathrm{E}-03$ & $1.75 \mathrm{E}+00$ \\
B1PL61-1 & 83.7 & $3.14 \mathrm{E}+00$ & $<6.90 \mathrm{E}-01$ & $8.13 \mathrm{E}-01$ & $7.81 \mathrm{E}-03$ & $1.72 \mathrm{E}+00$ \\
B1PL61-1 DUP & 83.7 & $3.72 \mathrm{E}+00$ & $<7.75 \mathrm{E}-01$ & $9.66 \mathrm{E}-01$ & $9.32 \mathrm{E}-03$ & $1.96 \mathrm{E}+00$ \\
\hline \multicolumn{7}{c}{ UFA Extract Data } \\
\hline B1PL57-2 UFA & 43.6 & $1.38 \mathrm{E}+00$ & $1.33 \mathrm{E}-01$ & $4.72 \mathrm{E}-01$ & $3.16 \mathrm{E}-03$ & $8.84 \mathrm{E}-01$ \\
B1PL61-1 UFA & 83.7 & $7.20 \mathrm{E}+00$ & $5.46 \mathrm{E}-01$ & $1.52 \mathrm{E}+00$ & $1.76 \mathrm{E}-02$ & $1.79 \mathrm{E}+00$ \\
\hline
\end{tabular}

(a) $<$ symbol indicates the analyte was below the detection limit. The minimum detection limit has been reported.

A review of the charge balance between anions and cations in the water and UFA extracts of samples from well 399-3-22 indicated that similar to samples from well 399-2-5, the samples were slightly overcharged with respect to anions. The percent difference in charge balance ranged from 2.9 to $24 \%$, with an average difference of $14 \%$. In every case, the total charge associated with the anions exceeded that of the cations. There was no remarkable difference between the water and UFA extract samples; results from UFA extracts were out of balance by 2.9 to $16 \%$, while the differences ranged from 10 to $24 \%$ for the water extract samples. Given this, the difference in total charge between anions and cations cannot be attributed to dissolution of host sediment during the 1:1 sediment:water extract; instead, the differences may either be due to an effect occurring during sample storage or an analytical bias when the sediment extracts are analyzed in the laboratory.

Table 5.28 contains uranium-238 data from both the 1:1 sediment:water and UFA extracts. As the primary constituent of concern for this study, more data are available for comparing uranium-238 concentrations in the two extracts than any other constituent. Based on the major anion and cation data presented in Tables 5.26 and 5.27, the 1:1 sediment:water extracts almost always had higher dissolved salt loads than the UFA extracts. Conversely, for the eight samples for which comparative data exists, all but two of the samples had higher uranium-238 concentrations in the UFA extracts than in the water extracts. Further, of the six samples with higher UFA-extractable uranium-238, four had percent differences of approximately $75 \%$ or greater. Sample B1PL57-4 was the only sample to have a consistent water and UFA-extractable uranium-238 concentration, with a difference of $11 \%$ between the two extracts. Samples B1PL56-2 and B1PL56-3 contained 59 and 82\% more uranium in the water than UFA extracts, respectively.

While large discrepancies were observed between the water and UFA extracts throughout the entire sediment profile, the agreement was in general poorer for sediments retrieved from the saturated zone. Within the saturated zone, the phenomenon does not appear to be stratigraphically related because samples collected within the Hanford and Ringold formations both had statistically significant differences between water and UFA extractable uranium-238. Based on these data (as with the sediments analyzed from well 399-2-5), it appears that a process could be leading to the sequestration of uranium during the storage of sediment samples or potentially during the 1:1 sediment:water extract process. Uranium is a redox-sensitive element, and as such, it could be subject to reduction (converting it to a less soluble form) during storage given an appropriate reducing agent. A possible reducing agent in these samples could be ferrous iron. Ferrous iron is often released as iron containing rocks, such as basalt, are ground up during the drilling process. Another possibility is that the higher uranium concentration found in UFA sample 
could be attributed to more uranium residing in micropores of fine-grained sediments. Since the UFA uses ultracentrifugation to extract pore water from the sediments, more dissolved uranium present in either dead pore volumes or isolated pores can be extracted by this artificially enhanced suction, which can result in higher uranium concentration in the UFA extracts compared to those in 1:1 water extracts. Another artifact that cannot be reconciled is that the higher alkalinity concentrations measured in the water extracts should have led to higher overall uranium concentrations, as the carbonate would complex with the uranium, increasing its solubility. While the root cause remains unknown at this time, it is clear that measurable differences in extractable uranium exist in the 1:1 sediment:water versus UFA extracts, which is discouraging.

Table 5.28. Uranium Concentrations in UFA Extracts and Pore Water-Corrected 1:1 Sediment:Water Extracts of Sediments from Well 399-3-22

\begin{tabular}{lcc}
\hline $\begin{array}{c}\text { Sample Name } \\
(\text { HEIS ID) }\end{array}$ & $\begin{array}{c}\text { Sample Mid Depth } \\
(\mathrm{ft} \text { bgs })\end{array}$ & $\begin{array}{c}\text { Uranium-238 } \\
(\mu \mathrm{g} / \mathrm{L})\end{array}$ \\
\hline \multicolumn{1}{c}{ Pore Water Corrected Water Extract } & Data \\
\hline B1PL56-4 & 39.8 & $3.35 \mathrm{E}+01$ \\
B1PL56-3 & 40.5 & $1.89 \mathrm{E}+02$ \\
B1PL56-2 & 41.2 & $1.98 \mathrm{E}+02$ \\
B1PL56-2 DUP & 41.2 & $2.33 \mathrm{E}+02$ \\
B1PL57-4 & 42.9 & $1.24 \mathrm{E}+02$ \\
B1PL57-3 & 43.3 & $4.43 \mathrm{E}+01$ \\
B1PL57-2 & 43.6 & $9.78 \mathrm{E}-01$ \\
B1PL58-3 & 60.0 & $1.24 \mathrm{E}+01$ \\
B1PL61-1 & 83.7 & $7.65 \mathrm{E}+00$ \\
B1PL61-1 DUP & 83.7 & $7.05 \mathrm{E}+00$ \\
\hline \multicolumn{3}{c}{} \\
\hline B1PL56-4 UFA & UFA Extract Data \\
B1PL56-3 UFA & 39.8 & $4.57 \mathrm{E}+01$ \\
B1PL56-2 UFA & 40.5 & $7.88 \mathrm{E}+01$ \\
B1PL57-4 UFA & 41.2 & $1.17 \mathrm{E}+02$ \\
B1PL57-3 UFA & 42.9 & $1.39 \mathrm{E}+02$ \\
B1PL57-2 UFA & 43.3 & $1.98 \mathrm{E}+02$ \\
B1PL58-3 UFA & 43.6 & $2.22 \mathrm{E}+00$ \\
B1PL61-1 UFA & 60.0 & $1.59 \mathrm{E}+02$ \\
\hline
\end{tabular}

\subsection{4 $8 \mathrm{M}$ Nitric Acid-Extractable and Microwave-Assisted Digestible Concentrations of Uranium-238 in Sediments from Well 399-3-22}

Several samples from well 399-3-22 contained elevated concentrations of water-extractable uranium (which has been attributed to contaminant uranium); therefore, a comparison of extraction techniques was performed to investigate the total concentration of uranium-238 in these samples. It is acknowledged that solely measuring uranium-238 does not take into account the other uranium isotopes present in these samples; however, the total mass concentrations of uranium-235, uranium-234 (and possibly uranium236) are expected to be sufficiently low that their contribution would add less than $1 \%$ to the total uranium mass. As such, for the purpose of this report, the concentration of uranium-238 present in these samples is being considered the same as total uranium. 
Table 5.29 and Figure 5.6 contain the total acid-extractable and microwave-digestible uranium data (measured as $\mu \mathrm{g}$ uranium-238/g sediment on a dry weight basis) as a function of depth for sediments collected from well 399-3-22. Acid-extractable uranium concentrations ranged from a low of $0.332 \mu \mathrm{g} / \mathrm{g}$ to a maximum of $1.63 \mu \mathrm{g} / \mathrm{g}$. In comparison, the microwave digest method released more uranium from the sediments, with a range of 1.14 to $3.65 \mu \mathrm{g} / \mathrm{g}$. In every case, the microwave digests contained higher uranium concentrations. All of the microwave digests contained twice as much soluble uranium as their companion nitric acid extracts, and on average the microwave digests contained 2.8 times more uranium than the acid extracts. This finding was not surprising because the microwave digest method results in complete sample dissolution, whereas the $8 \mathrm{M}$ nitric acid extract is ineffective against recalcitrant minerals, such as the natural U(VI) minerals present in the native sediments. The peak uranium

Table 5.29. Acid-Extractable (AE) and Microwave-Digestible (MD) Uranium in Sediments from Well 399-3-22

\begin{tabular}{lccc}
\hline $\begin{array}{c}\text { Sample Name } \\
(\text { HEIS ID) }\end{array}$ & $\begin{array}{c}\text { Sample Mid Depth } \\
(\mathrm{ft} b \mathrm{gs})\end{array}$ & $\begin{array}{c}\text { AE Uranium-238 } \\
(\mu \mathrm{g} / \mathrm{g})\end{array}$ & $\begin{array}{c}\text { MD Uranium-238 } \\
(\mu \mathrm{g} / \mathrm{g})\end{array}$ \\
\hline B1PL37 & 30.0 & $4.47 \mathrm{E}-01$ & $1.14 \mathrm{E}+00$ \\
B1PL38 & 35.0 & $3.32 \mathrm{E}-01$ & $1.16 \mathrm{E}+00$ \\
B1PL56-2 & 41.2 & $7.12 \mathrm{E}-01$ & $1.48 \mathrm{E}+00$ \\
B1PL57-2 & 43.6 & $1.63 \mathrm{E}+00$ & $3.65 \mathrm{E}+00$ \\
B1PL58-2 & 61.0 & $4.04 \mathrm{E}-01$ & $1.24 \mathrm{E}+00$ \\
B1PL59-3 & 63.4 & $3.46 \mathrm{E}-01$ & $1.70 \mathrm{E}+00$ \\
B1PL60-1 & 67.5 & $1.15 \mathrm{E}+00$ & $2.83 \mathrm{E}+00$ \\
B1PL61-1 & 83.7 & $1.13 \mathrm{E}+00$ & $2.75 \mathrm{E}+00$ \\
B1PL61-1 DUP & 83.7 & $1.18 \mathrm{E}+00$ & $2.41 \mathrm{E}+00$ \\
\hline
\end{tabular}

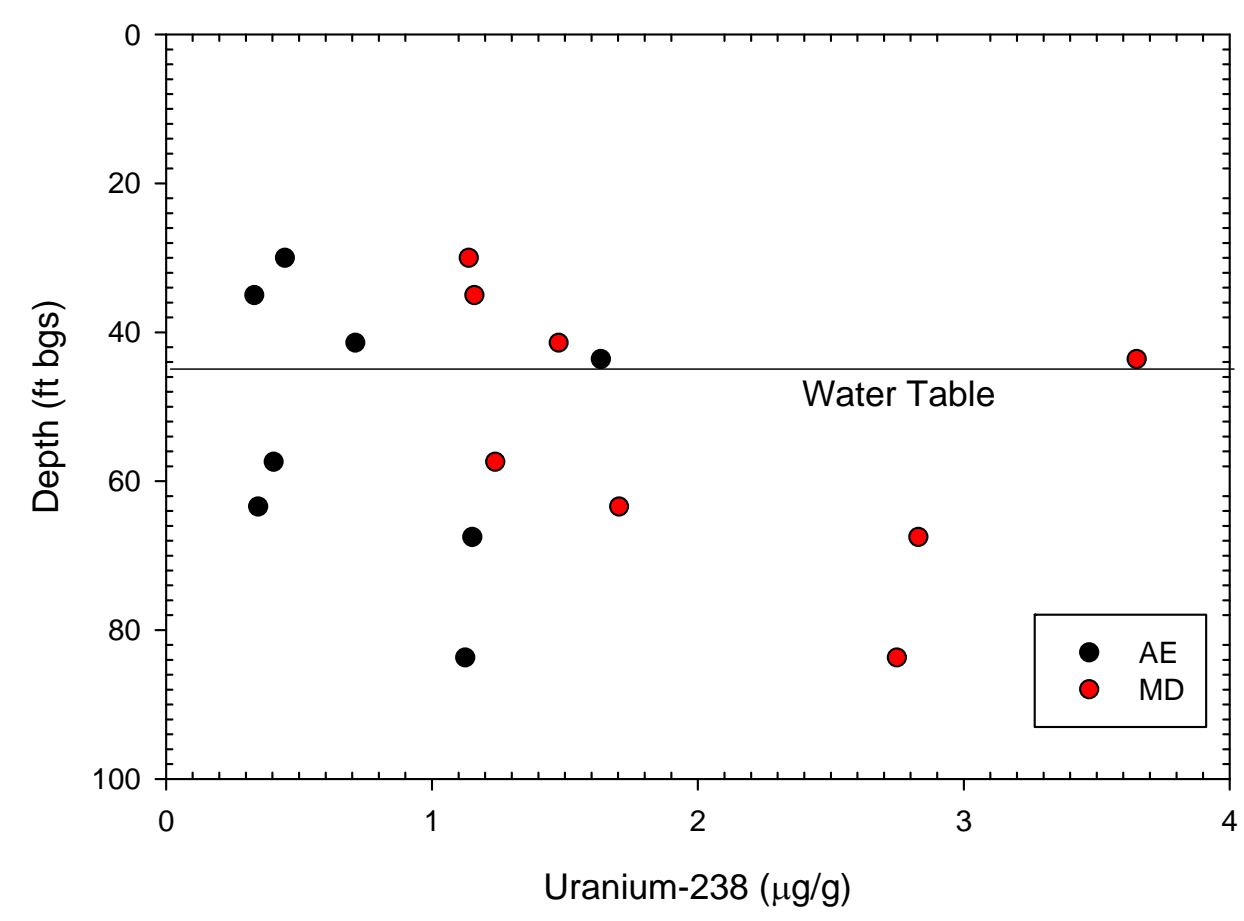

Figure 5.6. Concentration of Acid-Extractable (AE) and Microwave-Digestible (MD) Uranium-238 in Sediments from Well 399-2-5 
concentration measured in the sediments from well 399-3-22 was $3.65 \mu \mathrm{g} / \mathrm{g}$, while the peak concentration was $5.50 \mu \mathrm{g} / \mathrm{g}$ in sediments from well 399-2-5. Again, the peak uranium concentration was found in the sample collected very close to the top of the aquifer. Although the locations of wells 399-2-5 and 399-322 are considerably different, well 299-2-5 was emplaced through the SPP, while well 399-3-22 was well outside (approximately $65 \mathrm{~m}$ ) the footprint of the nearest 300 Area disposal facility (the SPP), the total concentration of contaminant uranium present in sediments from the two wells does not differ significantly. These results again do not support the previous hypothesis and subsequent box model of contaminant uranium inventory in the 300 Area vadose zone, which estimated a large distribution of contaminant uranium in the vadose zone directly beneath effluent disposal facilities (Peterson et al. 2008a). Instead, a new conceptual model in which there is a large inventory of sediments containing rather dilute concentrations of contaminant uranium, with the majority of the contaminant uranium residing in the lower vadose zone and capillary fringe, seems more plausible.

A comparison of the water-extractable versus acid-extractable and microwave-digestible uranium concentrations can be used to calculate an equilibrium $\mathrm{K}_{\mathrm{d}}$ (partition coefficient) for uranium. An equilibrium $\mathrm{K}_{\mathrm{d}}$ can be used to estimate the relative leachability of uranium in the 300 Area sediments, assuming that the 1:1 sediment:water extract acted solely as a mechanism to remove the entrapped pore water from the sediments. Again, although these samples were air-dried before performing the 1:1 sediment:water extract, it is reasonable to assume that the extract would have efficiently dissolved the constituents that precipitated upon drying of the samples. As mentioned previously, the assumption that none of the solid is dissolved during the water extraction process is simplistic. Therefore, the equilibrium $\mathrm{K}_{\mathrm{d}}$ values presented in Table 5.30 based on the 1:1 sediment:water extract results could be biased low (i.e., predicting greater release from the sediment).

The predicted equilibrium $\mathrm{K}_{\mathrm{d}}$ values presented in Table 5.30 vary considerably, with a range of 3.54 to $4640 \mathrm{~mL} / \mathrm{g}$ using the acid extracts versus a range of 7.41 to $11,400 \mathrm{~mL} / \mathrm{g}$ using the microwave digests. Note that the maximum reported $\mathrm{K}_{\mathrm{d}}$ values using both the acid and microwave digest data for well 399-3-22 were an order of magnitude higher than those for well 399-2-5. Additionally, the minimum reported $\mathrm{K}_{\mathrm{d}}$ values were also higher by an order of magnitude, at 3.54 and $7.41 \mathrm{~mL} / \mathrm{g}$ for the acid extracts and microwave digests, respectively. According to these data (and those from well 399-2-5), the uranium contamination present in the sediments has a low tendency to release into deionized water such that many

Table 5.30. Equilibrium $\mathrm{K}_{\mathrm{d}}$ Based on Water-Extractable (WE) Versus Acid-Extractable (AE) or Microwave-Digestible (MD) Uranium in Sediments from Well 399-3-22

\begin{tabular}{lccc}
\hline $\begin{array}{c}\text { Sample Name } \\
\text { (HEIS ID) }\end{array}$ & $\begin{array}{c}\text { Sample Mid Depth } \\
\text { (ft bgs) }\end{array}$ & $\begin{array}{c}\text { Equilibrium } \mathrm{K}_{\mathrm{d}} \text { based on WE } \\
\text { and AE Uranium-238 } \\
(\mathrm{mL} / \mathrm{g})\end{array}$ & $\begin{array}{c}\text { Equilibrium } \mathrm{K}_{\mathrm{d}} \text { based on WE } \\
\text { and MD Uranium-238 } \\
(\mathrm{mL} / \mathrm{g})\end{array}$ \\
\hline B1PL37 & 30.0 & $1.88 \mathrm{E}+01$ & $4.79 \mathrm{E}+01$ \\
B1PL38 & 35.0 & $1.14 \mathrm{E}+01$ & $3.98 \mathrm{E}+01$ \\
B1PL56-2 & 41.2 & $3.54 \mathrm{E}+00$ & $7.41 \mathrm{E}+00$ \\
B1PL57-2 & 43.6 & $1.67 \mathrm{E}+03$ & $3.73 \mathrm{E}+03$ \\
B1PL58-2 & 61.0 & $2.16 \mathrm{E}+01$ & $6.63 \mathrm{E}+01$ \\
B1PL59-3 & 63.4 & $1.46 \mathrm{E}+01$ & $7.21 \mathrm{E}+01$ \\
B1PL60-1 & 67.5 & $4.64 \mathrm{E}+03$ & $1.14 \mathrm{E}+04$ \\
B1PL61-1 & 83.7 & $1.47 \mathrm{E}+02$ & $3.59 \mathrm{E}+02$ \\
B1PL61-1 DUP & 83.7 & $1.68 \mathrm{E}+02$ & $3.41 \mathrm{E}+02$ \\
\hline
\end{tabular}


cycles of water washing of the sediments would be needed (assuming all of the uranium in the pore water gets flushed out of the system) to cleanse the sediments of the existing inventory in the sediments.

Interestingly, the sample with the lowest equilibrium $\mathrm{K}_{\mathrm{d}}$ value (highest potential to leach uranium) is the one located just above the water table in the capillary fringe (B1PL56-2). Even though its equilibrium $\mathrm{K}_{d}$ is much lower than other sample collected from well 399-3-22, sample B1PL56-2 will continue to slowly release its supply of contaminant uranium over several wetting and drying cycles for many years to come.

\subsubsection{Labile Uranium Leach Test Results}

The concentration of labile (easily removable fraction, such as ion exchangeable or water soluble) uranium in the air-dried sediments was measured using a sodium bicarbonate/carbonate mixed solution $\left(1.44 \times 10^{-2} \mathrm{M}\right.$ in $\mathrm{NaHCO}_{3}$ and $2.8 \times 10^{-3} \mathrm{M}$ in $\left.\mathrm{Na}_{2} \mathrm{CO}_{3}\right)$. The amount of uranium leached from the sediments was determined as a function of time, with sampling occurring after 1, 7, and 28 days of reaction. The goals of the time-dependent sampling are two-fold: time-based sampling enables determination of whether equilibrium (with respect to uranium solution concentrations) has been achieved in the reactors and allows making general comments or conclusions about the rate of uranium release from the sediments. Table 5.31 and Figure 5.7 contain the data from the time-dependent labile uranium leach test; the data are reported as $\mu \mathrm{g}$ uranium leached per gram of sediment on a dry weight basis. Like the carbonate leach results from well 399-2-5, the same two primary trends are evident in the data from well 399-3-22. The first trend involves a rather rapid release of uranium (approximately $85 \%$ of the total carbonate leachable fraction) from the sediment; the second can be characterized as a slow, continual release of uranium from the sediments. The kinetics of the second trend appears to extend beyond 28 days of reaction time because steady-state uranium solution concentrations were not achieved for any of the samples analyzed. The two trends evident in this experiment likely result from at least two types of uranium being present in the sediments. The first, which readily leaches upon contact with the carbonate/ bicarbonate solution, is likely present as an easily removable sorbed species. Conversely, the remaining uranium that can be characterized as having a very slow leach rate is likely present as discrete uraniumbearing minerals (Serne et al. 2002a) or as uranium microprecipitates that appear to be concentrated in fractures in feldspar crystals within granitic lithic fragments (Liu et al. 2004, 2006; McKinley et al. 2006). However, this slow, kinetically controlled desorption of uranium can also result from more resistant uranium incorporation into (physical entrapment) or onto (sorption) nanocrystalline iron oxide coatings, as proposed by Bond et al. (2008).

When the total amount of labile uranium (as measured via the 28 day sampling event) is used to calculate $\mathrm{K}_{\mathrm{d}}$ values, a considerably different picture becomes evident. First of all, the calculated $\mathrm{K}_{\mathrm{d}}$ values are considerably lower, ranging from 0.485 to $994 \mathrm{~mL} / \mathrm{g}$. It is interesting that the sample with the highest amount of carbonate-leachable uranium also has the highest equilibrium $\mathrm{K}_{d}$ (based on 1:1 sediment:water extract data). Specifically, sample B1PL57-2 had an equilibrium $K_{d}$ value of $994 \mathrm{~mL} / \mathrm{g}$. This result implies that the inventory of uranium present at the interface of the vadose zone and aquifer (i.e., the capillary fringe) has the potential to supply the aquifer with contaminant uranium for a substantial period of time. The contaminant uranium present shallower in the vadose zone and deeper (through $64 \mathrm{ft}$ bgs) within the aquifer is considerably more mobile, with equilibrium $K_{d}$ values of $2 \mathrm{~mL} / \mathrm{g}$ or less. The uranium present below $64 \mathrm{ft}$ bgs is held more tightly within the fine-grained matrix of the Ringold Formation. 
Table 5.31. Labile Uranium Concentrations as a Function of Time in Sediments from Well 399-3-22

\begin{tabular}{lcccc}
\hline $\begin{array}{c}\text { Sample Name } \\
(\text { HEIS ID) }\end{array}$ & $\begin{array}{c}\text { Sample Mid Depth } \\
(\mathrm{ft} b g s)\end{array}$ & $\begin{array}{c}\text { Labile Uranium } \\
\text { Time= 1 Day } \\
(\mu \mathrm{g} / \mathrm{g})\end{array}$ & $\begin{array}{c}\text { Labile Uranium } \\
\text { Time }=7 \text { Days } \\
(\mu \mathrm{g} / \mathrm{g})\end{array}$ & $\begin{array}{c}\text { Labile Uranium } \\
\text { Time }=28 \text { Days } \\
(\mu \mathrm{g} / \mathrm{g})\end{array}$ \\
\hline B1PL37 & 30.0 & $1.05 \mathrm{E}-02$ & $1.68 \mathrm{E}-02$ & $2.09 \mathrm{E}-02$ \\
B1PL38 & 35.0 & $7.07 \mathrm{E}-03$ & $1.26 \mathrm{E}-02$ & $1.53 \mathrm{E}-02$ \\
B1PL56-2 & 41.2 & $1.27 \mathrm{E}-01$ & $2.30 \mathrm{E}-01$ & $2.67 \mathrm{E}-01$ \\
B1PL57-2 & 43.6 & $4.20 \mathrm{E}-01$ & $7.88 \mathrm{E}-01$ & $9.72 \mathrm{E}-01$ \\
B1PL58-2 & 61.0 & $1.89 \mathrm{E}-02$ & $2.71 \mathrm{E}-02$ & $3.45 \mathrm{E}-02$ \\
B1PL59-3 & 63.4 & $2.17 \mathrm{E}-02$ & $3.64 \mathrm{E}-02$ & $4.69 \mathrm{E}-02$ \\
B1PL60-1 & 67.5 & $5.62 \mathrm{E}-02$ & $1.38 \mathrm{E}-01$ & $1.89 \mathrm{E}-01$ \\
B1PL61-1 & 83.7 & $2.14 \mathrm{E}-01$ & $3.82 \mathrm{E}-01$ & $5.01 \mathrm{E}-01$ \\
B1PL61-1 DUP & 83.7 & $7.60 \mathrm{E}-02$ & $1.03 \mathrm{E}-01$ & $1.25 \mathrm{E}-01$ \\
\hline
\end{tabular}

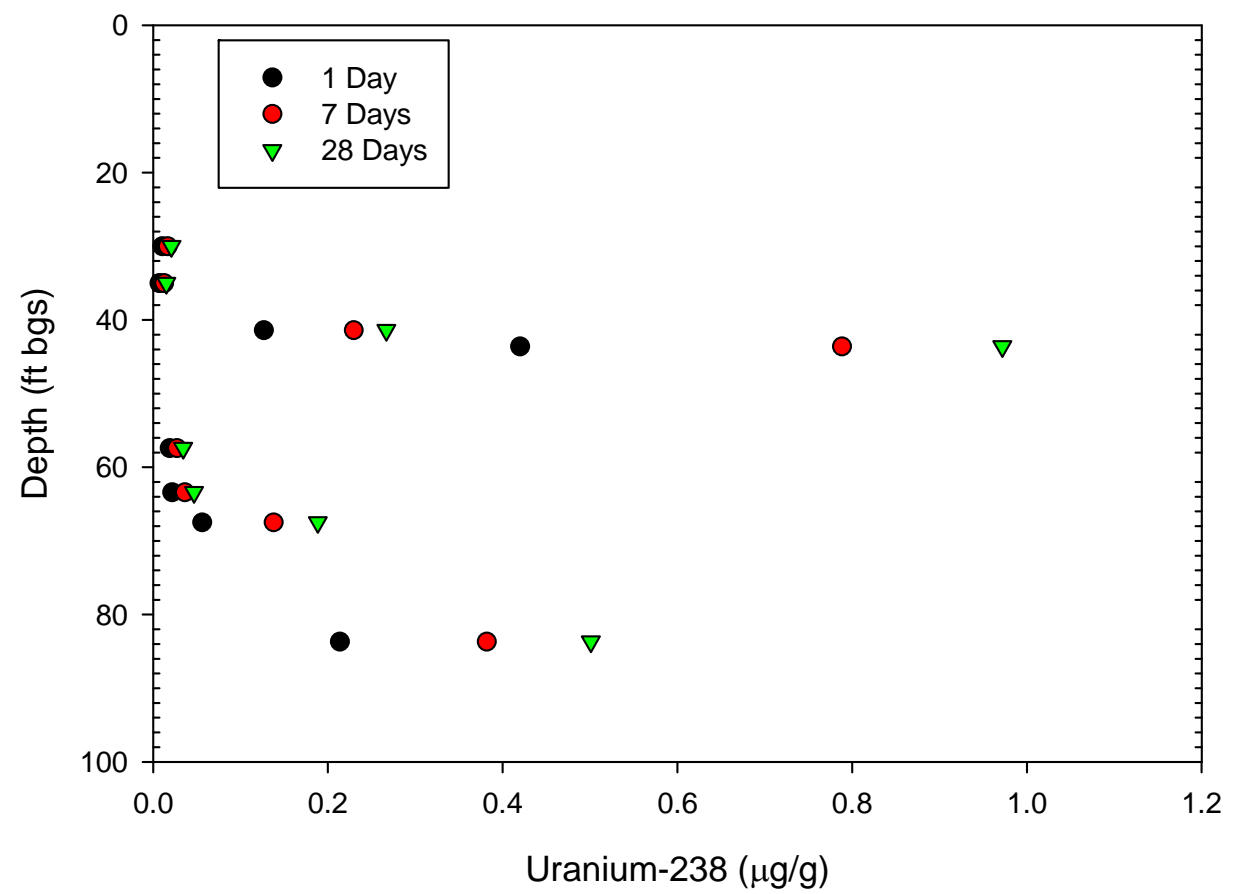

Figure 5.7. Concentration of Labile Uranium-238 in Sediments from Well 399-3-22

Table 5.32. Equilibrium $\mathrm{K}_{\mathrm{d}}$ Based on Labile Uranium 28 Day Sample Versus Water-Extractable (WE) Uranium in Sediments from Well 399-3-22

\begin{tabular}{|c|c|c|}
\hline $\begin{array}{l}\text { Sample Name } \\
\text { (HEIS ID) }\end{array}$ & $\begin{array}{l}\text { Sample Mid Depth } \\
\text { (ft bgs) }\end{array}$ & $\begin{array}{c}\text { Equilibrium } \mathrm{K}_{\mathrm{d}} \text { based on } \\
\text { 28-Day Sample and } \mathrm{WE}^{238} \mathrm{U} \\
(\mathrm{mL} / \mathrm{g})\end{array}$ \\
\hline B1PL37 & 30.0 & $8.37 \mathrm{E}-01$ \\
\hline B1PL38 & 35.0 & $4.85 \mathrm{E}-01$ \\
\hline B1PL56-2 & 41.2 & $1.29 \mathrm{E}+00$ \\
\hline B1PL57-2 & 43.6 & $9.94 \mathrm{E}+02$ \\
\hline B1PL58-2 & 61.0 & $1.81 \mathrm{E}+00$ \\
\hline B1PL59-3 & 63.4 & $1.90 \mathrm{E}+00$ \\
\hline B1PL60-1 & 67.5 & $7.59 \mathrm{E}+02$ \\
\hline B1PL61-1 & 83.7 & $6.51 \mathrm{E}+01$ \\
\hline B1PL61-1 DUP & 83.7 & $1.75 \mathrm{E}+01$ \\
\hline
\end{tabular}




\subsubsection{Total Carbon, Calcium Carbonate, and Organic Carbon Content of Sediment from Well 399-3-22}

Data from the total carbon, inorganic carbon, and organic carbon (calculated by difference) content of the sediments collected during the drilling of well 399-3-22 are shown in Table 5.33. Inorganic carbon was only quantified in two of the samples from well 399-3-22; the estimated quantification limit for the nonreportable samples ranged from 1.54E-02 to $4.52 \mathrm{E}-02 \mathrm{wt} \%$. Total carbon concentrations in the samples ranged from 2.21E-02 to $9.51 \mathrm{E}-02 \mathrm{wt} \%$. For the samples in which inorganic carbon was not detected above the limit of quantification, the signal measured as total carbon has been entirely attributed to organic carbon. The concentrations of organic carbon measured in these samples compare well with those measured in boreholes C4999, C5000, C5001, and C5002, which all contained subpercent levels of organic carbon (Williams et al. 2007).

Table 5.33. Total, Inorganic, and Organic Carbon Content of Sediments from Well 399-3-22 (a)

\begin{tabular}{lcccc}
\hline $\begin{array}{c}\text { Sample Name } \\
\text { (HEIS ID) }\end{array}$ & $\begin{array}{c}\text { Sample Mid } \\
\text { Depth } \\
(\mathrm{ft} \mathrm{bgs)}\end{array}$ & $\begin{array}{c}\text { Total } \\
\text { Carbon } \\
(\%)\end{array}$ & $\begin{array}{c}\text { Inorganic } \\
\text { Carbon } \\
(\%)\end{array}$ & $\begin{array}{c}\text { Organic } \\
\text { Carbon } \\
\text { (by difference) }\end{array}$ \\
\hline B1PL37 & 30.0 & $7.16 \mathrm{E}-02$ & $6.01 \mathrm{E}-02$ & $1.15 \mathrm{E}-02$ \\
B1PL38 & 35.0 & $9.51 \mathrm{E}-02$ & $7.25 \mathrm{E}-02$ & $2.26 \mathrm{E}-02$ \\
B1PL56-2 & 41.2 & $6.48 \mathrm{E}-02$ & $<1.54 \mathrm{E}-02$ & $6.48 \mathrm{E}-02$ \\
B1PL57-2 & 43.6 & $3.48 \mathrm{E}-02$ & $<2.87 \mathrm{E}-02$ & $3.48 \mathrm{E}-02$ \\
B1PL58-2 & 61.0 & $3.91 \mathrm{E}-02$ & $<2.56 \mathrm{E}-02$ & $3.91 \mathrm{E}-02$ \\
B1PL59-3 & 63.4 & $3.31 \mathrm{E}-02$ & $<3.02 \mathrm{E}-02$ & $3.31 \mathrm{E}-02$ \\
B1PL60-1 & 67.5 & $2.42 \mathrm{E}-02$ & $<4.14 \mathrm{E}-02$ & $2.42 \mathrm{E}-02$ \\
B1PL61-1 & 83.7 & $2.21 \mathrm{E}-02$ & $<4.52 \mathrm{E}-02$ & $2.21 \mathrm{E}-02$ \\
B1PL61-1 DUP & 83.7 & $2.97 \mathrm{E}-02$ & $<3.37 \mathrm{E}-02$ & $2.97 \mathrm{E}-02$ \\
\hline
\end{tabular}

(a) < symbol indicates the analyte was below the detection limit. The minimum detection limit has been reported.

\subsubsection{Analysis of Groundwater Samples from Well 399-3-22}

Groundwater samples analyzed by WSCF are presented in Tables 5.34 and 5.35 in units of meq/L to facilitate comparison to the UFA extract and 1:1 sediment:water pore water corrected data presented earlier. The groundwater samples had an average dissolved anion content of $3.61 \mathrm{meq} / \mathrm{L}$. The primary anionic species in the groundwater samples was alkalinity (bicarbonate), with a range of 2.4 to $3.2 \mathrm{meq} / \mathrm{L}$. The remaining negative charge came from sulfate, chloride, and nitrate (note that the groundwater samples were analyzed for fewer elements than the water and UFA extract samples). The anionic charge in the groundwater samples was primarily balanced by calcium (average concentration of $1.75 \mathrm{meq} / \mathrm{L}$ ), with lesser amounts of sodium, magnesium, potassium, and strontium. Overall, the charge balance between anions and cations was good. The percent difference between dissolved anions and cations in the groundwater samples from well 399-3-22 varied from 0.2 to 7.5\%, indicating that, while WSCF analyzed the groundwater samples for fewer anions, their analysis has captured the major constituents in the samples. 
Table 5.34. Major Anions in Groundwater Samples from Well 399-3-22

\begin{tabular}{cccccc}
\hline $\begin{array}{c}\text { Sample Name } \\
\text { (HEIS ID) }\end{array}$ & $\begin{array}{c}\text { Sample } \\
\text { Mid Depth } \\
\text { (ft bgs) }\end{array}$ & $\begin{array}{c}\text { Chloride } \\
(\mathrm{meq} / \mathrm{L})\end{array}$ & $\begin{array}{c}\text { Nitrate } \\
(\mathrm{meq} / \mathrm{L})\end{array}$ & $\begin{array}{c}\text { Sulfate } \\
(\mathrm{meq} / \mathrm{L})\end{array}$ & $\begin{array}{c}\text { Alkalinity } \\
\text { as CO }_{3}^{2-} \\
(\mathrm{meq} / \mathrm{L})\end{array}$ \\
\hline B1PLB2 & 49.0 & $4.82 \mathrm{E}-01$ & $3.68 \mathrm{E}-01$ & $8.06 \mathrm{E}-01$ & $2.40 \mathrm{E}+00$ \\
B1PLB3 & 54.3 & $4.63 \mathrm{E}-01$ & $3.60 \mathrm{E}-01$ & $8.35 \mathrm{E}-01$ & $2.40 \mathrm{E}+00$ \\
B1PLB4 & 63.3 & $4.57 \mathrm{E}-01$ & $3.53 \mathrm{E}-01$ & $8.35 \mathrm{E}-01$ & $2.40 \mathrm{E}+00$ \\
B1PLB5 & 81.8 & $1.23 \mathrm{E}-01$ & $4.50 \mathrm{E}-03$ & $2.17 \mathrm{E}-01$ & $2.60 \mathrm{E}+00$ \\
B1PLB6 & 94.5 & $1.68 \mathrm{E}-01$ & $9.27 \mathrm{E}-04$ & $1.78 \mathrm{E}-01$ & $3.20 \mathrm{E}+00$ \\
B1PLB7 & 108.5 & $1.67 \mathrm{E}-01$ & $3.56 \mathrm{E}-04$ & $6.67 \mathrm{E}-03$ & $3.20 \mathrm{E}+00$ \\
B1PLB8 & 121.5 & $1.79 \mathrm{E}-01$ & $4.29 \mathrm{E}-04$ & $2.54 \mathrm{E}-02$ & $3.20 \mathrm{E}+00$ \\
B1PLB9 & 131.5 & $2.67 \mathrm{E}-01$ & $3.56 \mathrm{E}-04$ & $8.06 \mathrm{E}-01$ & $3.20 \mathrm{E}+00$ \\
\hline
\end{tabular}

Table 5.35. Major Cations in Groundwater Samples from Well 399-3-22

\begin{tabular}{cccccc}
\hline $\begin{array}{c}\text { Sample Name } \\
\text { (HEIS ID) }\end{array}$ & $\begin{array}{c}\text { Sample } \\
\text { Mid Depth } \\
\text { (ft bgs) }\end{array}$ & $\begin{array}{c}\text { Calcium } \\
\text { (meq/L) }\end{array}$ & $\begin{array}{c}\text { Potassium } \\
\text { (meq/L) }\end{array}$ & $\begin{array}{c}\text { Magnesium } \\
\text { (meq/L) }\end{array}$ & $\begin{array}{c}\text { Sodium } \\
\text { (meq/L) }\end{array}$ \\
\hline B1PLB2 & 49.0 & $2.36 \mathrm{E}+00$ & $1.43 \mathrm{E}-01$ & $7.98 \mathrm{E}-01$ & $9.00 \mathrm{E}-01$ \\
B1PLB3 & 54.3 & $2.40 \mathrm{E}+00$ & $1.46 \mathrm{E}-01$ & $8.10 \mathrm{E}-01$ & $8.96 \mathrm{E}-01$ \\
B1PLB4 & 63.3 & $2.09 \mathrm{E}+00$ & $1.64 \mathrm{E}-01$ & $7.37 \mathrm{E}-01$ & $9.22 \mathrm{E}-01$ \\
B1PLB5 & 81.8 & $1.62 \mathrm{E}+00$ & $1.36 \mathrm{E}-01$ & $5.27 \mathrm{E}-01$ & $7.09 \mathrm{E}-01$ \\
B1PLB6 & 94.5 & $1.56 \mathrm{E}+00$ & $1.82 \mathrm{E}-01$ & $5.37 \mathrm{E}-01$ & $1.02 \mathrm{E}+00$ \\
B1PLB7 & 108.5 & $1.35 \mathrm{E}+00$ & $1.80 \mathrm{E}-01$ & $7.03 \mathrm{E}-01$ & $1.05 \mathrm{E}+00$ \\
B1PLB8 & 121.5 & $1.29 \mathrm{E}+00$ & $1.84 \mathrm{E}-01$ & $7.11 \mathrm{E}-01$ & $1.21 \mathrm{E}+00$ \\
B1PLB9 & 131.5 & $1.32 \mathrm{E}+00$ & $2.61 \mathrm{E}-01$ & $6.85 \mathrm{E}-01$ & $1.47 \mathrm{E}+00$ \\
\hline
\end{tabular}

Comparing the total concentration of anions and cations in the groundwater samples with those measured in the water and UFA extracts identified that the groundwater samples were similar to the other extracts within the Hanford formation but much more dilute than either of the extracts in the Ringold Formation. In the Hanford formation, the pore water-corrected water extract of sample B1PL57-2 had a total dissolved salt load of $8.29 \mathrm{meq} / \mathrm{L}$; the UFA extract had a dissolved salt load of $6.25 \mathrm{meq} / \mathrm{L}$. Groundwater sample B1PLB2, which was the groundwater sample collected closest to sample B1PL57-2, had a dissolved salt load of $8.26 \mathrm{meq} / \mathrm{L}$. Although this is only a single data point, these results imply that the water extraction of sediment collected within the capillary fringe did not result in an overestimation of the sediments pore water chemistry. In the Ringold Formation, the pore water-corrected water extract of sample B1PL61-1 had a total dissolved salt load of $13.2 \mathrm{meq} / \mathrm{L}$, while the UFA extract had a dissolved salt load of $22.5 \mathrm{meq} / \mathrm{L}$. Groundwater samples B1PLB5 and B1PLB6, which were collected closest to sample B1PL61-1, had dissolved salt loads of 5.94 and $6.85 \mathrm{meq} / \mathrm{L}$, respectively. Based on these data, the groundwater samples are approximately $45 \%$ as concentrated as the water extract sample and $25 \%$ as concentrated as the UFA extract. Sulfate is the anion with the largest discrepancy between water and UFA extracts and groundwater samples. The concentration of dissolved sulfate in the groundwater samples was $<1 \mathrm{meq} / \mathrm{L}$ and approximately 5 and $10 \mathrm{meq} / \mathrm{L}$ in the water and UFA extracts, respectively. Calcium is the corresponding cation with the poorest agreement among the datasets, indicating that the dissolution of a calcium sulfate mineral (such as gypsum) could be altering the chemical composition of the water and UFA extracts. Unlike the samples analyzed from well 399-2-5, the carbonate concentration in the groundwater was higher than that measured in the UFA or water extracts, which could indicate precipitation of calcite in the water extract samples. Serne et al. (2002a) noted that that pore waters extracted from the 300 Area sediments were often at or very near saturation with respect to calcite. 
The concentration of uranium-238 in the groundwater samples, as measured by WSCF, is reported in Table 5.36. The majority of the contaminant uranium in the aquifer resides in the gravel-dominated Hanford formation rather than in the finer-grained Ringold Formation. In fact, groundwater samples collected within the Ringold Formation had uranium concentrations of $<1 \mu \mathrm{g} / \mathrm{L}$, while concentrations were 12 to $20 \mu \mathrm{g} / \mathrm{L}$ in the Hanford formation. Additionally, there was a decreasing trend in uranium concentrations within the aquifer as a function of depth such that the two deepest samples analyzed were both reported as less than WSCF's limit of quantification $(0.05 \mu \mathrm{g} / \mathrm{L})$.

Of all the samples taken through the water and UFA extraction process, only two were retrieved from similar depths for which groundwater data are available (samples B1PL58-3 and B1PL61-1). Comparison of these data with those generated from analysis of the groundwater samples found some surprises. Water extract data of sample B1PL58-3 correlated well with the available groundwater data; however, the UFA extract data appears to be biased high by a factor of 10. Agreement between the three analyses for the samples collected at approximately $82 \mathrm{ft}$ bgs was even poorer. The uranium concentration measured in the groundwater was $0.162 \mu \mathrm{g} / \mathrm{L}$, compared to approximately $7.3 \mu \mathrm{g} / \mathrm{L}$ for the pore water-corrected water extract and $24 \mu \mathrm{g} / \mathrm{L}$ in the UFA extract. Thus, there is a factor of $\sim 100 \mathrm{X}$ difference within the range of values. The high concentration of uranium from 1:1 water and UFA extraction of sediments collected from depths at which very little groundwater contamination exists is perplexing. The water and UFA extracts were performed on sediments less than $2 \mathrm{~mm}$ in diameter, while the groundwater samples were in contact with the entire lithology of the Ringold Formation finer-grained unit. While this sampling bias could lead to an overestimation of the uranium content in water and UFA extraction, it cannot be used to explain the major discrepancies observed in this dataset. It is improbable to think that the saturated Ringold Formation sediments could contain enough contaminant uranium to generate the solution concentration measured in water and particularly UFA extracts. Given that this small dataset does not conform to the results seen in well 399-2-5, in which the groundwater had higher overall uranium concentrations, all that can be said at this time is that the anomalies observed warrant more thorough investigation.

Table 5.36. Uranium Concentrations in Groundwater Samples from Well 399-3-22

\begin{tabular}{ccc}
\hline $\begin{array}{c}\text { Sample Name } \\
(\text { HEIS ID) }\end{array}$ & $\begin{array}{c}\text { Sample Mid Depth } \\
(\mathrm{ft} \mathrm{bgs})\end{array}$ & $\begin{array}{c}\text { Uranium-238 } \\
(\mu \mathrm{g} / \mathrm{L})\end{array}$ \\
\hline B1PLB2 & 49.0 & $1.90 \mathrm{E}+01$ \\
B1PLB3 & 54.3 & $1.98 \mathrm{E}+01$ \\
B1PLB4 & 63.3 & $1.16 \mathrm{E}+01$ \\
B1PLB5 & 81.8 & $1.62 \mathrm{E}-01$ \\
B1PLB6 & 94.5 & $6.85 \mathrm{E}-01$ \\
B1PLB7 & 108.5 & $<5.00 \mathrm{E}-02$ \\
B1PLB8 & 121.5 & $<5.00 \mathrm{E}-02$ \\
B1PLB9 & 131.5 & $2.58 \mathrm{E}-01$ \\
\hline
\end{tabular}

(a) $<$ symbol indicates the analyte was below the detection limit. The minimum detection limit has been reported. 


\subsection{Sediment from Well 399-4-14 (Borehole C5707)}

\subsubsection{Moisture Content}

The moisture content of the 18 core liners, one grab sample, and nine moisture tins collected while drilling well 399-4-14 is listed as a function of depth in Table 5.37. The moisture content profile correlates with the lithology presented in Section 4 and Table 4.1. In general, the gravel-dominated vadose zone sediment of the Hanford formation had low moisture content, with an average in the vadose zone of $8.20 \mathrm{wt} \%$. Unlike the other two boreholes analyzed in this study, the vadose zone sediments from well 399-4-14 were less variable, and the few occurrences of very fine-grained sediment that were observed in the Hanford formation in wells 399-2-5 and 399-3-22 were not captured in the sampling campaign for well 399-4-14. The remaining Hanford and Ringold formation sediments were collected below the water table (located at approximately $44 \mathrm{ft}$ bgs); therefore, their measured moisture contents reflect the ability of the sediments to retain pore water as they were brought to the surface in the core barrel. The measured moisture content of the samples can be used to qualitatively identify the location (depth) of finer-grained material in this borehole. This qualitative assessment confirms the lithology described in Table 4.1 indicating that the Ringold Formation undesignated finer-grained interval began at about $67 \mathrm{ft}$ bgs at this location and extended to the terminus depth from which samples were analyzed ( $80 \mathrm{ft} \mathrm{bgs).}$

Table 5.37. Gravimetric Moisture Content of Samples Retrieved from Well 399-4-14

\begin{tabular}{lcc}
\hline $\begin{array}{c}\text { Sample Name } \\
\text { (HEIS ID) }\end{array}$ & $\begin{array}{c}\text { Sample Mid Depth } \\
(\mathrm{ft} \text { bgs })\end{array}$ & $\begin{array}{c}\text { Moisture Content } \\
(\mathrm{wt} \%)\end{array}$ \\
\hline B1PL39 & 10.0 & $5.34 \%$ \\
B1PL40 & 15.0 & $3.23 \%$ \\
B1PL41 & 20.0 & $4.19 \%$ \\
B1PL42 & 25.0 & $8.99 \%$ \\
B1PL43 & 27.0 & $8.01 \%$ \\
B1PL62-4 & 28.4 & $9.32 \%$ \\
B1PL62-3 & 29.1 & $5.02 \%$ \\
B1PL62-2 & 29.9 & $4.95 \%$ \\
B1PL62-1 & 30.6 & $5.85 \%$ \\
B1PL44 & 31.0 & $8.87 \%$ \\
B1PL63-4 & 31.5 & $8.77 \%$ \\
B1PL63-3 & 32.5 & $7.18 \%$ \\
B1PL63-2 & 33.5 & $8.29 \%$ \\
B1R086 & 34.0 & $10.7 \%$ \\
B1PL64-4 & 34.5 & $11.2 \%$ \\
B1PL64-3 & 35.5 & $8.28 \%$ \\
B1PL64-2 & 36.5 & $11.1 \%$ \\
B1R087 & 37.0 & $10.3 \%$ \\
B1PL65-4 & 39.5 & $10.9 \%$ \\
B1PL65-3 & 40.5 & $10.1 \%$ \\
B1PL65-2 & 41.5 & $9.18 \%$ \\
B1R088 & 42.0 & $10.5 \%$ \\
B1R089 & 44.5 & $4.97 \%$ \\
C5707-43 & 43.0 & $1.84 \%$ \\
B1PL66-4 & 78.8 & $23.1 \%$ \\
B1PL66-3 & 79.3 & $20.0 \%$ \\
B1PL66-2 & 79.8 & $17.3 \%$ \\
B1PL66-1 & 80.3 & $17.2 \%$ \\
\hline
\end{tabular}




\subsubsection{1:1 Sediment:Water Extracts of Sediments from Well 399-4-14}

A subset of sediments from well 399-4-14 was characterized by performing 1:1 sediment:water extracts. The tables in this section present the mass of a given constituent leached per gram of sediment measured in the water extracts. Other figures show dilution-corrected values that represent concentrations in vadose zone pore water. As mentioned previously, the assumption that none of the solid is dissolved during the water extraction process is simplistic. Further comparisons are made in later sections between calculated pore water concentrations and those directly extracted from the sediments using a UFA.

\subsubsection{1 pH and Electrical Conductivity}

The $\mathrm{pH}$ and $\mathrm{EC}$ values of the water extracts from select samples from well 399-4-14 are shown in Table 5.38. Both geochemical parameters are tabulated as measured in the 1:1 sediment:water extracts. However, the measured EC values have also been corrected back to a pore water concentration based on field-moist moisture content and are reported as pore water-corrected in Table 5.37. The $\mathrm{pH}$ profile is fairly constant with all values between 7.5 and 8.4 (the typical range for Hanford sediments). The pore water-corrected EC data are more variable, ranging from 2.24 to $15.3 \mathrm{mS} / \mathrm{cm}$ in the Hanford formation and $0.664 \mathrm{mS} / \mathrm{cm}$ for the only sample analyzed from the Ringold Formation. The one sample exhibiting an elevated pore water-corrected EC value (C5707-43) was biased due to lack of a representative sample. Sample C5707-43 consisted primarily of gravel and rocks; therefore, it had a very low moisture content $(1.84 \mathrm{wt} \%)$. In general, pore water corrected data becomes significantly biased high when very dry samples are encountered; therefore, the pore water-corrected EC data for sample C5707-43 should be considered biased high. The calculated pore water conductivities of the remaining samples collected from well 399-4-14 were quite dilute $(0.664$ to $3.57 \mathrm{mS} / \mathrm{cm})$ and compared well with pore water conductivity data measured in other 300 Area boreholes (Williams et al. 2007). Pore water conductivities ranged from 1.43 to $4.51 \mathrm{mS} / \mathrm{cm}$ in borehole C5001 and from 1.96 to 4.84 in borehole C5002.

Table 5.38. $\mathrm{pH}$ for 1:1 Sediment:Water Extracts and Dilution-Corrected EC Values from Well 399-4-14

\begin{tabular}{lcccc}
\hline $\begin{array}{c}\text { Sample Name } \\
\text { (HEIS ID) }\end{array}$ & $\begin{array}{c}\text { Sample Mid Depth } \\
(\mathrm{ft} \mathrm{bgs})\end{array}$ & $\mathrm{pH}$ & $\begin{array}{c}\mathrm{EC} \\
(\mathrm{mS} / \mathrm{cm})\end{array}$ & $\begin{array}{c}\text { Pore Water-Corrected } \\
\text { Conductivity }(\mathrm{mS} / \mathrm{cm})\end{array}$ \\
\hline B1PL64-4 & 34.5 & 7.95 & $4.00 \mathrm{E}-01$ & $3.57 \mathrm{E}+00$ \\
B1PL64-3 & 35.5 & 8.11 & $2.92 \mathrm{E}-01$ & $3.53 \mathrm{E}+00$ \\
B1PL64-2 & 36.5 & 7.67 & $2.51 \mathrm{E}-01$ & $2.24 \mathrm{E}+00$ \\
B1PL64-2 DUP & 36.5 & 7.93 & $2.57 \mathrm{E}-01$ & $2.30 \mathrm{E}+00$ \\
B1PL65-2 & 41.5 & 7.56 & $3.23 \mathrm{E}-01$ & $3.52 \mathrm{E}+00$ \\
C5707-43 & 43.0 & 7.79 & $2.80 \mathrm{E}-01$ & $1.53 \mathrm{E}+01$ \\
B1PL66-1 & 80.3 & 8.35 & $1.14 \mathrm{E}-01$ & $6.64 \mathrm{E}-01$ \\
\hline
\end{tabular}

\subsubsection{Composition of the 1:1 Sediment:Water Extracts from Well 399-4-14}

Of the three wells analyzed as part of this study, well 399-4-14 was designated to have the least amount of characterization performed. As such, the data contained in the following sections and tables is sparser than for the other two wells. The concentrations of major anions, cations, and several trace constituents are discussed in this section. The anion data are tabulated in Table 5.39 in units of mass per gram of dry sediment. The primary water-extractable anion in both the Hanford and Ringold formations was alkalinity (bicarbonate). A comparison of the masses of water-extractable anions per gram of sediment from the Hanford and Ringold formation units in well 399-4-14 showed that there were some 
differences in the anion composition between the two formations. Namely, the water-extractable concentrations of chloride, nitrate, and sulfate differed significantly between the Hanford formation and Ringold Formation sediments. For example, the average chloride, nitrate, and sulfate concentrations of the three Hanford formation samples analyzed were $22.4,10.9$, and $21.5 \mu \mathrm{g} / \mathrm{g}$, respectively. The one sample analyzed from the Ringold Formation had water extractable chloride, nitrate, and sulfate concentrations of $1.23,<1.00$ (less than quantifiable), and $3.34 \mu / \mathrm{g}$, respectively. The elevated nitrate is likely a result of liquid waste discharged to a 300 Area waste site; although no known disposal facilities are located proximal to this well. A similar source is likely responsible for the elevated chloride observed in the Hanford formation vadose zone sediments. The peak water-extractable chloride concentration of $30.5 \mathrm{mg} / \mathrm{g}$ is more than a factor of two higher than the peak values measured in sediments from the 316 SPP (well 399-2-5). Finally, the sulfate concentrations measured in the three Hanford formation samples were a factor of 4 to 5 higher than the values reported for background 300 Area sediment (Serne et al. 2002a). These results confirm the presence of residual waste in the vadose zone at this location.

Table 5.39. Water-Extractable Anions in Sediments from Well 399-4-14 ( $\mu \mathrm{g} / \mathrm{g}$ dry sediment) ${ }^{(\mathrm{a})}$

\begin{tabular}{lccccccc}
\hline $\begin{array}{c}\text { Sample Name } \\
\text { (HEIS ID) }\end{array}$ & $\begin{array}{c}\text { Sample } \\
\text { Mid Depth } \\
(\mathrm{ft} \text { bgs })\end{array}$ & $\begin{array}{c}\text { Fluoride } \\
(\mu \mathrm{g} / \mathrm{g})\end{array}$ & $\begin{array}{c}\text { Chloride } \\
(\mu \mathrm{g} / \mathrm{g})\end{array}$ & $\begin{array}{c}\text { Nitrate } \\
(\mu \mathrm{g} / \mathrm{g})\end{array}$ & $\begin{array}{c}\text { Sulfate } \\
(\mu \mathrm{g} / \mathrm{g})\end{array}$ & $\begin{array}{c}\text { Phosphate } \\
(\mu \mathrm{g} / \mathrm{g})\end{array}$ & $\begin{array}{c}\text { Alkalinity } \\
\text { as CaCO } \\
(\mu \mathrm{g} / \mathrm{g})\end{array}$ \\
\hline B1PL64-2 & 36.5 & $7.18 \mathrm{E}-01$ & $1.10 \mathrm{E}+01$ & $9.72 \mathrm{E}+00$ & $1.79 \mathrm{E}+01$ & $<1.50 \mathrm{E}+00$ & $7.75 \mathrm{E}+01$ \\
B1PL65-2 & 41.5 & $8.15 \mathrm{E}-01$ & $3.05 \mathrm{E}+01$ & $1.89 \mathrm{E}+01$ & $1.97 \mathrm{E}+01$ & $<1.50 \mathrm{E}+00$ & $7.07 \mathrm{E}+01$ \\
C5707-43 & 43.0 & $8.00 \mathrm{E}-01$ & $2.57 \mathrm{E}+01$ & $3.98 \mathrm{E}+00$ & $2.69 \mathrm{E}+01$ & $<1.51 \mathrm{E}+00$ & $6.54 \mathrm{E}+01$ \\
B1PL66-1 & 80.3 & $2.53 \mathrm{E}-01$ & $1.28 \mathrm{E}+00$ & $<1.00 \mathrm{E}+00$ & $3.34 \mathrm{E}+00$ & $<1.50 \mathrm{E}+00$ & $5.32 \mathrm{E}+01$ \\
\hline (a) $<$ symbol indicates the analyte was below the detection limit. The minimum detection limit has been reported.
\end{tabular}

The water-extractable major cations in sediments from well 399-4-14 are tabulated in Table 5.40 in units of mass per gram of sediment on a dry weight basis. The dominant water-extractable cations in the sediments from well 399-4-14 were calcium and sodium. Interestingly, sodium concentrations were the same or higher than calcium concentrations in the water extracts, indicating that the sodium presence might be due to a contaminant waste source. The profile of sodium in these samples was different than nitrate, indicating that the two contaminants could be from different waste sources or that the sodium could be natural sodium leached or exchanged from the sediments. Unlike nitrate, there is still an indication of sodium contamination in the Ringold Formation because sodium was clearly the dominant waterextractable cation in the one sample analyzed from this subunit. In addition to sodium, the concentration of water-extractable potassium appears elevated in the Ringold Formation at this location. The concentration of water-exactable sodium in sample B1PL66-1 was similar to the concentrations measured in Ringold Formation sediments from well 399-3-22. Given the presence of elevated potassium in the Ringold Formation at wells 399-3-22 and 399-4-14, it appears that it is a result of contamination from a 300 Area process waste stream.

The 1:1 sediment:water-extractable aluminum, iron, sulfur, and phosphorus in sediments from well 399-4-14 are shown in Table 5.41. The sulfur and phosphorus data were converted to water-extractable sulfur as sulfate and phosphorus as phosphate so the results could be compared to the IC data shown in Table 5.39. The agreement between directly measured sulfate in the water extracts using IC and indirectly by converting the ICP measurements for sulfur to sulfate was excellent. Percent differences between the two data sets ranged from 0 to $8.4 \%$. In all cases except where the two values were equal, the IC-measured sulfate number was always greater than the ICP converted sulfur number. Neither 
analytical technique was able to detect phosphate in the water extract samples above the respective instrument's limit of quantification; thus, the two techniques could not be directly compared. The small amounts of water-soluble iron and aluminum that were detected intermittently in some of the samples analyzed from well 399-4-14 likely came from natural iron and aluminum bearing minerals present in the sediments.

Table 5.40. Water-Extractable Major Cations in Sediments from Well 399-4-14 ( $\mu \mathrm{g} / \mathrm{g}$ dry sediment) ${ }^{(\mathrm{a})}$

\begin{tabular}{lcccccc}
\hline $\begin{array}{c}\text { Sample Name } \\
(\text { HEIS ID) }\end{array}$ & $\begin{array}{c}\text { Sample } \\
\text { Mid Depth } \\
(\mathrm{ft} \text { bgs })\end{array}$ & $\begin{array}{c}\text { Calcium } \\
(\mu \mathrm{g} / \mathrm{g})\end{array}$ & $\begin{array}{c}\text { Potassium } \\
(\mu \mathrm{g} / \mathrm{g})\end{array}$ & $\begin{array}{c}\text { Magnesium } \\
(\mu \mathrm{g} / \mathrm{g})\end{array}$ & $\begin{array}{c}\text { Strontium } \\
(\mu \mathrm{g} / \mathrm{g})\end{array}$ & $\begin{array}{c}\text { Sodium } \\
(\mu \mathrm{g} / \mathrm{g})\end{array}$ \\
\hline B1PL64-2 & 36.5 & $1.99 \mathrm{E}+01$ & $4.30 \mathrm{E}+00$ & $3.51 \mathrm{E}+00$ & $9.02 \mathrm{E}-02$ & $2.11 \mathrm{E}+01$ \\
B1PL65-2 & 41.5 & $2.87 \mathrm{E}+01$ & $4.83 \mathrm{E}+00$ & $5.45 \mathrm{E}+00$ & $1.38 \mathrm{E}-01$ & $2.20 \mathrm{E}+01$ \\
C5707-43 & 43.0 & $2.23 \mathrm{E}+01$ & $5.18 \mathrm{E}+00$ & $4.51 \mathrm{E}+00$ & $1.17 \mathrm{E}-01$ & $1.99 \mathrm{E}+01$ \\
B1PL66-1 & 80.3 & $4.65 \mathrm{E}+00$ & $7.66 \mathrm{E}+00$ & $1.05 \mathrm{E}+00$ & $<1.50 \mathrm{E}-02$ & $1.07 \mathrm{E}+01$ \\
(a) < symbol indicates the analyte was below the detection limit. The minimum detection limit has been reported.
\end{tabular}

Table 5.41. Water-Extractable Cations in Sediments from Well 399-4-14 ( $\mu \mathrm{g} / \mathrm{g}$ dry sediment) ${ }^{(\mathrm{a})}$

\begin{tabular}{lccccc}
\hline $\begin{array}{c}\text { Sample Name } \\
(\text { HEIS ID) }\end{array}$ & $\begin{array}{c}\text { Sample } \\
\text { Mid Depth } \\
(\mathrm{ft} \text { bgs })\end{array}$ & $\begin{array}{c}\text { Aluminum } \\
(\mu \mathrm{g} / \mathrm{g})\end{array}$ & $\begin{array}{c}\text { Iron } \\
(\mu \mathrm{g} / \mathrm{g})\end{array}$ & $\begin{array}{c}\text { Sulfur } \\
\text { as } \mathrm{SO}_{4}{ }^{2-} \\
(\mu \mathrm{g} / \mathrm{g})\end{array}$ & $\begin{array}{c}\text { Phosphorus } \\
\text { a PO }_{4}{ }^{3-} \\
(\mu \mathrm{g} / \mathrm{g})\end{array}$ \\
\hline B1PL64-2 & 36.5 & $3.79 \mathrm{E}-02$ & $<3.00 \mathrm{E}-02$ & $1.76 \mathrm{E}+01$ & $<5.75 \mathrm{E}-01$ \\
B1PL65-2 & 41.5 & $<3.01 \mathrm{E}-02$ & $<3.01 \mathrm{E}-02$ & $1.95 \mathrm{E}+01$ & $<5.76 \mathrm{E}-01$ \\
C5707-43 & 43.0 & $3.47 \mathrm{E}-02$ & $<3.02 \mathrm{E}-02$ & $2.69 \mathrm{E}+01$ & $<1.16 \mathrm{E}+00$ \\
B1PL66-1 & 80.3 & $<3.00 \mathrm{E}-02$ & $3.27 \mathrm{E}-02$ & $3.07 \mathrm{E}+00$ & $<1.15 \mathrm{E}+00$ \\
\hline
\end{tabular}

(a) $<$ symbol indicates the analyte was below the detection limit. The minimum detection limit has been reported.

The water extract data for uranium-238 are shown in Table 5.42 and the results tabulated as a function of dry sediment weight in units of mass $(\mu \mathrm{g} / \mathrm{g})$. Although less emphasis was placed on the samples collected from well 399-4-14 than those from wells 399-2-5 and 399-3-22, two more samples and one duplicate sample were processed to determine their water-leachable uranium concentrations in addition to general inorganic constituents. All of the samples analyzed contained quantifiable concentrations of water-extractable uranium-238. Uranium is a naturally occurring element and as such is generally quantifiable in water extracts of any sediment analyzed (see dashed vertical line in Figure 5.8). In addition to natural uranium, several of the samples contained quantifiable concentrations of contaminant uranium. Like the two other wells, these sediments were retrieved within the lower vadose zone just and above the water table. While contaminant uranium is clearly present in sediments from this borehole, the peak concentration of $3.10 \mathrm{E}-02 \mu \mathrm{g} / \mathrm{g}$ is still relatively dilute. However, the peak water-extractable uranium concentration measured in vadose zone sediments from well 399-4-14 were the highest of the three wells analyzed in this study, including well 399-2-5 that was emplaced directly through the 316 SPP. This is surprising given that well 399-4-14 is far south of the 300 Area disposal facilities. Like those from well 399-2-5, the peak uranium-238 contaminated sediments found in well 399-3-22 reside in the lower vadose zone and just above the water table within the capillary fringe. These data further support the new conceptual model that, within the 300 Area, there is a rather dilute but extensive source of contaminant uranium in the deep vadose zone and capillary fringe sediments and their pore waters. 
Table 5.42. Water-Extractable Uranium in Sediments from Well 399-4-14

\begin{tabular}{lcc}
\hline $\begin{array}{c}\text { Sample Name } \\
(\text { HEIS ID) }\end{array}$ & $\begin{array}{c}\text { Sample Mid Depth } \\
(\mathrm{ft} b g s)\end{array}$ & $\begin{array}{c}\text { Uranium-238 } \\
(\mu \mathrm{g} / \mathrm{g})\end{array}$ \\
\hline B1PL64-4 & 34.5 & $3.10 \mathrm{E}-02$ \\
B1PL64-3 & 35.5 & $8.51 \mathrm{E}-03$ \\
B1PL64-2 & 36.5 & $5.77 \mathrm{E}-03$ \\
B1PL64-2 DUP & 36.5 & $6.07 \mathrm{E}-03$ \\
B1PL65-2 & 41.5 & $2.99 \mathrm{E}-02$ \\
C5707-43 & 43.0 & $1.49 \mathrm{E}-02$ \\
B1PL66-1 & 80.3 & $1.56 \mathrm{E}-03$ \\
\hline
\end{tabular}

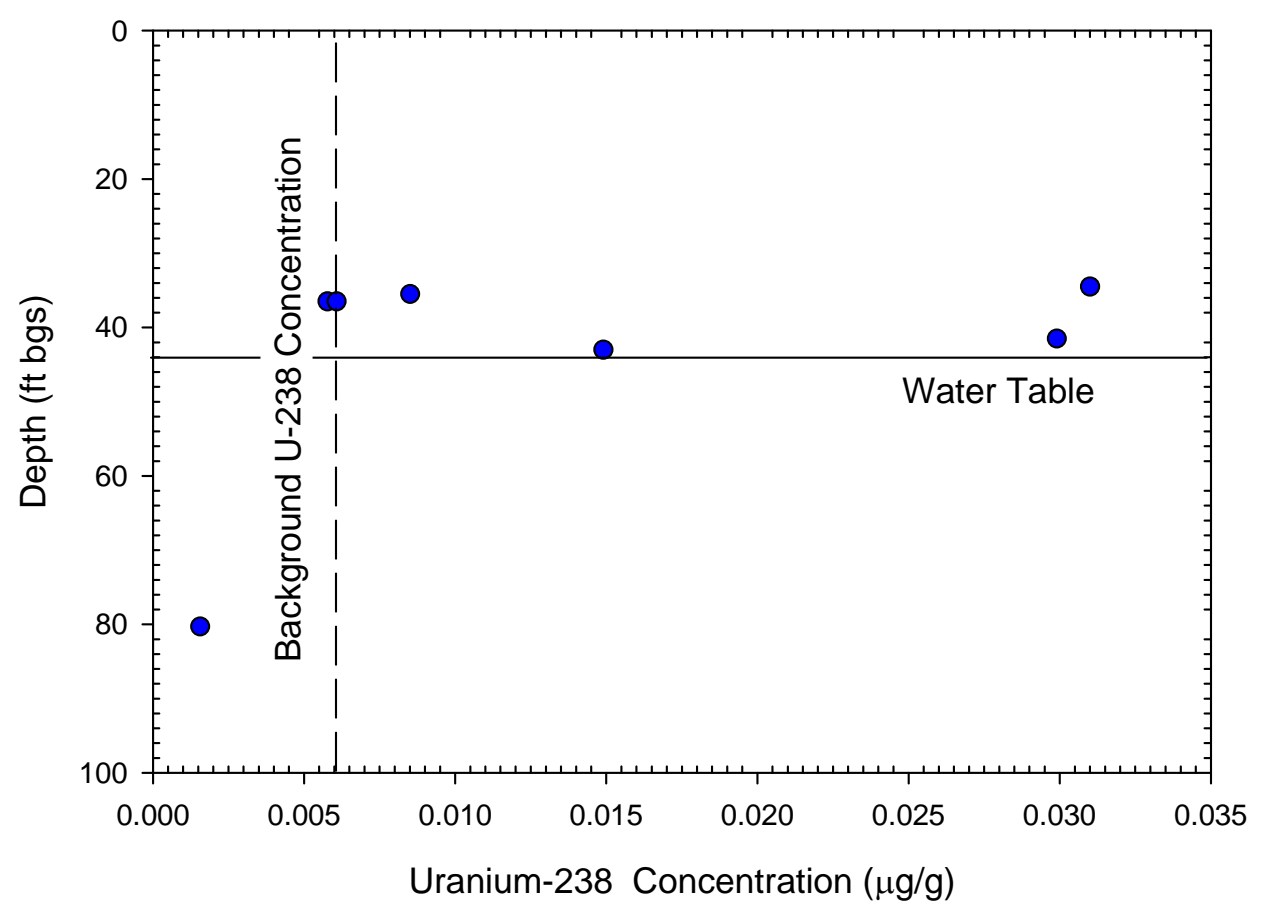

Figure 5.8. Concentration of Water-Extractable Uranium-238 in Sediments from Well 399-4-14

\subsubsection{Pore Water Chemical Composition}

The chemical composition of the residual pore water in sediments from well 399-4-14 was ascertained using the 1:1 sediment:water extract results presented in Section 5.3.2 in combination with the measured moisture contents of the field moist sediments (Section 5.3.1). The residual pore water was directly extracted using UFA. The extracted pore water was then analyzed without further dilution.

\subsubsection{Pore Water $\mathrm{pH}$ and Electrical Conductivity}

Table 5.43 contains the $\mathrm{pH}$ and EC data for UFA extracts of sediments from well 399-4-14. The range in measured $\mathrm{pH}$ values for the UFA extracts is similar but slightly narrower than that measured using the 1:1 sediment:water extraction technique, with a range of 7.66 to 8.30. Hanford sediments generally contain sufficient concentrations of carbonate-bearing minerals to mediate groundwater and pore water solutions in the $\mathrm{pH}$ range of 7.0 to 8.5 . 
Table 5.43. $\mathrm{pH}$ and EC Data in UFA Extracts of Sediments from Well 399-4-14

\begin{tabular}{cccc}
\hline $\begin{array}{c}\text { Sample Name } \\
\text { (HEIS ID) }\end{array}$ & $\begin{array}{c}\text { Sample Mid Depth } \\
(\mathrm{ft} b g s)\end{array}$ & $\mathrm{pH}$ & $\begin{array}{c}\mathrm{EC} \\
(\mathrm{mS} / \mathrm{cm})\end{array}$ \\
\hline B1PL64-4 UFA & 34.5 & 7.89 & $1.17 \mathrm{E}+00$ \\
B1PL64-3 UFA & 35.5 & 8.30 & $1.00 \mathrm{E}+00$ \\
B1PL65-2 UFA & 41.5 & 7.66 & $1.04 \mathrm{E}+00$ \\
B1PL66-1 UFA & 80.3 & 7.92 & $2.20 \mathrm{E}-01$ \\
\hline
\end{tabular}

Comparing the EC data in Table 5.43 with those generated via the 1:1 sediment:water extracts (Table 5.38) shows that the UFA extract EC data fall between the as-measured values in the 1:1 sediment:water extracts and the pore water-corrected values. In every case, the pore water-corrected EC data are approximately a factor of 3 higher than UFA extract results. This is the only set of data for which a systematic error appears to be present. The results imply that drying the samples and then extracting them using the 1:1 sediment:water technique has resulted in at least partial dissolution of the sediment.

\subsubsection{Major Anions and Cations}

Table 5.44 contains the major anions and Table 5.45 the major cations in UFA extracts as well as the corresponding pore water-corrected 1:1 sediment:water extract data for sediments from well 399-4-14. All data have been converted to units of meq/L so that charge balance comparisons (anions versus cations) could be made. Only two samples from well 399-4-14 contain complementary UFA and pore water-corrected sediment:water extract data, B1PL65-2 and B1PL66-1. Comparing the two sets of anion data in Table 5.44 indicates that there are significant differences in data generated by the two types of extracts. Both samples had approximately triple the dissolved anions in the 1:1 sediment:water extracts than in UFA extracts. For sample B1PL65-2, the water extract result had an order of magnitude higher alkalinity than the UFA extract of an aliquot of sediment from the same sample. While sediment heterogeneity can lead to differences in data generated via the two extraction techniques, it cannot be used to explain such a large discrepancy. Another factor that can affect the data is sediment moisture content. Sediment moisture content is important when water extract data are corrected to pore water concentration. Any drying of the sediment prior to analysis for moisture content can significantly affect the calculation. However, these sediments were controlled and kept refrigerated until processing (when their moisture content was measured), so it is unlikely that this could have caused the discrepancy. The most likely scenario is that the deionized water added to perform the 1:1 sediment:water extract dissolved carbonate coatings present on the sediments. The same seems likely for sample B1PL66-1, which had a pore watercorrected alkalinity of $6.20 \mathrm{meq} / \mathrm{L}$ versus $1.60 \mathrm{meq} / \mathrm{L}$ in the UFA extract. Of the three wells analyzed in this study, the discrepancies between the extracts of sediments from well 399-4-14 were the greatest.

The water and UFA-extractable cation data in Table 5.45 exhibit trends nearly identical to the anion results in Table 5.44. Both samples contained approximately 3 times more dissolved cations in the water extracts than in the UFA extracts. The dominant dissolved cation in sample B1PL65-2 was calcium; in sample B1PL66-1 it was sodium. Unlike the anion results, where a single anion comprised the majority of variability between the extracts, both sodium and calcium were variable in the water and UFA extracts. Sodium differed by approximately a factor of 4 and calcium by a factor of 3 in water and UFA extracts of sample B1PL65-2. For sample B1PL66-1, both elements were present in the water extract at approximately $2.5 \mathrm{x}$ their concentrations in the UFA extract. Based on these results, it appears that both calcium and sodium must be associated with the excess carbonate observed in the water extract samples. It is likely that calcium carbonate coatings on the sediments dissolve during the 1:1 sediment:water extraction. 
Table 5.44. Major Anions in UFA Extracts and Pore Water-Corrected 1:1 Sediment:Water Extracts of Sediments from Well 399-4-14 ${ }^{(\mathrm{a})}$

\begin{tabular}{lccccccc}
\hline $\begin{array}{c}\text { Sample Name } \\
\text { (HEIS ID) }\end{array}$ & $\begin{array}{c}\text { Sample } \\
\text { Mid Depth } \\
(\mathrm{ft} \text { bgs) }\end{array}$ & $\begin{array}{c}\text { Fluoride } \\
(\mathrm{meq} / \mathrm{L})\end{array}$ & $\begin{array}{l}\text { Chloride } \\
(\mathrm{meq} / \mathrm{L})\end{array}$ & $\begin{array}{c}\text { Nitrate } \\
(\mathrm{meq} / \mathrm{L})\end{array}$ & $\begin{array}{c}\text { Sulfate } \\
(\mathrm{meq} / \mathrm{L})\end{array}$ & $\begin{array}{c}\text { Phosphate } \\
(\mathrm{meq} / \mathrm{L})\end{array}$ & $\begin{array}{c}\text { Alkalinity } \\
\text { as CO }_{3} \\
(\mathrm{meq} / \mathrm{L})\end{array}$ \\
\hline \multicolumn{7}{c}{ Pore Water Corrected Water Extract Data } \\
\hline B1PL65-2 & 41.5 & $4.66 \mathrm{E}-01$ & $9.34 \mathrm{E}+00$ & $3.31 \mathrm{E}+00$ & $4.47 \mathrm{E}+00$ & $<5.16 \mathrm{E}-01$ & $1.54 \mathrm{E}+01$ \\
B1PL66-1 & 80.3 & $7.74 \mathrm{E}-02$ & $2.09 \mathrm{E}-01$ & $<9.40 \mathrm{E}-02$ & $4.05 \mathrm{E}-01$ & $<2.76 \mathrm{E}-01$ & $6.20 \mathrm{E}+00$ \\
\hline \multicolumn{7}{c}{ UFA Extract Data } \\
\hline B1PL65-2 UFA & 41.5 & $<1.05 \mathrm{E}-01$ & $5.19 \mathrm{E}+00$ & $2.37 \mathrm{E}+00$ & $1.81 \mathrm{E}+00$ & $<4.74 \mathrm{E}-01$ & $1.98 \mathrm{E}+00$ \\
B1PL66-1 UFA & 80.3 & $<1.05 \mathrm{E}-01$ & $2.45 \mathrm{E}-01$ & $<1.61 \mathrm{E}-01$ & $7.24 \mathrm{E}-01$ & $<4.74 \mathrm{E}-01$ & $1.60 \mathrm{E}+00$ \\
\hline (a) < symbol indicates the analyte was below the detection limit. The minimum detection limit has been reported.
\end{tabular}

Table 5.45. Major Cations in UFA Extracts and Pore Water Corrected 1:1 Sediment:Water Extracts of Sediments from Well 399-4-14

\begin{tabular}{ccccccc}
\hline $\begin{array}{c}\text { Sample Name } \\
\text { (HEIS ID) }\end{array}$ & $\begin{array}{c}\text { Sample } \\
\text { Mid Depth } \\
\text { (ft bgs) }\end{array}$ & $\begin{array}{c}\text { Calcium } \\
\text { (meq/L) }\end{array}$ & $\begin{array}{c}\text { Potassium } \\
\text { (meq/L) }\end{array}$ & $\begin{array}{c}\text { Magnesium } \\
\text { (meq/L) }\end{array}$ & $\begin{array}{c}\text { Strontium } \\
\text { (meq/L) }\end{array}$ & $\begin{array}{c}\text { Sodium } \\
\text { (meq/L) }\end{array}$ \\
\hline \multicolumn{7}{c}{ Pore Water Corrected Water Extract Data } \\
\hline B1PL65-2 & 41.5 & $1.56 \mathrm{E}+01$ & $1.34 \mathrm{E}+00$ & $4.87 \mathrm{E}+00$ & $3.43 \mathrm{E}-02$ & $1.04 \mathrm{E}+01$ \\
B1PL66-1 & 80.3 & $1.35 \mathrm{E}+00$ & $1.14 \mathrm{E}+00$ & $5.02 \mathrm{E}-01$ & $2.00 \mathrm{E}-03$ & $2.70 \mathrm{E}+00$ \\
\hline \multicolumn{7}{c}{ UFA Extract Data } \\
\hline B1PL65-2 UFA & 41.5 & $5.36 \mathrm{E}+00$ & $2.83 \mathrm{E}-02$ & $1.80 \mathrm{E}+00$ & $1.15 \mathrm{E}-02$ & $2.49 \mathrm{E}+00$ \\
B1PL66-1 UFA & 80.3 & 4.88E-01 & $2.18 \mathrm{E}-02$ & $1.66 \mathrm{E}-01$ & $1.48 \mathrm{E}-03$ & $1.05 \mathrm{E}+00$ \\
\hline
\end{tabular}

A review of the charge balance between anions and cations in the water and UFA extracts of samples from well 399-4-14 indicated that, similar to samples from wells 399-2-5 and 399-3-22, the samples were consistently overcharged with anions. The percent difference in charge balance ranged from 2.3 to $39 \%$, with an average difference of $19 \%$. The agreement in charge balance was slightly better for the water than for UFA extracts; the two water extracts exhibited charge balances of 2.6 and $19 \%$ versus 16 and $39 \%$ for the UFA samples. Because the differences in total charge between anions and cations were pervasive in both types of extracts, the differences can not be attributed to dissolution of host sediment during the 1:1 sediment:water extract. Instead, the differences may be due to an effect occurring during sample storage. Perhaps $\mathrm{CO}_{2}(\mathrm{~g})$ is dissolving into the pore water during storage of the samples, resulting in higher alkalinity results and contributing to an overbalance of anions in the water and UFA extracts.

Table 5.46 contains uranium-238 data from both water and UFA extracts. Because uranium-238 is the primary constituent of concern in this study, more data are available for it than any other constituent. Like the anion and cation data in Tables 5.44 and 5.45, the pore water-corrected uranium-238 values were considerably higher than UFA extract values; the pore water-corrected water extract data were 1.4 to 4.8 times higher than UFA data. This trend is contrary to that in samples from wells 399-2-5 and 399-3-22, in which UFA extracts generally contained more soluble uranium than pore water-corrected water extract data. The phenomenon in the samples from well 399-4-14 can be partially explained by examining the solution chemistry of the extracts. The water extract samples had much higher alkalinity than UFA extracts. At the nearly neutral to slightly basic $\mathrm{pH}$ of the extracts, alkalinity is expected to be almost entirely bicarbonate ion. Kalmykov and Choppin (2000) have shown the effect of bicarbonate on uranium solubility; higher bicarbonate concentrations lead to greater solubility of uranium. Thus the elevated uranium-238 in water versus UFA extracts is likely caused by the samples' elevated alkalinity. 
Table 5.46. Uranium Concentrations in UFA Extracts and Pore Water-Corrected 1:1 Sediment:Water Extracts of Sediments from Well 399-4-14

\begin{tabular}{ccc}
\hline $\begin{array}{c}\text { Sample Name } \\
(\text { HEIS ID) }\end{array}$ & $\begin{array}{c}\text { Sample Mid Depth } \\
(\mathrm{ft} b g s)\end{array}$ & $\begin{array}{c}\text { Uranium-238 } \\
(\mu \mathrm{g} / \mathrm{L})\end{array}$ \\
\hline \multicolumn{3}{c}{ Pore Water Corrected Water Extract Data } \\
\hline B1PL64-4 & 34.5 & $2.77 \mathrm{E}+02$ \\
B1PL64-3 & 35.5 & $1.03 \mathrm{E}+02$ \\
B1PL65-2 & 41.5 & $3.25 \mathrm{E}+02$ \\
B1PL66-1 & 80.3 & $9.09 \mathrm{E}+00$ \\
\hline \multicolumn{3}{c}{ UFA Extract Data } \\
\hline B1PL64-4 UFA & 34.5 & $5.84 \mathrm{E}+01$ \\
B1PL64-3 UFA & 35.5 & $7.53 \mathrm{E}+01$ \\
B1PL65-2 UFA & 41.5 & $6.78 \mathrm{E}+01$ \\
B1PL66-1 UFA & 80.3 & $3.09 \mathrm{E}+00$ \\
\hline
\end{tabular}

\subsection{4 $8 \mathrm{M}$ Nitric Acid-Extractable and Microwave-Assisted Digestible Concentrations of Uranium-238 in Sediments from Well 399-4-14}

Table 5.47 and Figure 5.9 contain the total acid-extractable and microwave-digestible uranium data (measured as $\mu \mathrm{g}$ uranium-238/g sediment on a dry weight basis) as a function of depth for four sediments collected from well 399-4-14. Acid-extractable uranium concentrations ranged from a low of $0.198 \mu \mathrm{g} / \mathrm{g}$ to a maximum of $1.34 \mu \mathrm{g} / \mathrm{g}$. The microwave digest method released more uranium from the sediments, 0.841 to $3.04 \mu \mathrm{g} / \mathrm{g}$. In every case, the microwave digests contained higher uranium concentrations; specifically, the microwave digests contained between 1.2 and 5.8 times more uranium than their companion acid extracts. All the microwave digests contained twice as much soluble uranium as their companion nitric acid extracts. This finding was not surprising because the microwave digest method results in complete sample dissolution, whereas the $8 \mathrm{M}$ nitric acid extract is less effective against recalcitrant minerals. The peak microwave-digestible uranium concentration measured in the sediments from well 399-4-14 was $3.04 \mu \mathrm{g} / \mathrm{g}$; peak concentrations were 3.65 and $5.50 \mu \mathrm{g} / \mathrm{g}$ in sediments from well 399-3-22 and 399-2-5, respectively. The peak uranium concentration in sediments from well 399-4-14 was found in a sample collected from the lower vadose zone (B1PL64-2). Sample coverage for well 399-4-14 was sparse due to prioritization of samples from the two other TCE wells. Although the data set is limited, the results from acid extraction and microwave digestion of sediments from well 399-4-14 are consistent with those from wells 399-2-5 and 399-3-22, in which there appears to be a large inventory of sediments containing rather dilute concentrations of contaminant uranium, with the majority of the contaminant uranium residing in the lower vadose zone and capillary fringe.

Table 5.47. Acid-Extractable (AE) and Microwave-Digestible (MD) Uranium in Sediments from Well 399-4-14

\begin{tabular}{cccc}
\hline $\begin{array}{c}\text { Sample Name } \\
(\text { HEIS ID) }\end{array}$ & $\begin{array}{c}\text { Sample Mid Depth } \\
(\mathrm{ft} b \mathrm{bs})\end{array}$ & $\begin{array}{c}\text { AE Uranium-238 } \\
(\mu \mathrm{g} / \mathrm{g})\end{array}$ & $\begin{array}{c}\text { MD Uranium-238 } \\
(\mu \mathrm{g} / \mathrm{g})\end{array}$ \\
\hline B1PL64-2 & 36.5 & $5.22 \mathrm{E}-01$ & $3.04 \mathrm{E}+00$ \\
B1PL65-2 & 41.5 & $1.34 \mathrm{E}+00$ & $1.55 \mathrm{E}+00$ \\
C5707-43 & 43.0 & $9.82 \mathrm{E}-01$ & $1.98 \mathrm{E}+00$ \\
B1PL66-1 & 80.3 & $1.98 \mathrm{E}-01$ & $8.41 \mathrm{E}-01$ \\
\hline
\end{tabular}




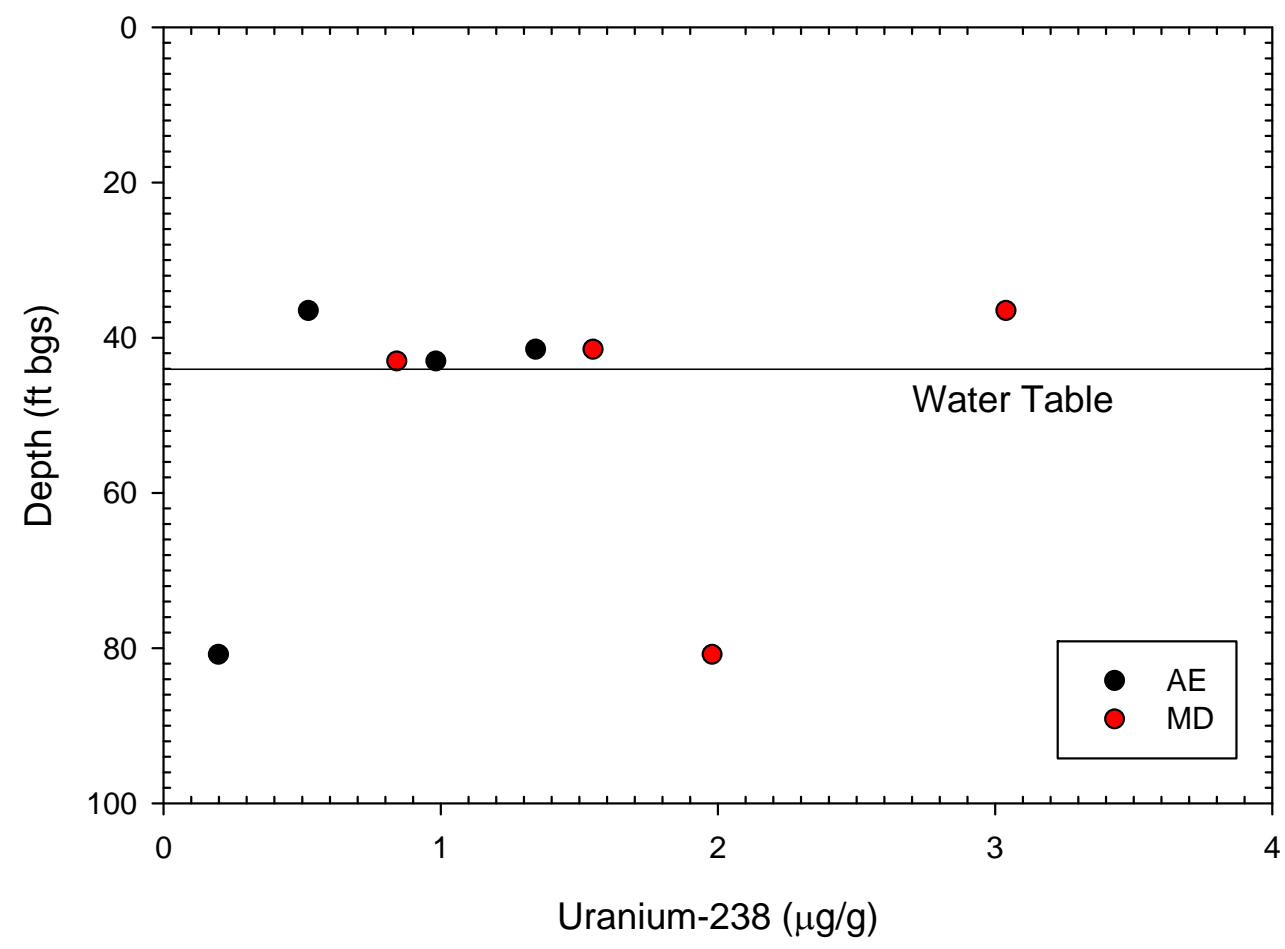

Figure 5.9. Concentration of Acid-Extractable (AE) and Microwave-Digestible (MD) Uranium-238 in Sediments from Well 399-4-14

A comparison of the water-extractable versus the acid-extractable and microwave-digestible uranium concentrations can be used to calculate an equilibrium $\mathrm{K}_{d}$ (partition coefficient) for uranium. An equilibrium $\mathrm{K}_{\mathrm{d}}$ can be used to estimate the relative leachability of uranium in the 300 Area sediments, assuming that the 1:1 sediment:water extract acted solely as a mechanism to remove the entrapped pore water from the sediments. Although these samples were air-dried before performing the 1:1 sediment: water extract, it is reasonable to assume that the extract would have efficiently dissolved the constituents that precipitated upon drying of the samples. The assumption that none of the solid is dissolved during the water extraction process is simplistic. Therefore, the equilibrium $\mathrm{K}_{\mathrm{d}}$ values presented in Table 5.48 based on the water extract results could be biased low (i.e., predicting greater release from the sediment).

The predicted equilibrium $\mathrm{K}_{\mathrm{d}}$ values presented in Table 5.48 vary considerably, ranging from 1.20 to $21.6 \mathrm{~mL} / \mathrm{g}$ using the acid extracts versus a range of 2.44 to $92.3 \mathrm{~mL} / \mathrm{g}$ using the microwave digests. The minimum reported $\mathrm{K}_{\mathrm{d}}$ values using both the acid and microwave digest data for well 399-4-14 were approximately an order of magnitude higher than those for well 399-2-5 and approximately an order of magnitude lower than those for well 399-3-22. According to these data (as with those from wells 399-2-5 and 399-3-22), the uranium contamination present in the sediments has a moderate to low tendency to release into deionized water such that many cycles of equilibrium concentrations can be generated (assuming all of the uranium in the pore water gets flushed out of the system) based on the existing inventory in the sediments. Like data from well 399-3-22, the sample with the lowest equilibrium $\mathrm{K}_{\mathrm{d}}$ value (i.e., highest potential to leach uranium) is the one just above the water table in the capillary fringe (C5707-43). 
Table 5.48. Equilibrium $K_{d}$ based on Water-Extractable (WE) Versus Acid-Extractable (AE) or Microwave-Digestible (MD) Uranium in Sediments from Well 399-4-14

\begin{tabular}{lccc}
\hline $\begin{array}{c}\text { Sample Name } \\
\text { (HEIS ID) }\end{array}$ & $\begin{array}{c}\text { Sample Mid Depth } \\
(\mathrm{ft} \text { bgs) }\end{array}$ & $\begin{array}{c}\text { Equilibrium } \mathrm{K}_{\mathrm{d}} \\
\text { based on WE and } \\
\text { AE Uranium-238 } \\
(\mathrm{mL} / \mathrm{g})\end{array}$ & $\begin{array}{c}\text { Equilibrium } \mathrm{K}_{\mathrm{d}} \\
\text { based on WE and } \\
\text { MD Uranium-238 } \\
(\mathrm{mL} / \mathrm{g})\end{array}$ \\
\hline B1PL64-2 & 36.5 & $9.97 \mathrm{E}+00$ & $5.86 \mathrm{E}+01$ \\
B1PL65-2 & 41.5 & $4.03 \mathrm{E}+00$ & $4.68 \mathrm{E}+00$ \\
C5707-43 & 43.0 & $1.20 \mathrm{E}+00$ & $2.44 \mathrm{E}+00$ \\
B1PL66-1 & 80.3 & $2.16 \mathrm{E}+01$ & $9.23 \mathrm{E}+01$ \\
\hline
\end{tabular}

\subsubsection{Labile Uranium Leach Test Results}

The concentration of labile (easily removable fraction, such as ion exchangeable or water soluble) uranium in the air-dried sediments was measured using a sodium bicarbonate/carbonate mixed solution $\left(1.44 \times 10^{-2} \mathrm{M}\right.$ in $\mathrm{NaHCO}_{3}$ and $2.8 \times 10^{-3} \mathrm{M}$ in $\left.\mathrm{Na}_{2} \mathrm{CO}_{3}\right)$. The amount of uranium leached from the sediments was determined as a function of time, with sampling after 1, 7, and 28 days of reaction. The goals of the time-dependent sampling are two: time-based sampling enables determining whether equilibrium (with respect to uranium solution concentrations) has been achieved in the reactors and allows general comments or conclusions about the rate of uranium release from the sediments. Table 5.49 and Figure 5.10 contain the data from the time-dependent labile uranium leach test; the data are reported as $\mu \mathrm{g}$ uranium leached per gram of sediment on a dry weight basis. Like the carbonate leach results from wells 399-2-5 and 399-3-22, the same two primary trends are evident in the data from well 399-4-14. The first trend involves a rather rapid release of uranium (approximately $85 \%$ of the total carbonate leachable fraction within the first seven days of reaction) from the sediment. The second can be characterized as a slow, continual release of uranium from the sediments. The kinetics of the second trend appears to extend beyond 28 days of reaction time because steady-state uranium solution concentrations were not achieved for any of the samples analyzed. The two trends evident as part of this experiment are likely the result of at least two types of uranium being present in the sediments. The first, which readily leaches upon contact with the carbonate/ bicarbonate solution, is likely present as an easily removable sorbed species. Conversely, the remaining uranium that can be characterized as having a very slow leach rate is likely present as discrete uranium-bearing minerals (Serne et al. 2002a) or as uranium microprecipitates that appear to be concentrated in fractures in feldspar crystals within granitic lithic fragments (Liu et al. 2004, 2006; McKinley et al. 2006). Uranium sorption onto or physical entrapment within nanocrystalline iron oxide coatings where uranium desorption is highly resistant can also be possible, as proposed by Bond et al. (2008).

Table 5.49. Labile Uranium Concentrations as a Function of Time in Sediments from Well 399-4-14

\begin{tabular}{ccccc}
\hline $\begin{array}{c}\text { Sample Name } \\
(\text { HEIS ID) }\end{array}$ & $\begin{array}{c}\text { Sample Mid Depth } \\
(\mathrm{ft} \text { bgs })\end{array}$ & $\begin{array}{c}\text { Labile Uranium } \\
\text { Time }=1 \text { Day } \\
(\mu \mathrm{g} / \mathrm{g})\end{array}$ & $\begin{array}{c}\text { Labile Uranium } \\
\text { Time }=7 \text { Days } \\
(\mu \mathrm{g} / \mathrm{g})\end{array}$ & $\begin{array}{c}\text { Labile Uranium } \\
\text { Time }=28 \text { Days } \\
(\mu \mathrm{g} / \mathrm{g})\end{array}$ \\
\hline B1PL64-2 & 36.5 & $6.12 \mathrm{E}-02$ & $9.15 \mathrm{E}-02$ & $1.03 \mathrm{E}-01$ \\
B1PL65-2 & 41.5 & $3.56 \mathrm{E}-01$ & $6.40 \mathrm{E}-01$ & $7.40 \mathrm{E}-01$ \\
C5707-43 & 43.0 & $2.62 \mathrm{E}-01$ & $4.05 \mathrm{E}-01$ & $4.68 \mathrm{E}-01$ \\
B1PL66-1 & 80.3 & $3.15 \mathrm{E}-02$ & $3.91 \mathrm{E}-02$ & $4.88 \mathrm{E}-02$ \\
\hline
\end{tabular}




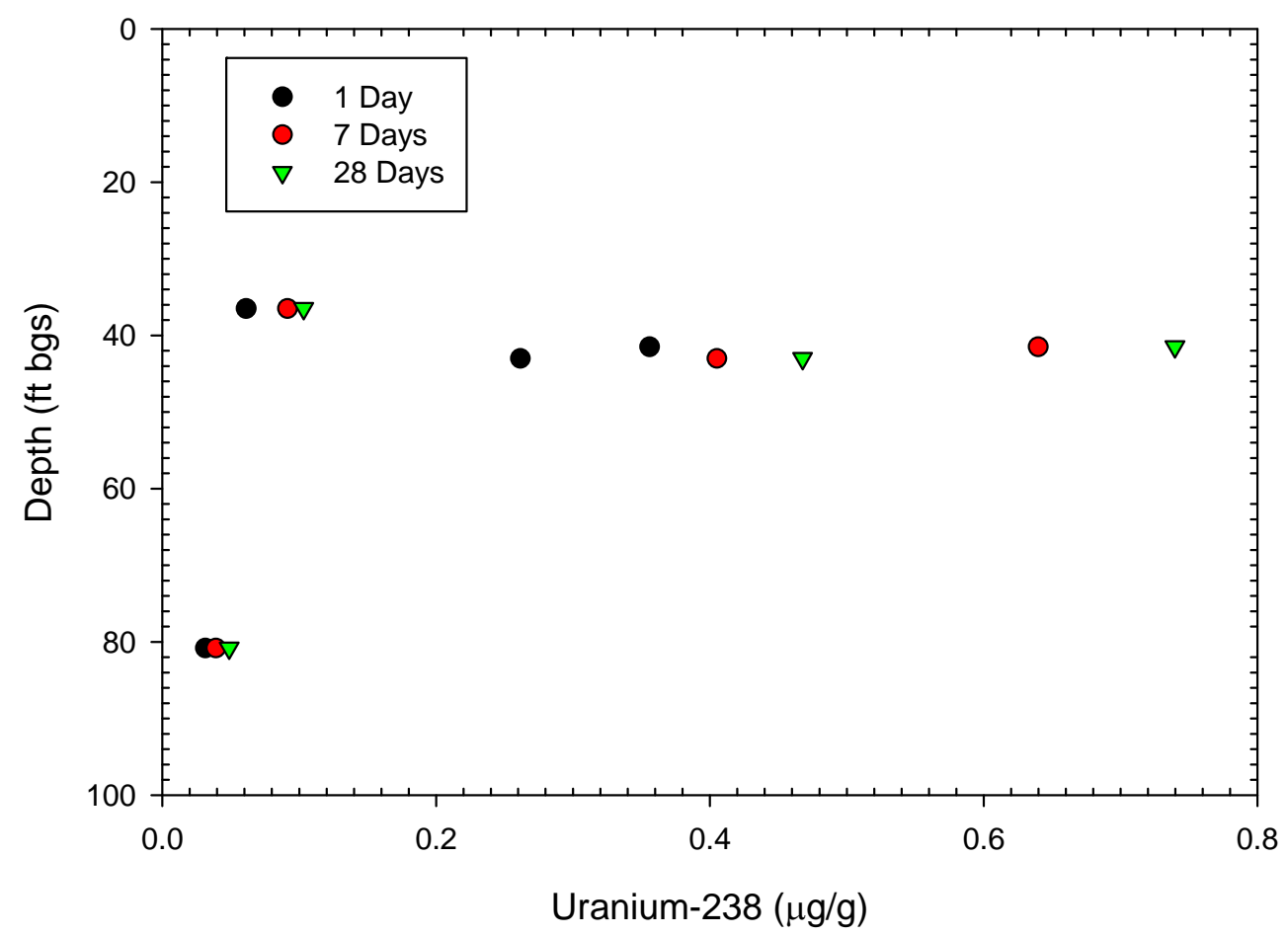

Figure 5.10. Concentration of Labile Uranium-238 in Sediments from Well 399-4-14

When the total amount of labile uranium (as measured during the 28 day sampling event) is used to calculate $\mathrm{K}_{\mathrm{d}}$ values, a considerably different picture becomes evident (Table 5.50). First, the calculated $\mathrm{K}_{\mathrm{d}}$ values are considerably lower than the acid-extractable and microwave-digestible data, ranging from 0.563 to $5.20 \mathrm{~mL} / \mathrm{g}$. For well 399-4-14, the sample with the highest amount of carbonate-leachable uranium (B1PL65-2) had the second-highest equilibrium $\mathrm{K}_{\mathrm{d}}(2.18 \mathrm{~mL} / \mathrm{g})$. This result implies that the inventory of uranium at the interface of the vadose zone and aquifer (i.e., the capillary fringe) has the potential to supply the aquifer with contaminant uranium for a substantial period of time.

Table 5.50. Equilibrium $\mathrm{K}_{\mathrm{d}}$ Based on Labile Uranium 28 Day Sample Versus Water-Extractable (WE) Uranium in Sediments from Well 399-4-14

\begin{tabular}{lcc}
\hline $\begin{array}{c}\text { Sample Name } \\
\text { (HEIS ID) }\end{array}$ & $\begin{array}{c}\text { Sample Mid } \\
\text { Depth } \\
(\mathrm{ft} \text { bgs })\end{array}$ & $\begin{array}{c}\text { Equilibrium } \mathrm{K}_{\mathrm{d}} \text { based on 28 Day } \\
\text { Sample and WE Uranium-238 } \\
(\mathrm{mL} / \mathrm{g})\end{array}$ \\
\hline B1PL64-2 & 36.5 & $1.88 \mathrm{E}+00$ \\
B1PL65-2 & 41.5 & $2.18 \mathrm{E}+00$ \\
C5707-43 & 43.0 & $5.63 \mathrm{E}-01$ \\
B1PL66-1 & 80.3 & $5.20 \mathrm{E}+00$ \\
\hline
\end{tabular}

\subsubsection{Total Carbon, Calcium Carbonate, and Organic Carbon Content of Sediment from Well 399-4-14}

Data from the total carbon, inorganic carbon, and organic carbon (calculated by difference) contents of the sediments collected during the drilling of well 399-4-14 are shown in Table 5.51. Inorganic carbon 
was only quantified in one of the samples from well 399-4-14; the estimated quantification limit for the non-reportable samples ranged from $9.11 \mathrm{E}-03$ to $2.97 \mathrm{E}-02 \mathrm{wt} \%$. Total carbon concentrations in the samples ranged from 3.36E-02 to 3.01E-01 wt\%. For the samples in which inorganic carbon was not detected above the limit of quantification, the signal measured as total carbon has been entirely attributed to organic carbon. The concentrations of organic carbon measured in these samples compare well with the two other TCE boreholes and those measured in boreholes C4999, C5000, C5001, and C5002, which all contained less than $1 \%$ organic carbon (Williams et al. 2007).

Table 5.51. Total, Inorganic, and Organic Carbon Content of Sediments from Well 399-4-14(a)

\begin{tabular}{lcccc}
\hline $\begin{array}{c}\text { Sample Name } \\
\text { (HEIS ID) }\end{array}$ & $\begin{array}{c}\text { Sample } \\
\text { Mid Depth } \\
(\mathrm{ft} \text { bgs })\end{array}$ & $\begin{array}{c}\text { Total } \\
\text { Carbon } \\
(\%)\end{array}$ & $\begin{array}{c}\text { Inorganic } \\
\text { Carbon } \\
(\%)\end{array}$ & $\begin{array}{c}\text { Organic } \\
\text { Carbon } \\
\text { (by difference) }\end{array}$ \\
\hline B1PL64-2 & 36.5 & $3.01 \mathrm{E}-01$ & $7.61 \mathrm{E}-02$ & $2.25 \mathrm{E}-01$ \\
B1PL65-2 & 41.5 & $1.10 \mathrm{E}-01$ & $<9.11 \mathrm{E}-03$ & $1.10 \mathrm{E}-01$ \\
C5707-43 & 43.0 & $3.36 \mathrm{E}-02$ & $<2.97 \mathrm{E}-02$ & $3.36 \mathrm{E}-02$ \\
B1PL66-1 & 80.3 & $3.58 \mathrm{E}-02$ & $<2.79 \mathrm{E}-02$ & $3.58 \mathrm{E}-02$ \\
\hline
\end{tabular}

(a) < symbol indicates the analyte was below the detection limit. The minimum detection limit has been reported.

\subsubsection{Analysis of Groundwater Samples from Well 399-4-14}

Groundwater samples analyzed by WSCF are presented in Tables 5.52 and 5.53 in units of meq/L to facilitate comparison with the UFA extract and 1:1 sediment:water pore water-corrected data presented earlier. The groundwater samples had an average dissolved anion content of $3.78 \mathrm{meq} / \mathrm{L}$. The primary anionic species in the groundwater samples was alkalinity (bicarbonate), with a range of 2.6 to $3.6 \mathrm{meq} / \mathrm{L}$. The remaining charge came from sulfate, chloride, and nitrate (note that the groundwater samples were analyzed for fewer elements than the water and UFA extract samples). The anionic charge in the groundwater samples was primarily balanced by calcium (average concentration of $1.88 \mathrm{meq} / \mathrm{L}$ ), with lesser amounts of sodium, magnesium, potassium, and strontium. Overall, the charge balance between anions and cations was quite good. The percent difference between dissolved anions and cations in the samples ranged from 0.04 to $12.0 \%$, indicating that while WSCF analyzed the groundwater samples for fewer anions, their analysis has captured the major constituents in the samples.

Table 5.52. Major Anions in Groundwater Samples from Well 399-4-14

\begin{tabular}{cccccc}
\hline $\begin{array}{c}\text { Sample Name } \\
\text { (HEIS ID) }\end{array}$ & $\begin{array}{c}\text { Sample } \\
\text { Mid Depth } \\
(\mathrm{ft} \text { bgs })\end{array}$ & $\begin{array}{c}\text { Chloride } \\
(\mathrm{meq} / \mathrm{L})\end{array}$ & $\begin{array}{c}\text { Nitrate } \\
(\mathrm{meq} / \mathrm{L})\end{array}$ & $\begin{array}{c}\text { Sulfate } \\
(\mathrm{meq} / \mathrm{L})\end{array}$ & $\begin{array}{c}\text { Alkalinity } \\
\text { as CO }_{3}{ }^{2-} \\
(\mathrm{meq} / \mathrm{L})\end{array}$ \\
\hline B1PLC0 & 49.8 & $4.85 \mathrm{E}-01$ & $8.23 \mathrm{E}-02$ & $8.50 \mathrm{E}-01$ & $2.60 \mathrm{E}+00$ \\
B1PLC1 & 59.0 & $5.07 \mathrm{E}-01$ & $8.35 \mathrm{E}-02$ & $9.17 \mathrm{E}-01$ & $2.60 \mathrm{E}+00$ \\
B1PLC2 & 68.5 & $4.96 \mathrm{E}-01$ & $8.03 \mathrm{E}-02$ & $8.83 \mathrm{E}-01$ & $2.60 \mathrm{E}+00$ \\
B1PLC3 & 78.0 & $3.52 \mathrm{E}-01$ & $4.05 \mathrm{E}-02$ & $4.65 \mathrm{E}-01$ & $2.80 \mathrm{E}+00$ \\
B1PLC4 & 83.0 & $1.83 \mathrm{E}-01$ & $1.61 \mathrm{E}-04$ & $7.19 \mathrm{E}-03$ & $3.20 \mathrm{E}+00$ \\
B1PLC5 & 92.8 & $1.99 \mathrm{E}-01$ & $8.06 \mathrm{E}-05$ & $1.19 \mathrm{E}-02$ & $3.20 \mathrm{E}+00$ \\
B1PLC6 & 109.8 & $2.49 \mathrm{E}-01$ & $5.48 \mathrm{E}-04$ & $3.33 \mathrm{E}-02$ & $3.40 \mathrm{E}+00$ \\
B1PLC7 & 125.8 & $2.90 \mathrm{E}-01$ & $1.77 \mathrm{E}-04$ & $2.60 \mathrm{E}-02$ & $3.60 \mathrm{E}+00$ \\
\hline
\end{tabular}


Table 5.53. Major Cations in Groundwater Samples from Well 399-4-14

\begin{tabular}{cccccc}
\hline $\begin{array}{c}\text { Sample Name } \\
\text { (HEIS ID) }\end{array}$ & $\begin{array}{c}\text { Sample } \\
\text { Mid Depth } \\
\text { (ft bgs) }\end{array}$ & $\begin{array}{c}\text { Calcium } \\
(\mathrm{meq} / \mathrm{L})\end{array}$ & $\begin{array}{c}\text { Potassium } \\
(\mathrm{meq} / \mathrm{L})\end{array}$ & $\begin{array}{c}\text { Magnesium } \\
(\mathrm{meq} / \mathrm{L})\end{array}$ & $\begin{array}{c}\text { Sodium } \\
(\mathrm{meq} / \mathrm{L})\end{array}$ \\
\hline B1PLC0 & 49.8 & $2.69 \mathrm{E}+00$ & $1.45 \mathrm{E}-01$ & $8.40 \mathrm{E}-01$ & $8.48 \mathrm{E}-01$ \\
B1PLC1 & 59.0 & $2.62 \mathrm{E}+00$ & $1.46 \mathrm{E}-01$ & $8.31 \mathrm{E}-01$ & $8.35 \mathrm{E}-01$ \\
B1PLC2 & 68.5 & $2.60 \mathrm{E}+00$ & $1.46 \mathrm{E}-01$ & $8.31 \mathrm{E}-01$ & $8.48 \mathrm{E}-01$ \\
B1PLC3 & 78.0 & $2.00 \mathrm{E}+00$ & $1.45 \mathrm{E}-01$ & $7.18 \mathrm{E}-01$ & $9.39 \mathrm{E}-01$ \\
B1PLC4 & 83.0 & $1.39 \mathrm{E}+00$ & $1.38 \mathrm{E}-01$ & $5.97 \mathrm{E}-01$ & $1.15 \mathrm{E}+00$ \\
B1PLC5 & 92.8 & $1.21 \mathrm{E}+00$ & $1.58 \mathrm{E}-01$ & $6.36 \mathrm{E}-01$ & $1.30 \mathrm{E}+00$ \\
B1PLC6 & 109.8 & $1.27 \mathrm{E}+00$ & $2.03 \mathrm{E}-01$ & $6.67 \mathrm{E}-01$ & $1.54 \mathrm{E}+00$ \\
B1PLC7 & 125.8 & $1.24 \mathrm{E}+00$ & $1.79 \mathrm{E}-01$ & $7.58 \mathrm{E}-01$ & $1.73 \mathrm{E}+00$ \\
\hline
\end{tabular}

Comparing the total concentration of anions and cations in the groundwater samples with those measured in water and UFA extracts showed that the groundwater sample was more dilute than the pore water-corrected water extract but more concentrated than the UFA extract. Sample B1PL66-1, which was collected within the Ringold Formation, was the only sample that could be used for this comparison because it was the only sample collected below the water table that was processed with both extraction techniques. Sample B1PL66-1 had a total dissolved salt load of $12.6 \mathrm{meq} / \mathrm{L}$ in the pore water-corrected water extract and $4.3 \mathrm{meq} / \mathrm{L}$ in the UFA extract, while groundwater sample B1PLC4 had a total dissolved salt load of $6.67 \mathrm{meq} / \mathrm{L}$. Although this is a single data point, the results imply that the water extraction of sediment results in an overestimation of the sediments pore water chemistry. Alkalinity was the anion with the largest discrepancy between the water and UFA extracts and groundwater samples. The alkalinity concentration in the groundwater sample was $3.2 \mathrm{meq} / \mathrm{L}$ and approximately 6.2 and $1.6 \mathrm{meq} / \mathrm{L}$ in the water and UFA extracts, respectively. Sodium and potassium were the corresponding cations, with the poorest agreement between the water extract and groundwater sample. Little consistency has been seen among the various extracts from the three TCE characterization wells. As shown, alkalinity was the primary anion that varied among the extracts and groundwater sample in well 399-4-14. In comparison, sulfate was in poorest agreement among the samples from wells 399-3-22 and 399-2-5. In well 399-4-14, alkalinity was grossly high in the pore water-corrected water extract, while alkalinity was higher in the groundwater sample from well 399-3-22 than in either of the extracts. These results indicate that an evaluation of multiple extraction techniques should be performed before using any one to estimate pore water solution concentrations.

The concentration of uranium-238 in the groundwater samples, as measured by WSCF, is reported in Table 5.54. The majority of the contaminant uranium in the aquifer resides in the gravel-dominated Hanford formation and the upper portion of the finer-grained Ringold Formation. The two samples collected within the upper $11 \mathrm{ft}$ of the Ringold Formation contained 46.3 and $24.4 \mu \mathrm{g} / \mathrm{L}$ uranium-238. These results were contrary to the groundwater data collected in the other two wells in the Ringold Formation, in which trace amounts $(<1 \mu \mathrm{g} / \mathrm{L})$ of uranium were found.

Of all the samples taken in the water and UFA extraction process, only one was retrieved from a depth similar to that where groundwater data are available (samples B1PL66-1). Comparison of these data with those generated via analysis of the groundwater sample identified that the UFA and water extract contained 20 and 60 times more uranium, respectively, than the nearest groundwater sample (B1PLC4). This trend is similar to that observed in samples from well 399-3-22 and implies that a more thorough investigation using additional laboratory extractions and analyses is warranted. 
Table 5.54. Uranium Concentrations in Groundwater Samples from Well 399-4-14

\begin{tabular}{ccc}
\hline $\begin{array}{c}\text { Sample Name } \\
(\text { HEIS ID) }\end{array}$ & $\begin{array}{c}\text { Sample Mid Depth } \\
(\mathrm{ft} b g s)\end{array}$ & $\begin{array}{c}\text { Uranium-238 } \\
(\mu \mathrm{g} / \mathrm{L})\end{array}$ \\
\hline B1PLC0 & 49.8 & $5.69 \mathrm{E}+01$ \\
B1PLC1 & 59.0 & $5.07 \mathrm{E}+01$ \\
B1PLC2 & 68.5 & $4.63 \mathrm{E}+01$ \\
B1PLC3 & 78.0 & $2.44 \mathrm{E}+01$ \\
B1PLC4 & 83.0 & $1.15 \mathrm{E}-01$ \\
B1PLC5 & 92.8 & $1.08 \mathrm{E}-01$ \\
B1PLC6 & 109.8 & $1.00 \mathrm{E}-01$ \\
B1PLC7 & 125.8 & $9.70 \mathrm{E}-02$ \\
\hline
\end{tabular}

\subsection{U(VI) Adsorption and Desorption for the LFI Well Sediments (Boreholes C4999 and C5000)}

\subsubsection{Sediment Characterization}

Two sediment cores, C4999-11D and C5000-39B, collected at depths near to the water table are classified as sandy gravel-dominated Hanford formation lithofacies (Williams et al. 2007). The sediments consist of gravels and cobbles mixed with sand and silt/clay, as seen in Figure 5.11. Particle size analyses after removal of the gravel $(>2-\mathrm{mm})$ fraction showed that sediment $11 \mathrm{D}$ consisted of sand $(53.4 \mathrm{wt} \%)$, silt (38.3 wt\%), and clay (8.27 wt\%), while sediment 39B consisted of sand (69.7 wt \%), silt (21.1 wt\%), and clay $(9.12 \mathrm{wt} \%)$, indicating both were sand-dominant with a similar clay fraction. Because the sediments were collected near the water table, the measured moisture contents $(9.73 \%$ and $13.8 \%$ for $11 \mathrm{D}$ and 39B, respectively) were higher than the moisture range found in the Hanford formation vadose zone sediment.
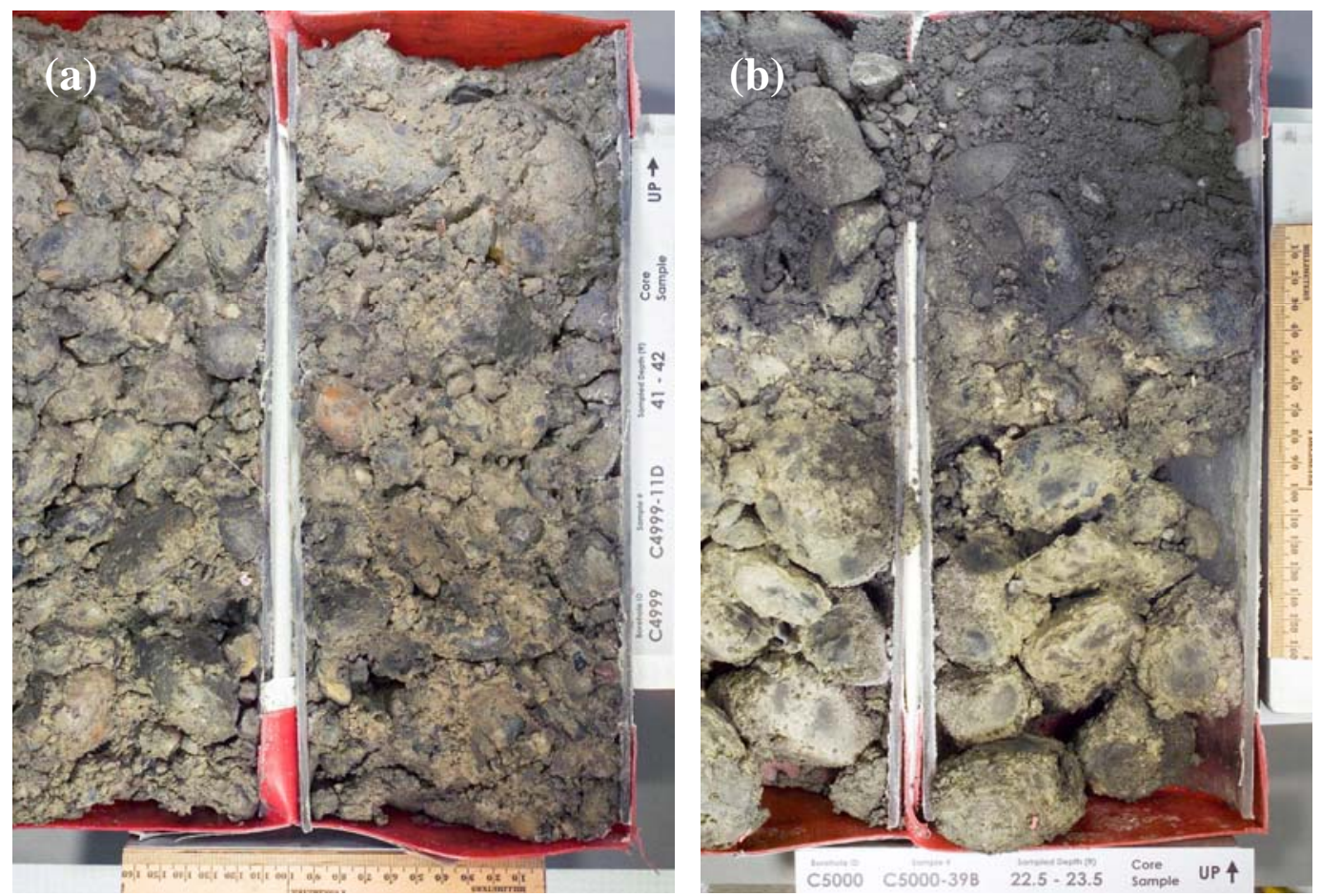

Figure 5.11. Core Photographs of (a) C4999-11D and (b) C5000-39B 
Higher inorganic carbon content was found in sediment 39B (3.42 $\mathrm{mg} / \mathrm{g}$ equivalent to $\left.2.85 \% \mathrm{CaCO}_{3}\right)$ than in sample 11D, which had no detectable inorganic carbon. Although other previous work showed that U-calcite coprecipitates were found in relatively shallow-depth sediments in the Hanford 300 Area (Catalano et al. 2006), no direct evidence for U-calcite coprecipitates was observed in the sediment from sample 39B because of the low total U(VI) concentration in the sediment. Even fluorescence spectroscopic measurements at near-liquid helium temperature did not show a discernable pattern between 480 and $580 \mathrm{~nm}$ indicative of U(VI). Other sediments containing low concentrations of contaminant U(VI) exhibited a clear fluorescence spectra (Wang et al. 2005); therefore, it was concluded that these sediments contain very low concentrations of hexavalent uranium.

\subsubsection{U(VI) Distribution of the Sediments}

Analyses of solutions produced by microwave-assisted strong acid digestion (MD) of sediments from boreholes C4999 and C5001 showed higher U(VI) concentrations in the deep vadose-zone sediments near the water table (Figure 5.12). These data indicate that the sediments in the capillary fringe close to the water table are a potential secondary source of U(VI) contamination that feeds the groundwater U(VI) plume. Concentrations of $\mathrm{U}(\mathrm{VI})$ in the sediments near the water table, ranging from 7 to $16 \mu \mathrm{g} / \mathrm{g}$ (Figure 5.12), are expected to leach enough U(VI) to elevate the U(VI) concentration in groundwater above the drinking water standard $(30 \mu \mathrm{g} / \mathrm{L})$ as the water table fluctuates with river stage. As the water table rises into the vadose zone sediments in the capillary fringe region, U(VI) desorption can be accelerated due to the increasing water contents (Zachara et al. 2005).

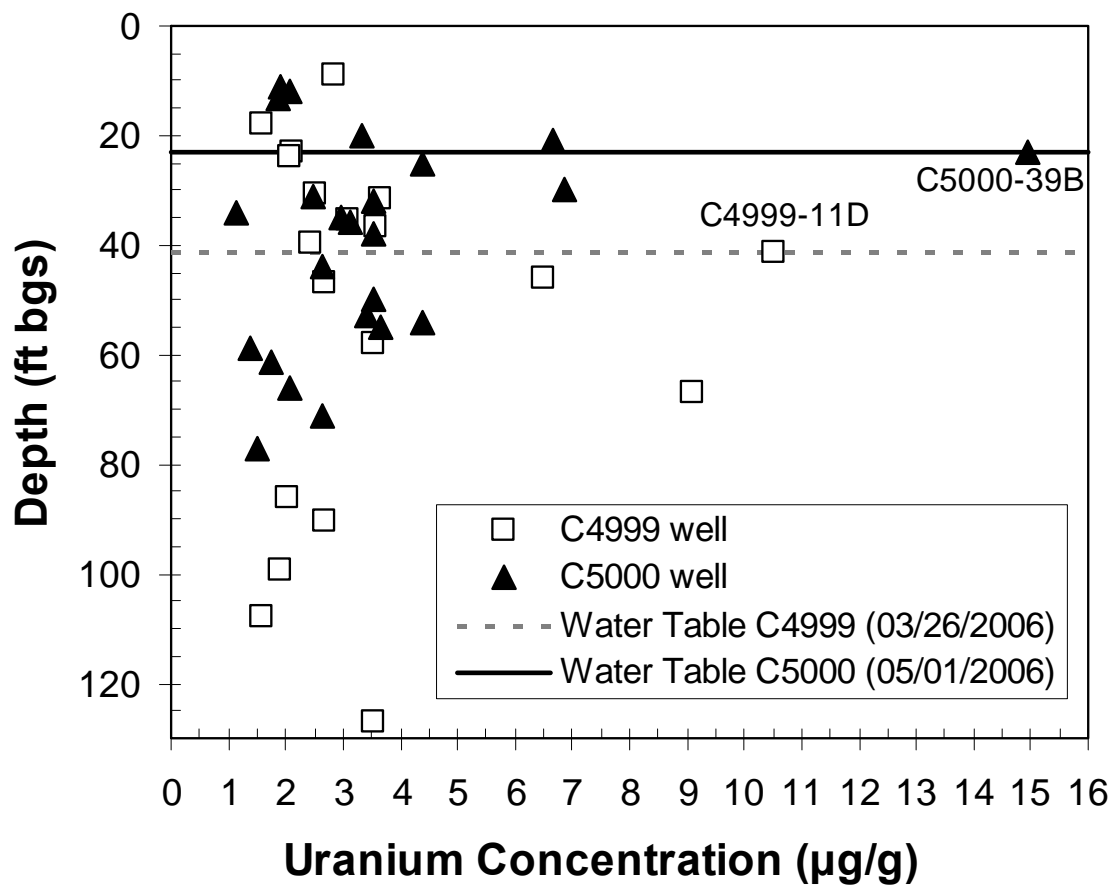

Figure 5.12. Distribution of Total U(VI) Concentration ( $\mu \mathrm{g} / \mathrm{g})$ in Sediments from C4999 and C5000 Wells as a Function of Depth 


\subsubsection{Labile U(VI) Concentrations by Bicarbonate Leaching}

Bicarbonate extraction, a measure of U(VI) lability (Kohler et al. 2004), displayed significant time dependence (Figure 5.13). The bicarbonate extraction of sediment 39B reached steady state after 10 days, yielding an estimated labile concentration of $6.5 \times 10^{-9} \mathrm{~mol} / \mathrm{g}\left(10 \%\right.$ of $\left.U_{\text {total }}\right)$. Sediment $11 \mathrm{D}$ released more $\mathrm{U}(\mathrm{VI})$ over a longer time period, showing a distinctive kinetic effect in spite of its lower total U(VI) concentration $\left(4.4 \times 10^{-8}\right.$ and $6.3 \times 10^{-8} \mathrm{~mol} / \mathrm{g}$ for $11 \mathrm{D}$ and $39 \mathrm{~B}$, respectively). The estimated labile U(VI) in $11 \mathrm{D}$ was $1.4 \times 10^{-8} \mathrm{~mol} / \mathrm{g}\left(32 \%\right.$ of $\left.\mathrm{U}_{\text {total }}\right)$. Measurement of $\mathrm{pH}(>9.0)$ and calcium concentrations that were input into saturation index calculation using Geochemist's Workbench confirmed that calcite precipitation did not occur during the bicarbonate extraction tests.

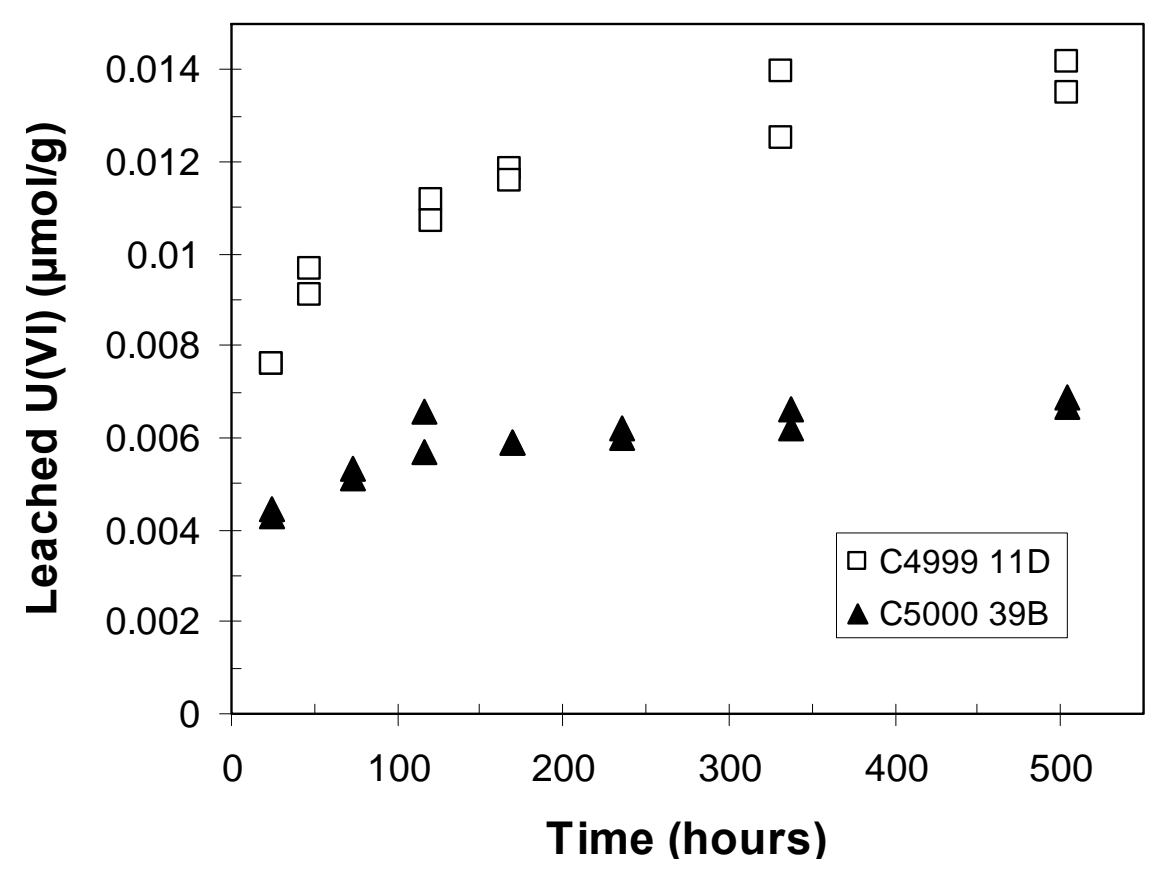

Figure 5.13. Labile U(VI) Concentration of Bicarbonate Extract for Sediment 11D and 39B

\subsubsection{U(VI) Adsorption Isotherm and Modeling}

The adsorption of spiked U(VI) on the washed sediments was consistently higher in sample 11D than in sample 39B (Figure 5.14). The lowest set of points for both sediments was influenced by desorption of residual contaminant $\mathrm{U}(\mathrm{VI})$. These were retained in the analysis and used for modeling. They generally align with the isotherm points resulting from spiked $\mathrm{U}(\mathrm{VI})$. The greater adsorption capacity of sample $11 \mathrm{D}$ for U(VI) was qualitatively consistent with its higher ammonium oxalate and DCB-extractable iron concentrations, surface area, and silt plus clay-size fractions ( $46.6 \%$ for $11 \mathrm{D} ; 30.2 \%$ for 39B). Distribution coefficients, $\mathrm{K}_{\mathrm{d}}(\mathrm{mL} / \mathrm{g})$, were calculated based on linear isotherm slopes passing through the origin (Figure 5.14). Sediment 39B showed good adherence to a linear isotherm $\left(R^{2}=0.94\right)$ with $K_{d}=3.23 \mathrm{~mL} / \mathrm{g}$, while 11D posed poor adherence to a linear isotherm $\left(R^{2}=0.54\right)$ and had a much higher $K_{d}(22.9 \mathrm{~mL} / \mathrm{g})$. In sample 11D, the amount of uranium sorbed onto the solid particles was independent of aqueous U(VI) concentrations (near-vertical line in Figure 5.14). These data indicate that something besides equilibrium partitioning is responsible for the distribution of uranium associated with the solid in this sample. 
The isotherms were used as the objective function to fit $\mathrm{U}(\mathrm{VI})$ surface complexation reaction constants for each sediment. A nonelectrostactic surface complexation model using a single monodentate $\mathrm{U}(\mathrm{VI})$ surface species, $\mathrm{SOUO}_{2} \mathrm{HCO}_{3}$, provided a good fit to the measured $\mathrm{U}(\mathrm{VI})$ adsorption isotherms with estimated $\log \mathrm{K}$ values of 17.2 and 16.6 for sediments $11 \mathrm{D}$ and $39 \mathrm{~B}$, respectively (Figure 5.14). The slightly negative adsorption described previously that resulted from contaminant U(VI) desorption at low aqueous $\mathrm{U}(\mathrm{VI})$ was included in the surface complexation analysis. The measured aqueous compositions of major cations at the adsorption equilibrium were used to compute major ion activities and U(VI) aqueous speciation.

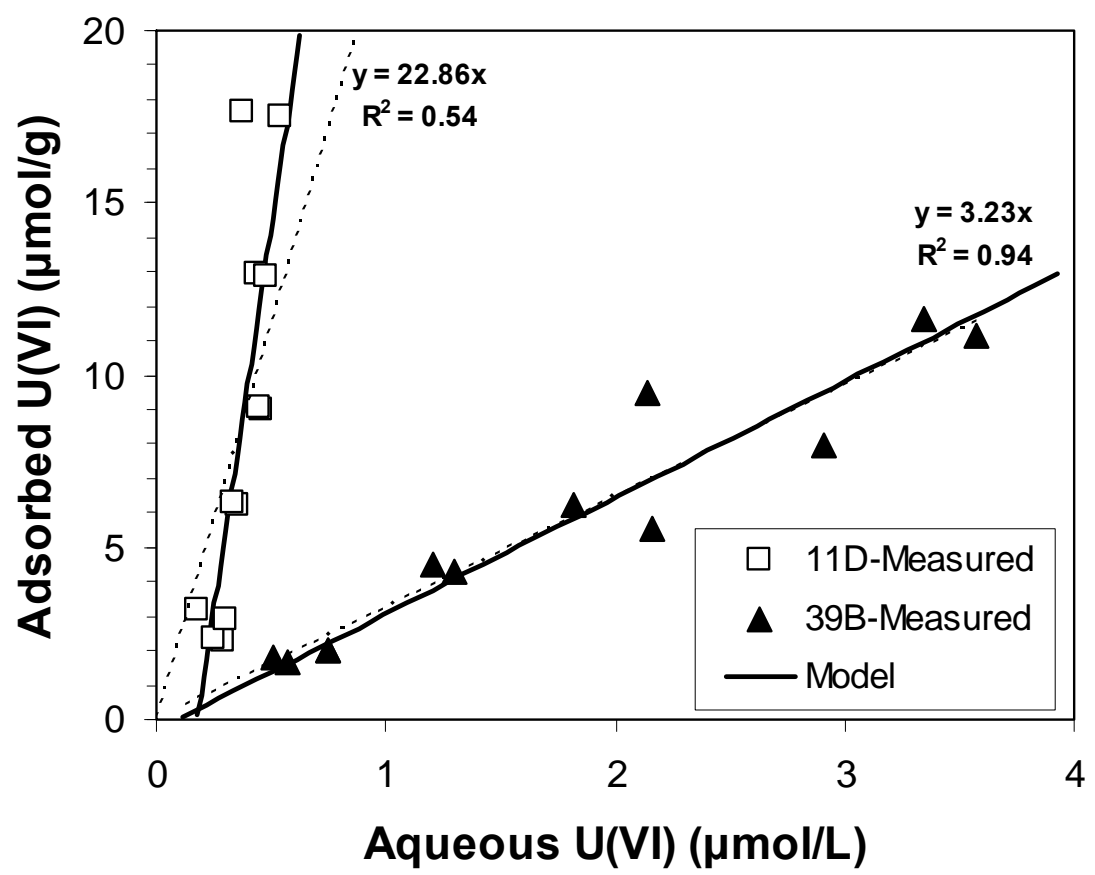

Figure 5.14. U(VI) Adsorption Isotherms for Two Sediments, Equilibrium Model Fits (solid lines), and a Linear Isotherm Passing Through the Origin with Correlation Coefficient $\left(\mathrm{R}^{2}\right)$ Value (dotted lines)

Studies (Catalano et al. 2006, Arai et al. 2007) have shown that metatorbernite $\left[\mathrm{Cu}\left(\mathrm{UO}_{2} \mathrm{PO}_{4}\right)_{2} \cdot 8 \mathrm{H}_{2} \mathrm{O}\right]$ and uranium silicates (uranophane and boltwoodite) were found at intermediate depths ( 3 to $12 \mathrm{ft}$ bgs) in sediments from below the 300 Area process ponds. However, because of the relatively lower total U(VI) concentrations in both sediments 11D and 39B from the LFI wells, and the relatively deeper depth from which samples 11D (41.5 ft bgs) and 39B (23.1 ft bgs) were collected compared to other NPP/SPP sediments (3-12 ft bgs) (Wang et al. 2005, Catalano et al. 2006, Arai et al. 2007), the most probable U(VI) phase on these sediments is adsorbed U(VI) on Fe oxides and/or aluminosilicates. In addition, 11D showed higher U(VI) adsorptive capacity than 39B, even though they have very similar mineralogy and total Fe oxide contents. The higher $\log \mathrm{K}$ value for sediment $11 \mathrm{D}$ implied that generic surface sites in $11 \mathrm{D}$ had a higher surface-area normalized capacity for U(VI) than the sorption sites in 39B. Bond et al. (2008) found similar variations in $\log \mathrm{K}$ for a different series of sediments collected nearby within the 300 Area NPP and SPP. Even though they used two reactions with addition of $\mathrm{SOUO}_{2} \mathrm{OH}$ to $\mathrm{SOUO}_{2} \mathrm{HCO}_{3}$, which was used in this study, the calculated $\log \mathrm{K}$ values for the $\mathrm{SOUO}_{2} \mathrm{HCO}_{3}$ surface complexation reaction on NPP and SPP sediments were 15.7 and 15.6, respectively, which are not significantly different 
from $\log \mathrm{K}$ values found in sample s11D (17.2) and 39B (16.6). However, as Dong et al. (2005) have shown, calcite tends to lower U(VI) adsorption on Hanford sediment by blocking access to more reactive surface adsorption sites; therefore, the relatively higher carbonate content in 39B than 11D (2.9 versus 0 $\mathrm{wt} \%$, respectively) might explain the lower U(VI) adsorption on 39B.

\subsubsection{U(VI) Desorption by Repetitive Washing and Modeling}

Two sediments were washed repeatedly using SGW-2-calcite solution prior to subjecting the sediments to isotherm measurements previously described. Remarkably different U(VI) desorption behavior was observed between sediments 11D and 39B (Figure 5.15). During washing, soluble and labile U(VI) was rapidly flushed from 39B to yield an aqueous concentration < MCL (30 ppb) of the five washings in 10 days. The release of U(VI) was slow and sustained from $11 \mathrm{D}$, requiring 36 separate electrolyte replacements to reach the MCL over 72 days. The total cumulative amount of U(VI) released by these washings was $2.1 \times 10^{-8}\left(48 \%\right.$ of $\left.U_{\text {total }}\right) \mathrm{mol} / \mathrm{g}$ in $11 \mathrm{D}$ after 72 days and $3.7 \times 10^{-9}\left(6 \%\right.$ of $\left.U_{\text {total }}\right) \mathrm{mol} / \mathrm{g}$ in $39 \mathrm{~B}$ after 10 days, respectively. These concentrations represented over $100 \%$ of bicarbonate extractable U(VI) for $11 \mathrm{D}$ and $57 \%$ of bicarbonate extractable U(VI) for 39B. Drying sediment $11 \mathrm{D}$ for approximately 500 hours led to a temporary increase in U(VI) desorption in the two subsequent washings. Beyond these two washings, the amount of U(VI) desorbed from $11 \mathrm{D}$ decreased to a remarkably consistent amount $\left(\sim 4 \times 10^{-}\right.$ ${ }^{11} \mathrm{~mol} / \mathrm{g}$ ) in each subsequent washing. These data yielded a constant negative linear slope in U(VI) concentration $(\mu \mathrm{mol} / \mathrm{L})$ in the wash solution versus time in later washing cycles (Figure 5.15).

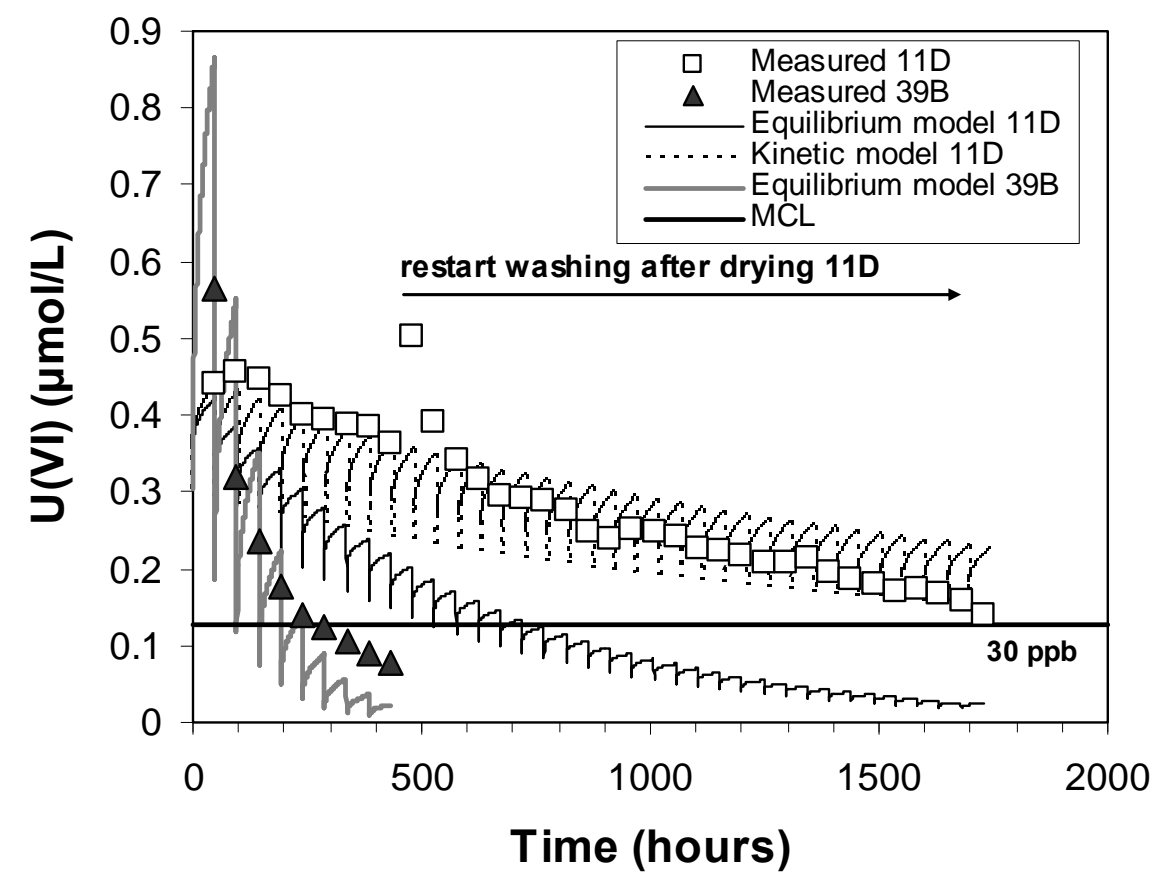

Figure 5.15. U(VI) Concentrations Desorbed by SGW-2-Calcite and Model Fits with Equilibrium and Kinetic Model for Sediment 11D and 39B 
The surface complexation model applied for U(VI) adsorption was also used to describe the U(VI) desorption in the sequential washing experiment (Figure 5.15). In each cycle of the multistep batch U(VI) desorption, the $\mathrm{pH}, \mathrm{Ca}$, and carbonate concentrations were measured and used for equilibrium modeling calculations along with the adsorption isotherm. The total labile U(VI) concentrations were decreased incrementally after each wash cycle in response to measured U(VI) concentration in the removed wash solution. The equilibrium model reasonably predicted $\mathrm{U}(\mathrm{VI})$ release in sediment 39B through multiple wash events, which supported the premise that U(VI) release from 39B obeyed the same equilibrium surface complexation reaction and constants as found for the previous isotherm experiment. The equilibrium surface complexation model, however, underpredicted U(VI) release from sediment 11D (Figure 5.15). The degree of underprediction increased with subsequent wash cycles. Mass balance calculations for the experimental data revealed that $2.1 \times 10^{-8} \mathrm{~mol} / \mathrm{g}$ of $\mathrm{U}(\mathrm{VI})$ was removed from $11 \mathrm{D}$ during the total sequential washing experiment, a value that was higher than the labile U(VI) $\left(1.4 \times 10^{-8}\right.$ $\mathrm{mol} / \mathrm{g}$ ) in $11 \mathrm{D}$ estimated from bicarbonate extraction but still lower than total U(VI) content of the sample $\left(4.4 \times 10^{-8} \mathrm{~mol} / \mathrm{g}\right)$. These findings indicated that the amount of labile U(VI) measured via the bicarbonate extraction tests was likely low. The addition of a kinetic component that allowed for labile U(VI) to increase with U(VI) release provided a better simulation of the sequential washing behavior of 11D (Figure 5.15). The kinetic resupply of labile U(VI) was described using a first-order kinetic model with an estimated rate constant of $2.8 \times 10^{-4} \mathrm{~h}^{-1}$.

Based on batch experiments, U(VI) desorption from two capillary fringe sediments (C4999-11D and C5000-39B) varied and were dependent on sediment properties and the chemical composition of the contacting solutions. The total U(VI) concentration was higher in sample $39 \mathrm{~B}\left(6.3 \times 10^{-8} \mu \mathrm{mol} / \mathrm{g}\right)$ than $11 \mathrm{D}\left(4.4 \times 10^{-8} \mu \mathrm{mol} / \mathrm{g}\right)$. However, $11 \mathrm{D}$ had a higher labile U(VI) concentration than $39 \mathrm{~B}$, consistent with results from the bicarbonate and repetitive extraction experiments. In particular, sample 11D had a higher desorbed U(VI) concentration as reaction time increased in both batch conditions.

Although $\mathrm{U}(\mathrm{VI})$ desorption from the two sediments from the capillary fringe was predicted well by the equilibrium surface complexation model, a kinetic resupply of U(VI) was required to better fit the measured U(VI) concentrations desorbed from 11D by repetitive washing, where the leaching solution was exchanged every 48 hours (Figure 5.15). The kinetic resupply was more noticeable as total reaction time increased after a subsequent 48-hour cycle. Because kinetics controlled the U(VI) desorption in $11 \mathrm{D}$, noticeably after a long reaction, more U(VI) can be released as longer times are allowed between draining and refilling cycles at the capillary fringe. The rate-limited mass transfer takes longer than the relatively instantaneous desorption of U(VI) from readily accessible surface sites.

The reason for the rate-limited mass transfer of U(VI) desorption in the Hanford 300 Area sediments was not clear. The continuously slow release of U(VI) from the lower vadose zone beneath the disposal sites is likely a result of residual uranium from the interaction between wastes plumes containing uranium and vadose zone sediment. Some fraction of uranium present in the waste plumes remained on the sediments as strongly bound phases, and the U(VI) is now available for subsequent remobilization by infiltrating water under high water table conditions. Another possibility can be found in the heterogeneity of 300 Area sediments with respect to particle characteristics and the capacity to transmit water. Fine grains (or lenses) of low-permeability sediment may have been saturated with the relatively more contaminated groundwater that existed during the operations period, and those fine-grained lenticular bodies are today slowly releasing contamination back into the relatively less-contaminated groundwater in the surrounding high-permeability sediment (Peterson et al. 2008a). Although this is speculative, it is certain that there is a more resistant U(VI) phase present on sample 11D compared to sediment 39B. Bond et al. (2008) have 
characterized this phase as U(VI) incorporated into nanocrystalline coatings. A more resistant U(VI) phase could be left in sample 11D rather than sample 39B, because 11D was collected in the deep vadose zone close to the Columbia River (borehole 399-3-18 in Figure 1.1). Sample 11D has had frequent contact with relatively dilute groundwater that mixed with infiltrating river water, potentially removing the mostly unstable U(VI) phase during these washing cycles. However, because sediment 39B was collected at a relatively shallow depth far from the river shore, it has not had a history of extensive contact with the episodically fluctuating groundwater. Therefore, sample 39B likely still retains more easily leachable U(VI) than sample 11D. 



\subsection{Summary and Conclusions}

The primary objectives of this characterization activity were to 1) determine the extent of uranium contamination in the sediments retrieved during drilling of the VOC boreholes, 2) quantify the leachable (labile) concentration of uranium in the sediments, and 3) create a data set that could be used to correlate the present data to existing 300 Area data. To meet these objectives, sediment $<2 \mathrm{~mm}$ in diameter collected from wells 399-2-5 (C5708), 399-3-22 (C5706) and 399-4-14 (C5707) was analyzed for moisture content, 1:1 sediment:water extracts (which provide soil $\mathrm{pH}, \mathrm{EC}$, cation, anion, and uranium data), total carbon and inorganic carbon content, $8 \mathrm{M}$ nitric acid extracts (which provide a measure of the total leachable sediment content of contaminants and major constituents), microwave-assisted digestion (which results in total digestion of the sediment), and carbonate leaches (which provide an assessment of the concentration of labile uranium present in the sediments). Additionally, pore waters present in select samples were extracted using UFA. This section summarizes the findings of these characterization activities and includes conclusions based on interpretation of the data from these studies as well as reinterpretation of results from other 300 Area characterization campaigns.

- The five most dominant hydrogeologic units encountered during drilling of the VOC boreholes (listed from youngest to oldest) include anthropogenically reworked surface sediments, Hanford formation coarse gravel, Ringold Formation undesignated finer-grained lithologies, Ringold Formation coarse gravel, and Ringold Formation mud/silt.

- The unconfined aquifer within the 300 Area groundwater system extends from the Hanford formation through the Ringold Formation to the lower mud unit that acts as a confining layer between the unconfined aquifer system and the basalt confined aquifer system. Within the unconfined aquifer, the Hanford formation and Ringold Formation exhibit drastically different permeabilities. The Hanford formation gravels are very transmissive and tend to contain the bulk of the uranium contaminated groundwater (ranges of 12 to $70 \mu \mathrm{g} / \mathrm{L}$ in the three VOC boreholes). Conversely, the finer-grained sediment of the Ringold Formation is much less permeable and contains trace (less than $0.05 \mu \mathrm{g} / \mathrm{L}$ ) to moderate $(46 \mu \mathrm{g} / \mathrm{L})$ amounts of uranium at the three locations interrogated by these boreholes. (Note: the uranium concentration of $46 \mu \mathrm{g} / \mathrm{L}$ in the Ringold Formation was measured in a sample collected just below the interface of the Ringold and Hanford formations and likely has been influenced by water drawn from the more permeable Hanford formation, which contained 50 to $57 \mu \mathrm{g} / \mathrm{L}$ dissolved uranium).

- Measured moisture content within the vadose zone sediments (comprised entirely of Hanford formation sediments) was variable but correlated well with sample lithology. Several samples containing significant amounts of moisture (12 to $30 \mathrm{wt} \%$ ) were encountered during the drilling of wells 399-2-5 and 399-3-14. These results show that while the Hanford formation is primarily composed of coarse sand and gravel, it does contain lenses of fine-grained sediment.

- Analysis of the 1:1 sediment:water extract samples for $\mathrm{pH}$ and EC identified that all three boreholes were composed of sediments exhibiting standard soil $\mathrm{pHs}$ (the typical $\mathrm{pH}$ range for Hanford and Ringold formation sediments is between 7 and 8.5). Additionally, as-measured and pore watercorrected ECs of the water extract samples indicated that the 300 Area sediments contained low to moderate concentrations of dissolved anions and cations. Excluding the one high EC value (sample B1PL49-1), sediments from well 399-2-5 had pore water-corrected conductivities between 0.437 and $10.1 \mathrm{mS} / \mathrm{cm}$. Sediments from well 399-3-22 had pore water-corrected conductivities ranging from 
0.184 to $4.08 \mathrm{mS} / \mathrm{cm}$. Finally, excluding the one sample with very low moisture content (C5707-43), sediments from well 399-4-14 had pore water-corrected conductivities between 0.664 and $3.53 \mathrm{mS} / \mathrm{cm}$.

- Sediments collected within the vadose zone from well 399-2-5 clearly contained nitrate contamination. The peak water-extractable nitrate concentration of $36.3 \mu \mathrm{g} / \mathrm{g}$ was approximately 7.5 times higher than the concentration measured by Serne et al. (2002a) in background 300 Area sediments.

- The dominant anions in water and UFA extracts fluctuated between sulfate and alkalinity (bicarbonate). The negative charge from dissolved anions was typically balanced by calcium and/or sodium in the 1:1 water and UFA extracts. Typically calcium is present as the dominant extractable cation in uncontaminated Hanford formation and Ringold Formation sediments. However, in some instances, the concentration of water and UFA extractable sodium exceeded that of calcium, which indicated that the chemistry of the sediment could have been affected by a 300 Area waste stream. This trend was particularly evident in the vadose zone sediments collected from well 399-3-22, which had an average water extractable sodium concentration of $19.5 \mu \mathrm{g} / \mathrm{g}$ versus $7.78 \mu \mathrm{g} / \mathrm{g}$ for calcium.

- Evaluation of water- versus UFA-extractable total anions versus total cations did not result in any clear trends. In some cases, the two extracts agreed well (e.g., samples C5708-56.5 and B1PL48-1 from well 399-2-5), but in some instances the two extracts varied by more than a factor of 3 (e.g., samples B1PL65-2 and B1PL66-1 from well 399-4-14). In most cases in which there was variability between the two types of extractions, the pore water-corrected data exhibited higher concentrations of anions and cations than the UFA extract data. While this finding is unfortunate (water extracts are easier to perform than UFA extracts), it was not entirely unexpected. In comparisons of actual vadose zone pore water (obtained through UFA of sediments) and dilutioncorrected pore water the latter exhibited more concentrated chemistries by a factor of 2 to 7 (e.g., Serne et al. 2002b, 2002c, 2002d, 2002e, 2002f) in slightly contaminated or uncontaminated sediments. In many cases, this means that the true pore water was less saline.

- Comparison of the major anions and cations in the groundwater samples with those for which comparable sediment extracts were available uncovered mixed results. In some instances, both extracts resulted in more saline solutions than the actual groundwater (e.g., samples analyzed from well 399-2-5). In other instances, the UFA extracts contained the least saline solutions, followed by the groundwater and the water extracts (e.g., samples from well 399-4-14). In well 399-3-22 the results were more variable. Within the Hanford formation, the UFA extracts were the least saline, followed by the groundwater samples and the water extracts. Conversely, in the Ringold Formation, the groundwater samples were the least saline, followed by the water extracts and UFA extracts. It is difficult to ascertain the reason for the variability among the three datasets. While it does appear that the concentrations in water extracts were elevated due to partial dissolution of the host sediment (e.g., calcite coatings), they were not always more concentrated than the UFA extracts, and in some cases agreed well with the UFA extract and groundwater data. Conversely, the chemistries of the UFA extracts should have been in close agreement with those of the groundwater samples because it was residual groundwater that was extracted from the sediments during the centrifugation process. However, in some sample sets, the UFA extracts were the most dilute, while in another sample set they were the most saline. It is unclear whether sample processing or storage could have affected the chemistries of the water and UFA extracts (perhaps atmospheric $\mathrm{CO}_{2}$ dissolved into the pore fluids during sample storage, increasing the alkalinity of the sample). While a direct cause of the 
inconsistency in datasets cannot be identified, it is clear that a combination of extraction techniques should be evaluated before assigning a specific pore water solution chemistry to the samples.

- Concentrations of water-extractable uranium were quite dilute in sediments from all three of the TCE wells. It was surprising that the sediments collected farthest from the known 300 Area waste sites contained the highest concentrations of water-extractable uranium (3.10E-02 $\mu \mathrm{g} / \mathrm{g}$ in sample B1PL64-4 from well 399-4-14). A similar profile of contaminant uranium was evident in all three boreholes. In all cases, the peak concentrations of water-extractable uranium were found in the deep vadose zone and capillary fringe. This is particularly problematic because it is exactly this region of the subsurface that is affected during fluctuations in river stage elevation. During times of high river stage, river water infiltrates into the vadose zone beneath the 300 Area and serves to raise the elevation of the water table. The elevated water table will come into contact with the contaminant uranium and leach some portion of it from the sediments, thereby replenishing the current groundwater plume underlying the 300 Area. If sufficient river water has infiltrated to cause a change in geochemical conditions, it is also possible that the concentration of uranium in the groundwater would be lowered by simple dilution.

- Results from the acid extracts and microwave digestions of sediments from all three of the TCE wells indicated that the total concentrations of uranium in the boreholes were relatively low. The peak microwave-digestible uranium concentrations ranged from $3.04 \mu \mathrm{g} / \mathrm{g}$ in well 399-4-14 to $5.50 \mu \mathrm{g} / \mathrm{g}$ in well 399-2-5. This result was particularly surprising because well 399-2-5 (which was emplaced directly through the 316 SPP) was expected to contain significant quantities of contaminant uranium. Like the water extract data, the peak acid-extractable and microwave-digestible uranium was always encountered in sediments collected within the deeper vadose zone and capillary fringe. The overall low concentrations of total uranium in these samples call into question the box model reported by Peterson et al. (2008a) that attributed a large portion of uranium inventory to the vadose zone directly beneath known disposal facilities. Instead, it appears there is a rather dilute but extensive source of contaminant uranium residing just above the water table throughout much of the 300 Area.

- Apparent $\mathrm{K}_{\mathrm{d}}$ values, calculated using the 1:1 sediment:water extract and acid digest or microwave extract data, were variable and indicated that the contaminant uranium could be classified as mobile $\left(\mathrm{K}_{\mathrm{d}}\right.$ value less than $\left.1 \mathrm{~mL} / \mathrm{g}\right)$ to very immobile $\left(\mathrm{K}_{\mathrm{d}}\right.$ values greater than $\left.100 \mathrm{~mL} / \mathrm{g}\right)$. Not only were there differences among samples collected from the three TCE wells, there were observed differences between samples collected within a single well. For example, some of the highest calculated $\mathrm{K}_{\mathrm{d}}$ values were for the samples collected near or just above the water table. Specifically, sample B1PL49-1 (from well 399-2-5) had a $\mathrm{K}_{\mathrm{d}}$ of $194 \mathrm{~mL} / \mathrm{g}$ based on the acid extract uranium data and 455 $\mathrm{mL} / \mathrm{g}$ based on the microwave digest uranium data. Similarly, sample B1PL57-2 (from well 399-322) had a $\mathrm{K}_{\mathrm{d}}$ of $1670 \mathrm{~mL} / \mathrm{g}$ based on the acid extract uranium data and $3730 \mathrm{~mL} / \mathrm{g}$ based on the microwave digestion uranium data. Although both of these samples had the highest measured total uranium concentrations within their respective boreholes, they also had some of the highest calculated $\mathrm{K}_{\mathrm{d}}$ values. This is particularly important because the depths from which these samples were collected are most susceptible to changes in water table elevation. As the water table rises and falls, these sediments go through repeated wetting and drying cycles. As the sediments become hydraulically saturated, some of the uranium contained in them will slowly leach into the groundwater, providing a long-term source of uranium to the aquifer.

- Within well 399-2-5, the lowest calculated $\mathrm{K}_{\mathrm{d}}$ based on the acid extract and microwave digest data was collected just below the water table (B1PL50-2). The sample collected from approximately $35 \mathrm{ft}$ 
bgs had a $\mathrm{K}_{\mathrm{d}}$ of $0.269 \mathrm{~mL} / \mathrm{g}$ based on the acid extract data and $0.847 \mathrm{~mL} / \mathrm{g}$ based on the microwave digest data. A similar trend was observed in data from well 399-4-14; sufficient sampling was not performed near the water table to assess this feature in well 399-3-22. Cumulatively, these data imply that the uranium contamination residing below the top of the water table is fairly mobile and remains in solution as the groundwater migrates throughout the 300 Area.

- The labile uranium batch leach tests revealed two primary trends. The first involved a rather rapid release of uranium from the sediment. This initial release occurred within the first seven days of reaction and accounted for approximately $85 \%$ of the total amount of uranium removed from the sediments. The second trend can be characterized as a slow, continual release of uranium from the sediments. The kinetics of this trend extended beyond 28 days of reaction time; steady-state uranium solution concentrations were not achieved for any of the samples analyzed. The two trends evident in these experiments are likely the result of two types of uranium being present ion the sediments. The first type of uranium, which readily leaches upon contact with the carbonate/bicarbonate solution, is likely present as an easily removable sorbed species. Conversely, the remaining uranium, characterized by a very slow leach rate, is likely present as discrete uranium-bearing minerals (Serne et al. 2002a) or as uranium microprecipitates that appear to be concentrated in fractures in feldspar crystals within granitic lithic fragments (Liu et al. 2004, 2006; McKinley et al. 2006). Additionally, uranium sorption onto or physical entrapment within nanocrystalline iron oxide coatings where uranium desorption is highly resistant can be also possible, as proposed by Bond et al. (2008).

- When the total amount of labile uranium (as measured in the 28 day sampling event) was used to calculate $K_{d}$ values, the $K_{d}$ values were considerably lower than those calculated using the acid extract or microwave digest data. With the exception of sample B1PL48-1, all of the vadose zone sediment samples had $\mathrm{K}_{\mathrm{d}}$ values between 0.1 and $5 \mathrm{~mL} / \mathrm{g}$, much more consistent with values reported by other researchers that have characterized similar sediments (Serne et al. 2002a, Zachara et al. 2005, Williams et al. 2007). One surprising data point using this technique was for sample B1PL54-1, which had an equilibrium $\mathrm{K}_{d}$ value of $1.98 \mathrm{~mL} / \mathrm{g}$. Sample B1PL54-1 was collected well below the water table and within the Ringold Formation in well 399-2-5, so it was not expected to contain much mobile uranium. Because carbonate leach data have been used to generate these $\mathrm{K}_{\mathrm{d}}$ values, the total uranium concentration is actually the total amount of uranium available for leaching (assuming the carbonate leach test removes only leachable uranium). Even so, it is obvious that the leachability of uranium varied dramatically among these sediments. Uranium in the vadose zone can be characterized as highly mobile $\left(\mathrm{K}_{\mathrm{d}}=0.143 \mathrm{~mL} / \mathrm{g}\right)$ to immobile $\left(\mathrm{K}_{\mathrm{d}}\right.$ value of $\left.229 \mathrm{~mL} / \mathrm{g}\right)$. Within the aquifer, uranium can be characterized as partially mobile $\left(K_{d}\right.$ values of 2 to $\left.9 \mathrm{~mL} / \mathrm{g}\right)$ to immobile $\left(\mathrm{K}_{d}\right.$ value of $759 \mathrm{~mL} / \mathrm{g}$ ). Given the range in equilibrium $\mathrm{K}_{\mathrm{d}}$ values (even using the leachable fraction of uranium as the total), it is clear that uranium will continue to leach slowly from these sediments for a substantial period of time.

- The percentage of labile uranium (based on the 28-day carbonate leach samples versus the total uranium concentrations in the microwave digestates) varied considerably within sediments collected from the three TCE wells. In well 399-2-5, the percentage of labile uranium within the vadose zone ranged from 18 to $68 \%$ of the total uranium. Within the aquifer, the percentage of labile uranium in the sediments ranged from 6.3 to $13 \%$. For well $399-3-22$, the ranges varied from 1.3 to $27 \%$ in the vadose zone and capillary fringe sediments and from 2.8 to $18 \%$ in the aquifer sediments. The few sediment samples collected from well 399-4-14 identified 3.4 to $48 \%$ labile uranium in the vadose zone, $24 \%$ labile uranium in the capillary fringe, and 5.8\% labile uranium in the aquifer. In comparison, Zachara et al. (2005) found that 4.2 to $8.1 \%$ of the uranium in the shallow vadose zone 
within the NPP was labile, while approximately 8 to $67 \%$ of the uranium was labile in the deeper sediments collected within the NPP and SPP.

- Within well 399-3-22, the sample with the highest amount of carbonate-leachable uranium was also the sample with the highest equilibrium $\mathrm{K}_{\mathrm{d}}$ (based on the water extract data). Specifically, sample B1PL57-2 had an equilibrium $\mathrm{K}_{\mathrm{d}}$ value of $994 \mathrm{~mL} / \mathrm{g}$. This result implies that the inventory of uranium present at the interface of the vadose zone and aquifer (i.e., the capillary fringe) has the potential to supply the aquifer with contaminant uranium for a substantial period of time. The contaminant uranium present shallower in the vadose zone and deeper (through $64 \mathrm{ft}$ bgs) within the aquifer is considerably more mobile, with equilibrium $K_{d}$ values of $2 \mathrm{~mL} / \mathrm{g}$ or less.

- Contaminated sediments (C4999-11D and C5000-39B) collected from two of the LFI wells at depths near the fluctuating water table showed different long-term U(VI) desorption behavior, depending on U(VI) adsorption capacity, sediment location, and carbonate content in the sediments. Sediment 11D had a higher U(VI) adsorption capacity than sample 39B, which contained more labile U(VI) but was more resistant to U(VI) desorption in the synthetic groundwater solution. Strong U(VI) surface complexes were observed on sample 11D, which was collected in the deep vadose zone (41.5 $\mathrm{ft}$ bgs) close to the Columbia River; however, this sample has been frequently flushed by the episodic rise and fall of groundwater diluted with river water, which has likely removed the readily leachable U(VI) fraction from the sediment. Conversely, sediment 39B, which was collected in the relatively shallow vadose zone ( $23.1 \mathrm{ft} \mathrm{bgs})$ farther inland from the river shore, showed a higher carbonate content in sediment, which can affect U(VI) adsorption and desorption through carbonate dissolution and reprecipitation.

- Desorption of U(VI) using repetitive water extractions was fairly well predicted by an equilibrium model using a monodentate $\mathrm{U}(\mathrm{VI})$ surface complex $\left(\mathrm{SOUO}_{2} \mathrm{HCO}_{3}\right)$ reaction with $\log \mathrm{K}$ values of 17.2 and 16.6 for samples 11D and 39B, respectively. However, because of the kinetic resupply of desorbed $\mathrm{U}(\mathrm{VI})$ at longer reaction times, the equilibrium model underestimated U(VI) desorption from sample 11D; therefore, a kinetic component should be included to better predict U(VI) desorption in multistep batch and column systems, especially for longer reaction times.

- Although U(VI) desorption from the 300 Area sediments is complex and depends on many factors only partially elucidated by the macroscopic batch and modeling results presented in this study, the river water influx and mixing with groundwater or pore water in the capillary fringe results in highly dynamic changes in pore water chemistry and is a principal mechanism controlling the continuous resupply of dissolved U(VI) to the existing 300 Area groundwater plume. That is, U(VI) from the contaminated sediments both above and right below the fluctuating water table is slowly entering the 300 Area groundwater system through desorption and/or dissolution processes. In addition, the dissolved U(VI) can also be re-adsorbed to sediments due to decreased carbonate concentrations as the water elevation rises into the vadose zone during high river stage (i.e., the more saline groundwater becomes diluted by Columbia River water). This fluctuating water table elevation and varying pore water chemical composition caused by seasonal and diurnal variations in the river stage result in alternating adsorption-desorption processes that keep large quantities of $\mathrm{U}(\mathrm{VI})$ from migrating to the Columbia River in a timely fashion.

- It must be noted that all of the characterization activities included in this report were performed on sediment material $<2 \mathrm{~mm}$ in diameter. Sediments collected within the 300 Area are quite coarse and include a substantial amount of gravel. In some cases, less than $10 \%$ of the material within the core or grab samples characterized was $<2 \mathrm{~mm}$ in diameter. Therefore, additional consideration should be 
used when applying the results contained in this report at the field-scale. For example, when the $>$ $2 \mathrm{~mm}$ size fraction is assumed to be unreactive, as would be the case for the partitioning $\left(\mathrm{K}_{\mathrm{d}}\right)$ of uranium, the $\left(\mathrm{K}_{\mathrm{d}}\right)$ values reported herein would need to be reduced by up to an order of magnitude to be representative of the bulk sediment.

The mobility characteristics of uranium vary within the multiple subsurface zones that contain residual contaminant uranium. Principal subsurface zones include 1) the vadose zone, 2) a zone through which the water table rises and falls, 3) the aquifer, and 4) a zone where groundwater and river water interact beneath the river shoreline. Principal controls on mobilization include the form of the residual uranium (e.g., crystalline minerals, amorphous precipitates/coatings, or sorbed onto sediment), the transporting medium (e.g., water infiltration from the land surface, groundwater), and the rate of exchange between the residual uranium and transporting medium. The bicarbonate content of aqueous media strongly influences the rate of exchange, with relatively higher bicarbonate content enhancing mobility. Groundwater has a higher bicarbonate content than river water or other fresh water sources, such as utility and potable water systems.

The inventory of contaminant uranium that continues to supply the groundwater plume was modeled by Peterson et al. (2008a) as having 10 subsurface compartments. Of these 10, Peterson et al. (2008a) estimated that the largest inventory is that of the 300 Area vadose zone, while the second largest compartment is the region beneath the 300 Area through which the water table rises and falls. The former compartment is a less likely current contributor to groundwater contamination because of the relatively more-resistant form of uranium and the low moisture flux. The latter zone is a more likely the current contributor because of periodic saturation by groundwater and a possibly less retentive form of uranium in the intermittently wetted sediment. Peterson et al. (2008a) estimated that the inventory of uranium in the aquifer, as dissolved and sorbed forms, is estimated to represent $\sim 5 \%$ of the total inventory calculated for the 10 compartments.

Based on results from the present study, it appears that uranium contamination in the 300 Area vadose zone can be characterized using a two-source model. The first source is fairly widespread, with an areal extent as large as the total 300 Area footprint that has been affected by fluctuations in river stage (i.e., elevated water table during times of high river stage). The uranium within this source is concentrated in the deeper vadose zone and capillary fringe, also known as the "smear zone," and is likely present at total concentrations ranging from 3 to $10 \mu \mathrm{g} / \mathrm{g}$ of sediment. The second source term is much more variable and has a much smaller footprint within the 300 Area. This source can be classified as containing "hot spots" of contaminant uranium at depths ranging from ground surface to the top of the unconfined aquifer. While uranium contamination from this second source term was not encountered as part of this investigation, previous studies (e.g., Serne et al. 2002) have reported concentrations in excess of $900 \mu \mathrm{g} \mathrm{U} / \mathrm{g}$ of sediment in the 300 Area. While remediation activities performed by the River Corridor Contractor have removed a significant amount of this source from the abandoned liquid waste disposal facilities, pore waters generated prior to removal of the sediments are likely making their way to the aquifer. Based on results reported by Serne et al. (2002), these pore waters could contain more than 23,000 $\mu \mathrm{g} / \mathrm{L}$ dissolved uranium.

The current conceptual model for uranium contamination in the subsurface at the 300 Area (updated after Peterson et al. 2008a) has significant implications for the selection and implementation of a remedial action technology. A current working assumption that remediating contamination in the vadose zone directly beneath former liquid-waste disposal facilities will provide a significant reduction in the 
persistent uranium plume in groundwater appears to be less certain. As such, a technology capable of remediating a large footprint of sediments contaminated with low concentrations of uranium may also be necessary. The technology now being tested involves injecting polyphosphate solution into the aquifer to sequester dissolved uranium (Wellman et al. 2005, 2006a, 2006b). While this technology looks promising in its ability to sequester (in place) contaminant uranium, it appears that the application will need to be more widespread to significantly reduce the inventory of contaminant uranium replenishing the 300 Area groundwater plume. 



\subsection{References}

Arai Y, MA Marcus, N Tamura, JA Davis, and JM Zachara. 2007. "Spectroscopic evidence for uranium bearing precipitates in vadose zone sediments at the Hanford 300-Area site." Environ. Sci. Technol. 41, 4633-4639.

Bjornstad BN. 2004. Sampling and Hydrogeology of the Vadose Zone Beneath the 300 Area Process Ponds. PNNL-14834, Pacific Northwest National Laboratory, Richland, Washington.

Bond DL, JA Davis, and JM Zachara. 2008. "Uranium(VI) release from contaminated vadose zone sediments: Estimation of potential contributions from dissolution and desorption." Adsorption of metals by geomedia II: Variables, Mechanisms, and Model Applications (MO Barnett and DB Kent, Eds.). Elsevier, Amsterdam, The Netherlands.

Catalano JG, JP McKinley, JM Zachara, SC Heald, SC Smith, and GE Brown. 2006. "Changes in uranium speciation through a depth sequence of contaminated Hanford sediments." Environ. Sci. Technol. 40, 2517-2524.

Davis JA, DE Meece, M Kohler, and GP Curtis. 2004. “Approaches to surface complexation modeling of Uranium (VI) adsorption on aquifer sediments." Geochimica et Cosmochimica Acta 68, 3621-3641.

Dong WM, WP Ball, CX Liu, ZM Wang, AT Stone, J Bai, and JM Zachara. 2005. "Influence of calcite and dissolved calcium on uranium(VI) sorption to a Hanford subsurface sediment." Environmental Science \& Technology 39, 7949-7955.

Environmental Protection Agency (EPA). 1984. "Test Method for the Determination of Inorganic Anions in Water by Ion Chromatography.” EPA-600/4-84-017, Method 300.0A, U.S. Environmental Protection Agency, Washington, D.C.

Environmental Protection Agency (EPA). 1996. "Microwave Assisted Digestion of Siliceous and Organically Based Matrices," Method 3052, Revision 0. Test Methods for Evaluating Solid Wastes:

Physical/Chemical Methods, EPA SW-846, Third Ed., Vol. I, Section A, Chapter 3, pp. 3052-1-3052-20, U.S. Environmental Protection Agency, Office of Solid Waste and Emergency Response, Washington, D.C. Available at http://www.epa.gov/epaoswer/hazwaste/test/pdfs/3052.pdf.

Environmental Protection Agency (EPA). 2000. "Acid Digestion of Sediments, Sludges, and Soils." Test Methods for Evaluating Solid Waste, Physical/Chemical Methods. EPA Publication SW-846, Method 3050B. Environmental Protection Agency, Washington, D.C. Available at http://www.epa.gov/epaoswer/hazwaste/test/sw846.htm.

Gaylord DR and EP Poeter. 1991. Geology and Hydrology of the 300 Area and Vicinity, Hanford Site, South-Central Washington. WHC-EP-0500, Westinghouse Hanford Company, Richland, Washington.

Gerber MS. 1992. Past Practices Technical Characterization Study-300 Area-Hanford Site. WHCMR-0388, Westinghouse Hanford Company, Richland, Washington.

Hartman MJ, LF Morasch, and WD Webber. 2005. Hanford Site Groundwater Monitoring for Fiscal Year 2004. PNNL-15070, Pacific Northwest National Laboratory, Richland, Washington. 
Herberlin AL and JC Westall. 1999. FITEQL: A computer program for the determination of chemical equilibrium constants from experimental data. Report 99-01, Chemistry Department, Oregon State University, Corvallis, Oregon.

Horner JA. 2008. Borehole Summary Report for 300-FF-5 Operable Unit TCE Characterization Monitoring Wells C5575, C5706, C5707, and C5708. SGW-36424, Rev. 0, prepared by GRAM, Inc. for Fluor Hanford, Inc., Richland, Washington.

Kalmykov SN and GR Choppin. 2000. "Mixed Ca2+/ $\mathrm{UO}_{2}{ }^{2+} / \mathrm{CO}_{3}{ }^{2-}$ complex formation at different ionic strengths.” Radiochimica Acta 88, 603-606.

Kohler M, GP Curtis, DE Meece, and JA Davis. 2004. "Methods for Estimating Adsorbed Uranium(VI) and Distribution Coefficients of Contaminated Sediments." Environmental Science \& Technology $38(1): 240-247$.

Kooiker CA, RE Peterson, SM Smith, and BA Williams. 2007. Sampling and Analysis Instructions for TCE Characterization, 300-FF-5 Operable Unit, Fiscal Year 2007. SGW-32607, Rev. 0, Fluor Hanford, Inc., Richland, Washington.

Langmuir D. 1997. Aqueous Environmental Geochemistry. Prentice Hall, Upper Saddle River, New Jersey.

Lindsey KA. 1995. Miocene- to Pliocene-Aged Suprabasalt Sediments of the Hanford Site, SouthCentral Washington. BHI-00184 Rev. 00, Bechtel Hanford, Inc., Richland, Washington.

Liu C, JM Zachara, N Qafoku, and Z Wang. 2008. "Scale-dependent desorption of uranium from contaminated subsurface sediments." Water Resources Research (in press).

Liu CX, JM Zachara, W Yantasee, PD Majors, and JP McKinley. 2006. "Microscopic reactive diffusion of uranium in the contaminated sediments at Hanford, United States." Water Resources Research 42, Art. No. W12420.

Liu C, JM Zachara, O Qafoku, JP McKinley, SM Heald, and Z Wang. 2004. "Dissolution of Uranyl Microprecipitates from Subsurface Sediments at Hanford Site, USA." Geochimica et Cosmochimica Acta 68(22):4519-4537.

McKinley JP, JM Zachara, C Liu, SC Heald, BI Prenitzer, and BW Kempshall. 2006. "Microscale controls on the fate of contaminant uranium in the vadose zone, Hanford Site, Washington." Geochimica et Cosmochimica Acta 70, 1873-1887.

NAD83. 1991. North American Datum of 1983. National Geodetic Survey, Federal Geodetic Control Committee, Silver Spring, Maryland, as revised.

NAVD88. 1988. North American Vertical Datum of 1988. National Geodetic Survey, Federal Geodetic Control Committee, Silver Spring, Maryland.

Peterson RE (Ed.). 2005. Contaminants of Potential Concern in the 300-FF-5 Operable Unit: Expanded Annual Groundwater Report for FY 2004. PNNL-15127, Pacific Northwest National Laboratory, Richland, Washington. 
Peterson RE, RJ Serne, PD Thorne, MD Williams, and ML Rockhold. 2008a. Uranium Contamination in the Subsurface Beneath the 300 Area, Hanford Site, Washington. PNNL-17034, Pacific Northwest National Laboratory, Richland, Washington.

Peterson RE, BA Williams, and RM Smith. 2008b. Volatile Organic Compounds Investigation Results, 300 Area, Hanford Site, Washington. PNNL-17666, Pacific Northwest National Laboratory, Richland, Washington.

Qafoku NP, JM Zachara, C Liu, PL Gassman, OS Qafoku, and SC Smith. 2005. "Kinetic desorption and sorption of U(VI) during reactive transport in a contaminated Hanford sediment." Environ. Sci. Technol. 39, 3157-3165.

Serne RJ, CF Brown, HT Schaef, EM Pierce, MJ Lindberg, Z Wang, PL Gassman, and JG Catalano. 2002a. 300 Area leach and adsorption project. PNNL-14022, Pacific Northwest National Laboratory, Richland, Washington.

Serne RJ, HT Schaef, BN Bjornstad, DC Lanigan, GW Gee, CW Lindenmeier, RE Clayton, VL LeGore, MJ O'Hara, CF Brown, RD Orr, GV Last, IV Kutnyakov, DS Burke, TC Wilson, and BA Williams. 2002b. Characterization of Vadose Zone Sediment: Borehole 299-W23-19 [SX 115] in the S-SX Waste Management Area. PNNL-13757-2, Pacific Northwest National Laboratory, Richland, Washington.

Serne RJ, GV Last, HT Schaef, DC Lanigan, CW Lindenmeier, CC Ainsworth, RE Clayton, VL LeGore, MJ O'Hara, CF Brown, RD Orr, IV Kutnyakov, TC Wilson, KB Wagnon, BA Williams, and DB Burke. 2002c. Characterization of Vadose Zone Sediment, Part 4: Slant Borehole SX-108 in the S-SX Waste Management Area. PNNL-13757-4, Pacific Northwest National Laboratory, Richland, Washington.

Serne RJ, GV Last, GW Gee, HT Schaef, DC Lanigan, CW Lindenmeier, RE Clayton, VL LeGore, RD Orr, MJ O'Hara, CF Brown, DS Burke, AT Owen, IV Kutnyakov, and TC Wilson. 2002d. Characterization of Vadose Zone Sediment: Borehole 41-09-39 in the S-SX Waste Management Area. PNNL-13757-3, Pacific Northwest National Laboratory, Richland, Washington.

Serne RJ, GV Last, GW Gee, HT Schaef, DC Lanigan, CW Lindenmeier, MJ Lindberg, RE Clayton, VL LeGore, RD Orr, IV Kutnyakov, SR Baum, KN Geiszler, CF Brown, MM Valenta, and TS Vickerman. 2002e. Characterization of Vadose Zone Sediment: Borehole 299-E33-45 Near BX-102 in the B-BX-BY Waste Management Area. PNNL-14083, Pacific Northwest National Laboratory, Richland, Washington.

Serne RJ, BN Bjornstad, GW Gee, HT Schaef, DC Lanigan, CW Lindenmeier, RD Orr, VL LeGore, RE Clayton, MJ Lindberg, IV Kutnyakov, SR Baum, KN Geiszler, MM Valenta, TS Vickerman, and LJ Royack. 2002f. Characterization of Vadose Zone Sediment: Borehole 299-E33-46 Near B-110 in the B BX BY Waste Management Area. PNNL-14119, Pacific Northwest National Laboratory, Richland, Washington.

Swanson LC, GG Kelty, KA Lindsey, KR Simpson, RK Price, and SD Consort. 1992. Phase I Hydrogeologic Summary of the 300-FF-5 Operable Unit, 300 Area. WHC-SD-EN-TI-052 Rev. 0, Westinghouse Hanford Company, Richland, Washington.

U.S. Geological Study (USGS). 2001. Alkalinity and Acid Neutralizing Capacity. National Field Manual for Collection of Water-Quality Data, 2nd ed. (SA Rounds and FD Wilde, eds.). USGS, http://water.usgs.gov/owq/FieldManual/Chapter6/section6.6/html/section6.6.htm. 
Wang Z, JM Zachara, JP McKinley, and SC Smith. 2005. "Cryogenic laser induced U(VI) fluorescence studies of a U(VI) substituted natural calcite: Implications to U(VI) speciation in contaminated Hanford sediments." Environ. Sci. Technol. 39, 2651-2659.

Wellman DM, JG Catalono, JP Icenhower, and AP Gamerdinger. 2005. "Synthesis and characterization of sodium meta-autunite, $\mathrm{Na}\left[\mathrm{UO}_{2} \mathrm{PO}_{4}\right] .3 \mathrm{H}_{2} \mathrm{O}$.” Radiochimica Acta 93, 393-399.

Wellman DM, JP Icenhower, AP Gamerdinger, and SW Forrester. 2006a. "Effects of pH, temperature, and aqueous organic material on the dissolution kinetics of meta-autunite minerals, (Na, Ca)21[(UO2)(PO4)]23H2O." American Mineralogist 91, 143-158.

Wellman DM, JP Icenhower, and AT Owen. 2006b. "Comparative analysis of soluble phosphate amendments for the remediation of heavy metal contaminants: Effect on sediment hydraulic conductivity." Environmental Chemistry 3, 219-224.

Williams BA, CF Brown, W Um, MJ Nimmons, RE Peterson, BN Bjornstad, DC Lanigan, RJ Serne, FA Spane, and ML Rockhold. 2007. Limited Field Investigation Report for Uranium Contamination in the 300 Area, 300-FF-5 Operable Unit, Hanford Site, Washington. PNNL-16435, Pacific Northwest National Laboratory, Richland, Washington.

Zachara JM, JA Davis, C Liu, JP McKinley, N Qafoku, DM Wellman, and SB Yabusaki. 2005. Uranium Geochemistry in Vadose Zone and Aquifer Sediments from the 300 Area Uranium Plume. PNNL-15121, Pacific Northwest National Laboratory, Richland, Washington.

Zachara J, CF Brown, C Liu, S Kelly, J Christensen, J McKinley, JA Davis, RJ Serne, E Dresel, and W Um. 2007. A Site-Wide Perspective on Uranium Geochemistry at the Hanford Site. PNNL-17031, Pacific Northwest National Laboratory, Richland. 


\section{Appendix A}

Composite Borehole Logs for VOC Investigation 


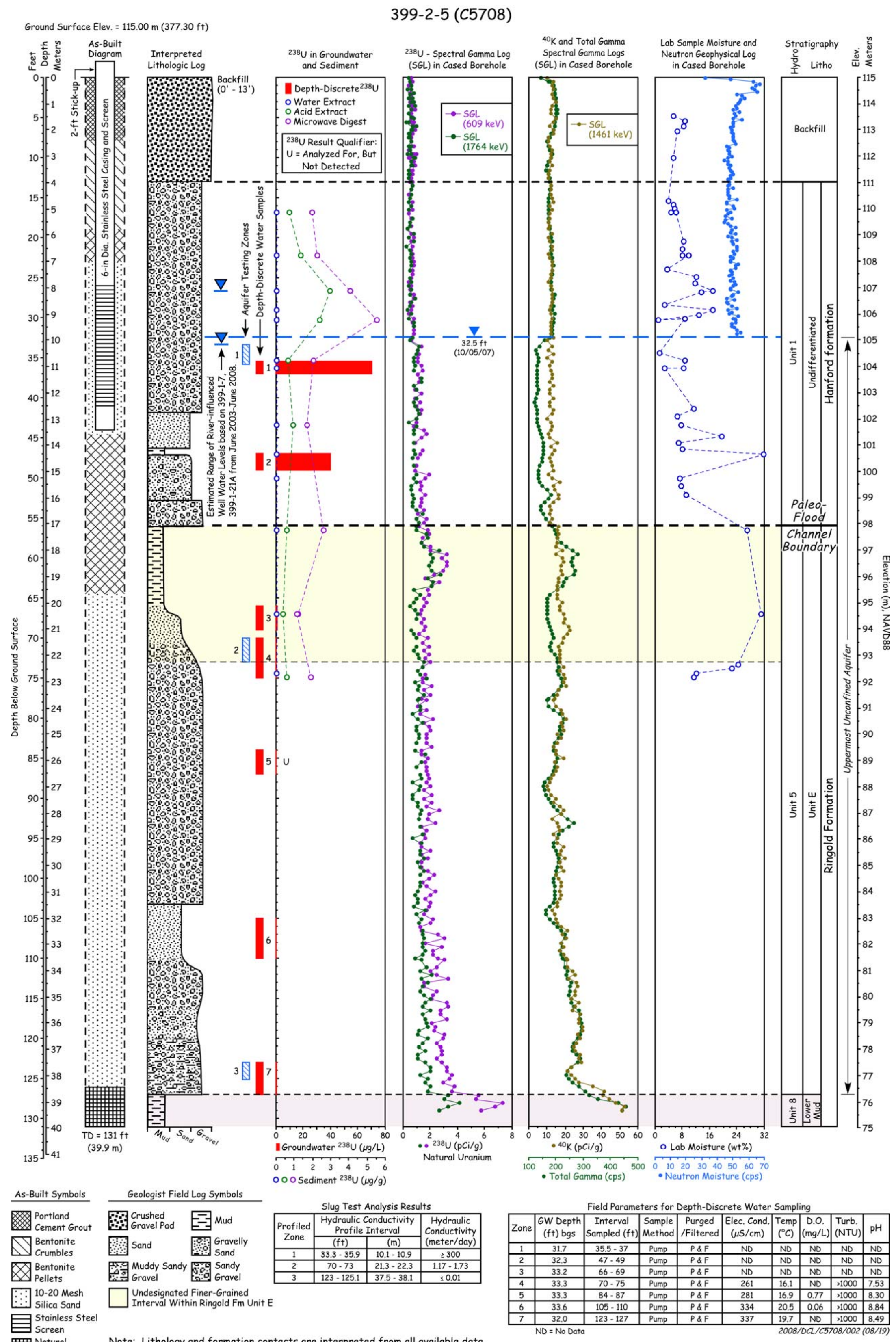

Figure A.1. Composite Borehole Log for Borehole 399-2-5 (C5708) 


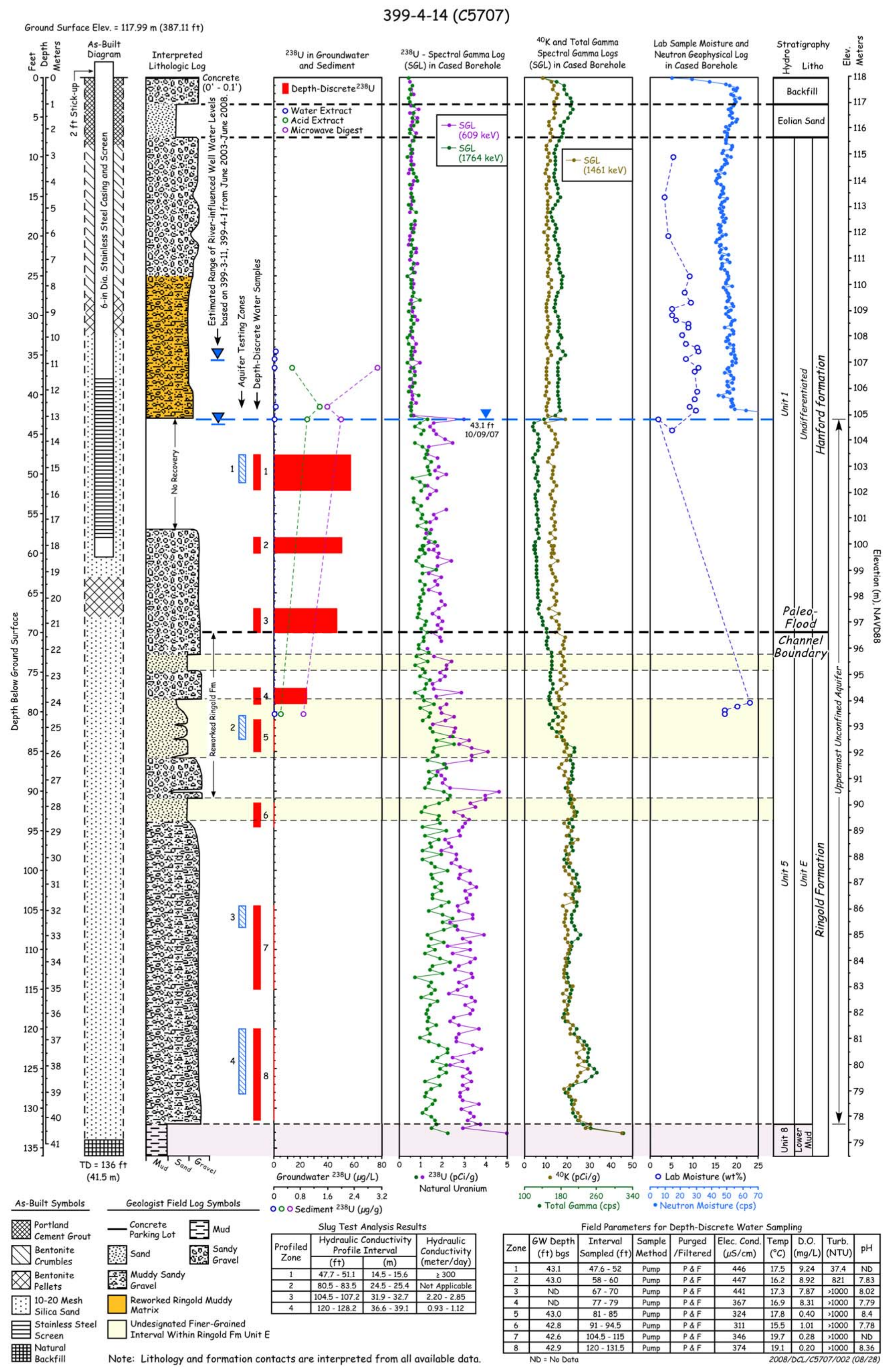

Figure A.2. Composite Borehole Log for Borehole 399-4-14 (C5707) 


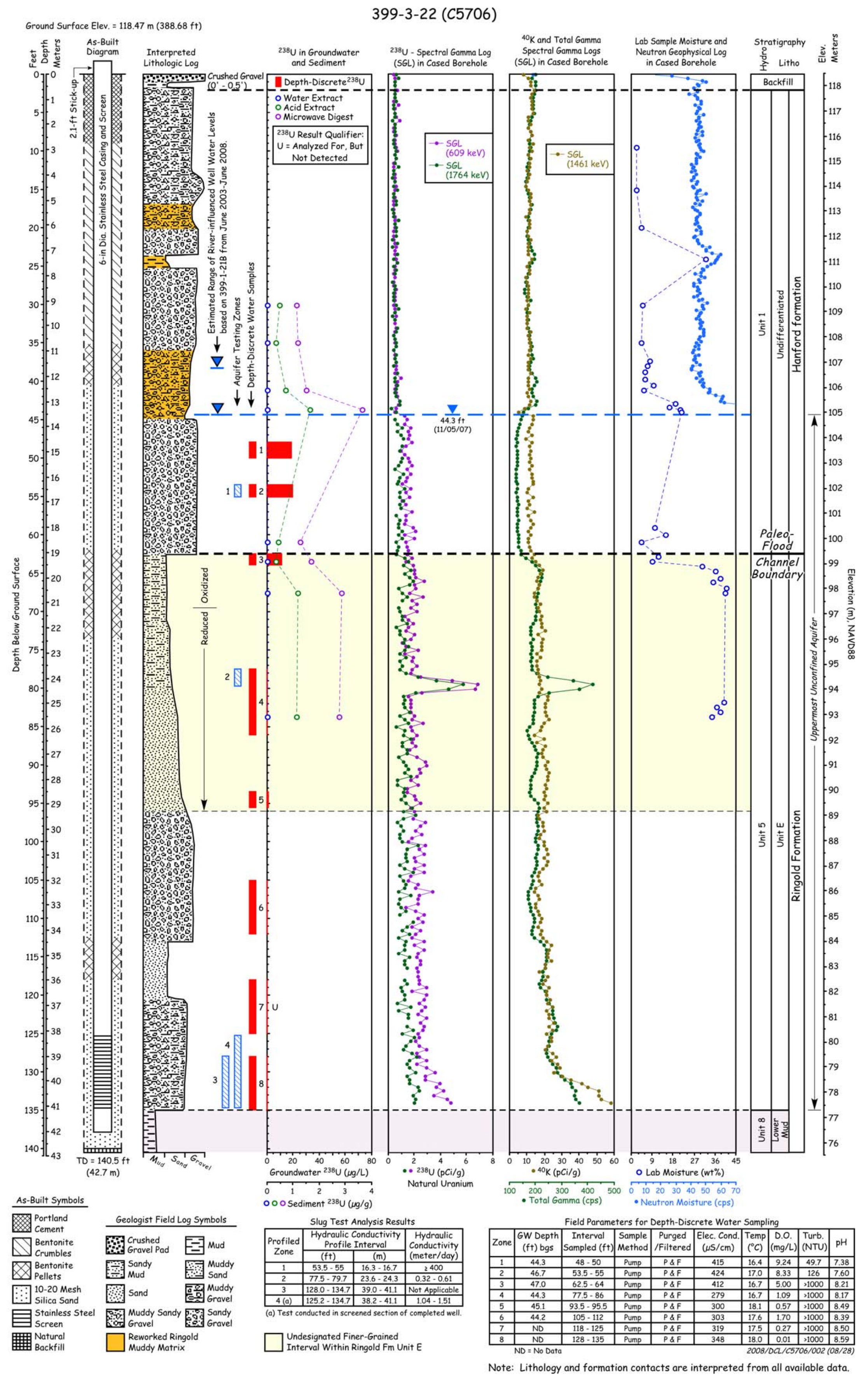

Figure A.3. Composite Borehole Log for Borehole 399-3-22 (C5706) 



\section{Appendix B}

\section{Geologist Logs for Uranium Investigation Boreholes}





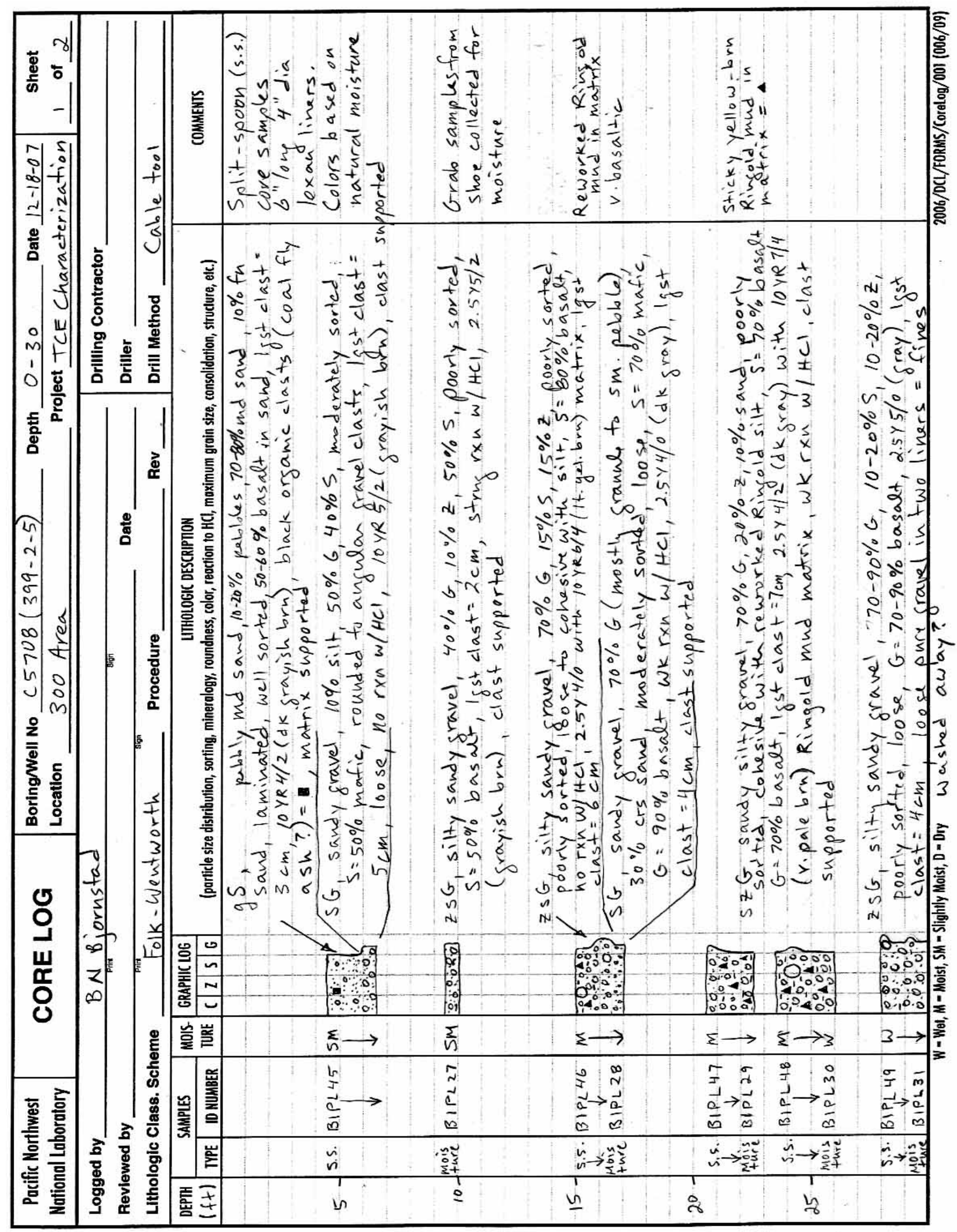

Figure B.1. Core Log for Borehole 399-2-5 (C5708) from 5 to $25 \mathrm{ft} \mathrm{bgs}$ 


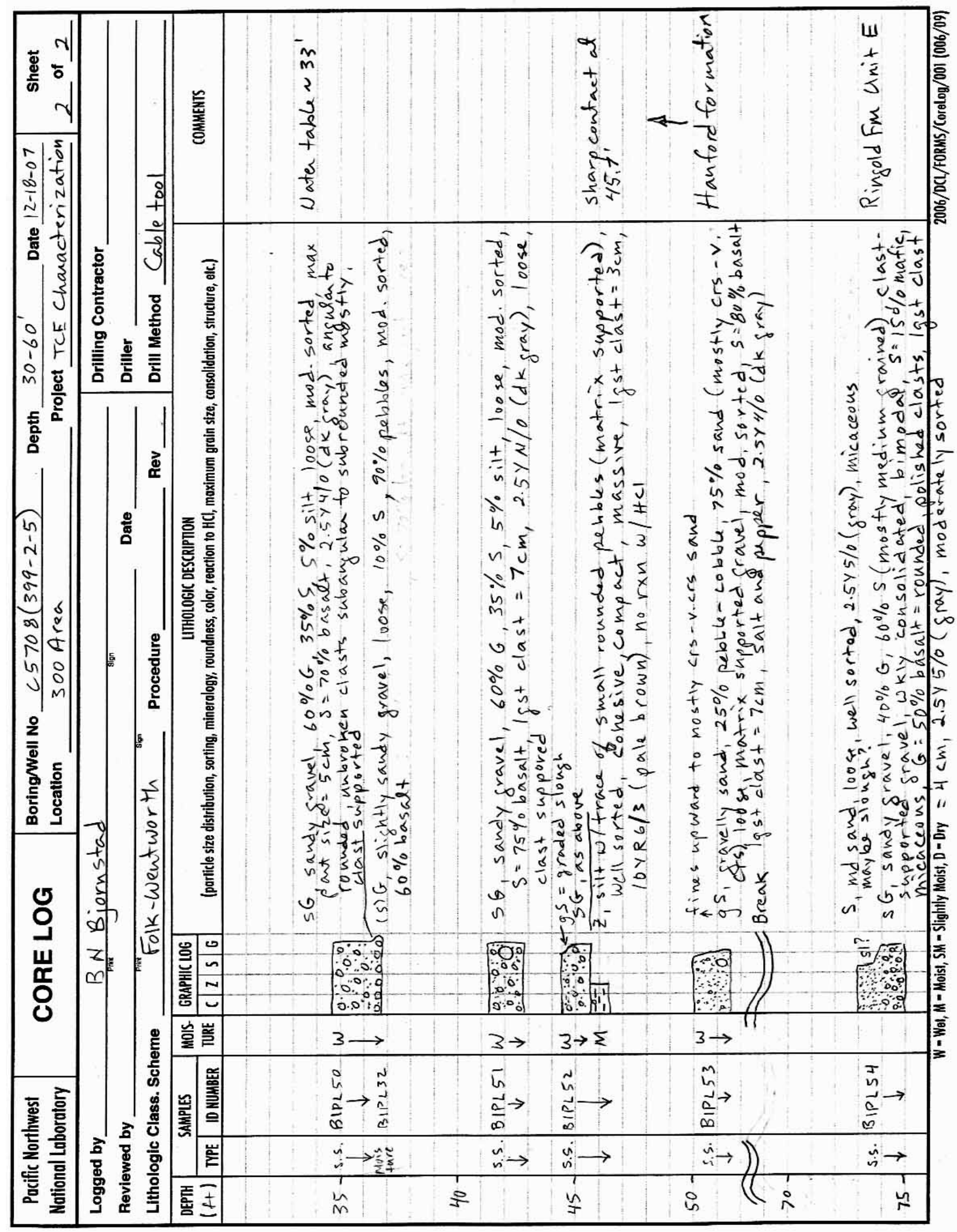

Figure B.2. Core Log for Borehole 399-2-5 (C5708) from 35 to $75 \mathrm{ft}$ bgs 


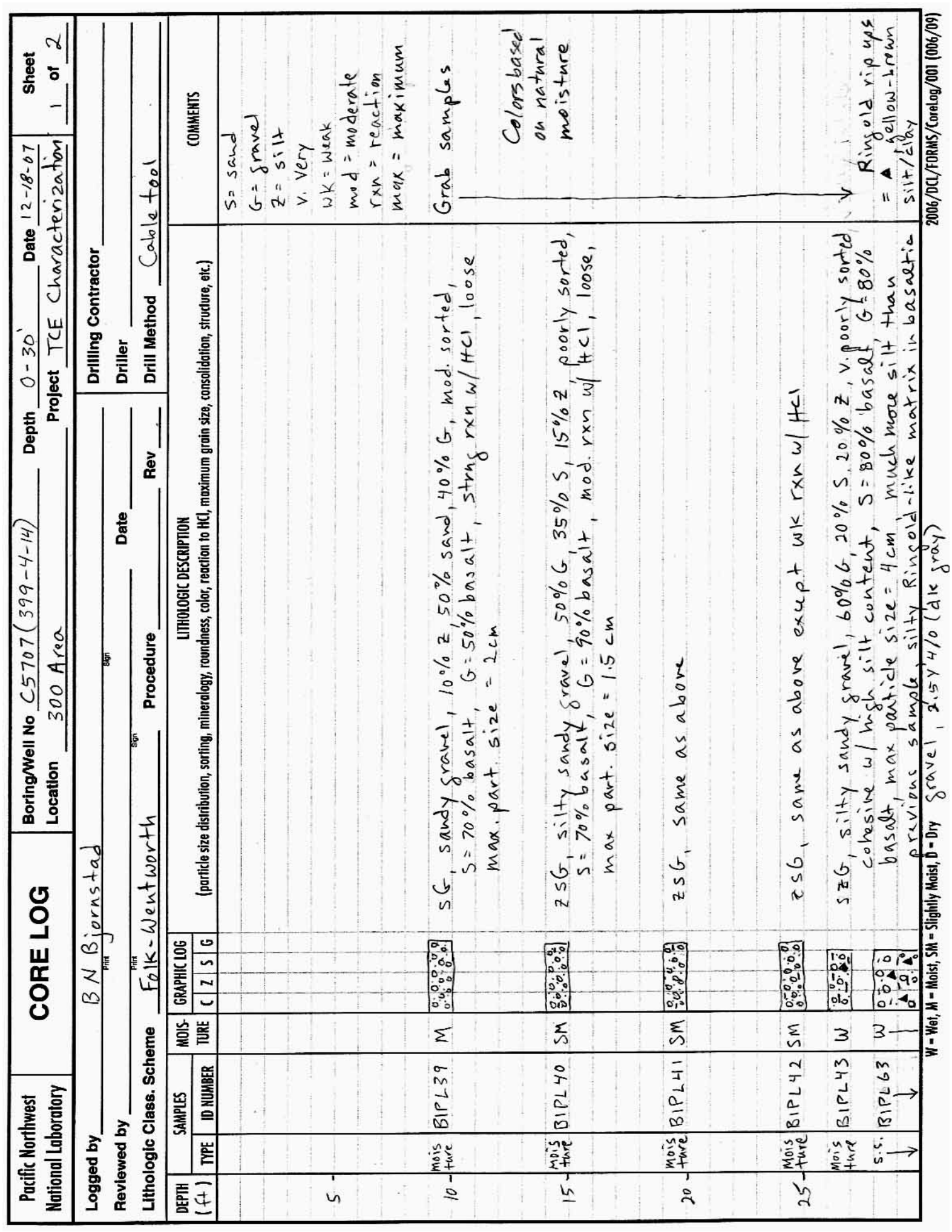

Figure B.3. Core Log for Borehole 399-4-14 (C5707) from 10 to $30 \mathrm{ft}$ bgs 


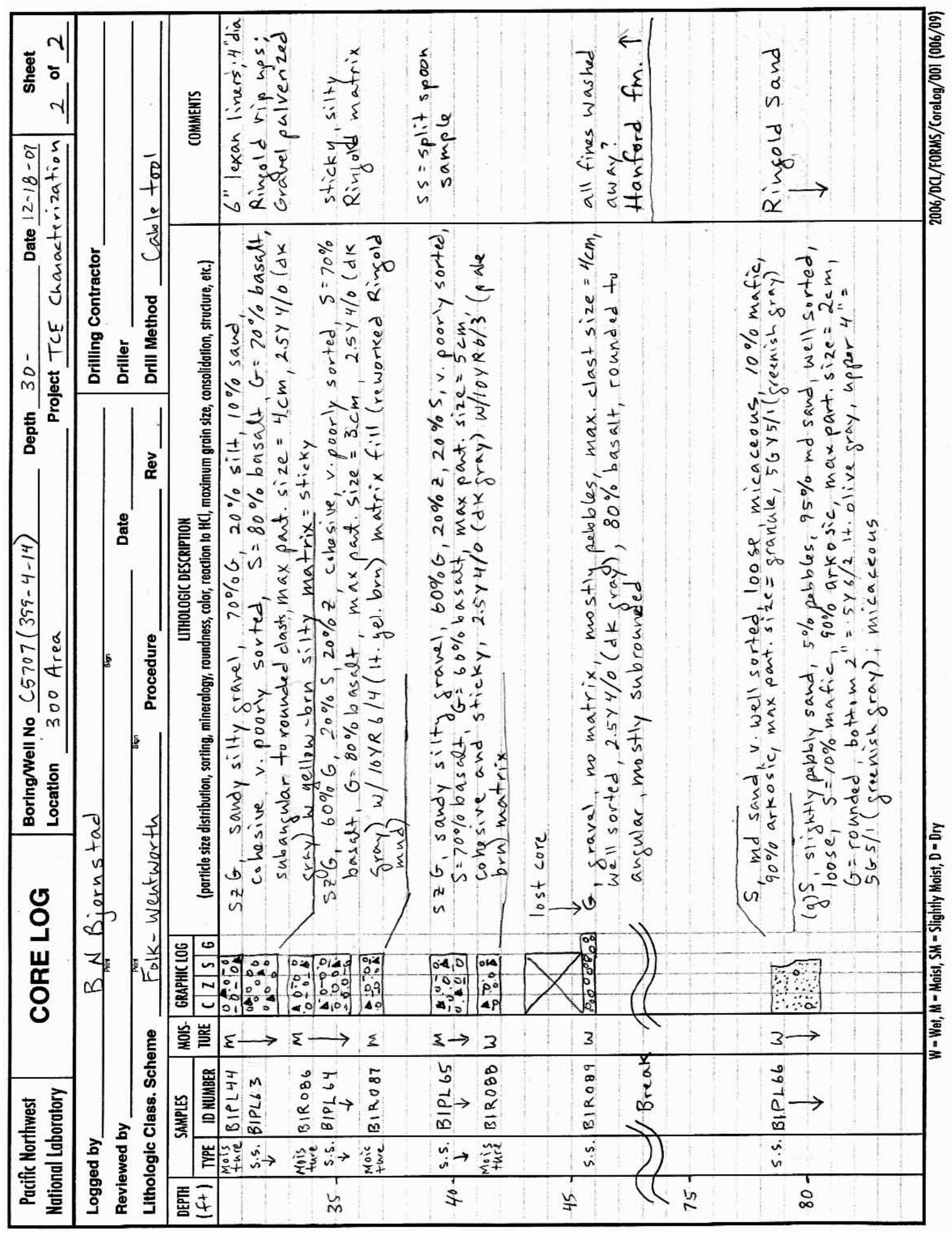

Figure B.4. Core Log for Borehole 399-4-14 (C5707) from 30 to $80 \mathrm{ft}$ bgs 


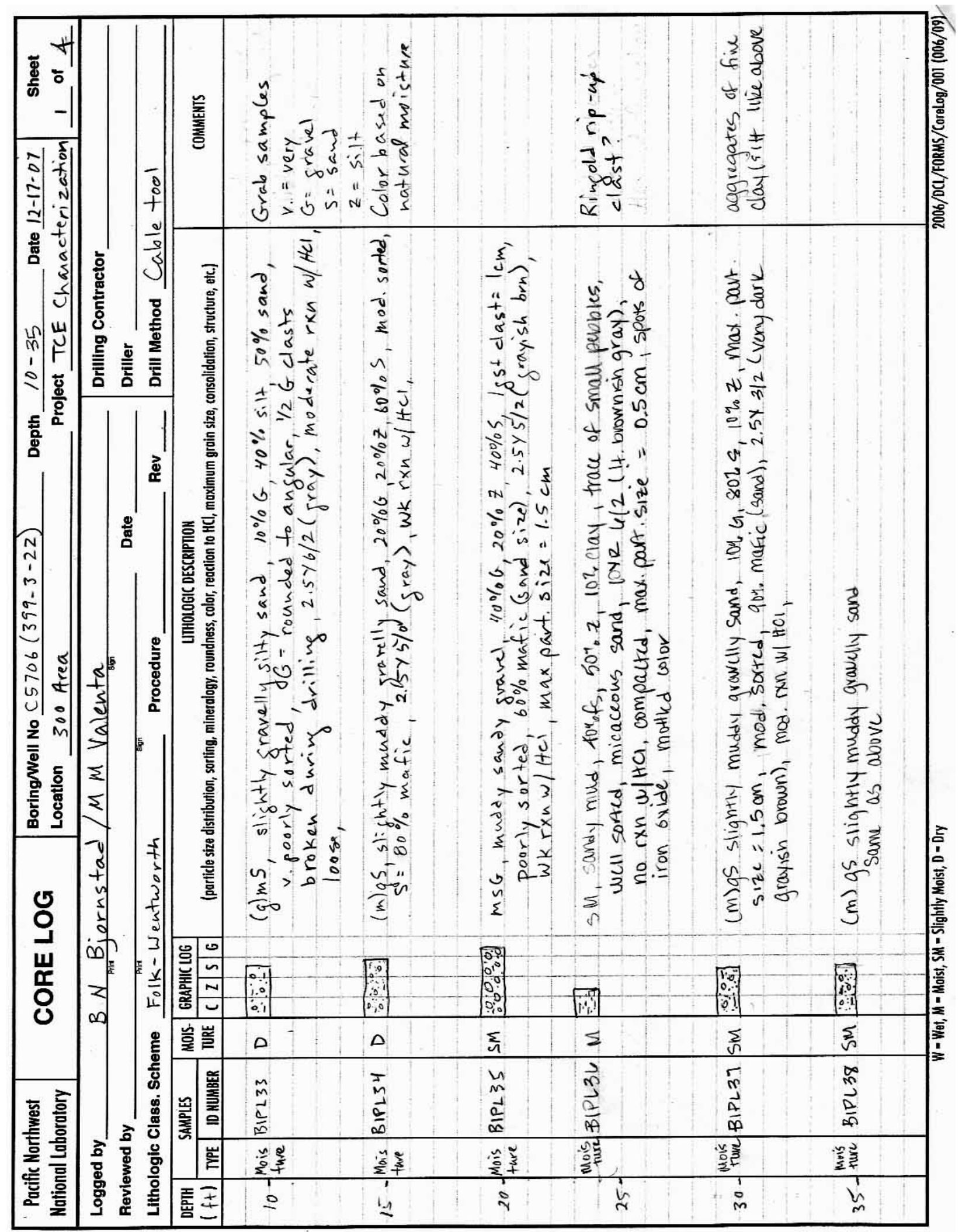

Figure B.5. Core Log for Borehole 399-3-22 (C5706) from 10 to $35 \mathrm{ft}$ bgs 


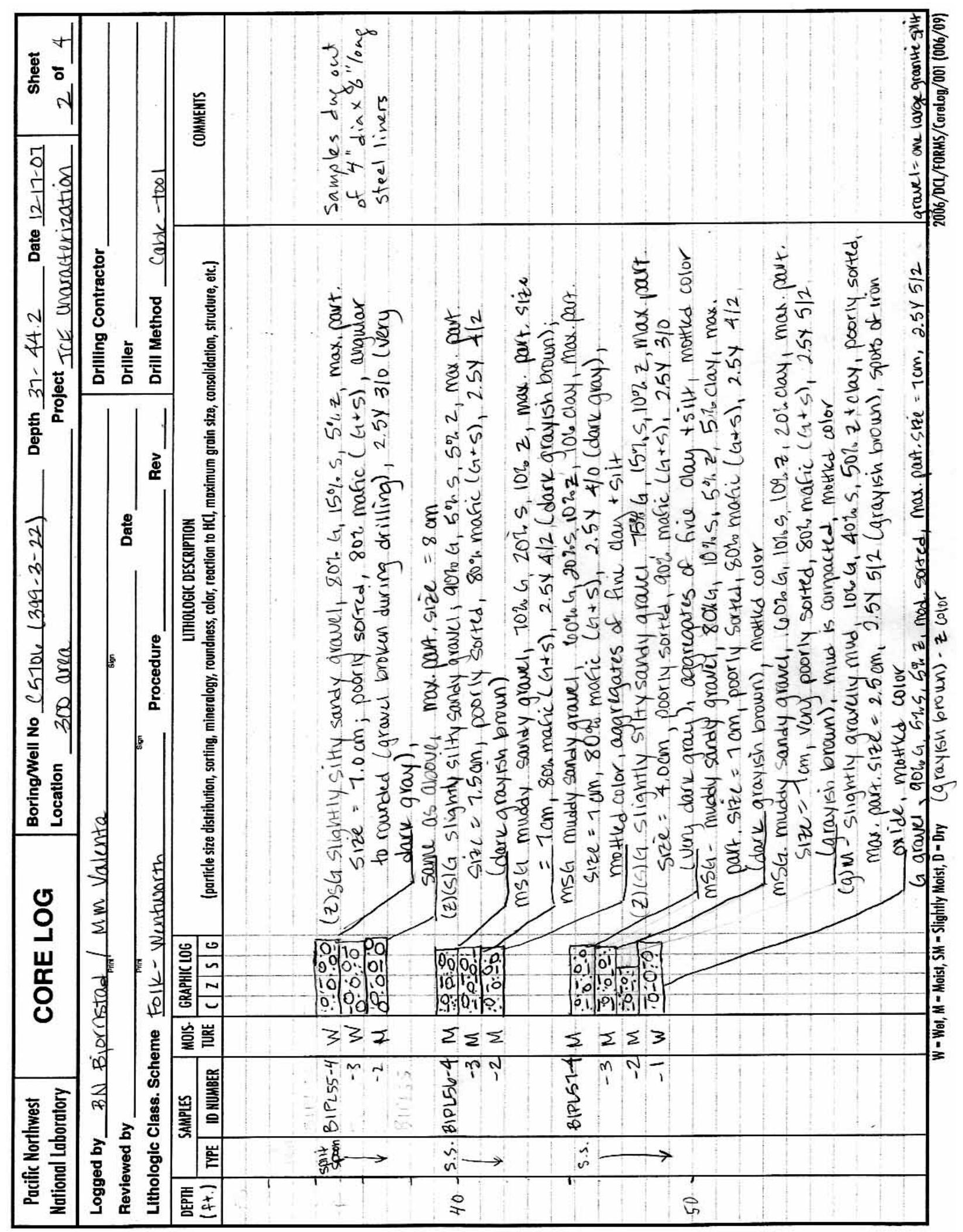

Figure B.6. Core Log for Borehole 399-3-22 (C5706) from 35 to $50 \mathrm{ft}$ bgs 


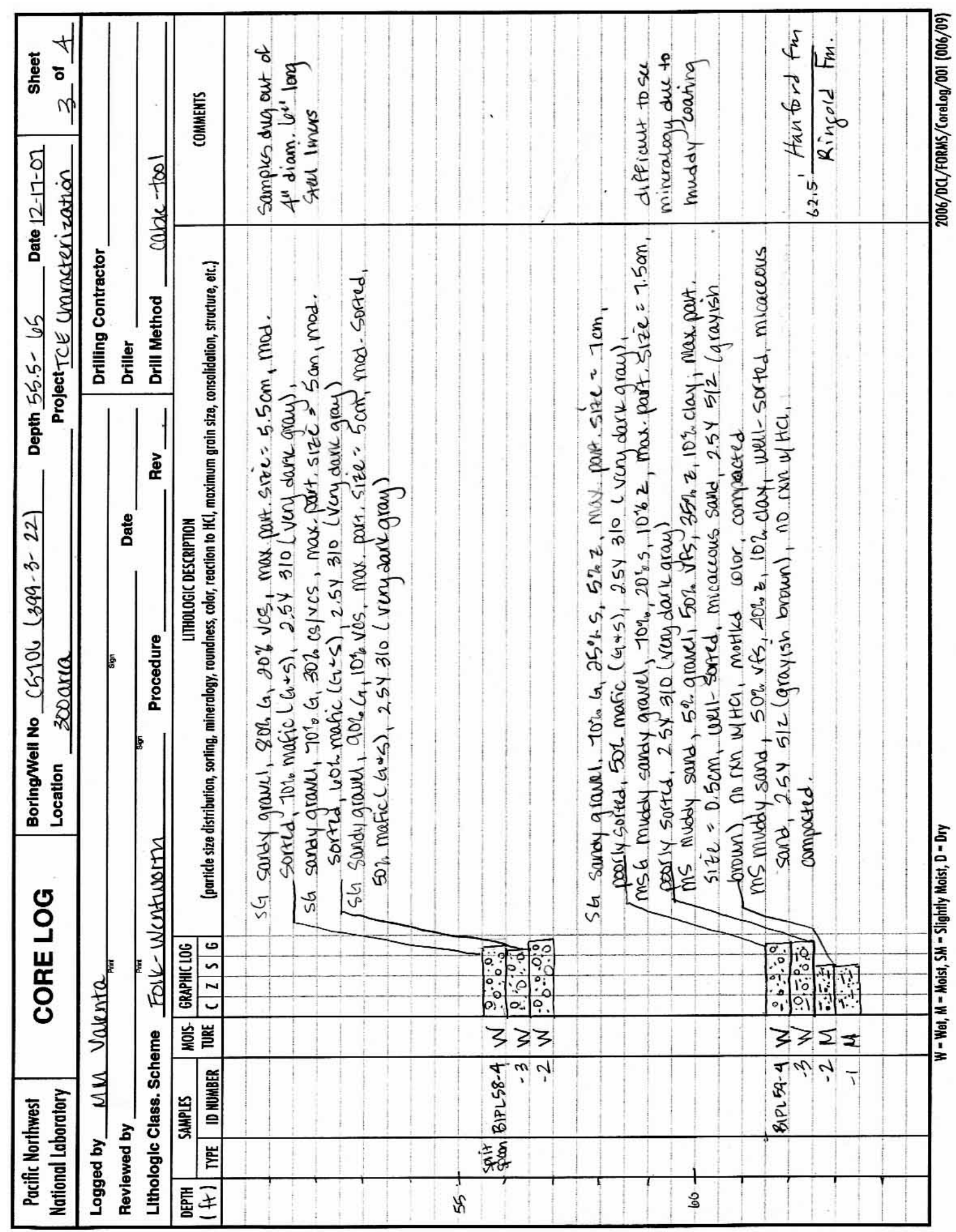

Figure B.7. Core Log for Borehole 399-3-22 (C5706) from 55 to $65 \mathrm{ft}$ bgs 


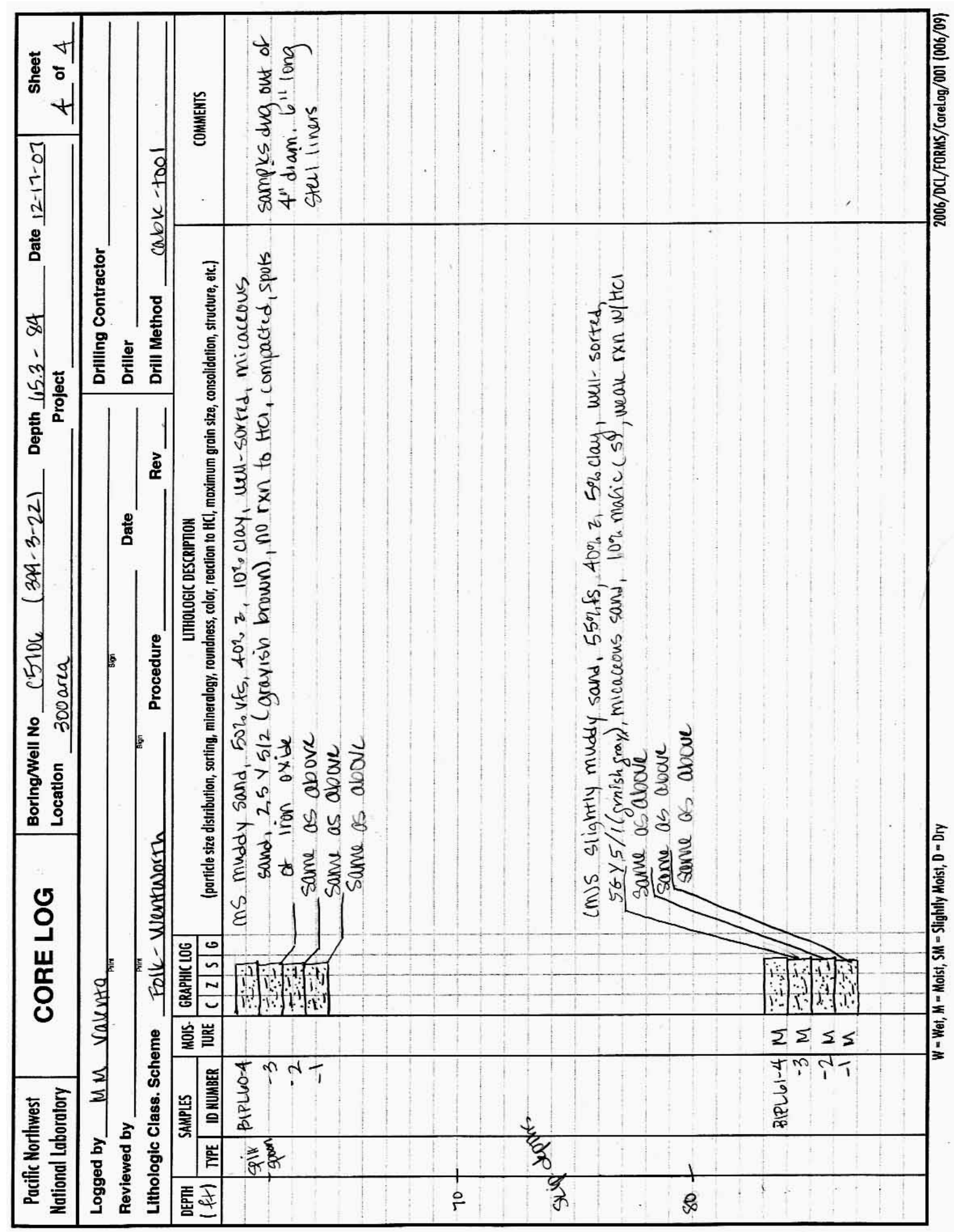

Figure B.8. Core Log for Borehole 399-3-22 (C5706) from 65 to $85 \mathrm{ft}$ bgs 


\section{Appendix C}

Photographs of Samples Collected from Borehole C5708 



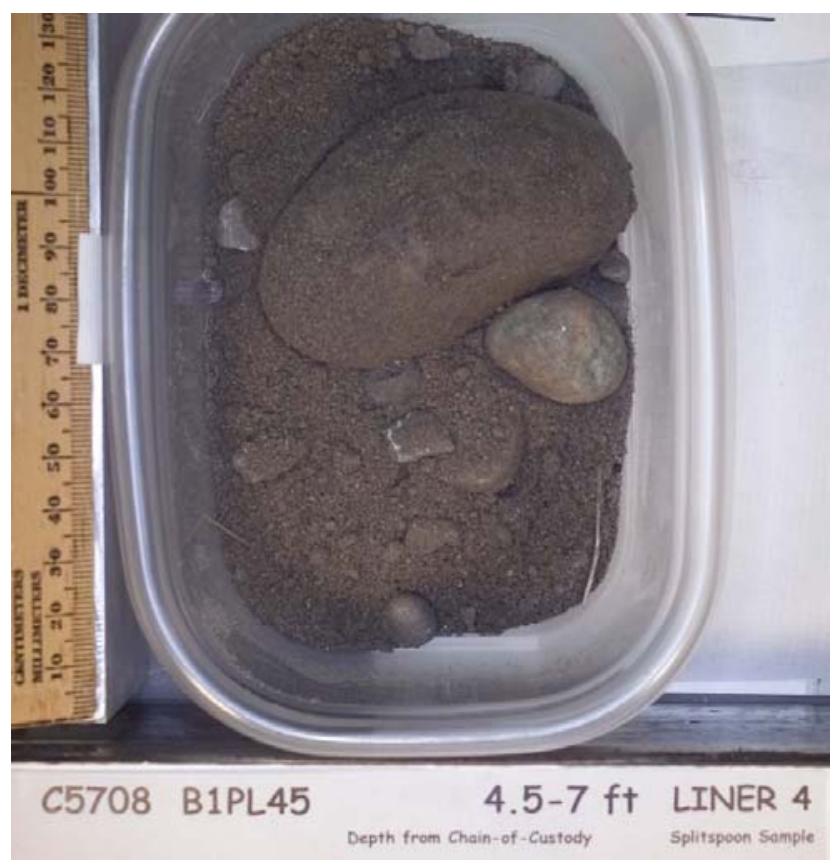

Figure C.1. Photograph of Liner 4 from Sample B1PL45 (Borehole 399-2-5)

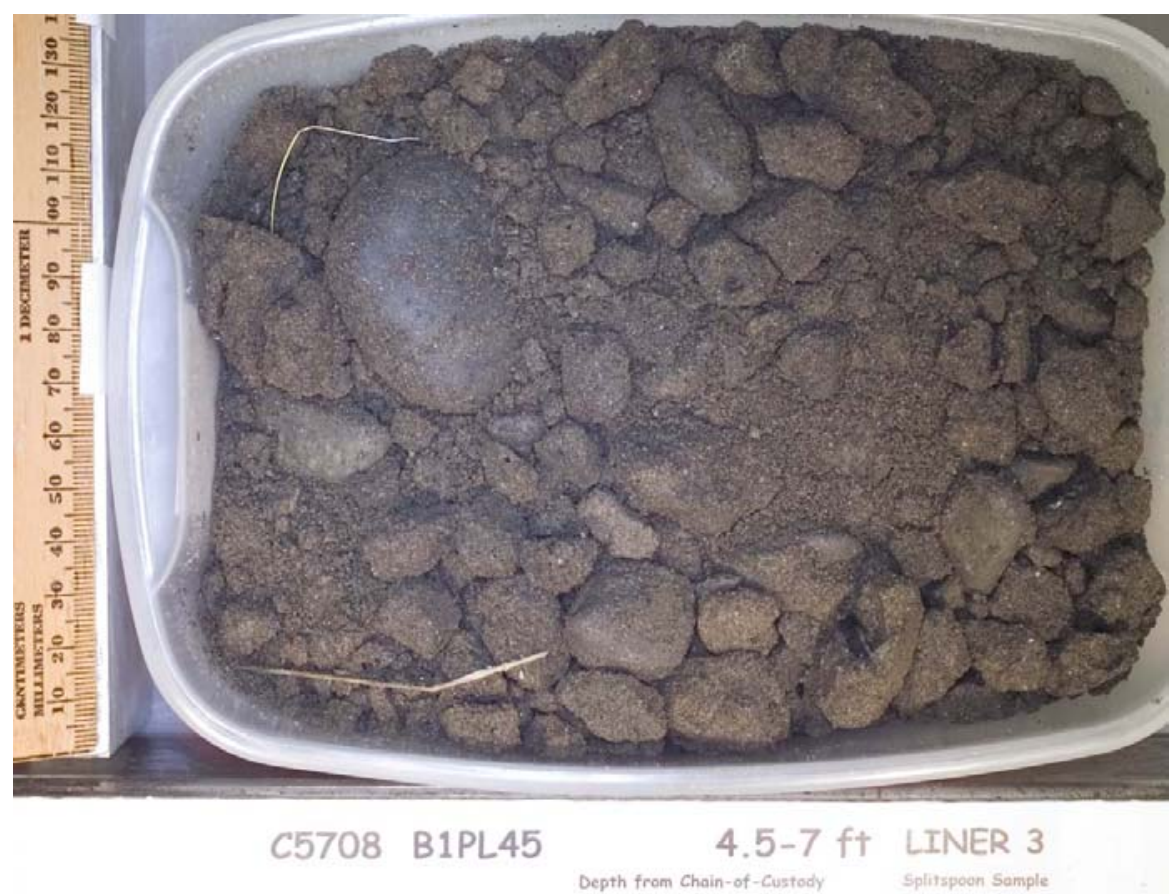

Figure C.2. Photograph of Liner 3 from Sample B1PL45 (Borehole 399-2-5) 


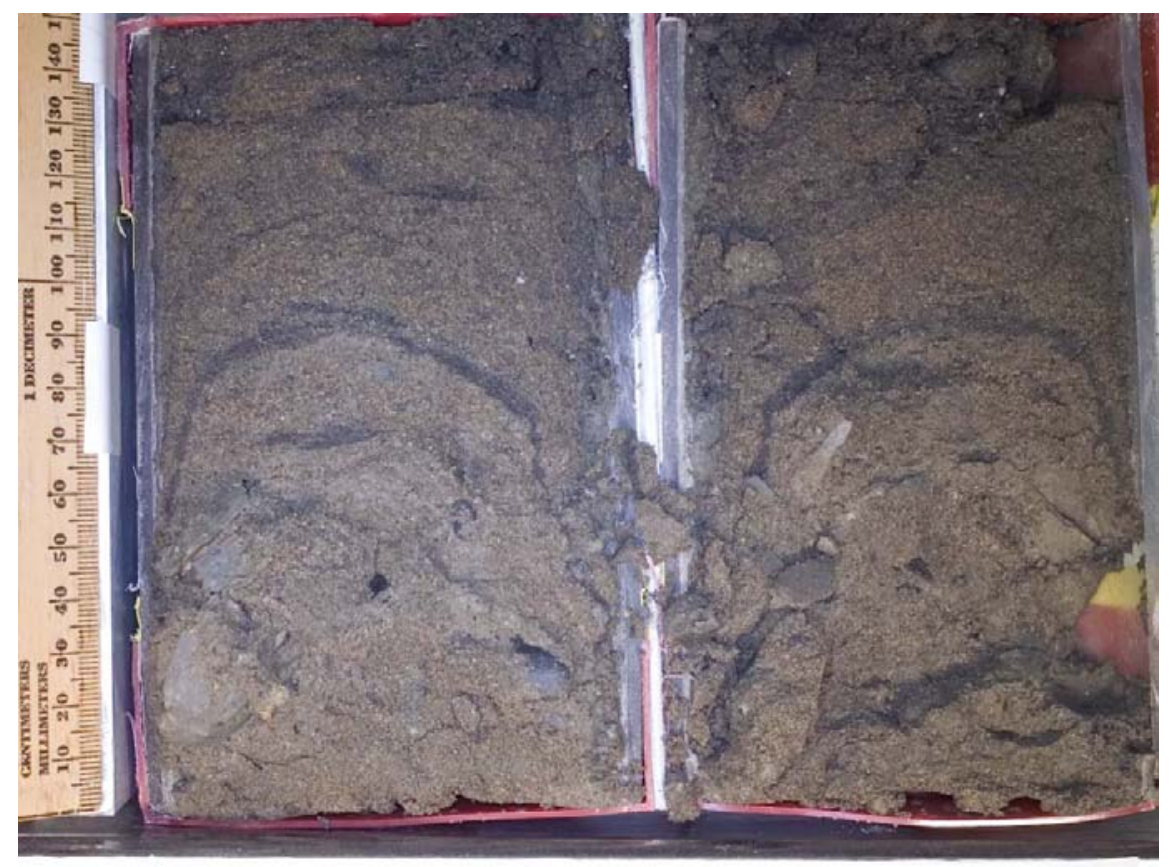

C5708 B1PL45

4.5-7 ft LINER 2 UP $\uparrow$

Depth from Chain-of-Custod

spilitspoon somp

Figure C.3. Photograph of Liner 2 from Sample B1PL45 (Borehole 399-2-5)

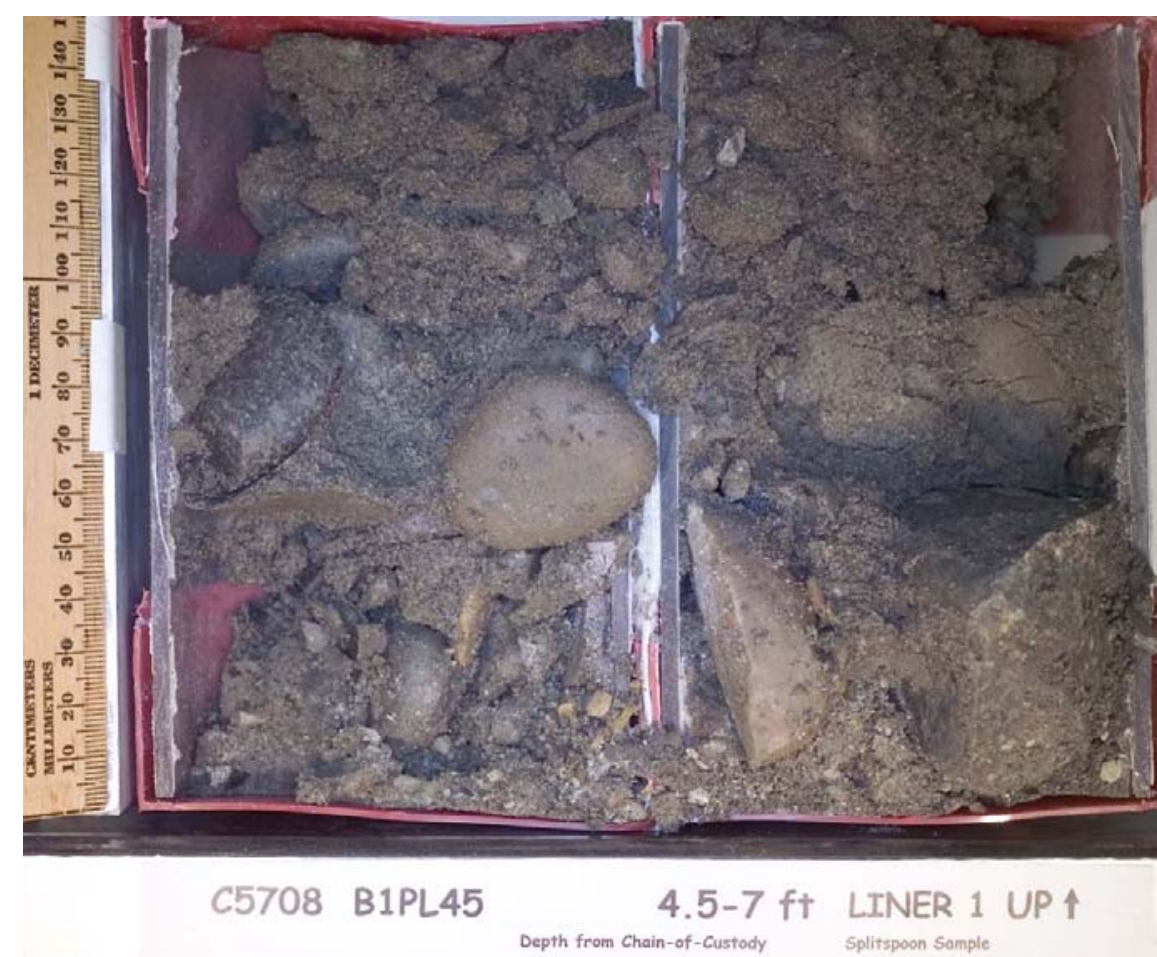

Figure C.4. Photograph of Liner 1 from Sample B1PL45 (Borehole 399-2-5) 


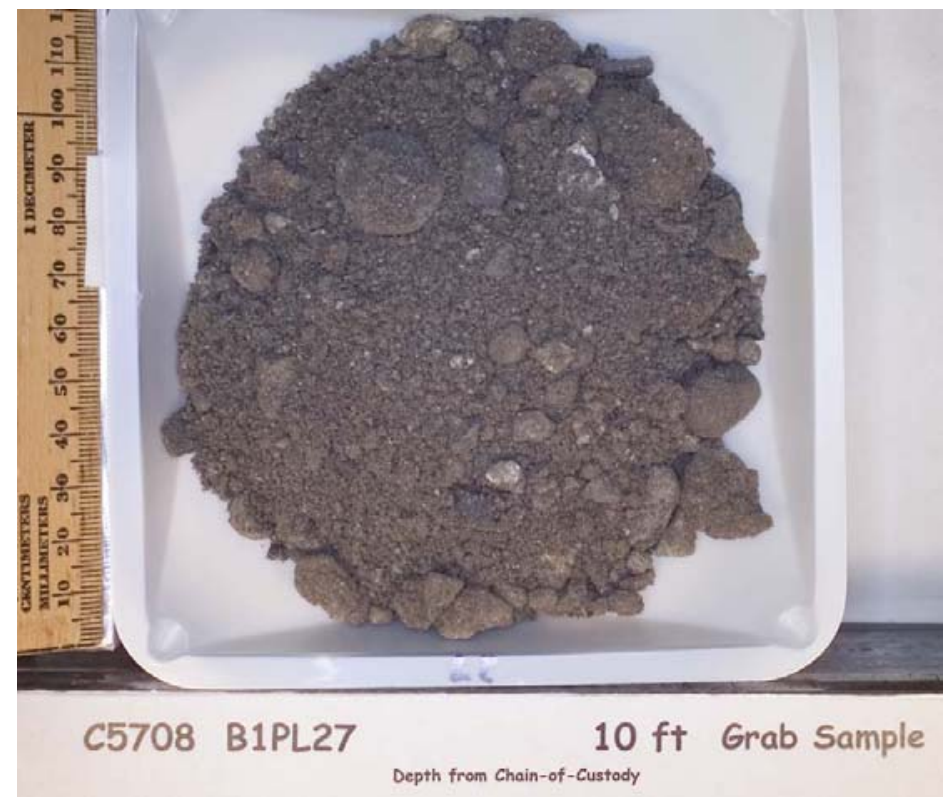

Figure C.5. Photograph of Grab Sample B1PL27 from Borehole 399-2-5

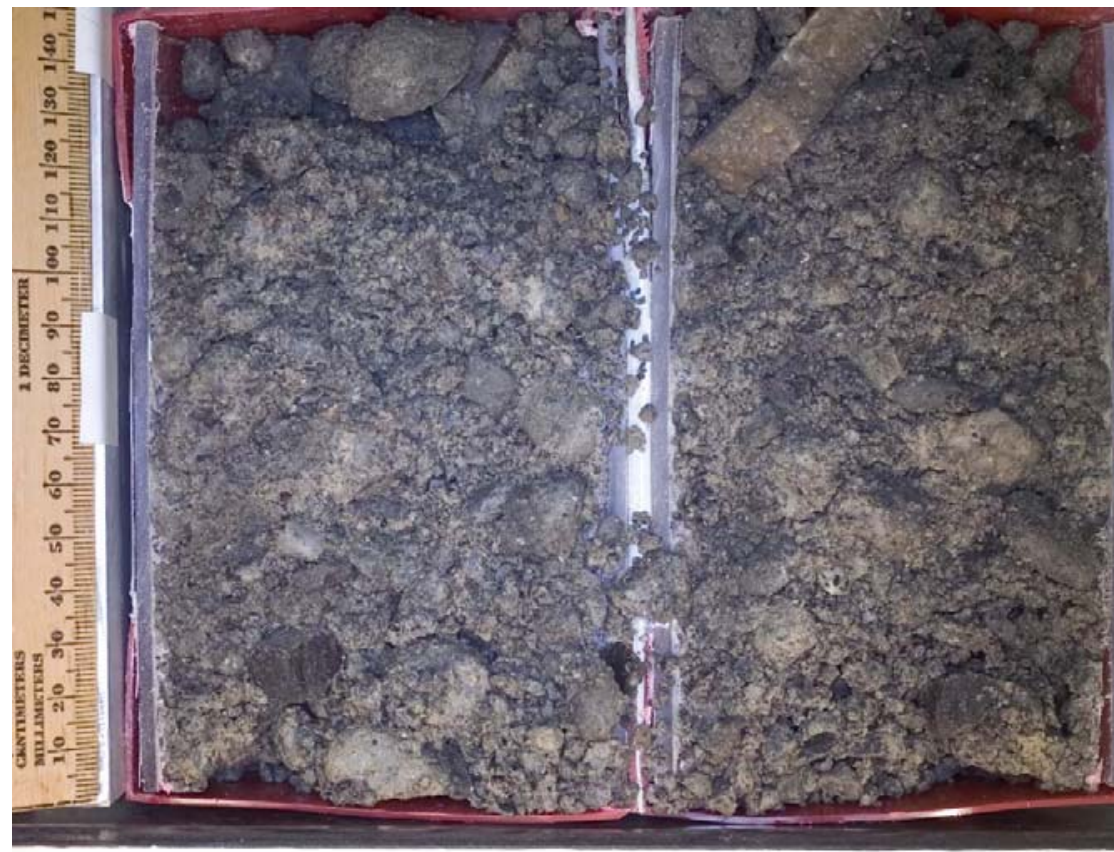

C5708 B1PL46

15-17 ft LINER 4 UP 1

Depth from Chain-of-Custody Splitspoon Samplc

Figure C.6. Photograph of Liner 4 from Sample B1PL46 (Borehole 399-2-5) 


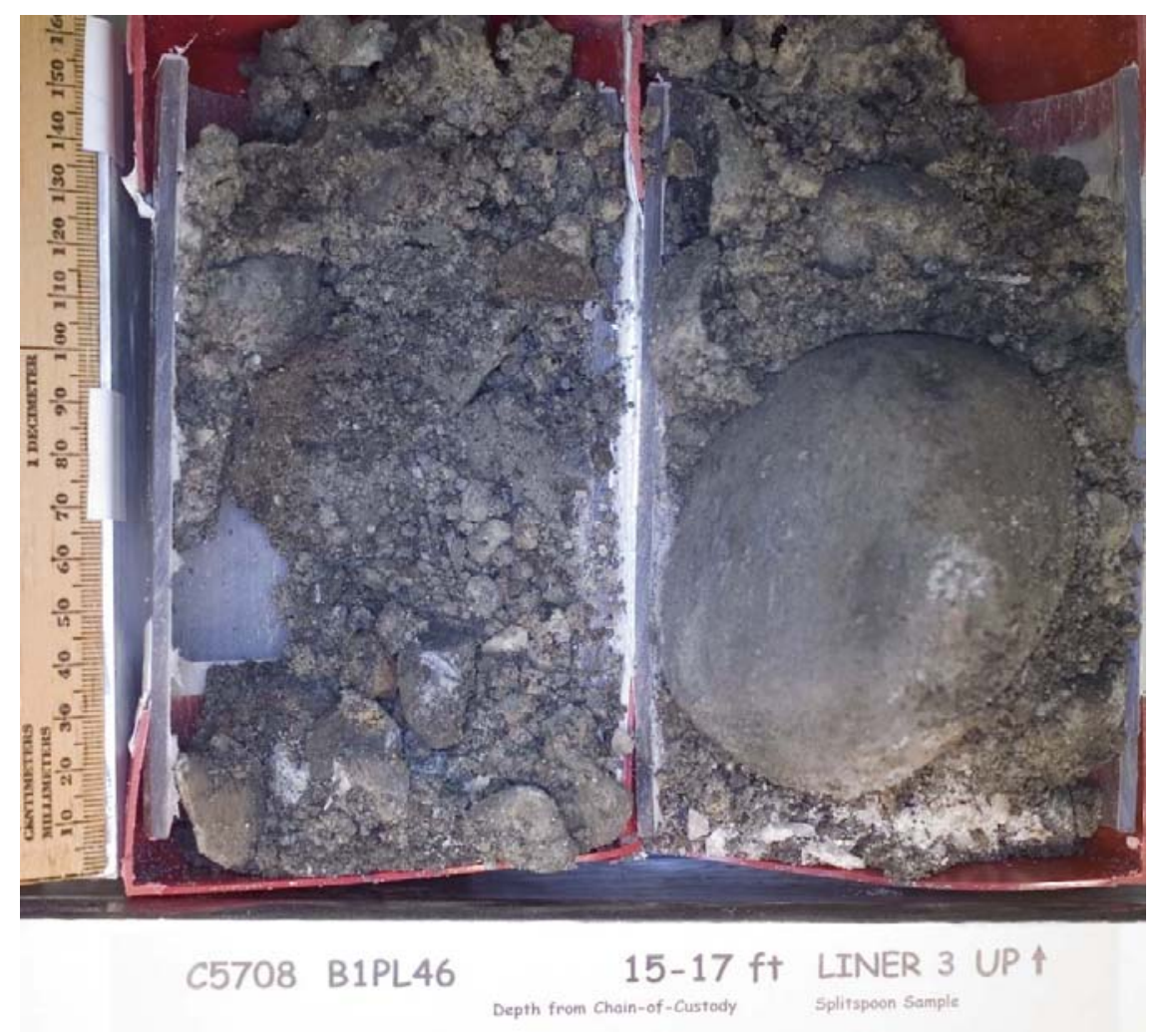

Figure C.7. Photograph of Liner 3 from Sample B1PL46 (Borehole 399-2-5)

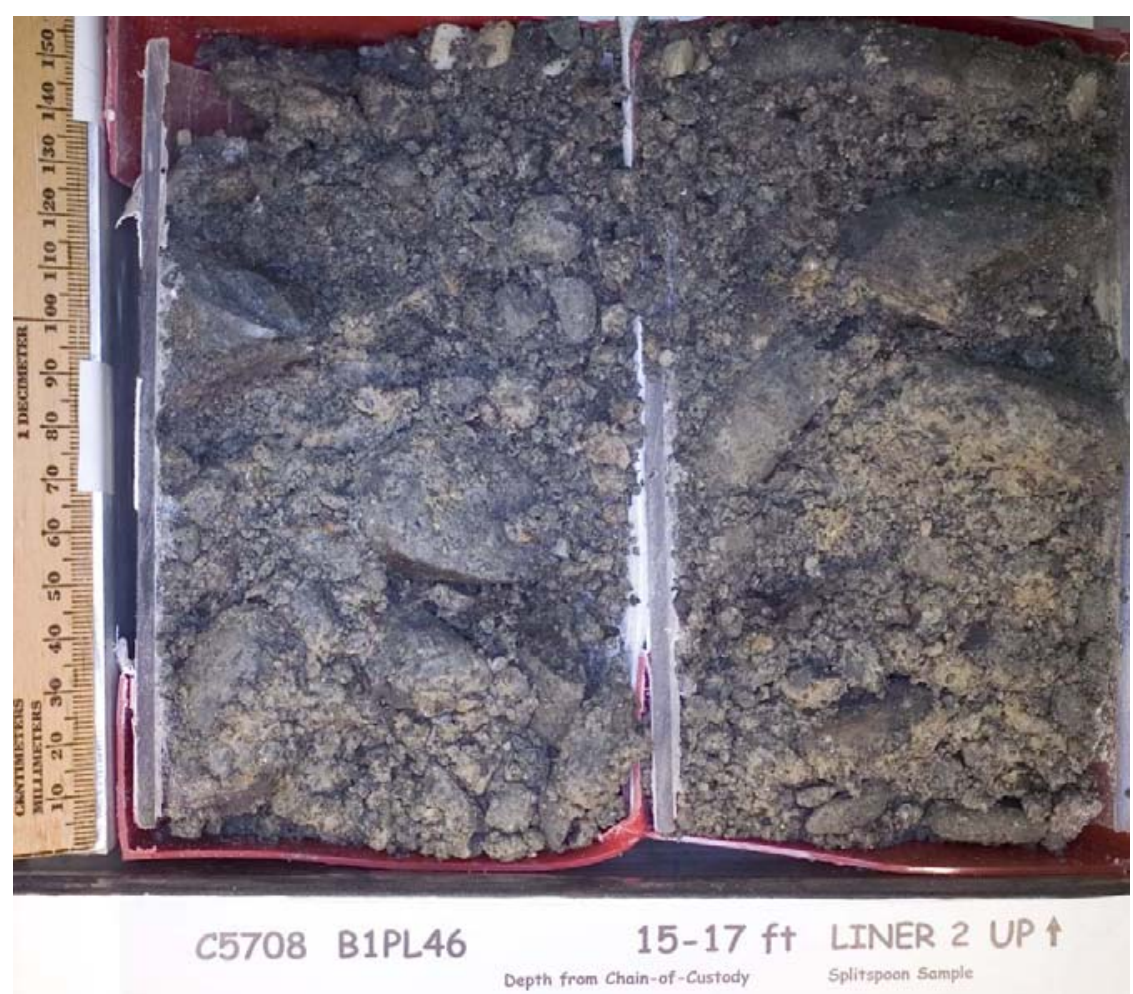

Figure C.8. Photograph of Liner 2 from Sample B1PL46 (Borehole 399-2-5) 


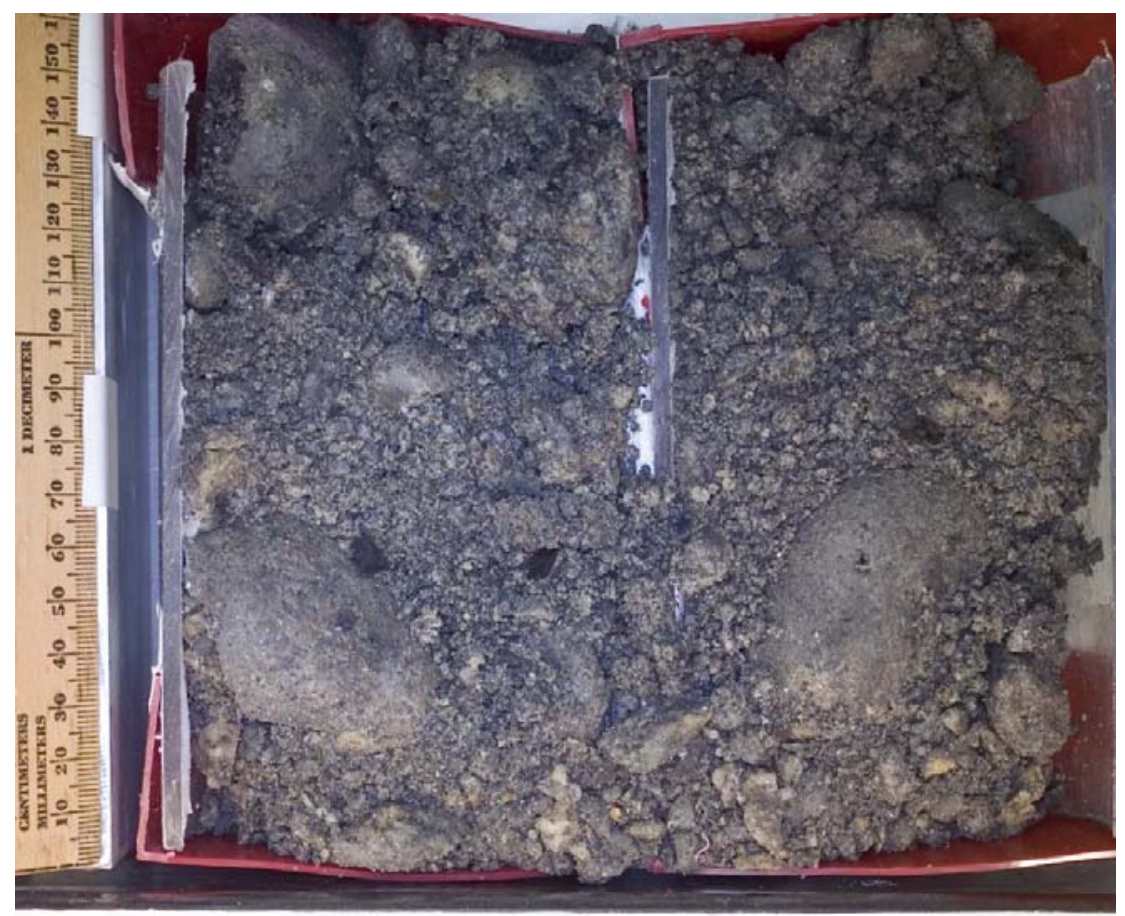

$$
\text { C5708 B1PL46 } \begin{gathered}
15-17 \mathrm{ft} \\
\text { Depth from Chain-of-Custody }
\end{gathered}
$$

Figure C.9. Photograph of Liner 1 from Sample B1PL46 (Borehole 399-2-5)

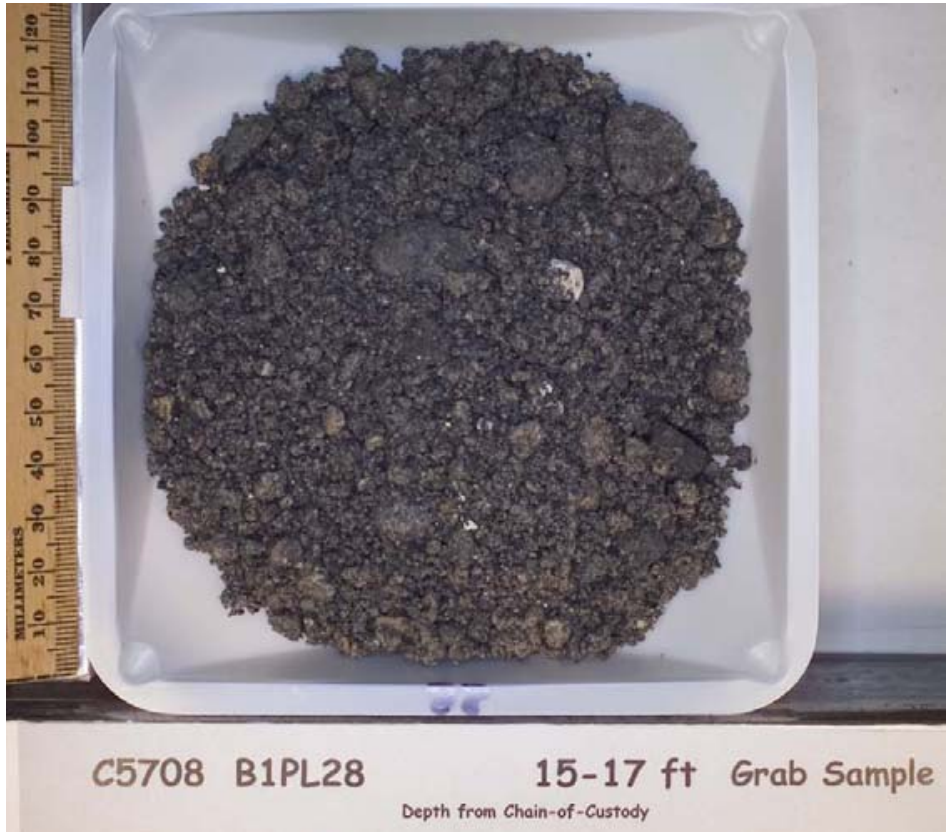

Figure C.10. Photograph of Grab Sample B1PL28 from Borehole 399-2-5 


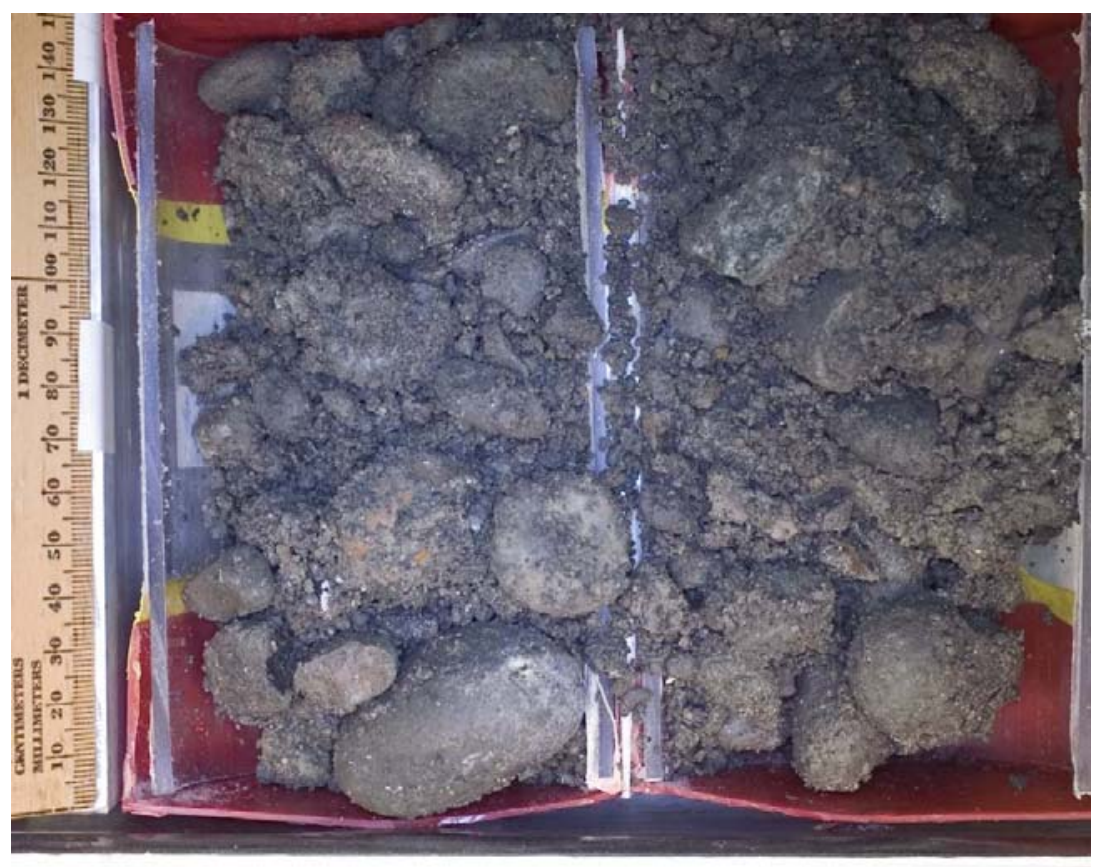

C5708 B1PL47

20-22.5 ft LINER 3 UP $\uparrow$

Depth from Chain-of-Custody splitspoon Sample

Figure C.11. Photograph of Liner 3 from Sample B1PL47 from Borehole 399-2-5

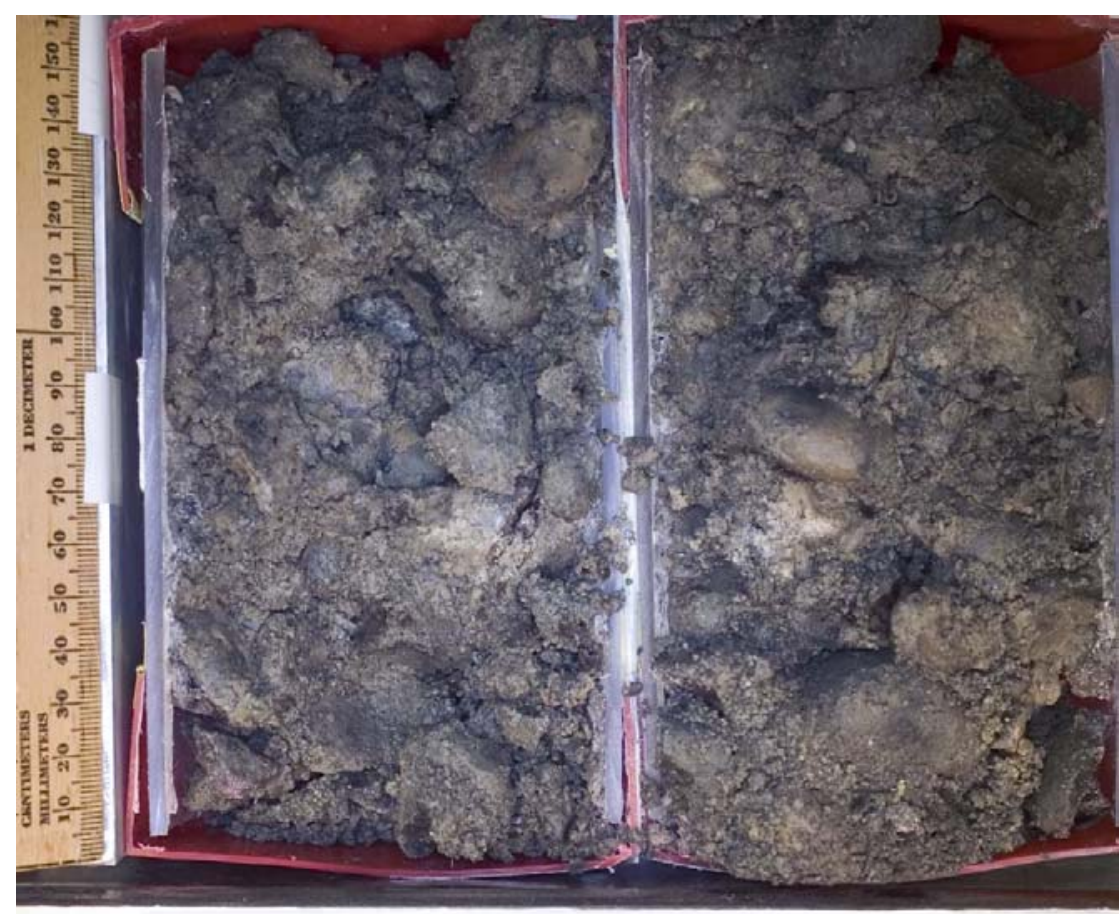

C5708 B1PL47 20-22.5 ft LINER 2 UP $\uparrow$

Figure C.12. Photograph of Liner 2 from Sample B1PL47 from Borehole 399-2-5 


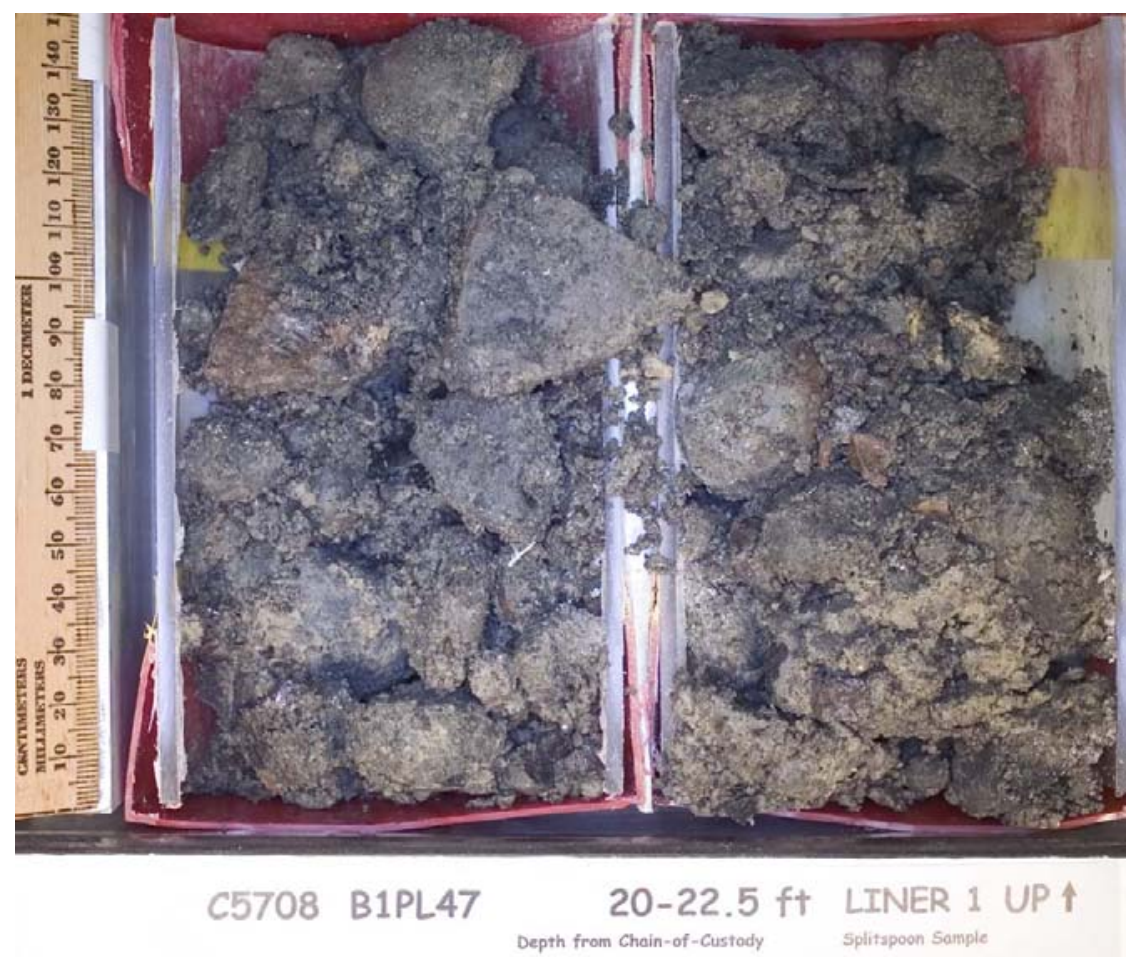

Figure C.13. Photograph of Liner 1 from Sample B1PL47 from Borehole 399-2-5

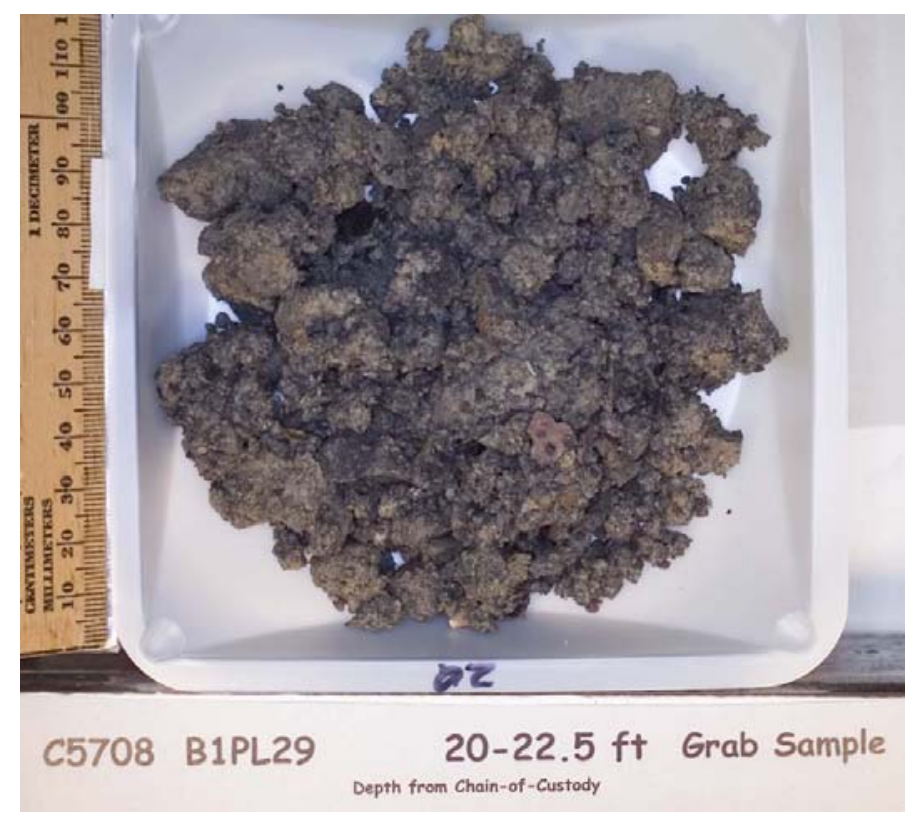

Figure C.14. Photograph of Grab Sample B1PL29 from Borehole 399-2-5 


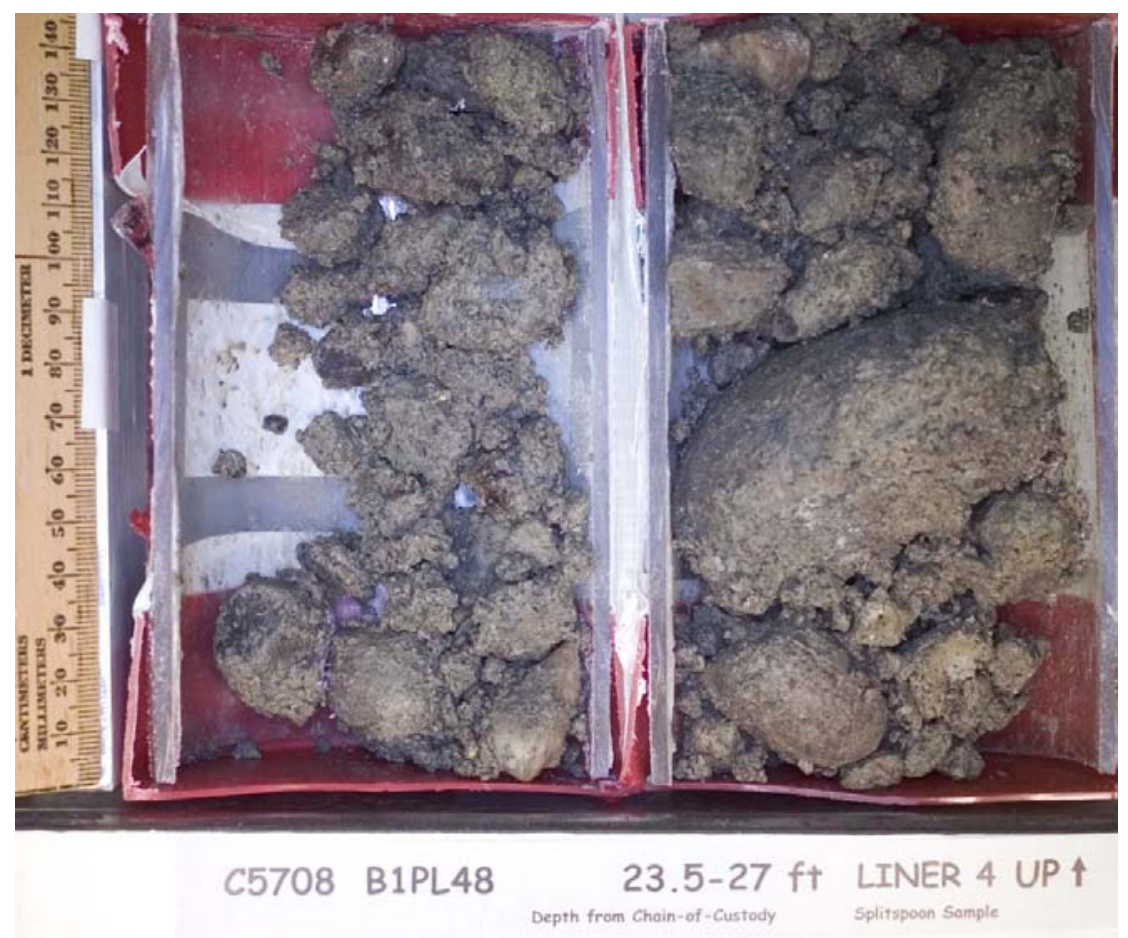

Figure C.15. Photograph of Liner 4 from Sample B1PL48 from Borehole 399-2-5

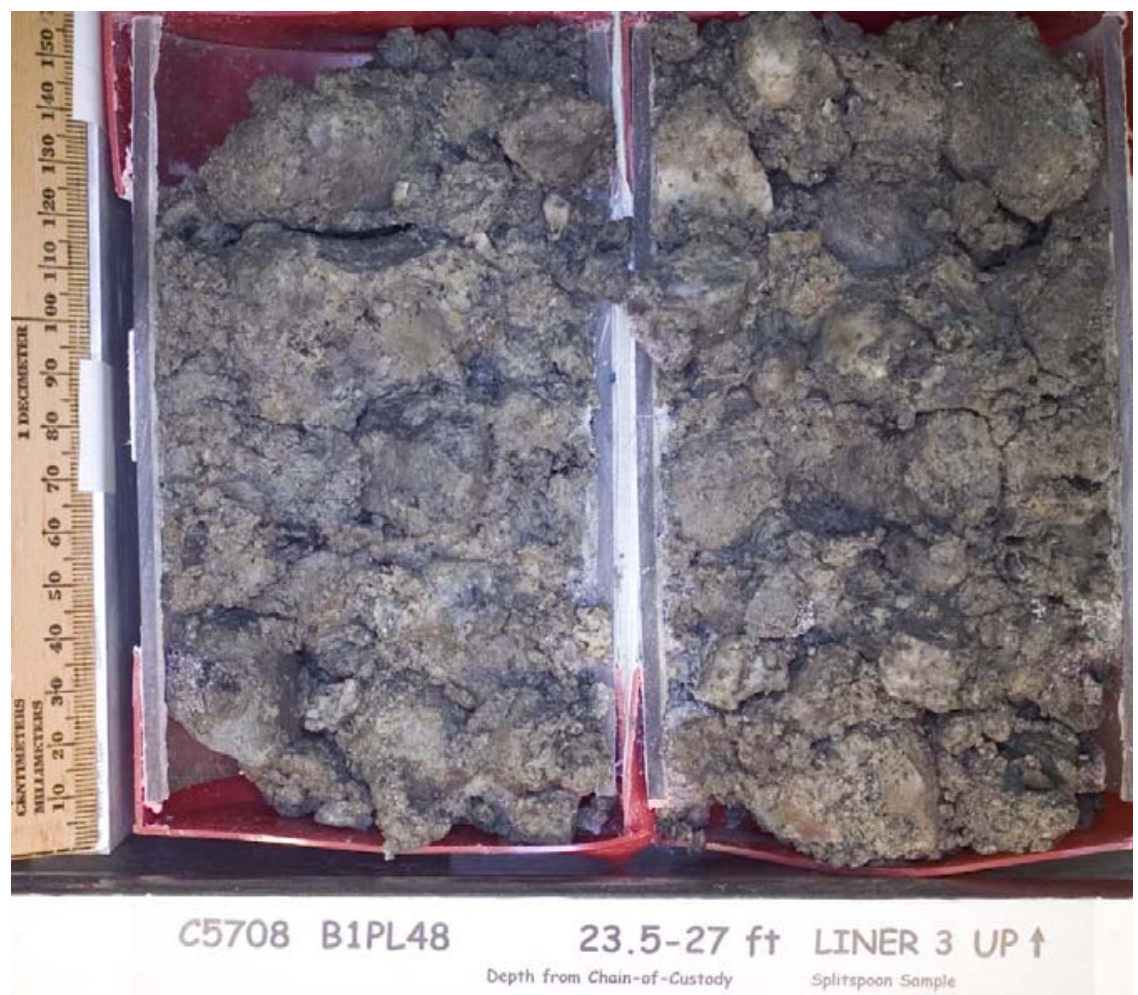

Figure C.16. Photograph of Liner 3 from Sample B1PL48 from Borehole 399-2-5 


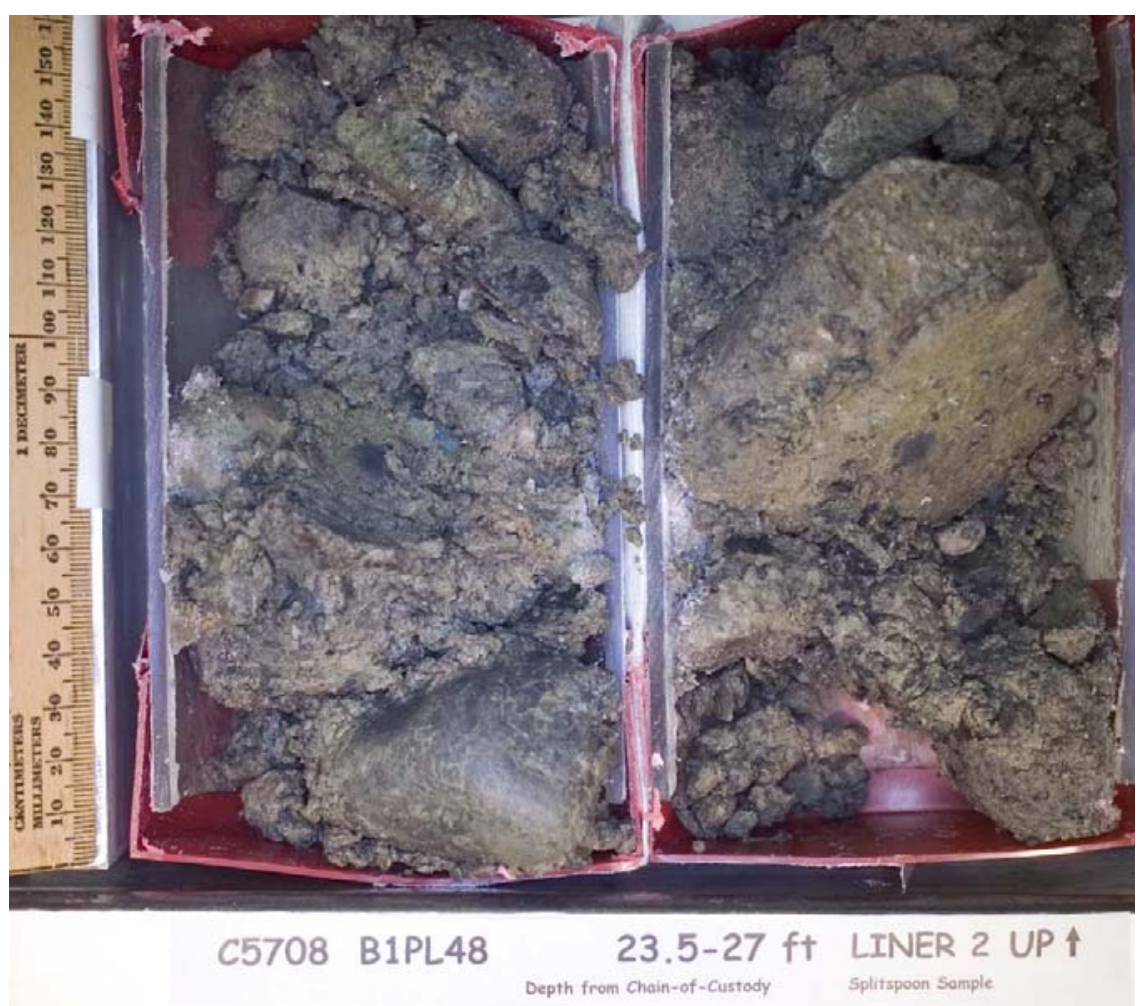

Figure C.17. Photograph of Liner 2 from Sample B1PL48 from Borehole 399-2-5

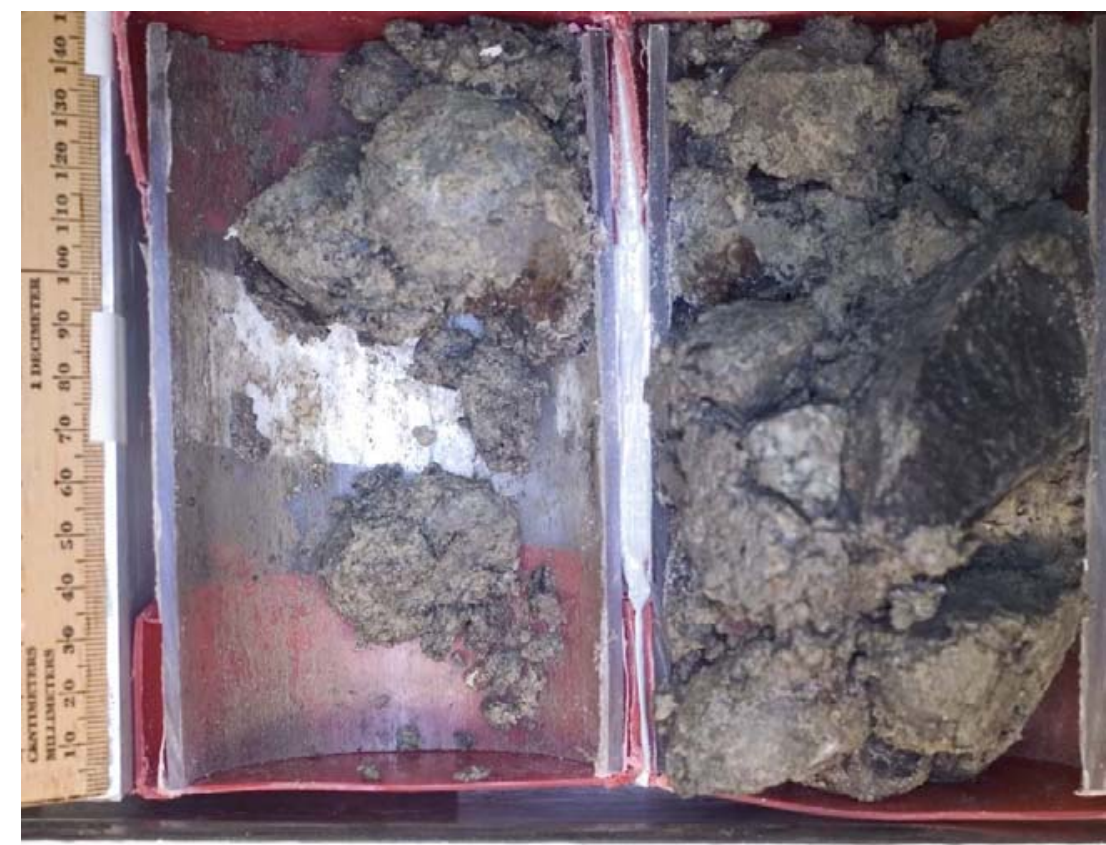

C5708 B1PL48

23.5-27 ft LINER 1 UP $\uparrow$

Figure C.18. Photograph of Liner 1 from Sample B1PL48 from Borehole 399-2-5 


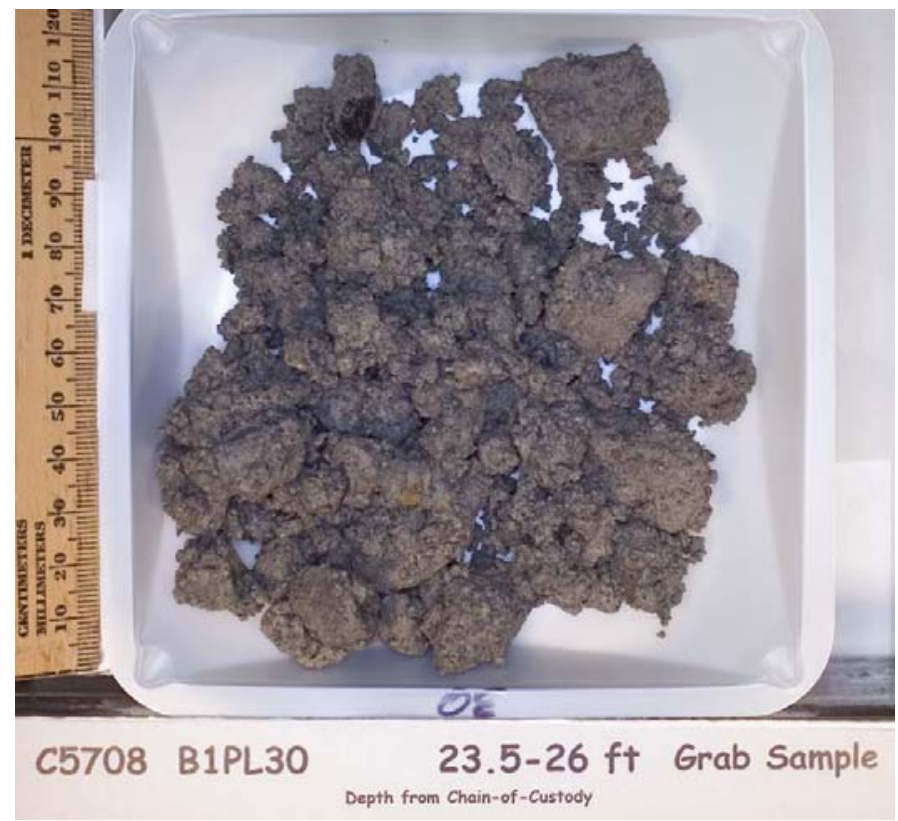

Figure C.19. Photograph of Grab Sample B1PL30 from Borehole 399-2-5

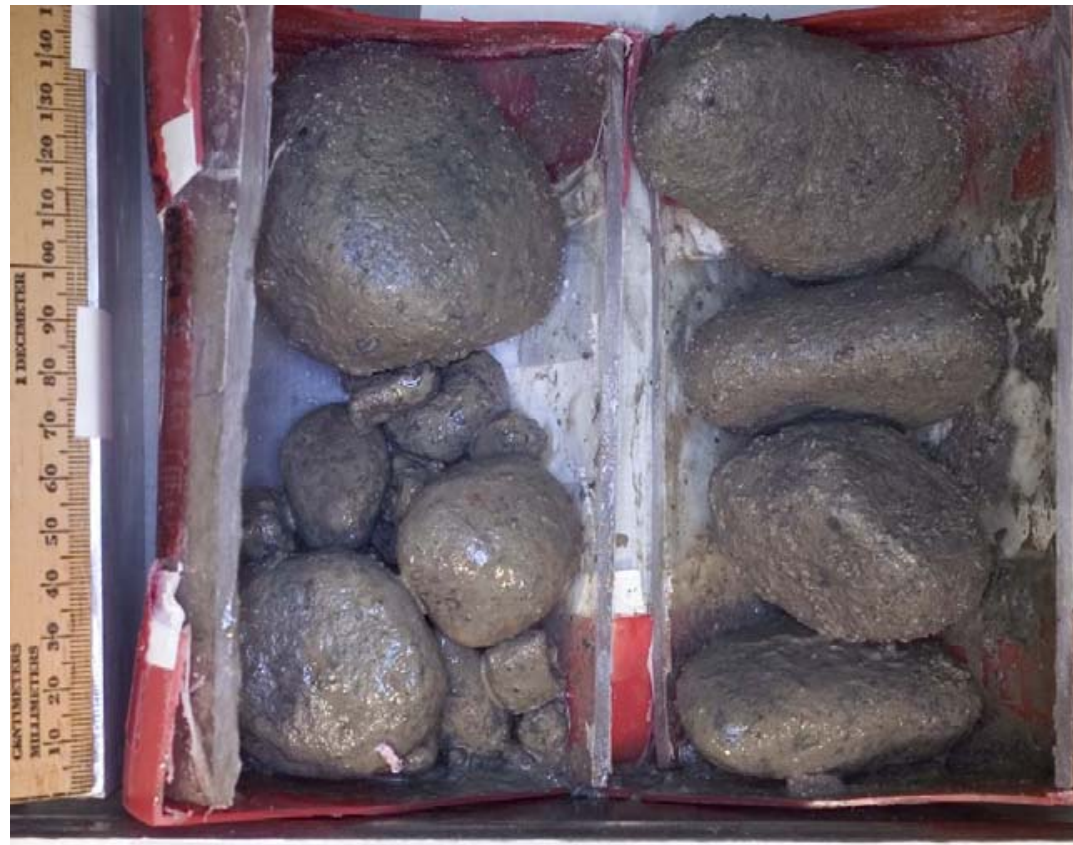

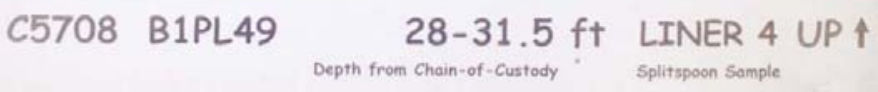

Figure C.20. Photograph of Liner 4 from Sample B1PL49 from Borehole 399-2-5 


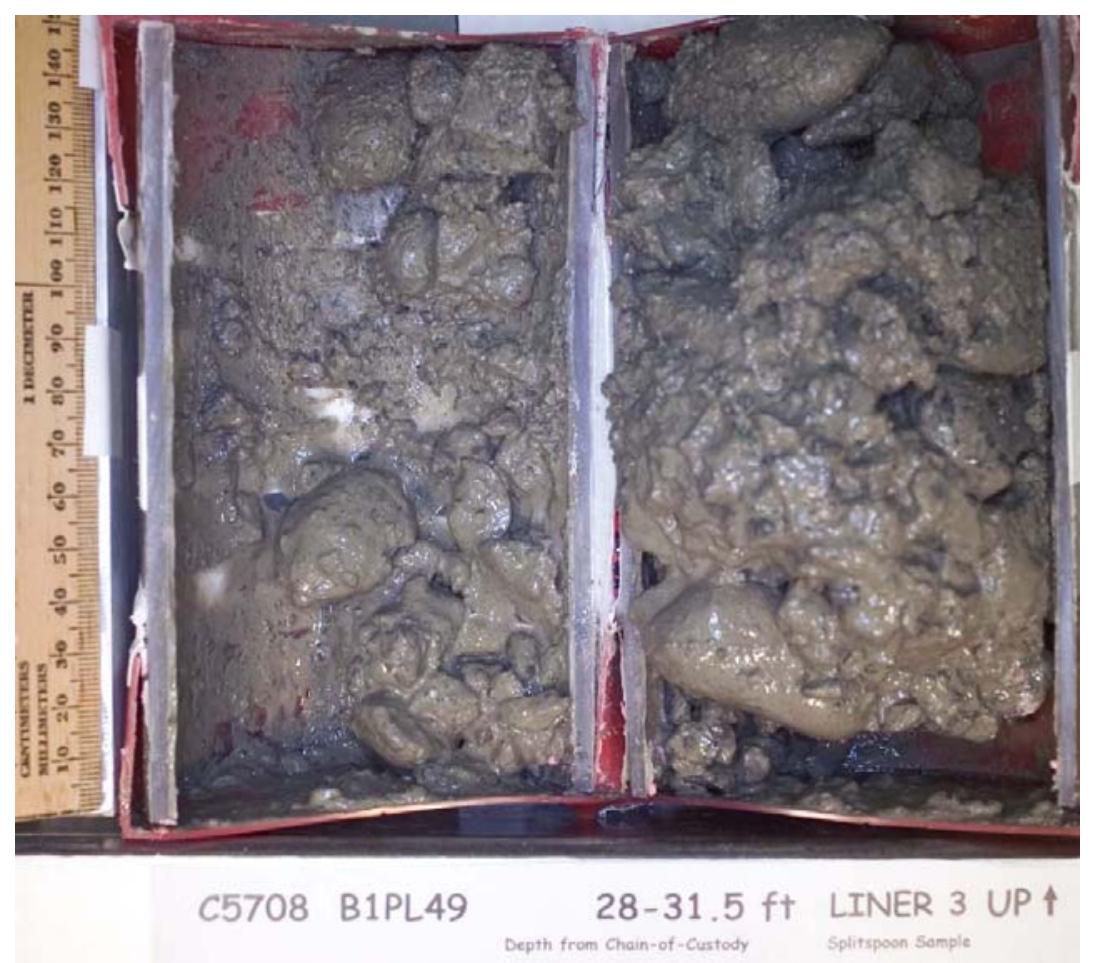

Figure C.21. Photograph of Liner 3 from Sample B1PL49 from Borehole 399-2-5

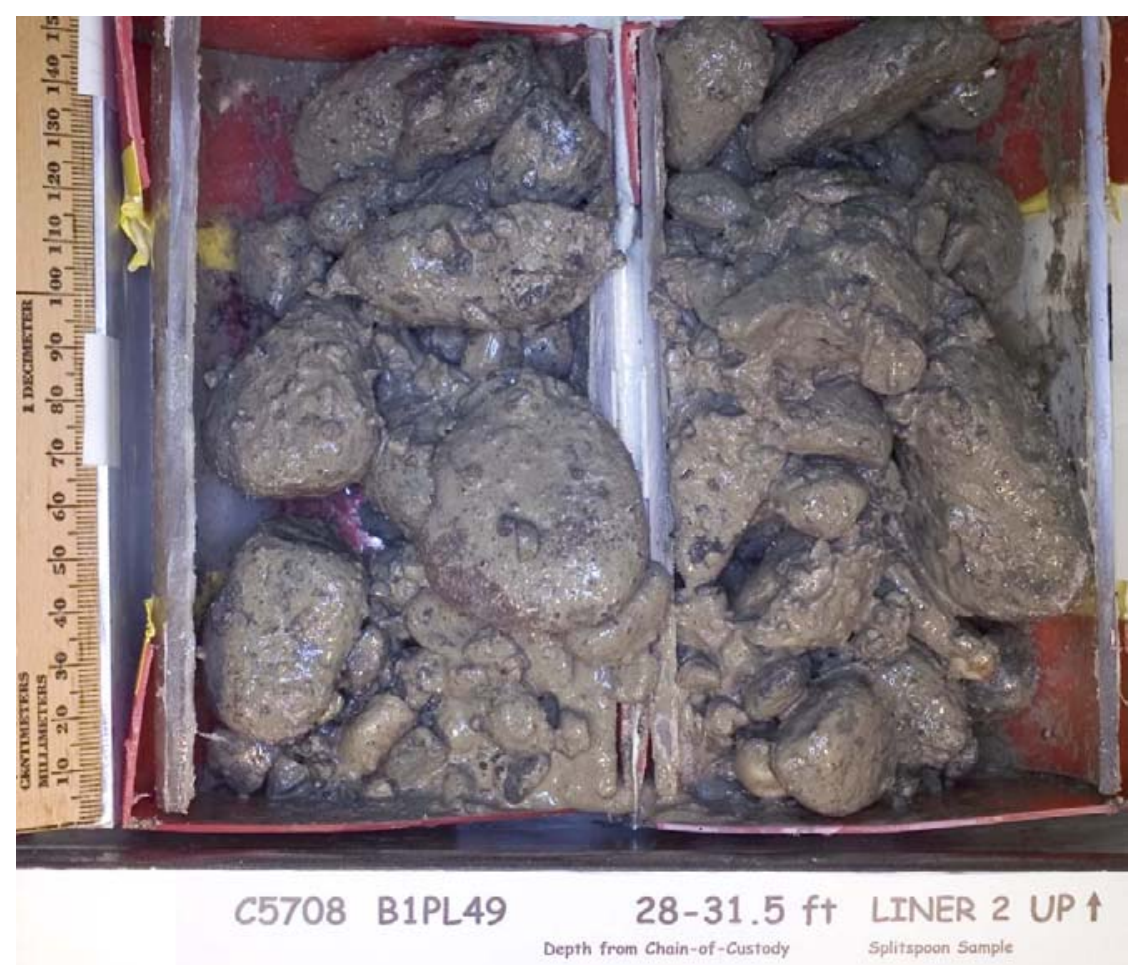

Figure C.22. Photograph of Liner 2 from Sample B1PL49 from Borehole 399-2-5 


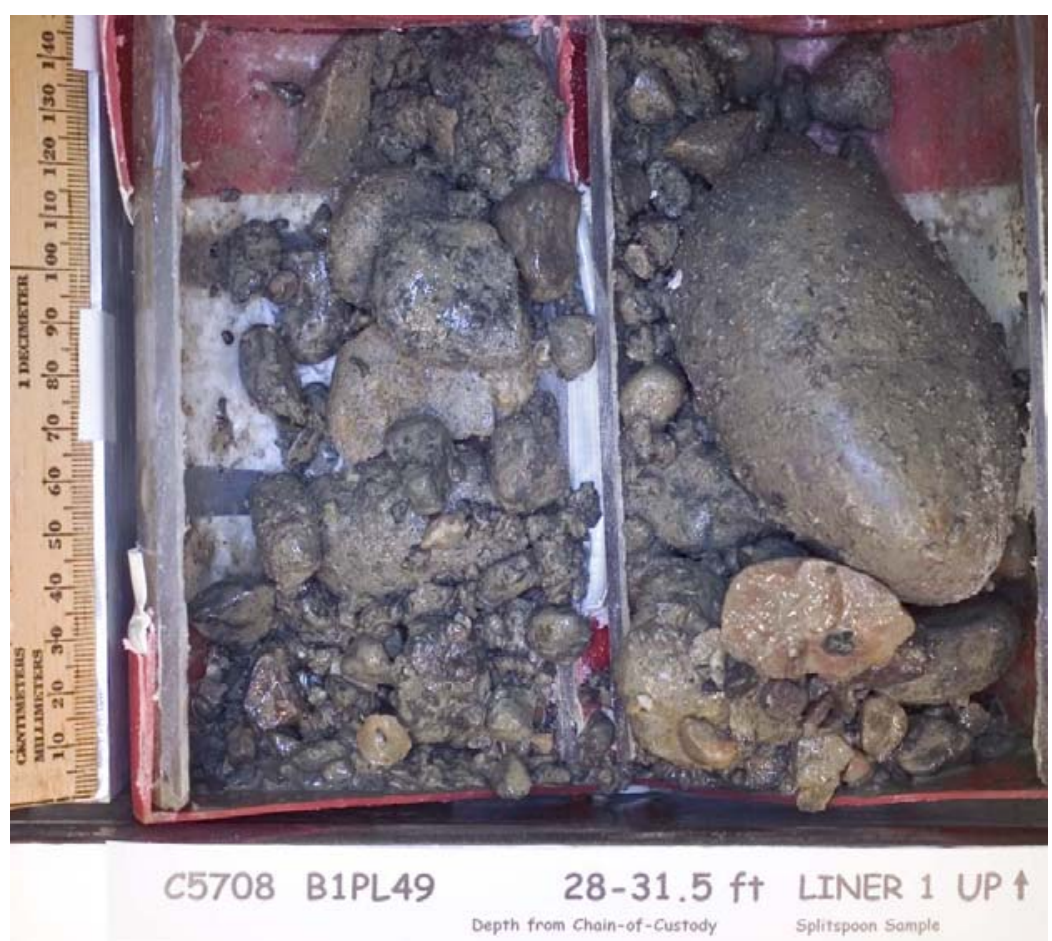

Figure C.23. Photograph of Liner 1 from Sample B1PL49 from Borehole 399-2-5

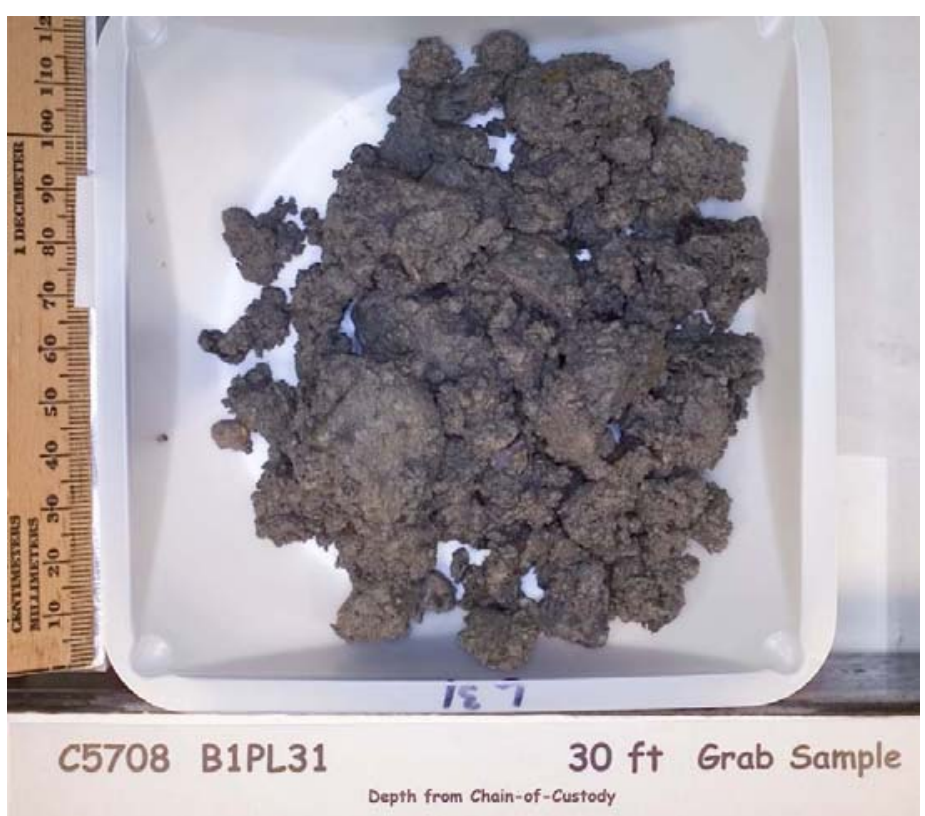

Figure C.24. Photograph of Grab Sample B1PL31 from Borehole 399-2-5 


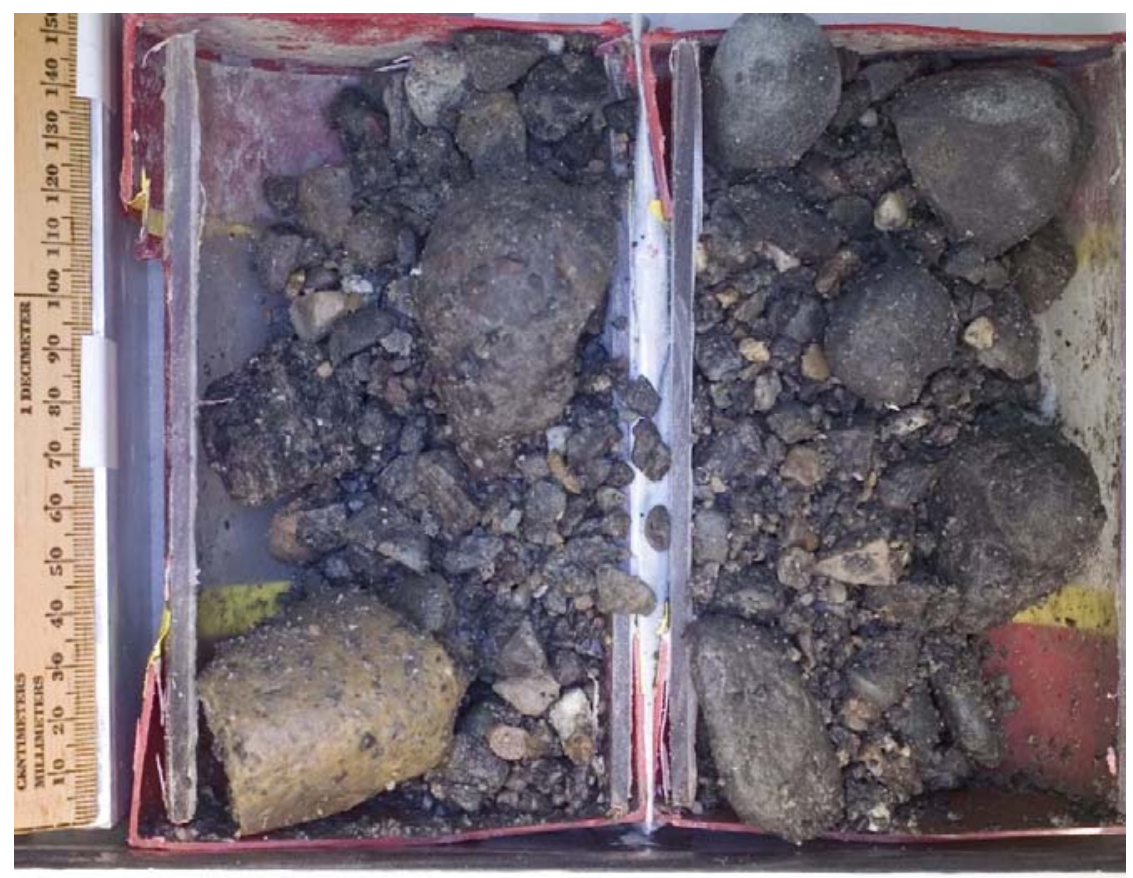

$$
\text { C5708 B1PL50 } \begin{aligned}
& 33.8-36.8 \mathrm{ft} \\
& \text { LINER } 3 \text { UP } \uparrow
\end{aligned}
$$

Figure C.25. Photograph of Liner 3 from Sample B1PL50 from Borehole 399-2-5

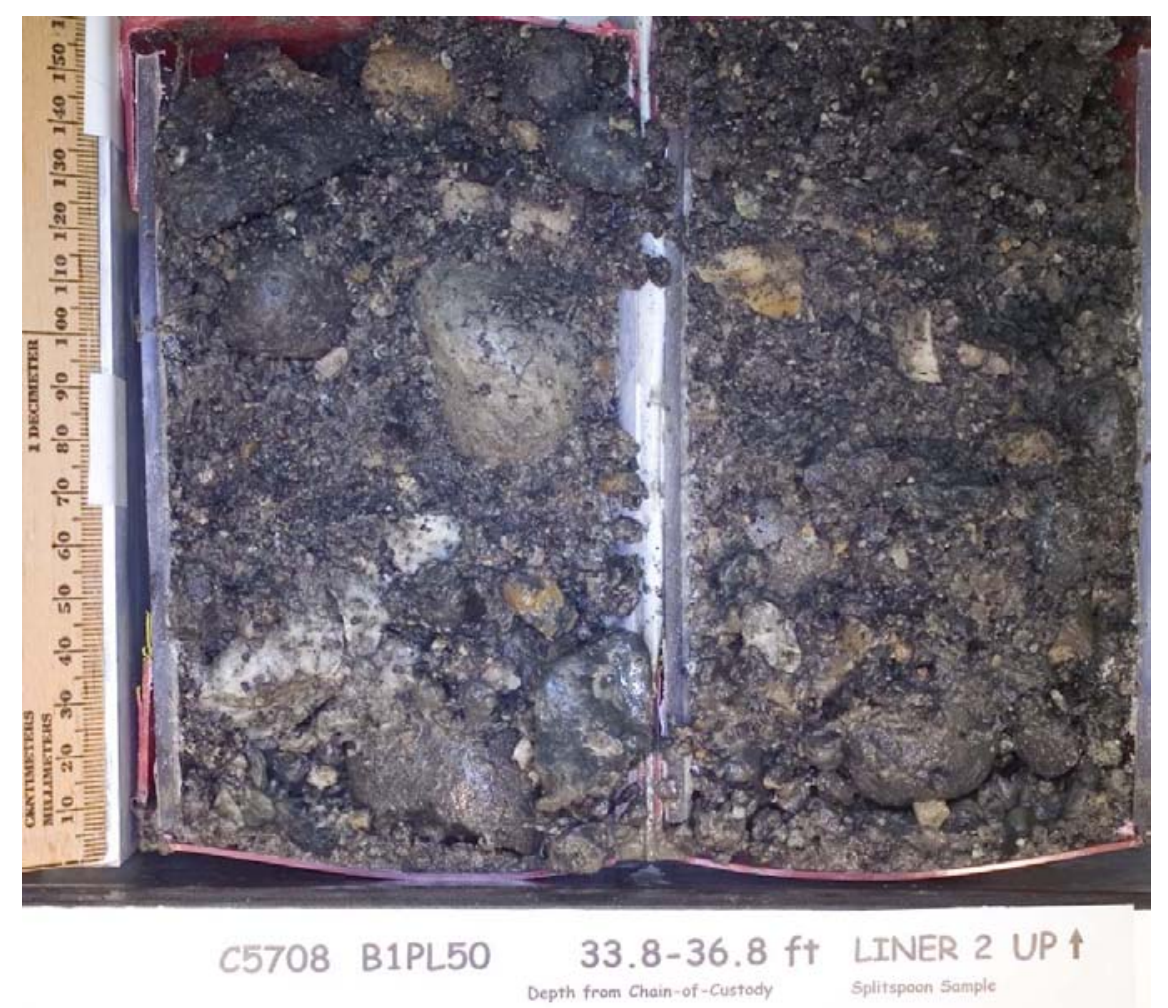

Figure C.26. Photograph of Liner 2 from Sample B1PL50 from Borehole 399-2-5 

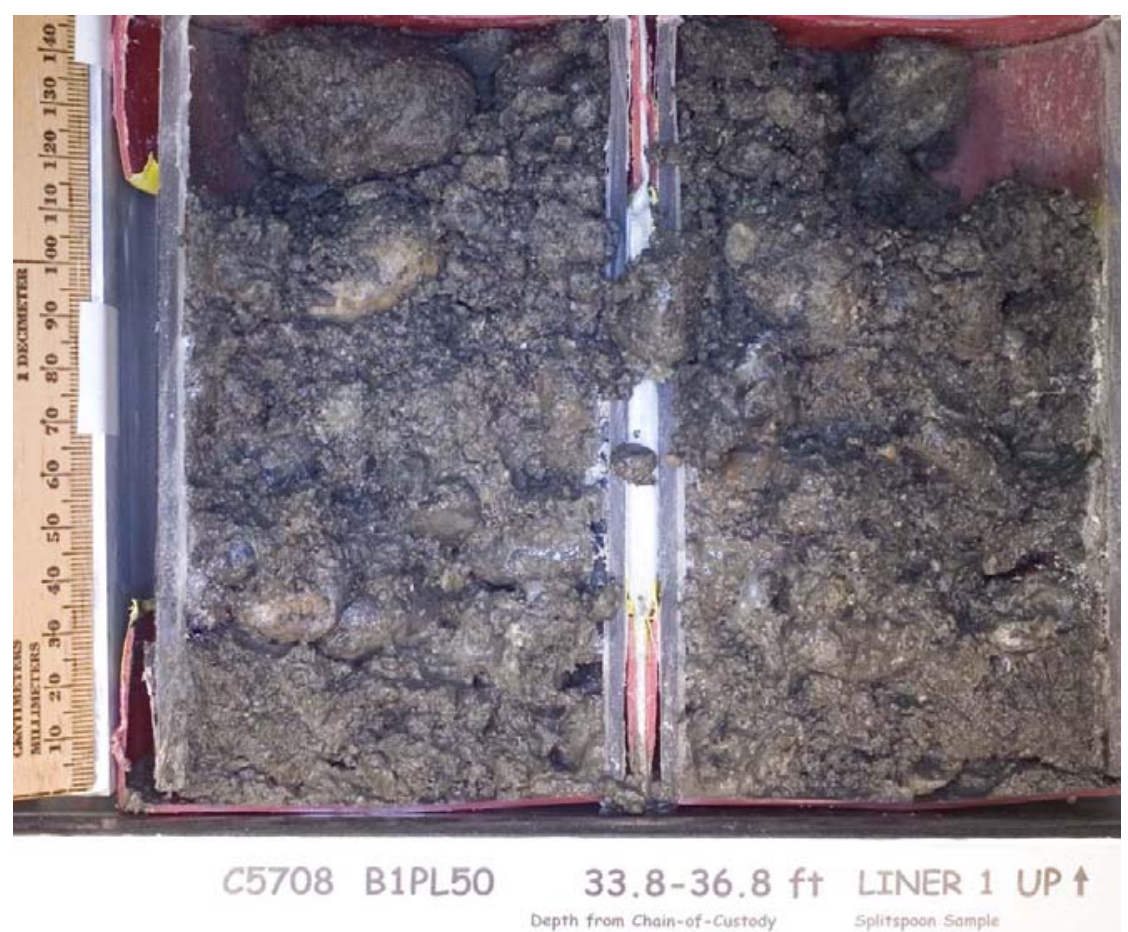

Figure C.27. Photograph of Liner 1 from Sample B1PL50 from Borehole 399-2-5

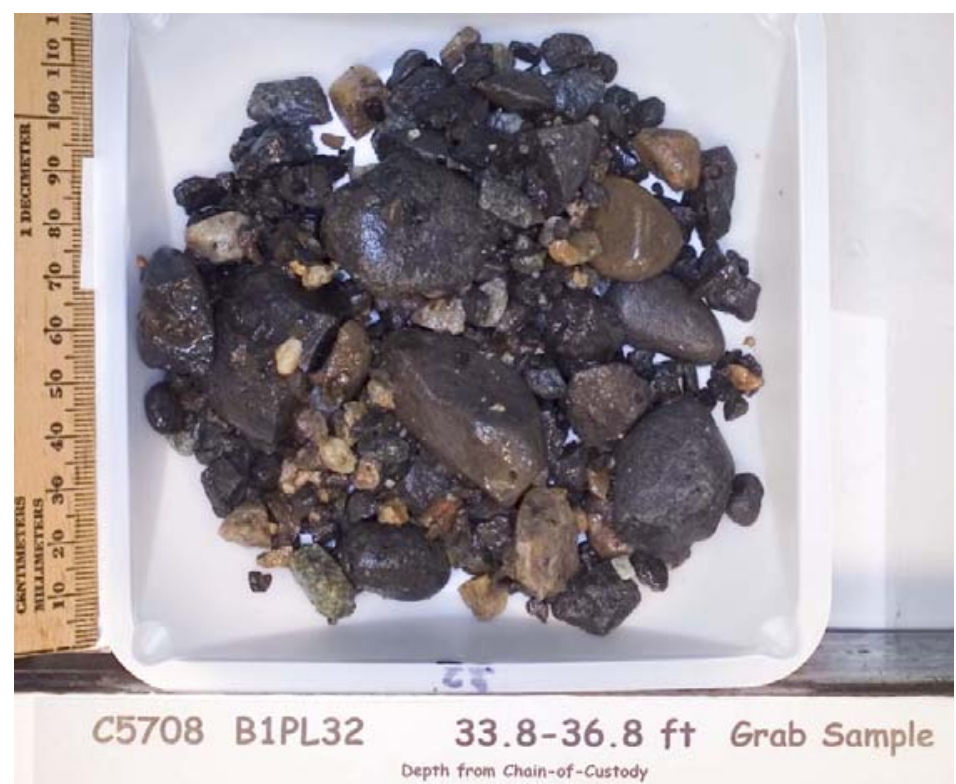

Figure C.28. Photograph of Grab Sample B1PL32 from Borehole 399-2-5 


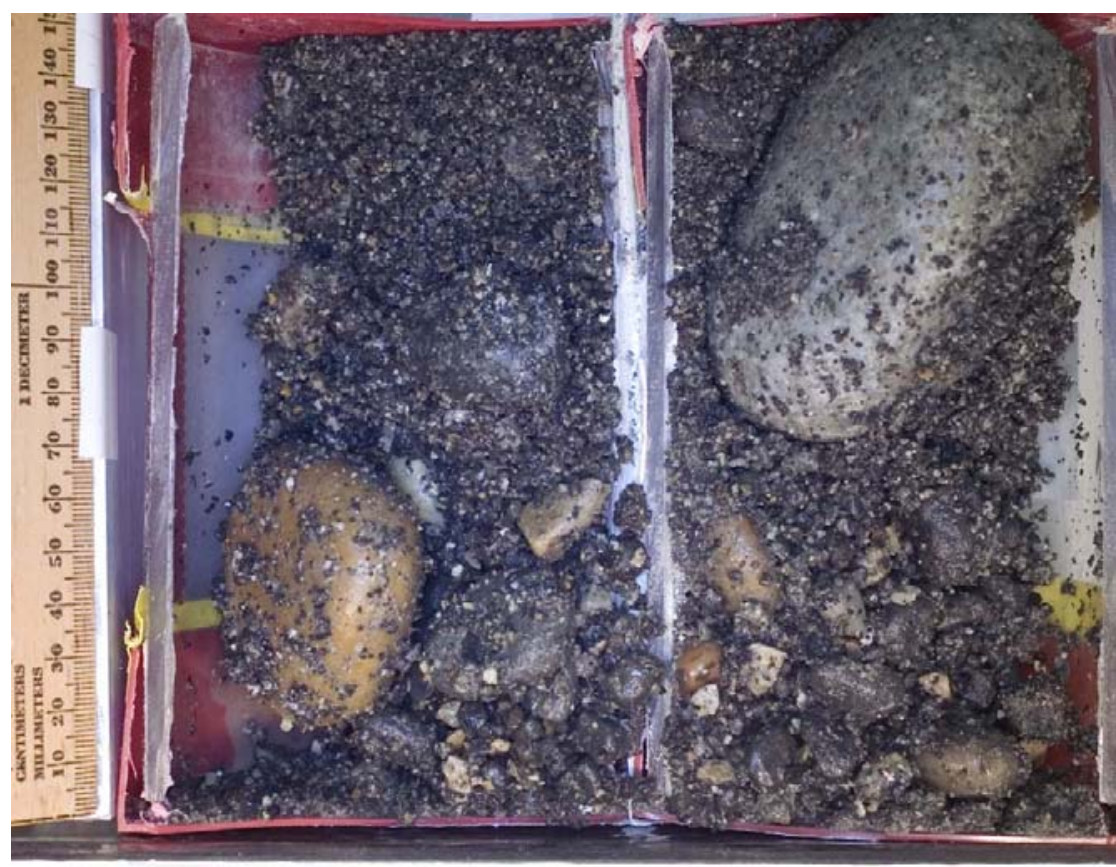

$$
\text { C5708 B1PL51 } 40.8-43.8 \mathrm{ft} \text { LINER } 3 \text { UP } \uparrow
$$

Figure C.29. Photograph of Liner 3 from Sample B1PL51 from Borehole 399-2-5

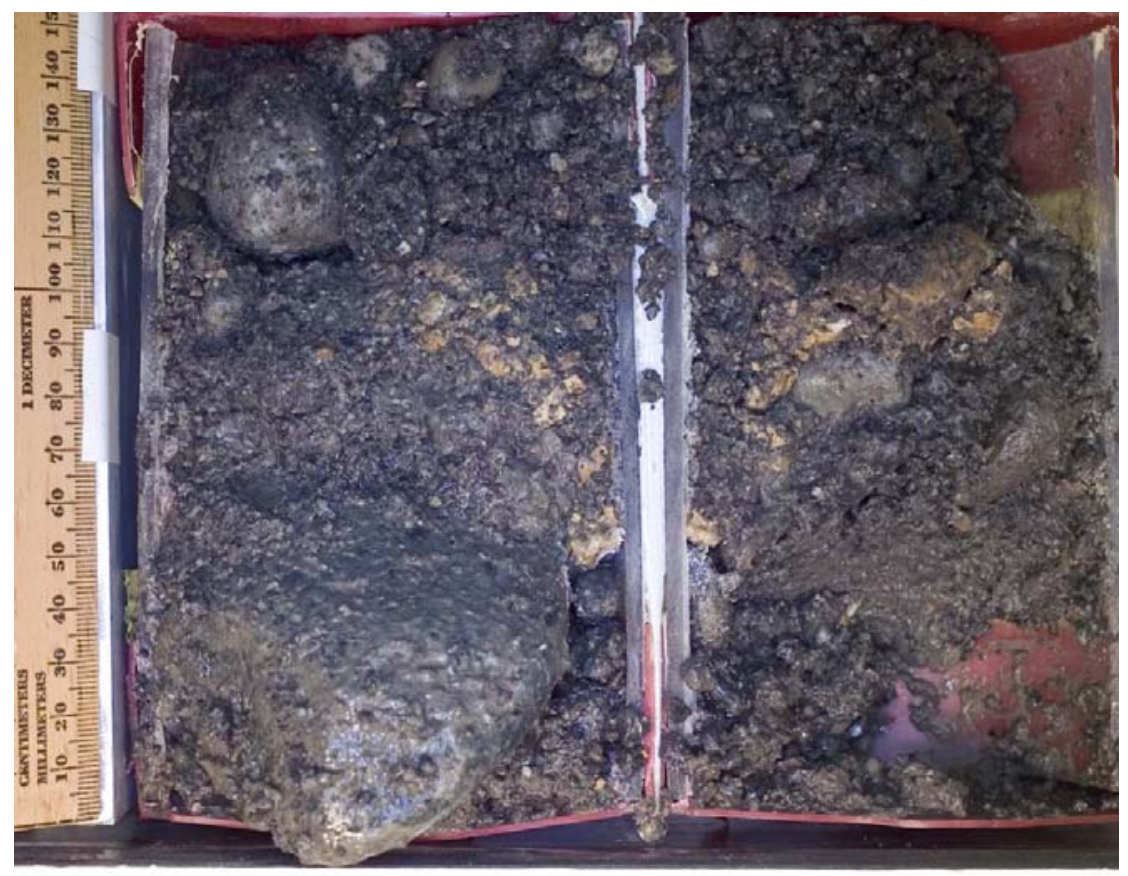

$$
\text { C5708 B1PL51 } \begin{gathered}
40.8-43.8 \\
\text { Depth from Chain-of-Custody }
\end{gathered} \text { LINER } 2 \text { UP } \uparrow
$$

Figure C.30. Photograph of Liner 2 from Sample B1PL51 from Borehole 399-2-5 


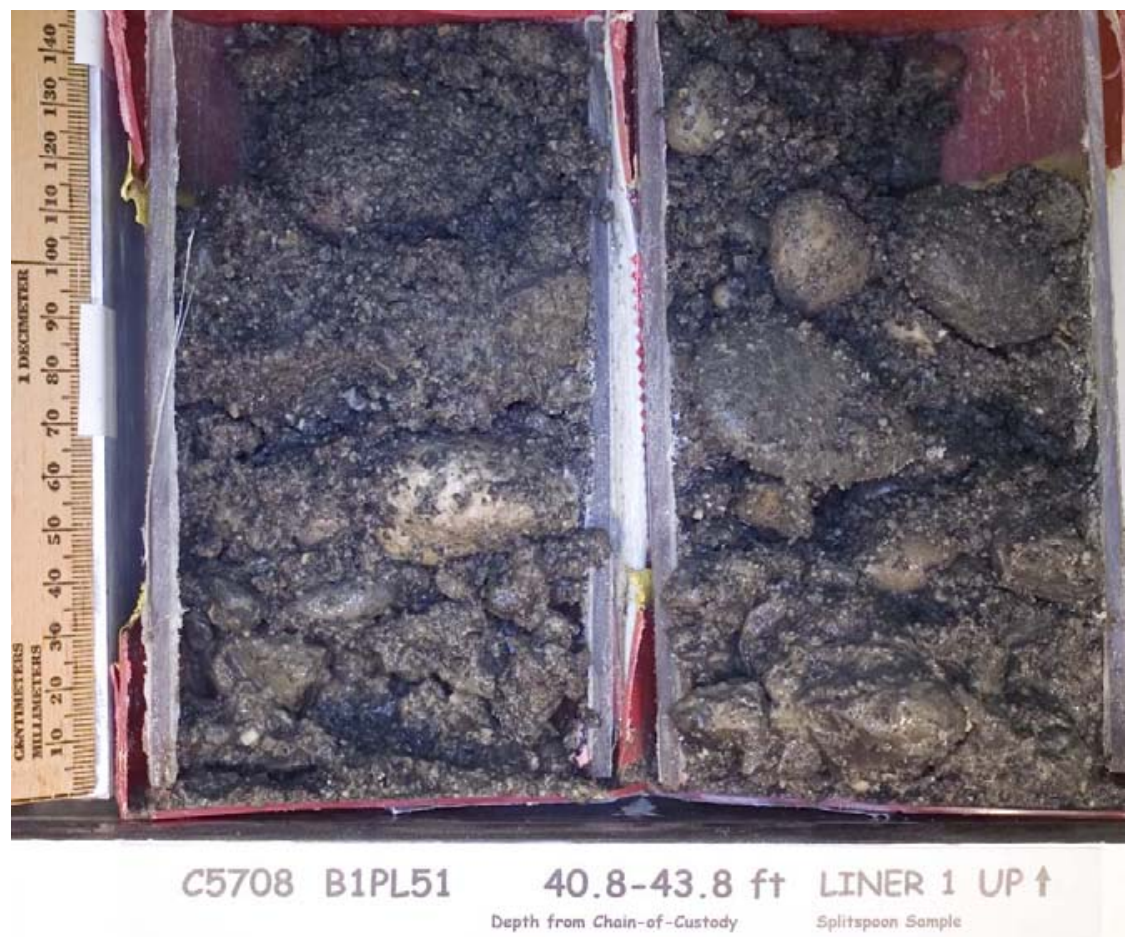

Figure C.31. Photograph of Liner 1 from Sample B1PL51 from Borehole 399-2-5

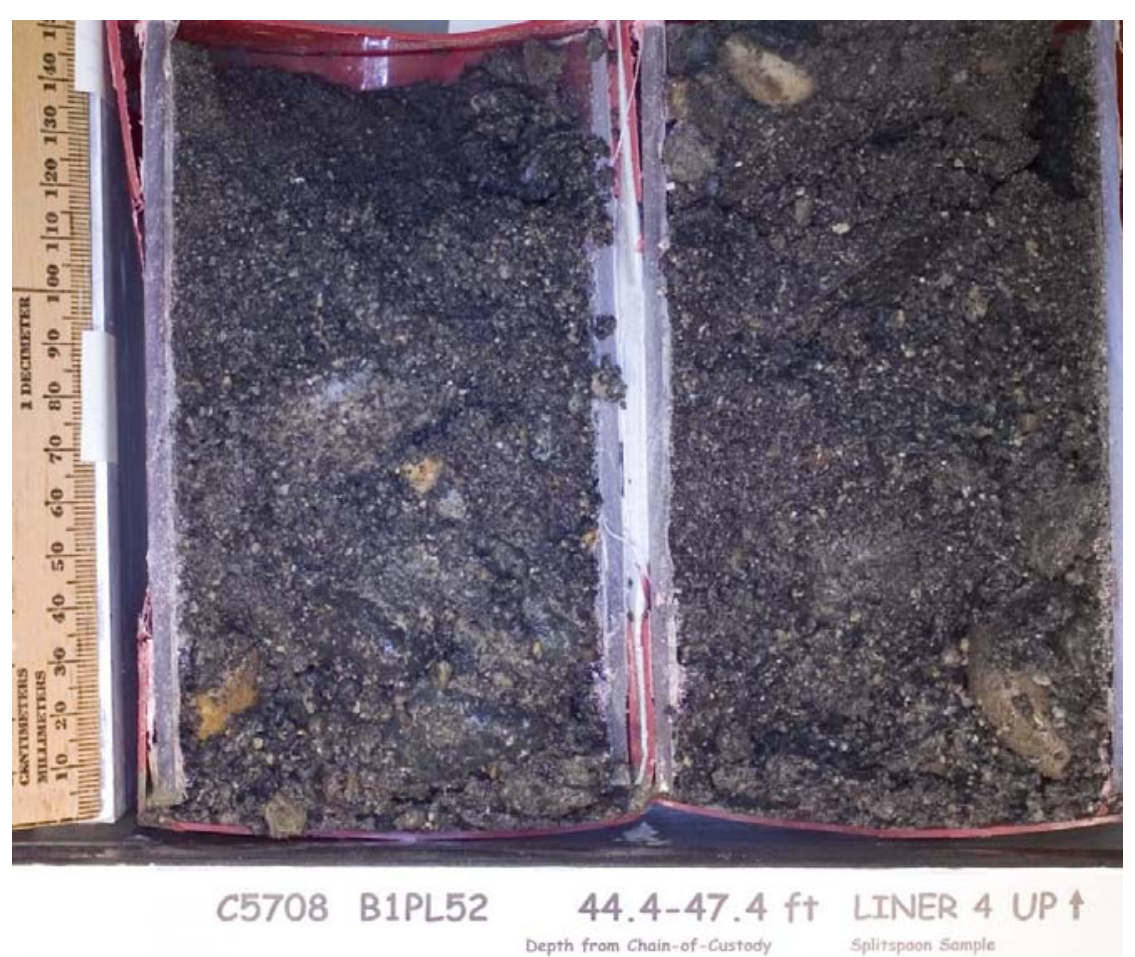

Figure C.32. Photograph of Liner 4 from Sample B1PL52 from Borehole 399-2-5 


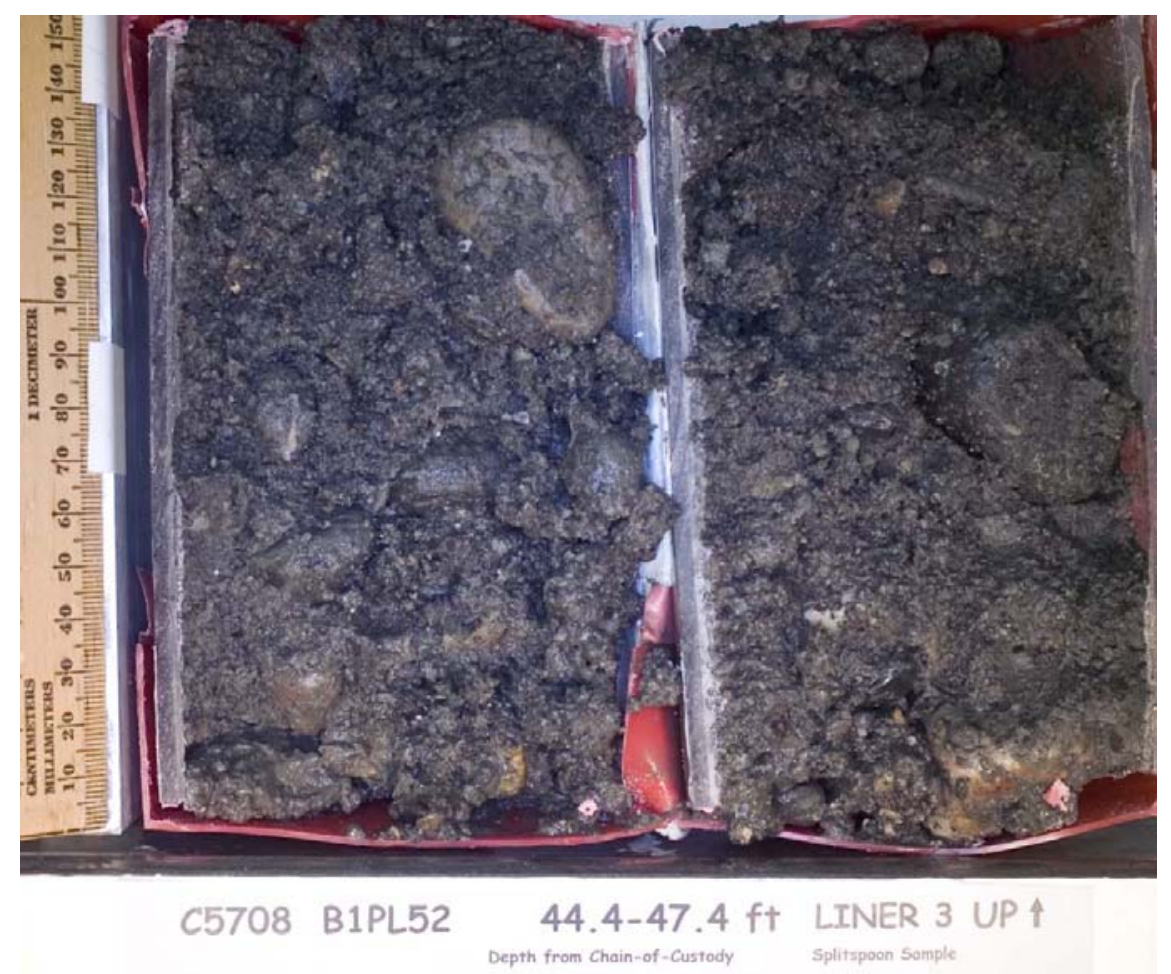

Figure C.33. Photograph of Liner 3 from Sample B1PL52 from Borehole 399-2-5

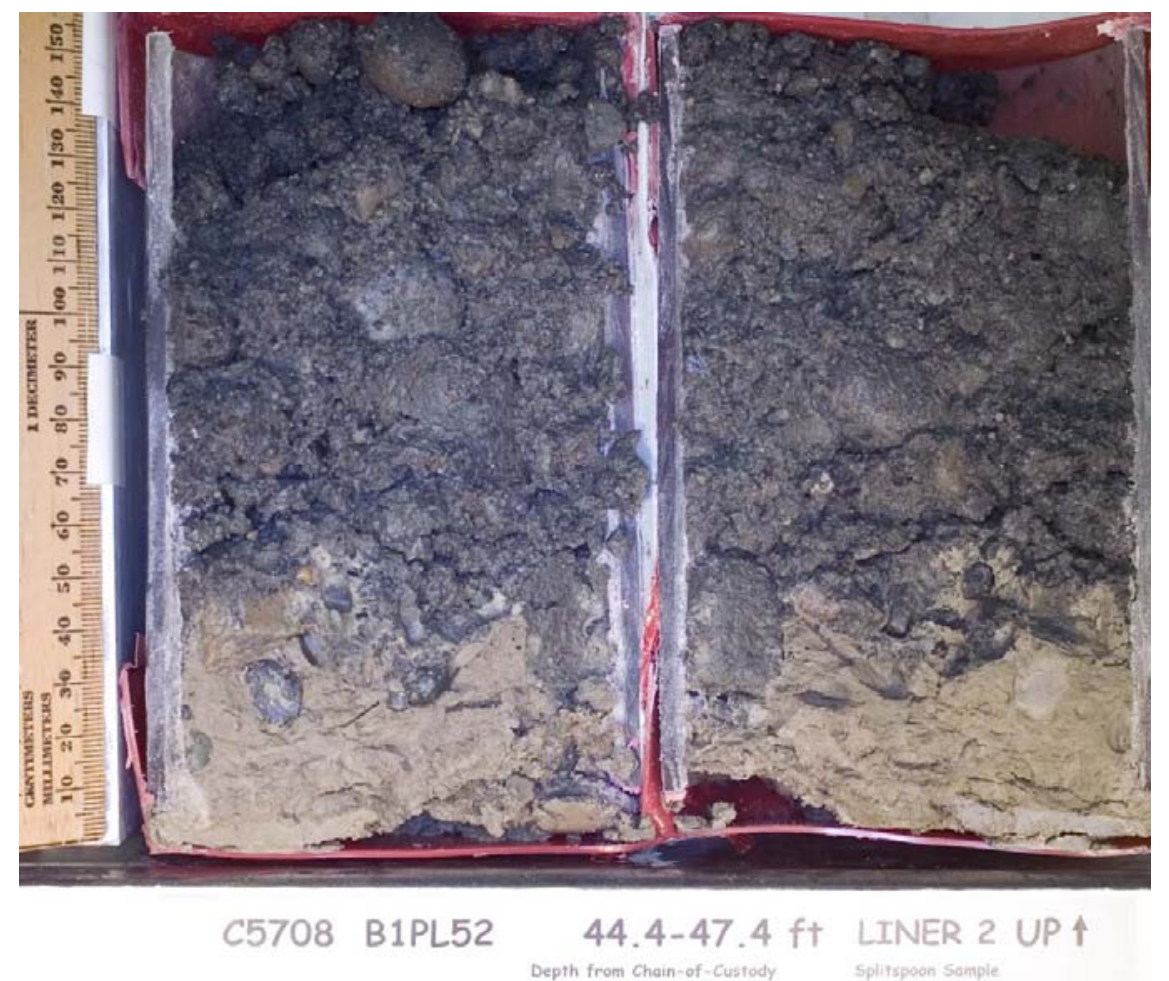

Figure C.34. Photograph of Liner 2 from Sample B1PL52 from Borehole 399-2-5 


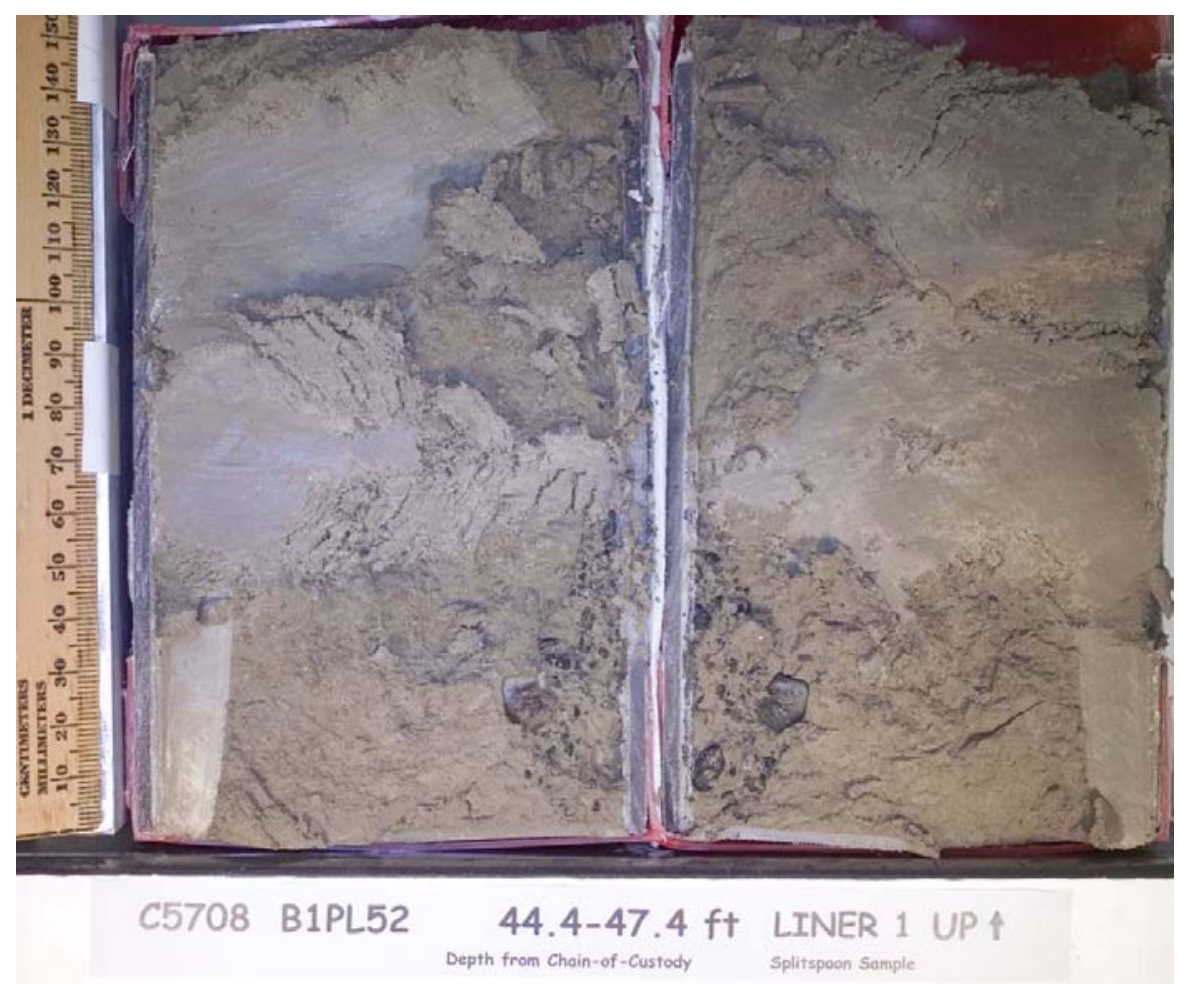

Figure C.35. Photograph of Liner 3 from Sample B1PL53 from Borehole 399-2-5

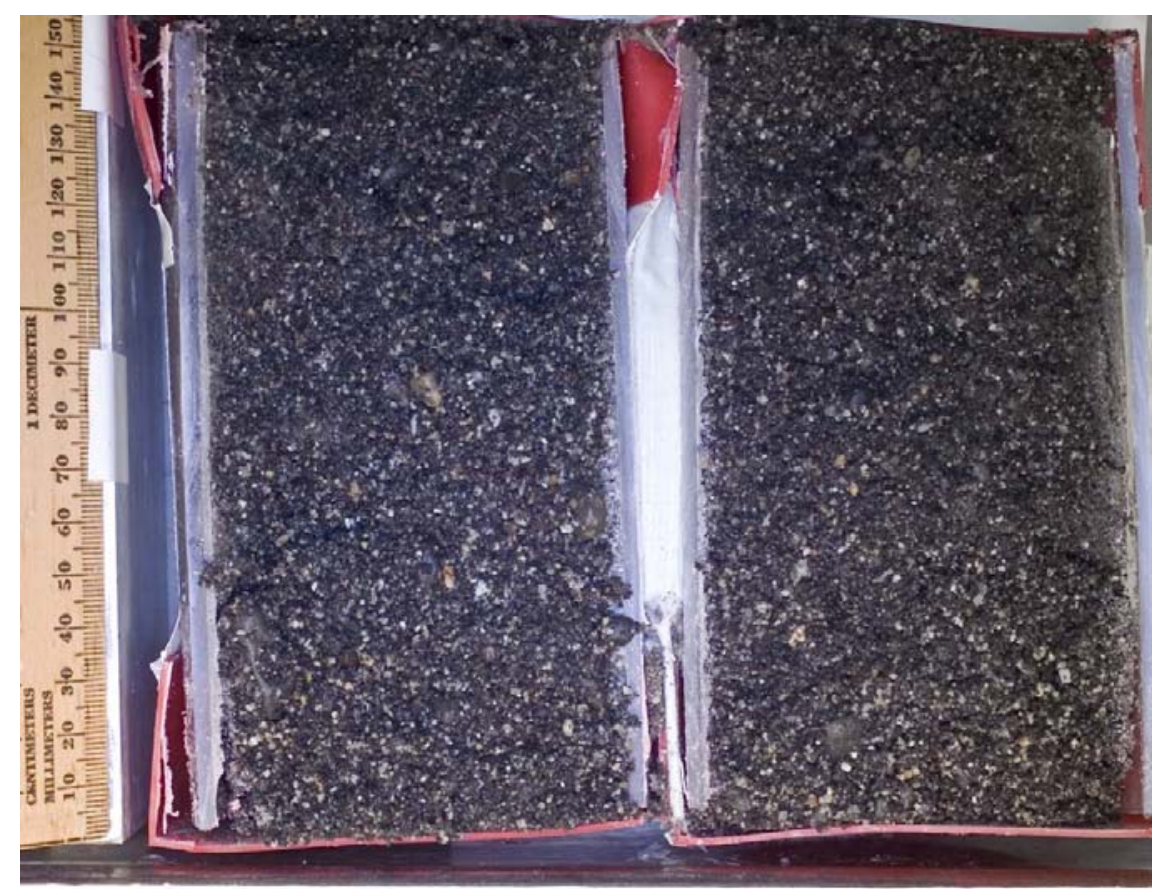

$$
\text { C5708 B1PL53 49.5-52.5 ft LINER } 3 \text { UP } \uparrow
$$

Figure C.36. Photograph of Liner 1 from Sample B1PL52 from Borehole 399-2-5 


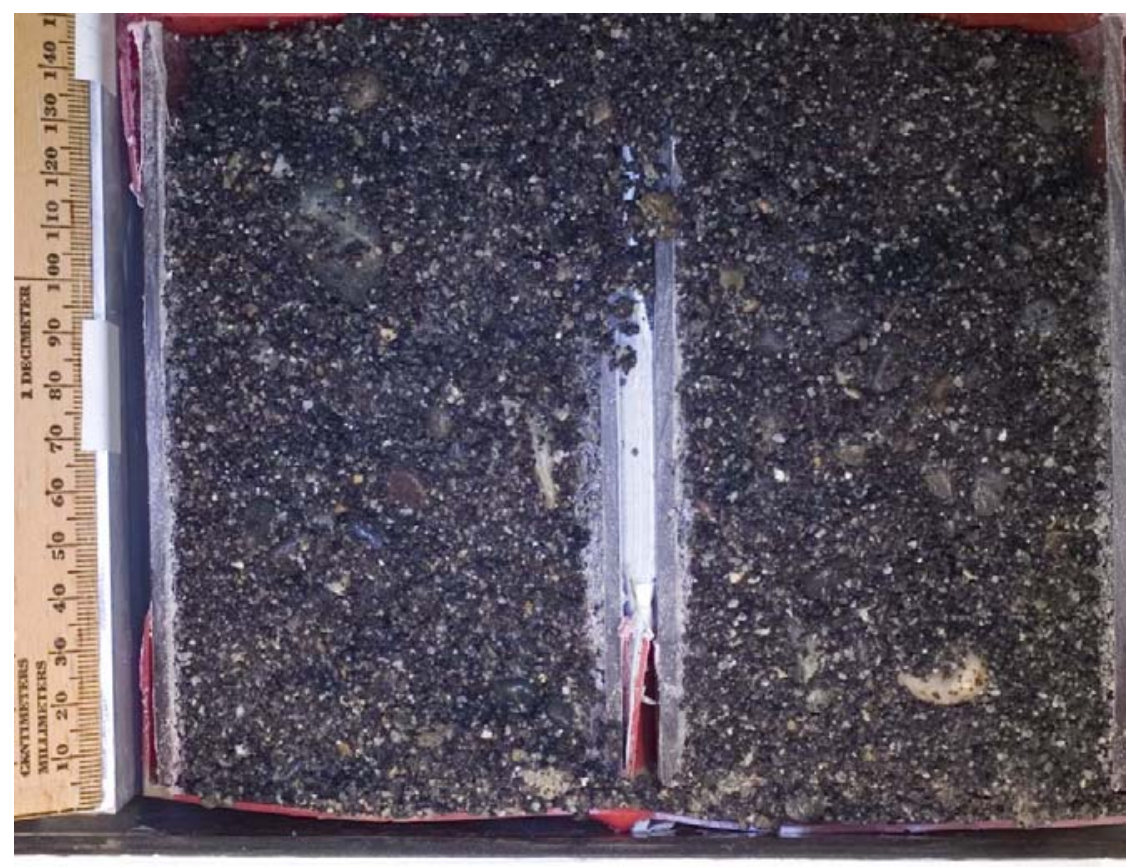

C5708 B1PL53 $49.5-52.5 \mathrm{ft}$ LINER 2 UP $\uparrow$

Figure C.37. Photograph of Liner 3 from Sample B1PL53 from Borehole 399-2-5

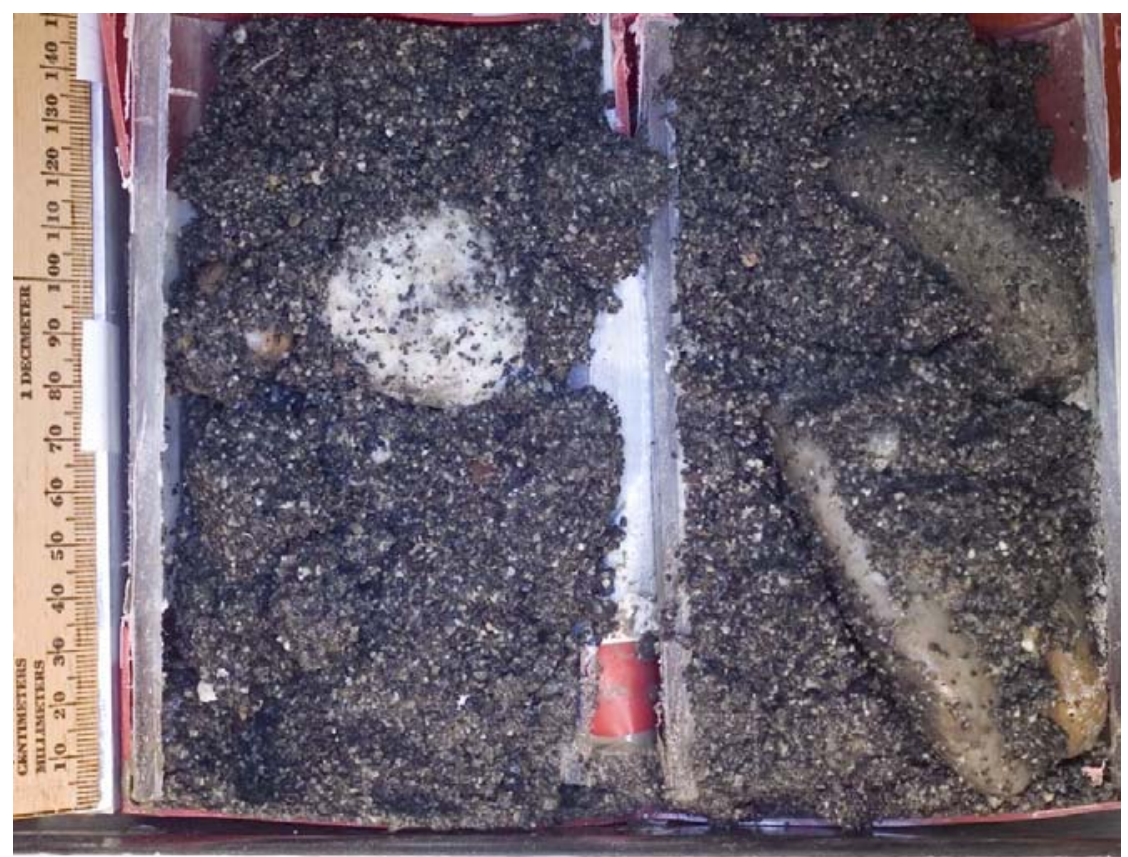

$$
\text { C5708 B1PL53 49.5-52.5 ft LINER } 1 \text { UP } \uparrow
$$

Figure C.38. Photograph of Liner 1 from Sample B1 PL53 from Borehole 399-2-5 

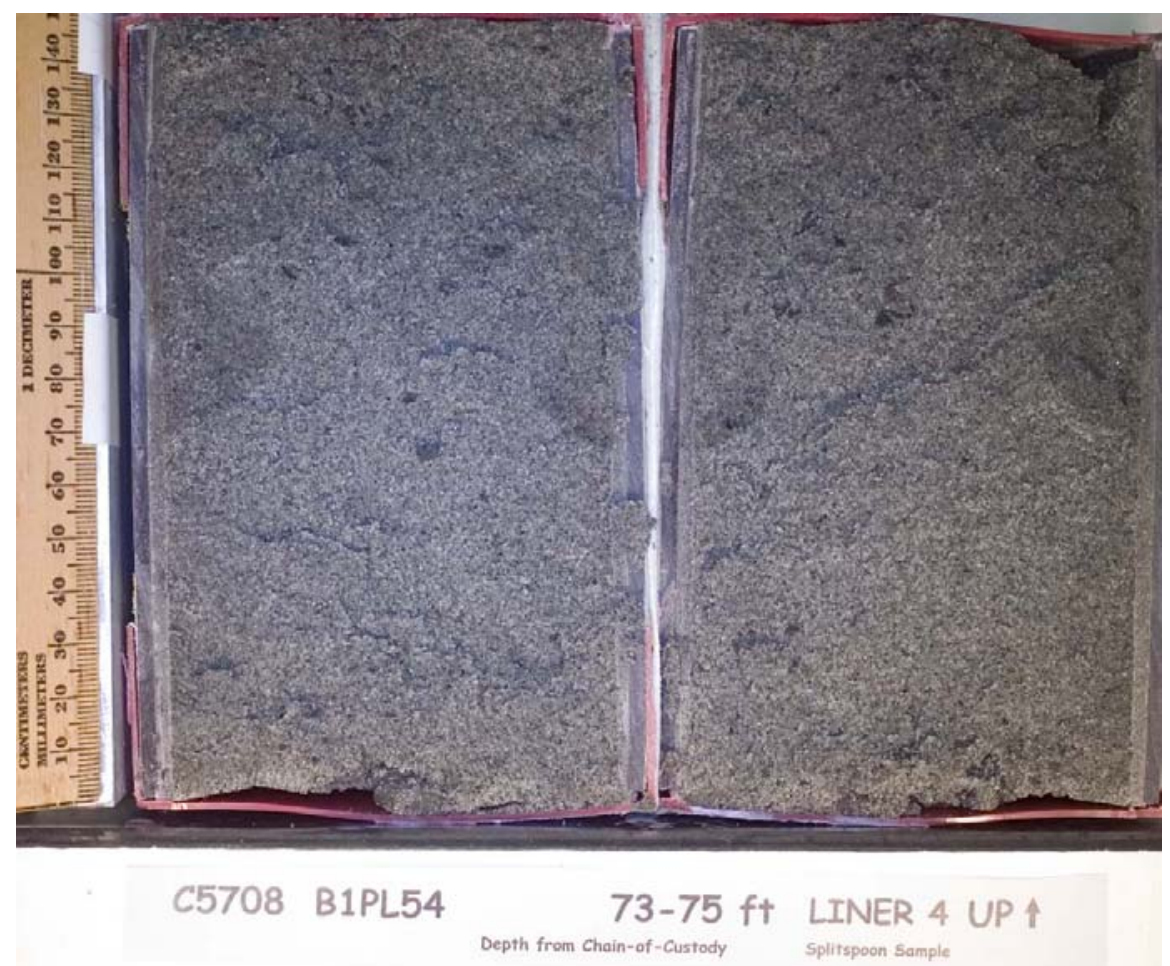

Figure C.39. Photograph of Liner 4 from Sample B1PL54 from Borehole 399-2-5

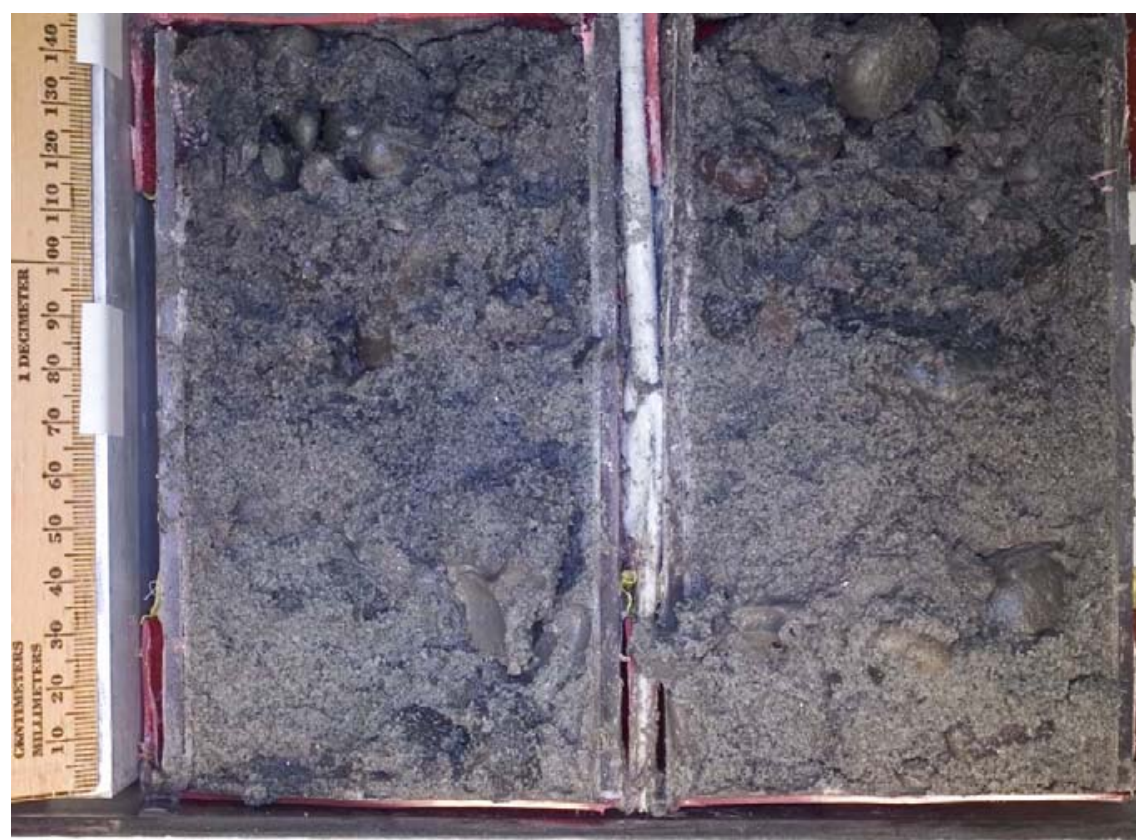

C5708 B1PL54

$73-75 \mathrm{ft}$ LINER 3 UP $\uparrow$

Figure C.40. Photograph of Liner 3 from Sample B1 PL54 from Borehole 399-2-5 


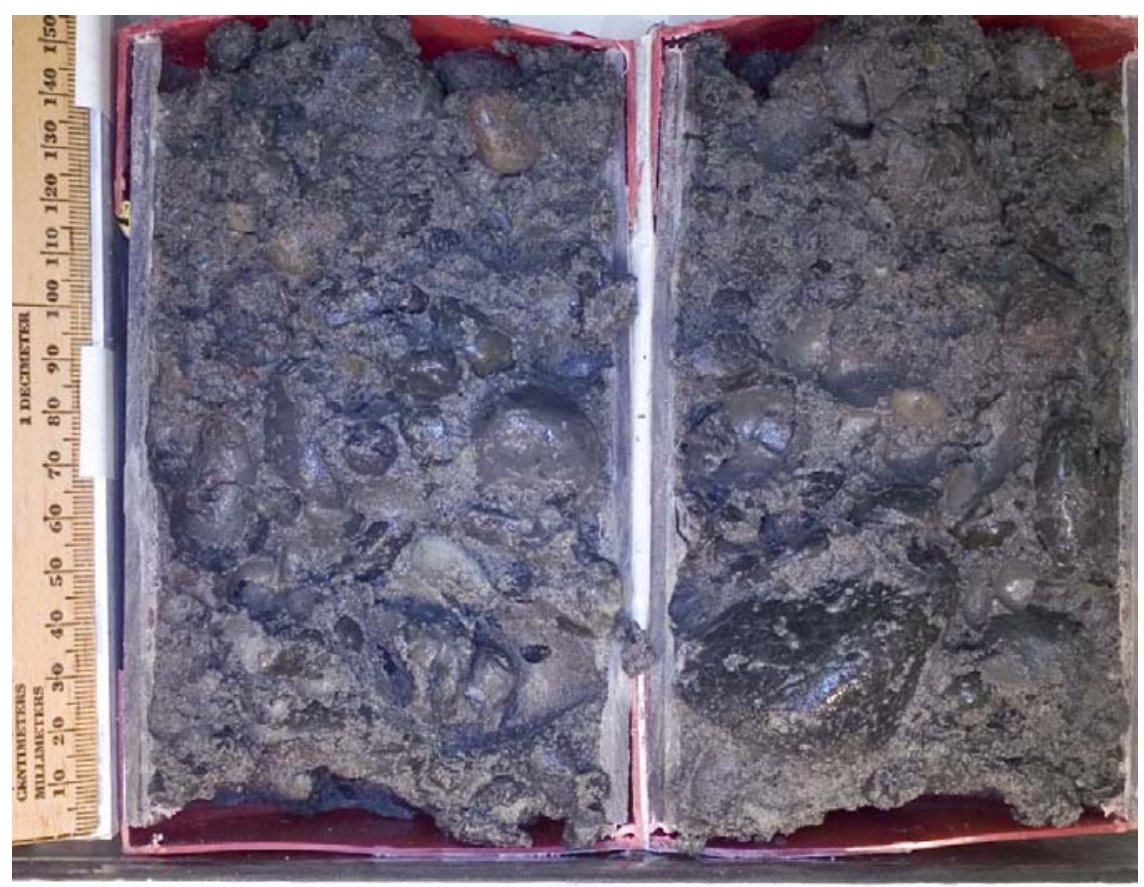

C5708 B1PL54

73-75 ft LINER 2 UP $\uparrow$

Depth from Chain-of-custody spilitspoon Sample

Figure C.41. Photograph of Liner 2 from Sample B1PL54 from Borehole 399-2-5

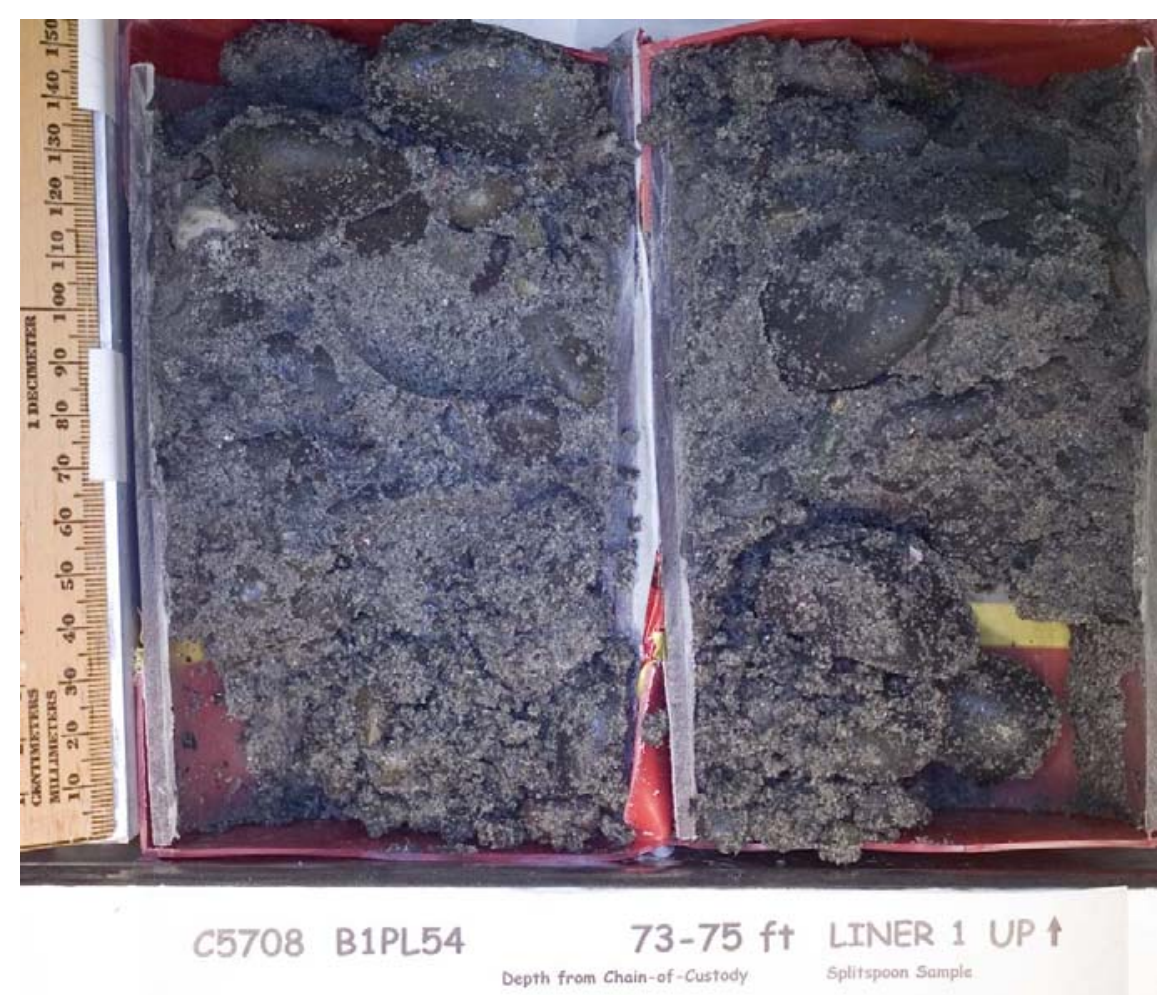

Figure C.42. Photograph of Liner 1 from Sample B1PL54 from Borehole 399-2-5 



\section{Appendix D}

Photographs of Samples Collected from Borehole C5707 



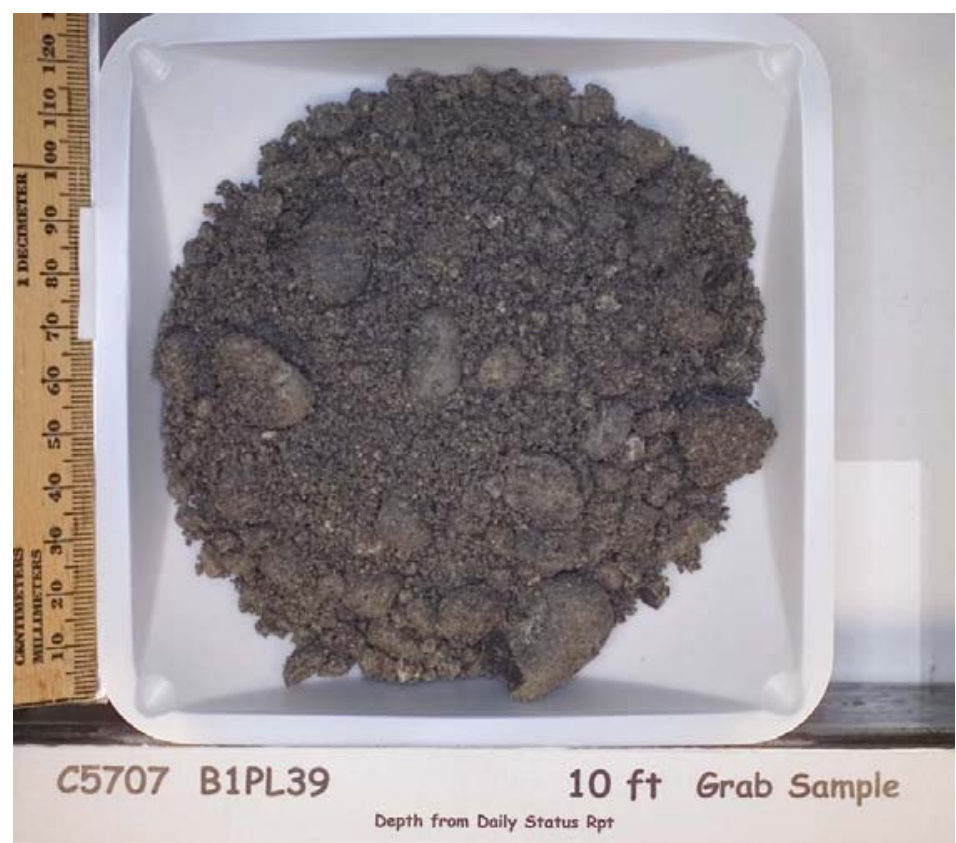

Figure D.1. Photograph of Grab Sample B1PL39 from Borehole 399-4-14

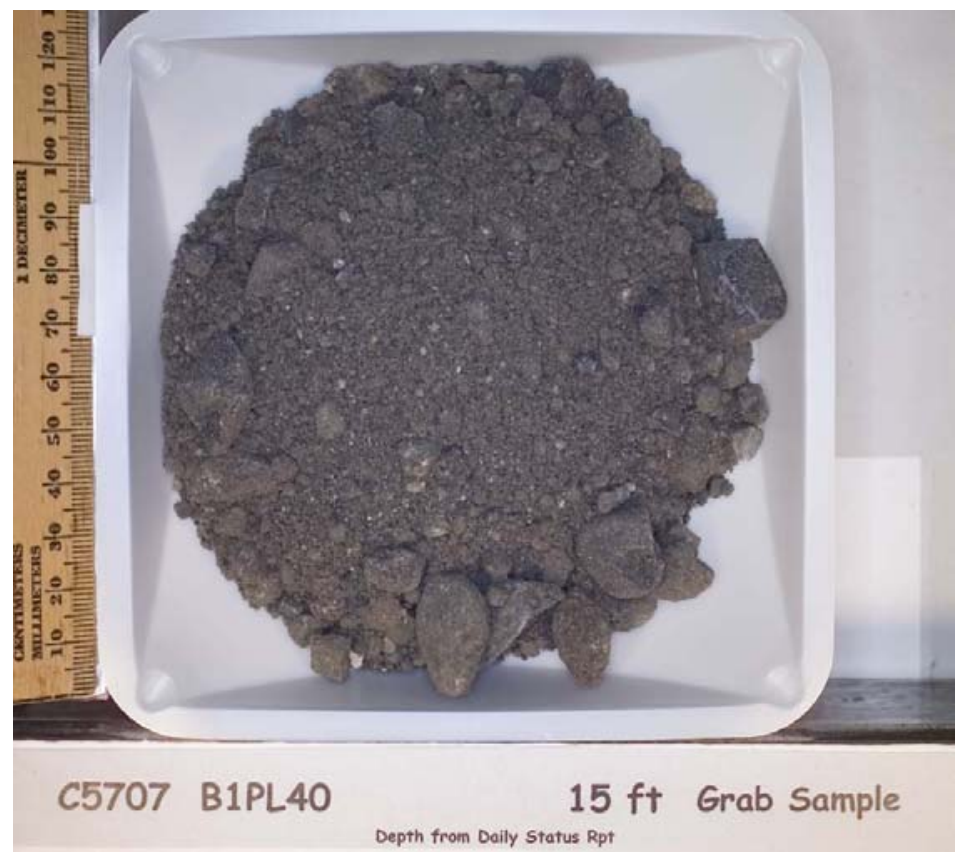

Figure D.2. Photograph of Grab Sample B1PL40 from Borehole 399-4-14 


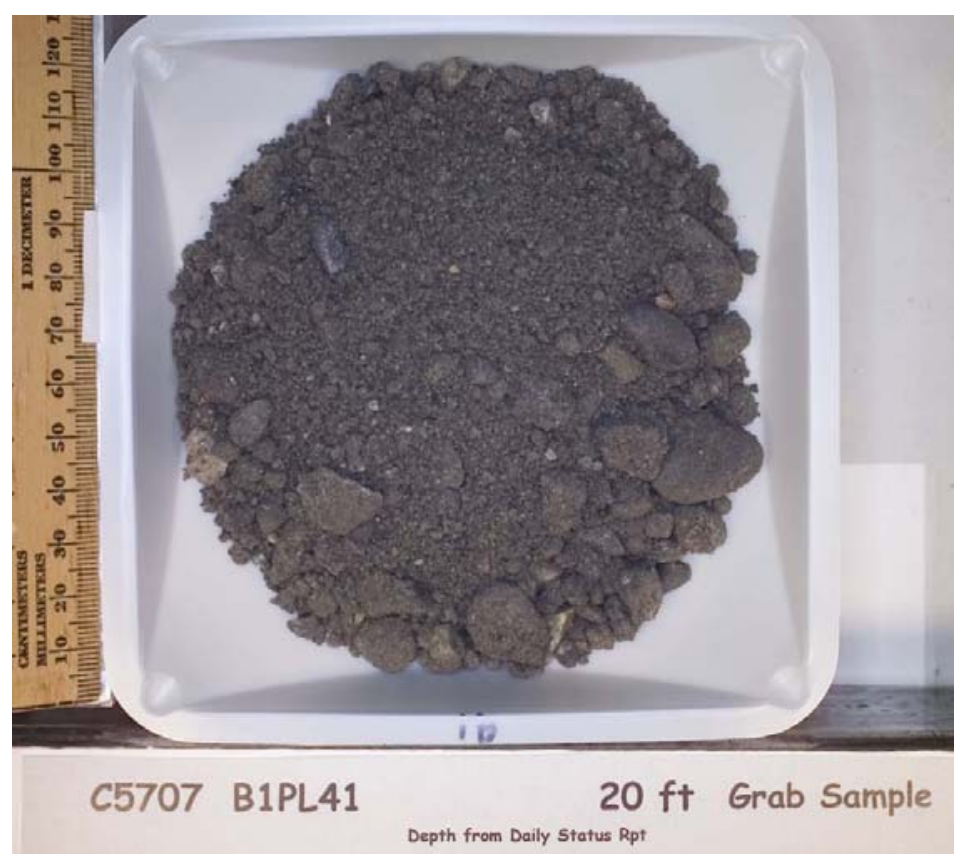

Figure D.3. Photograph of Grab Sample B1PL41 from Borehole 399-4-14

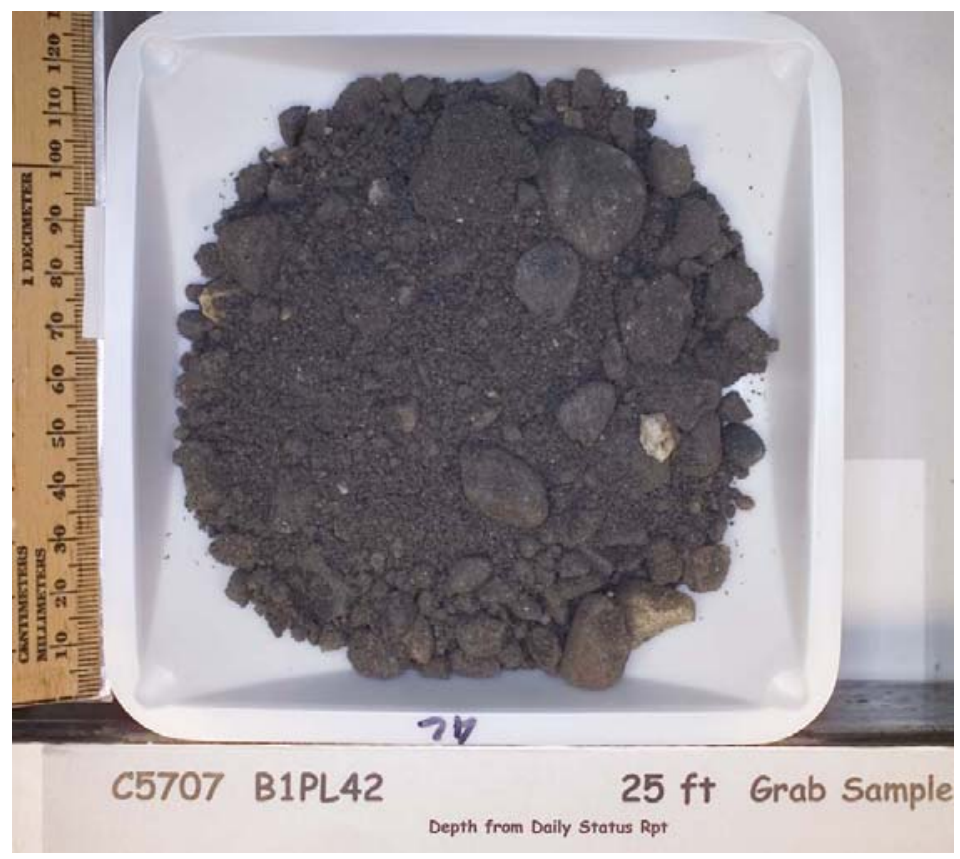

Figure D.4. Photograph of Grab Sample B1PL42 from Borehole 399-4-14 


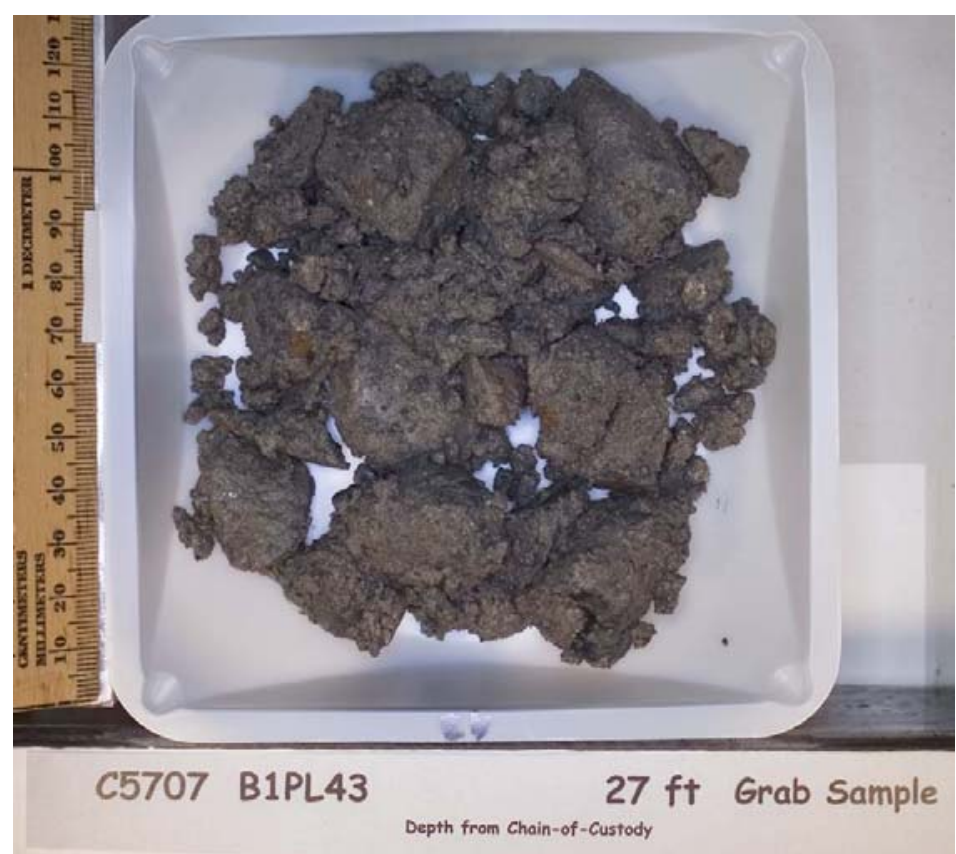

Figure D.5. Photograph of Grab Sample B1PL43 from Borehole 399-4-14

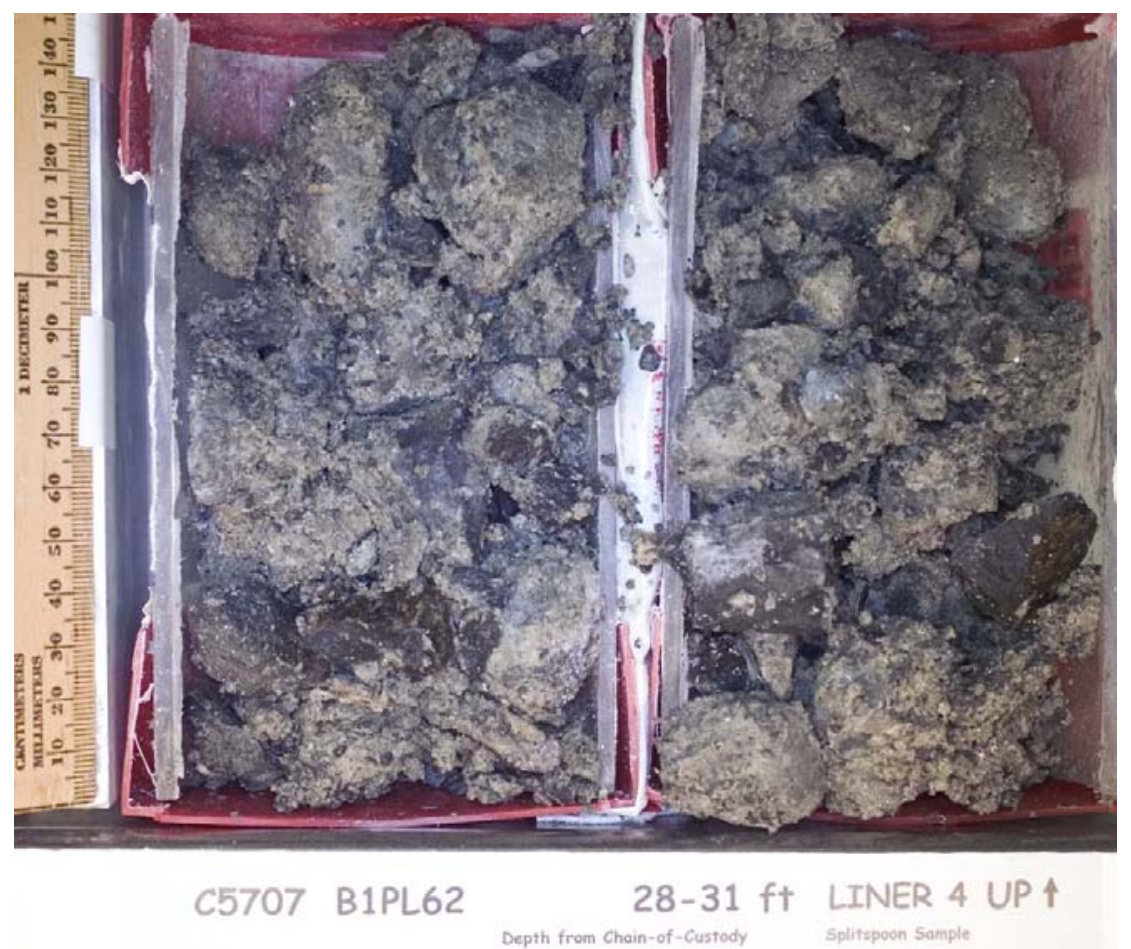

Figure D.6. Photograph of Liner 4 from Sample B1PL62 from Borehole 399-4-14 


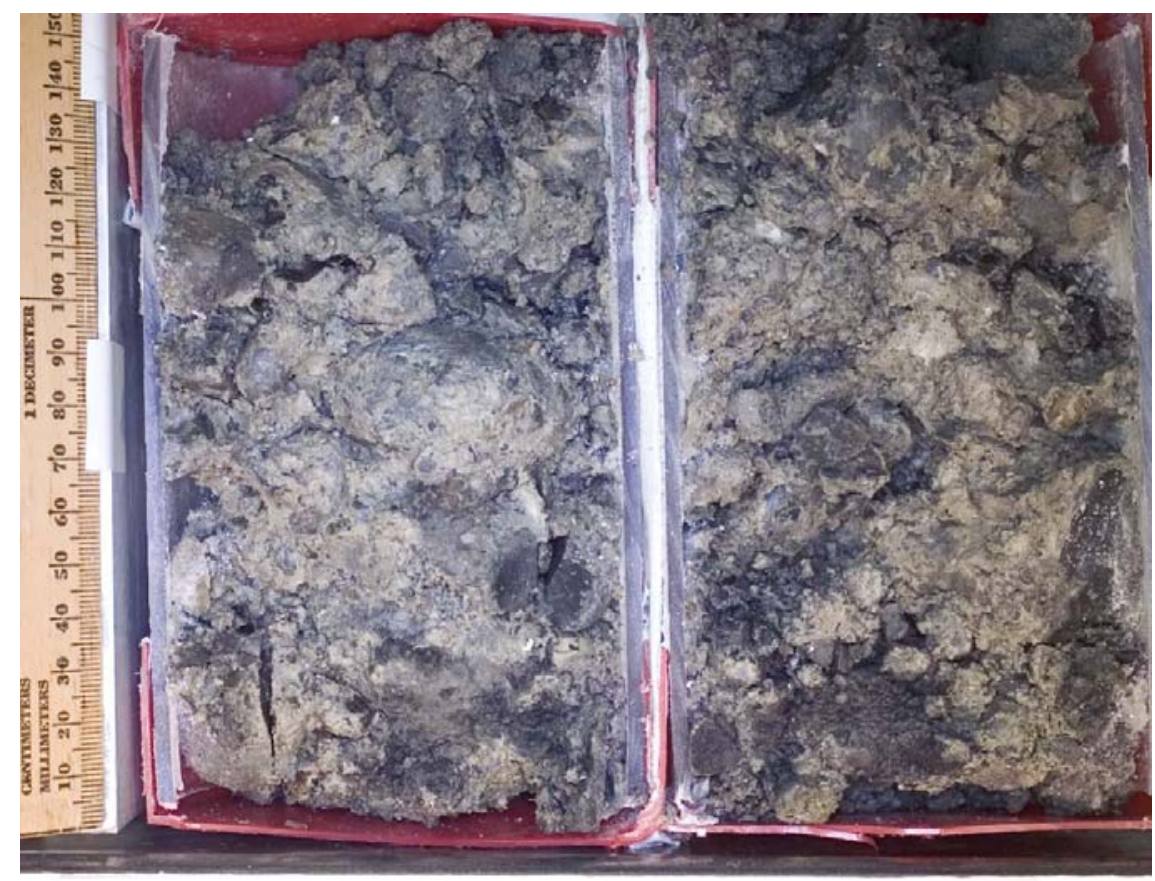

$$
\text { C5707 B1PL62 } 28-31 \mathrm{ft} \text { LINER } 3 \text { UP } \uparrow
$$

Figure D.7. Photograph of Liner 3 from Sample B1PL62 from Borehole 399-4-14

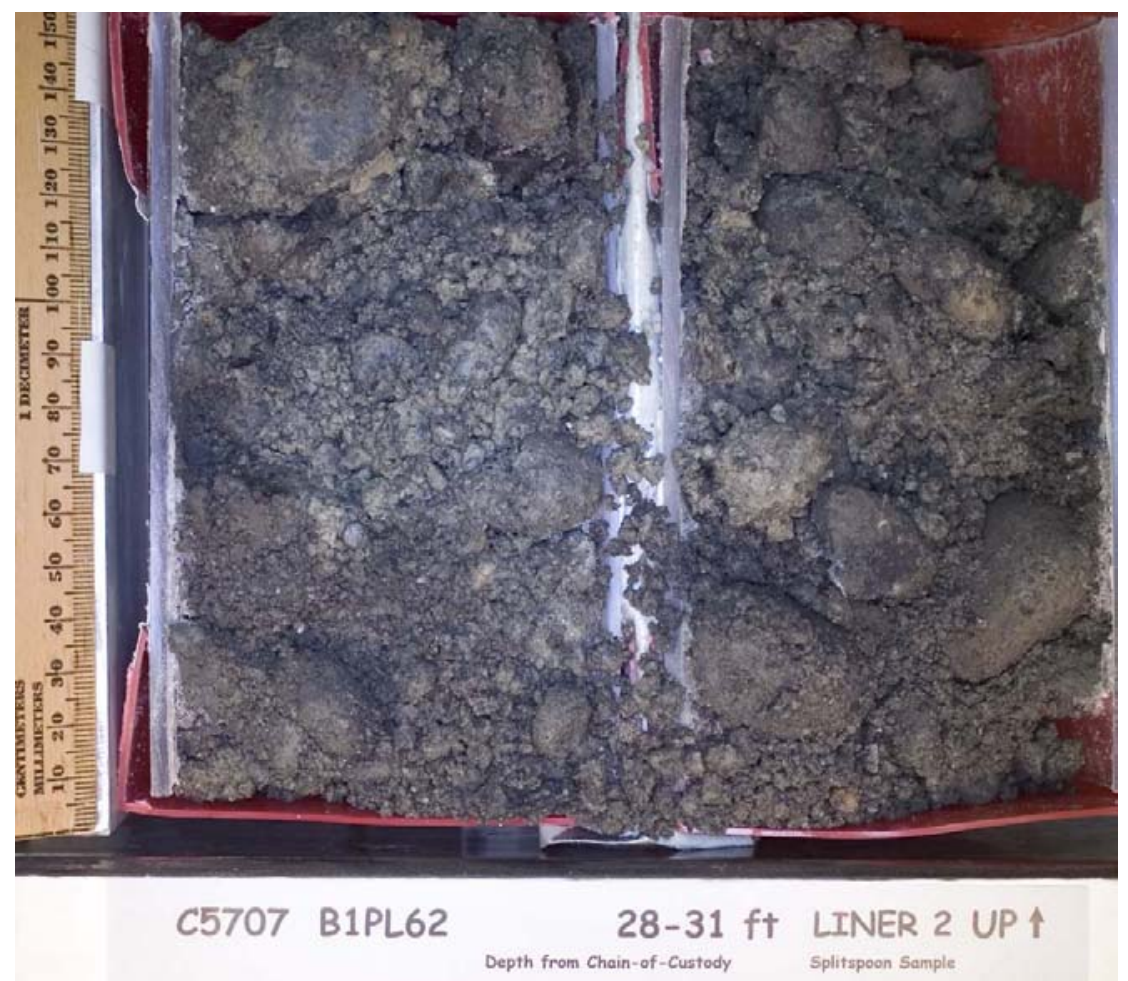

Figure D.8. Photograph of Liner 2 from Sample B1PL62 from Borehole 399-4-14 


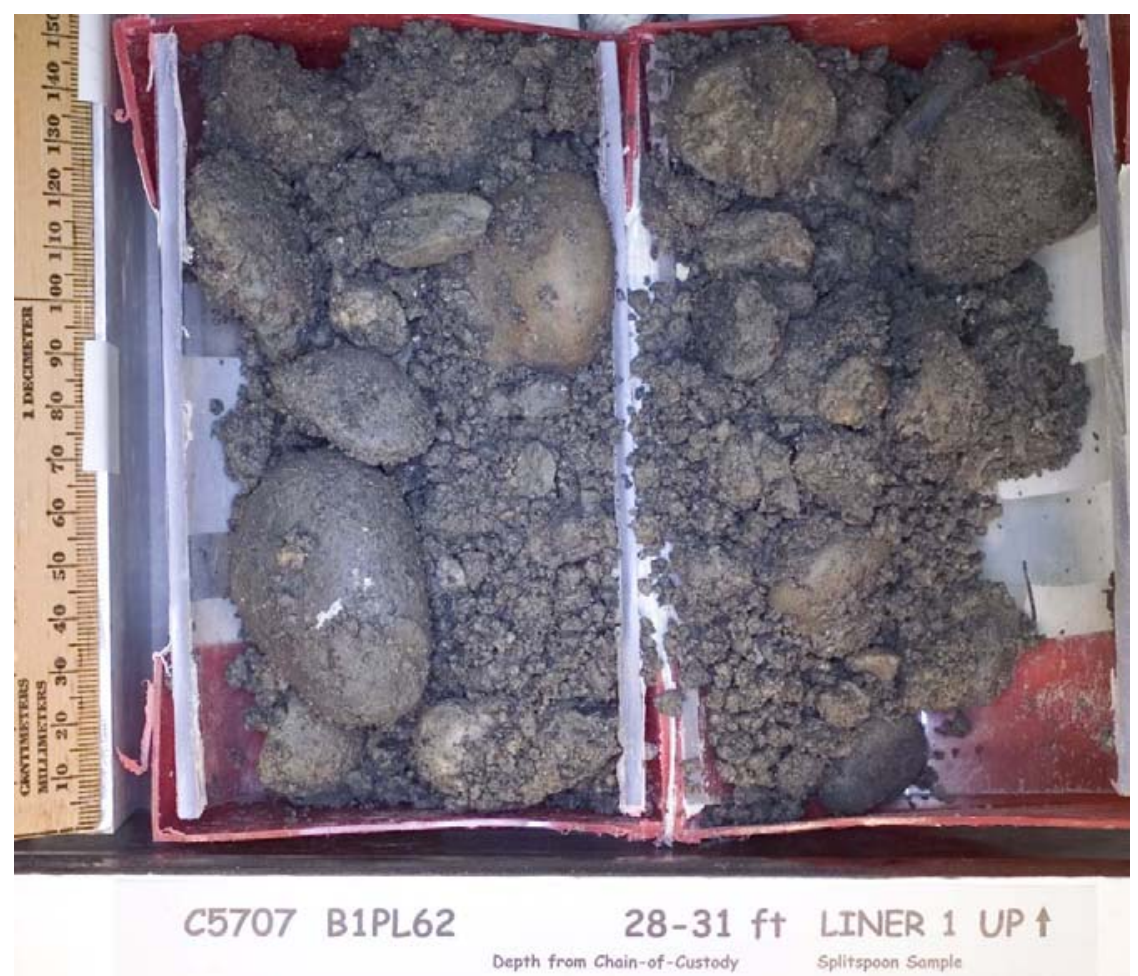

Figure D.9. Photograph of Liner 1 from Sample B1PL62 from Borehole 399-4-14

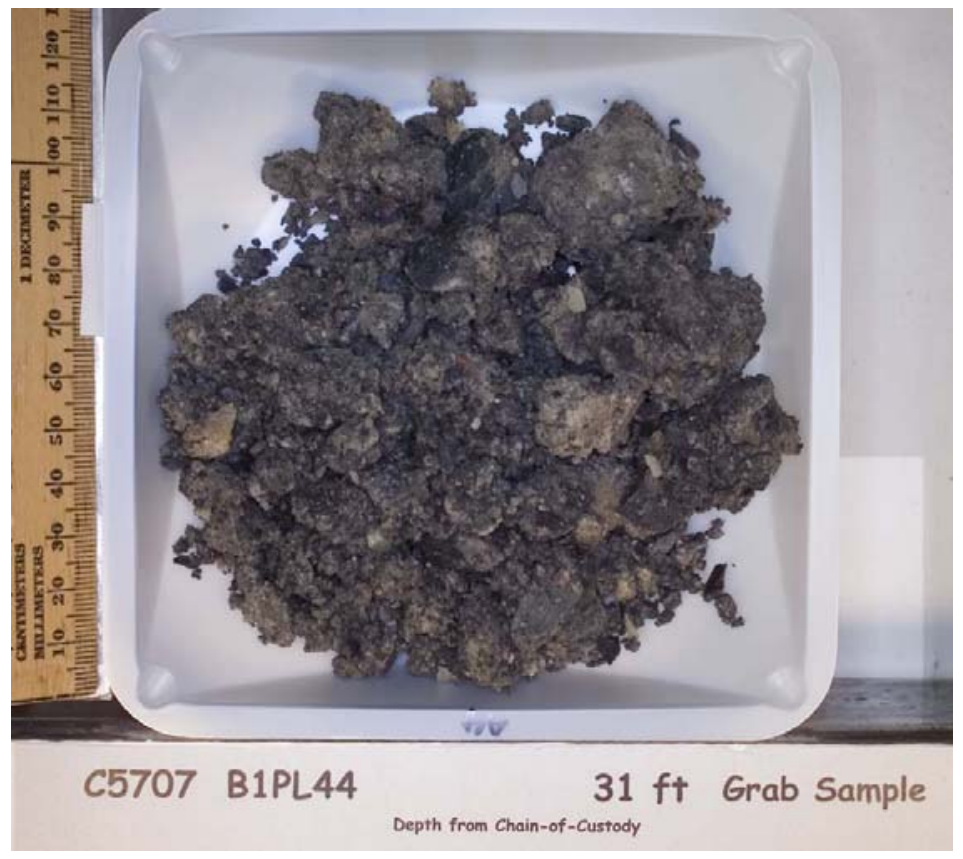

Figure D.10. Photograph of Grab Sample B1PL44 from Borehole 399-4-14 


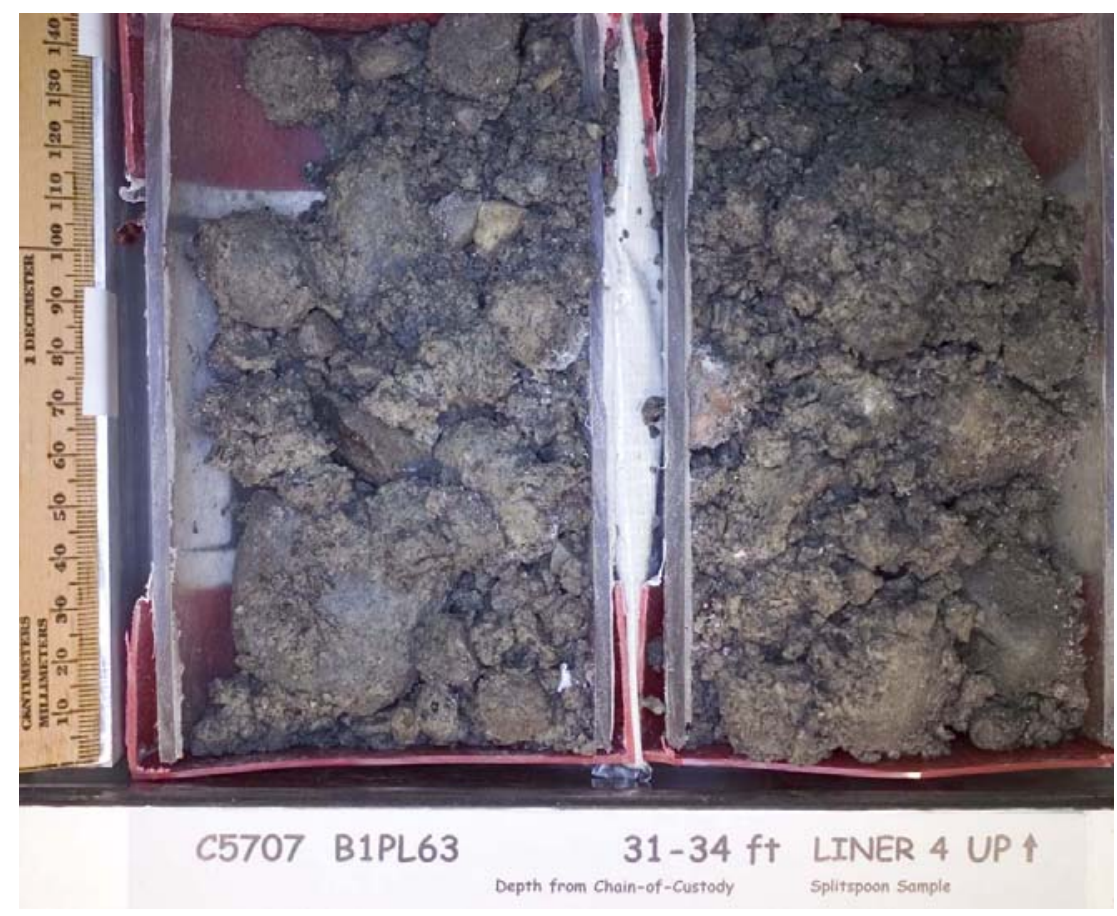

Figure D.11. Photograph of Liner 4 from Sample B1PL63 from Borehole 399-4-14

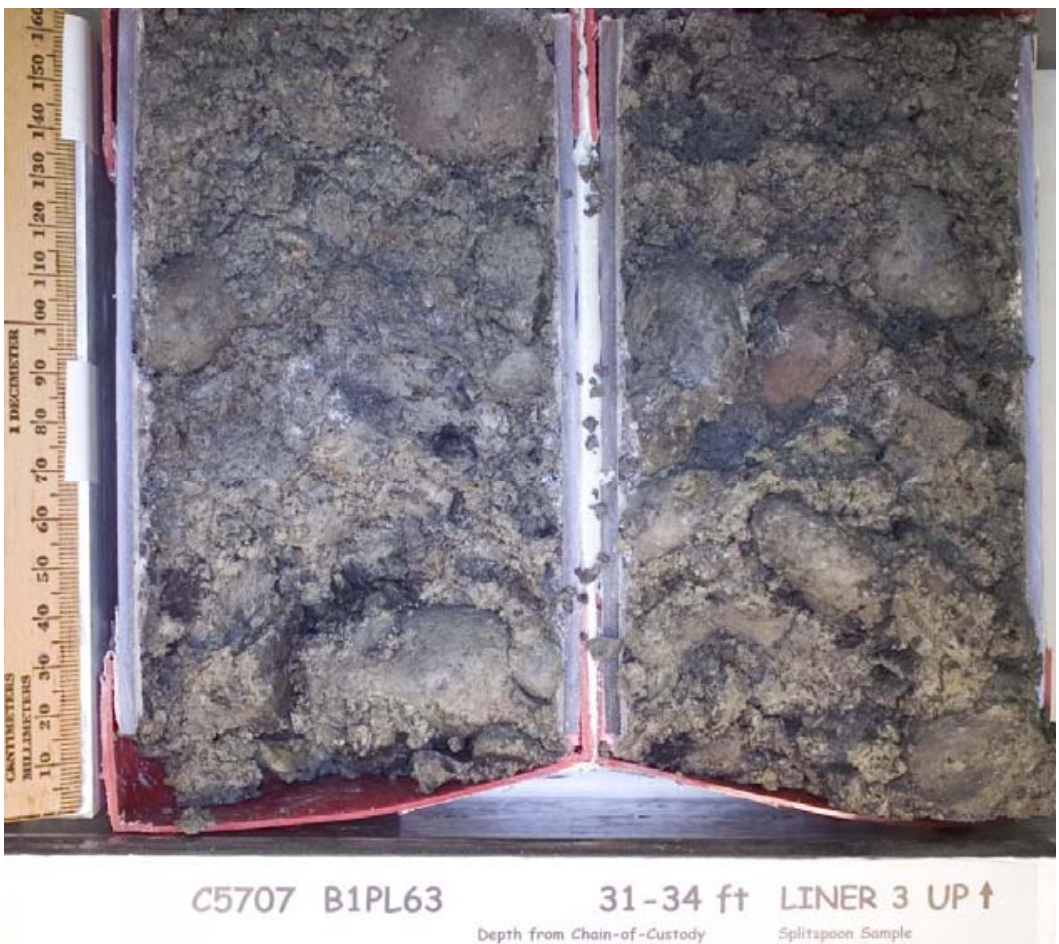

Figure D.12. Photograph of Liner 3 from Sample B1PL63 from Borehole 399-4-14 


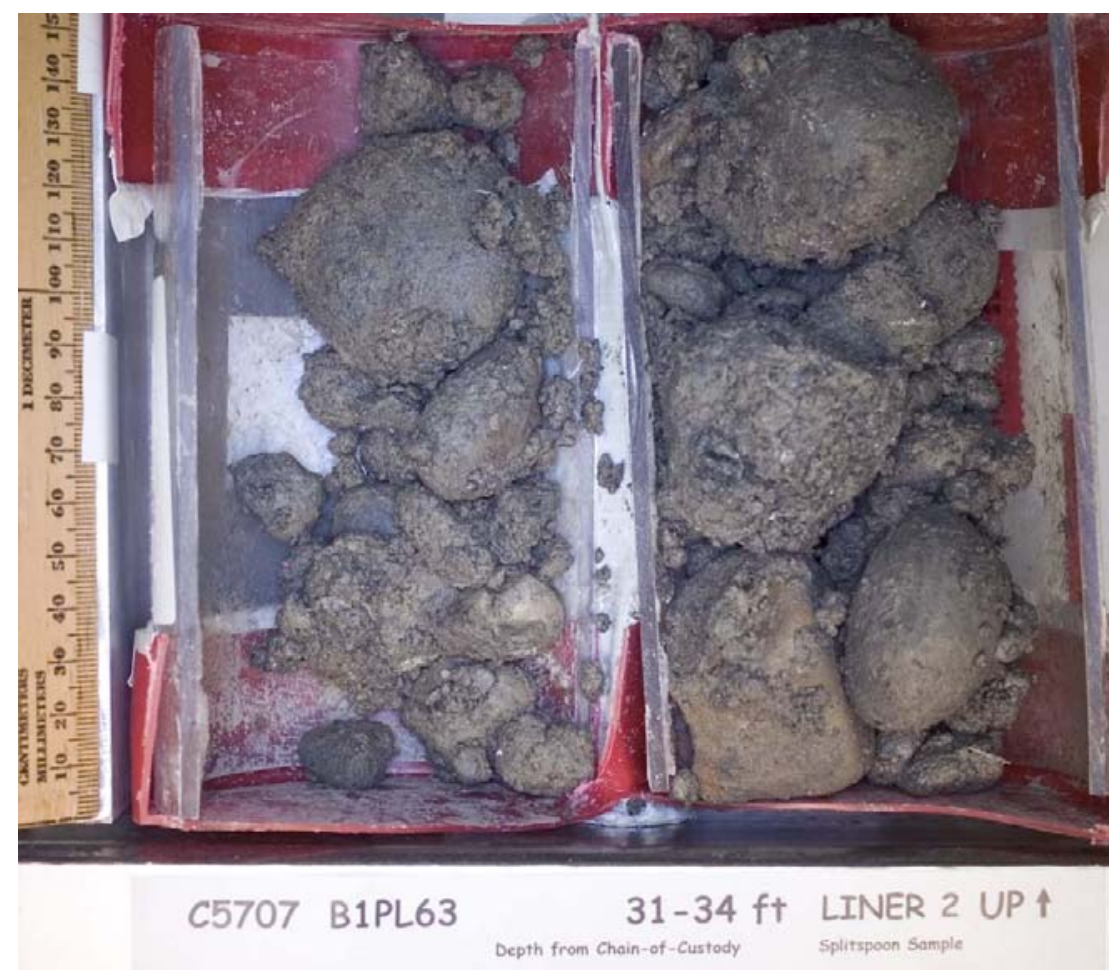

Figure D.13. Photograph of Liner 2 from Sample B1PL63 from Borehole 399-4-14

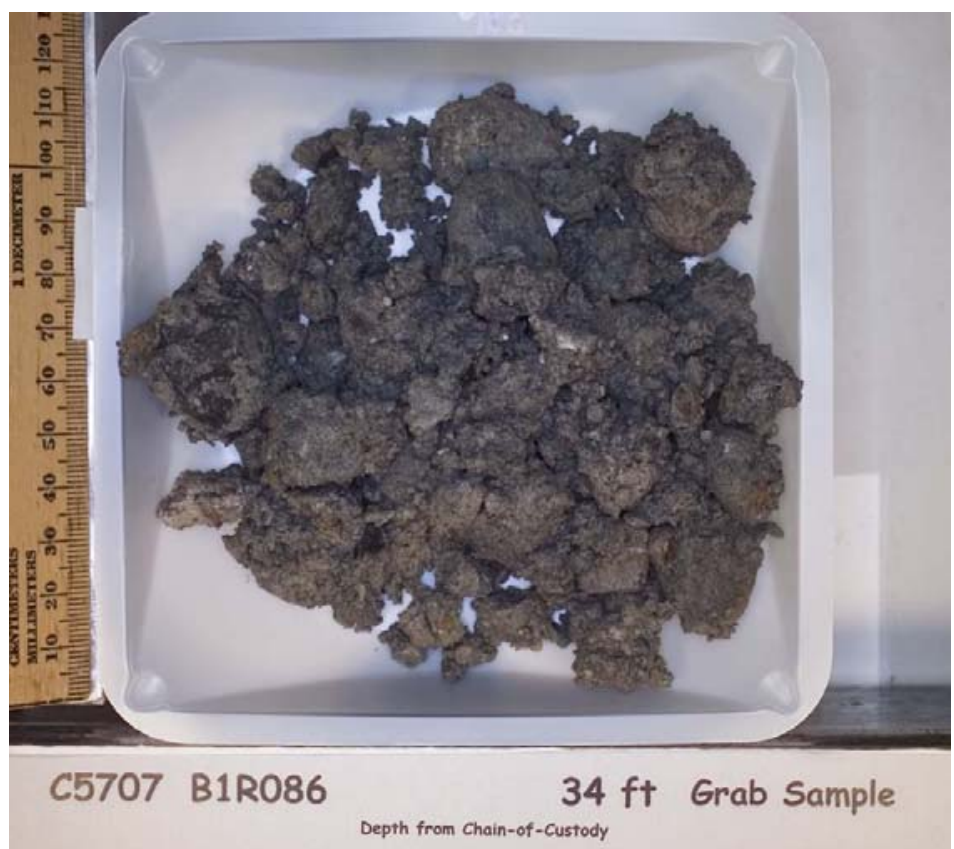

Figure D.14. Photograph of Grab Sample B1R086 from Borehole 399-4-14 


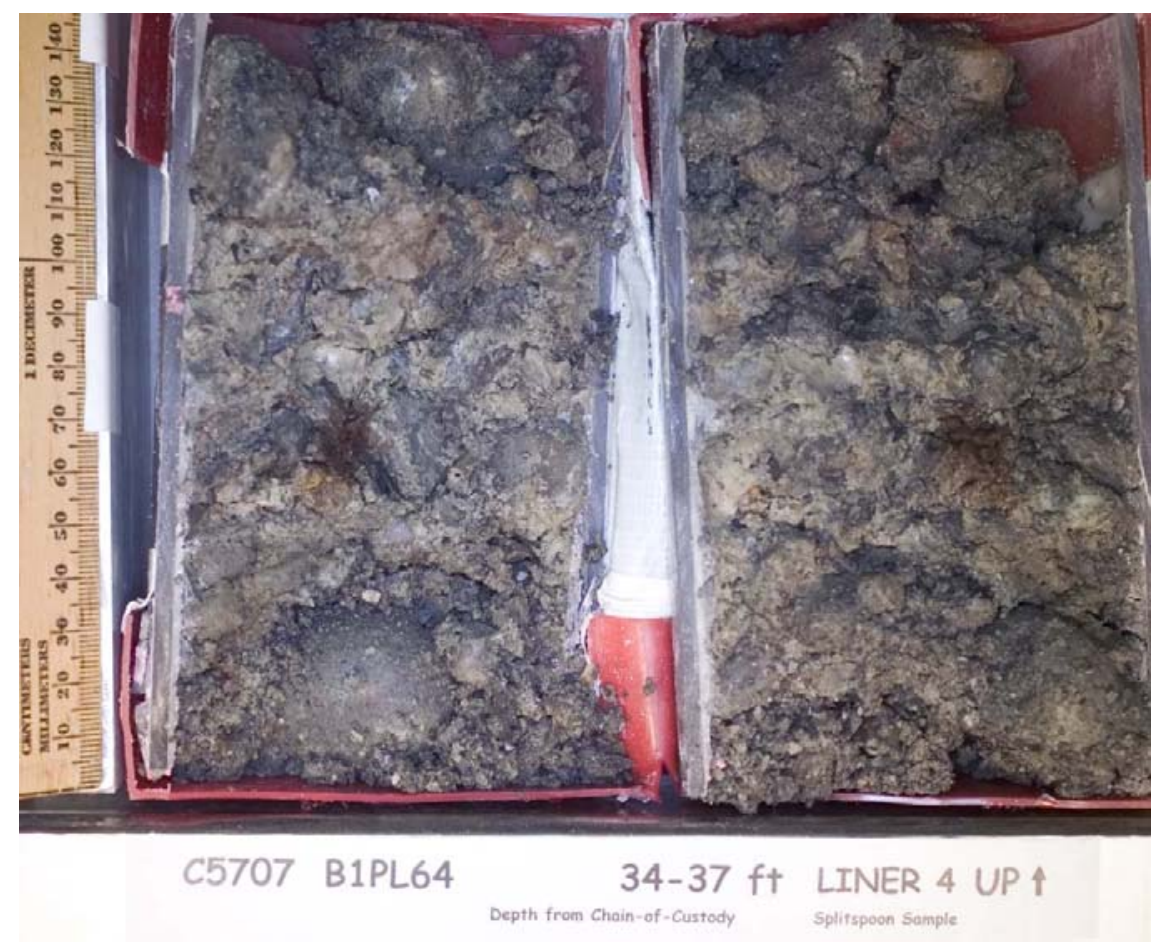

Figure D.15. Photograph of Liner 4 from Sample B1PL64 from Borehole 399-4-14

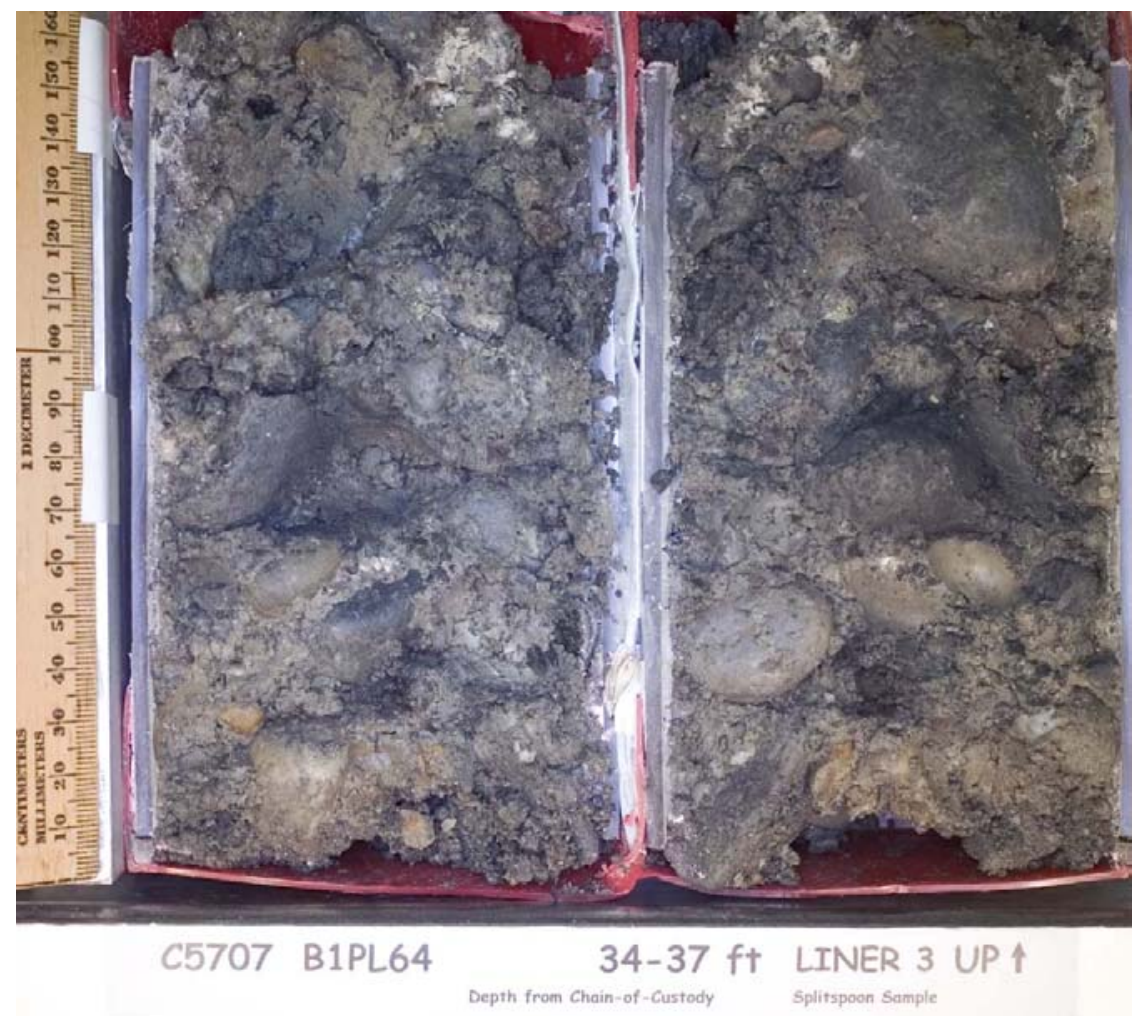

Figure D.16. Photograph of Liner 3 from Sample B1PL64 from Borehole 399-4-14 


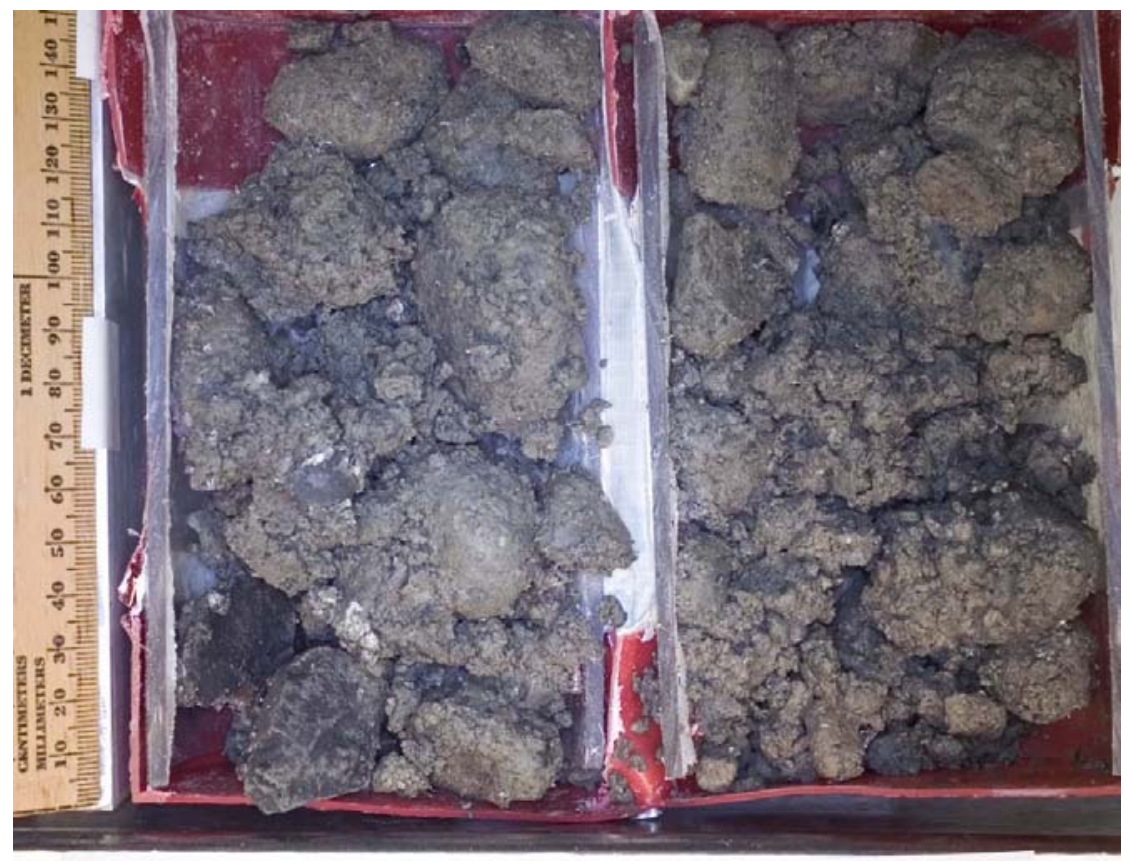

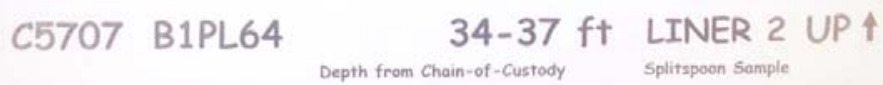

Figure D.17. Photograph of Liner 2 from Sample B1PL64 from Borehole 399-4-14

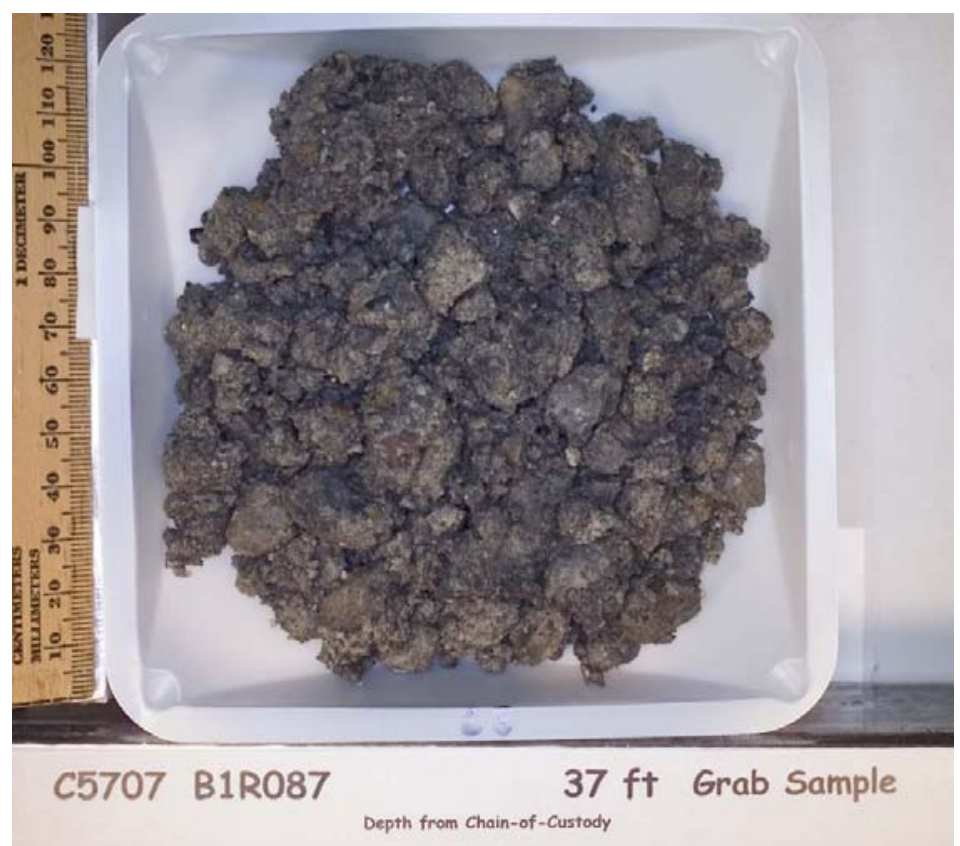

Figure D.18. Photograph of Grab Sample B1R087 from Borehole 399-4-14 


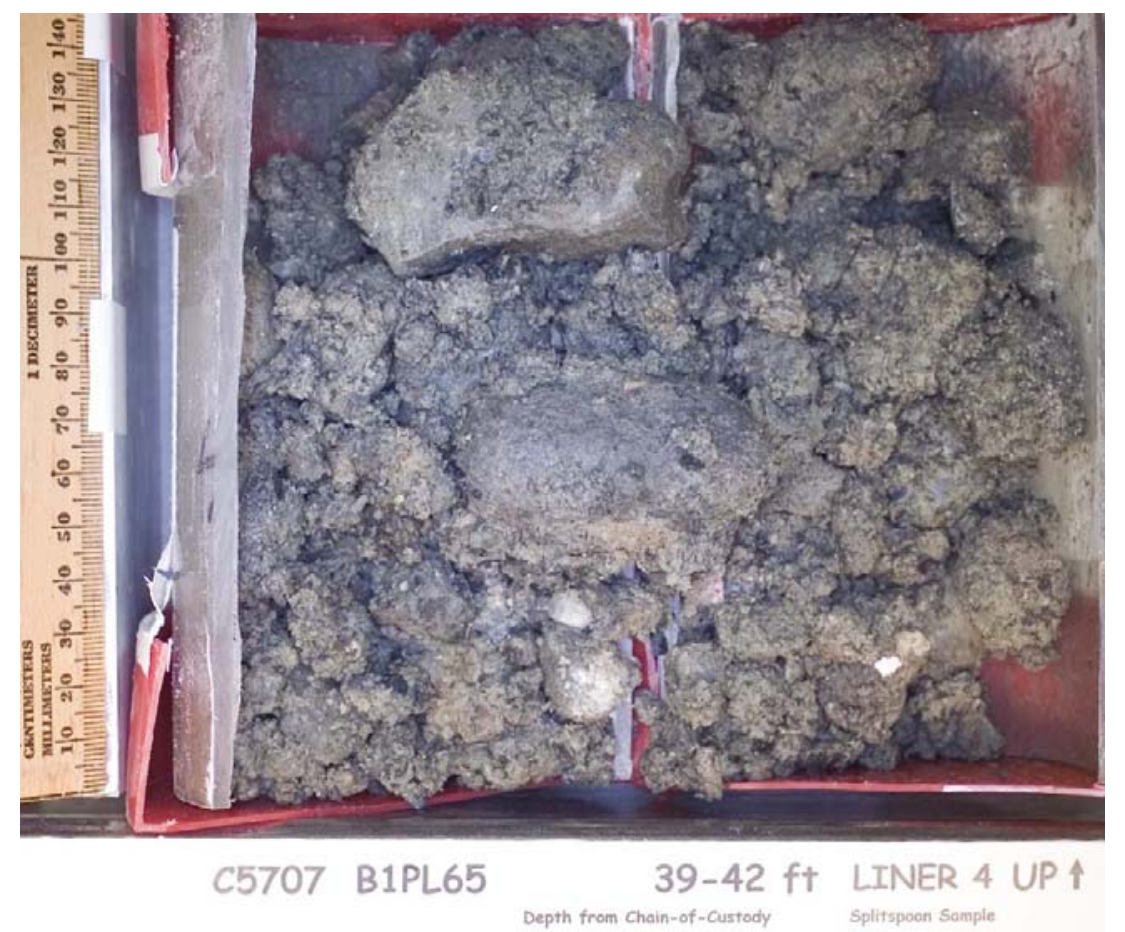

Figure D.19. Photograph of Liner 4 from Sample B1PL65 from Borehole 399-4-14

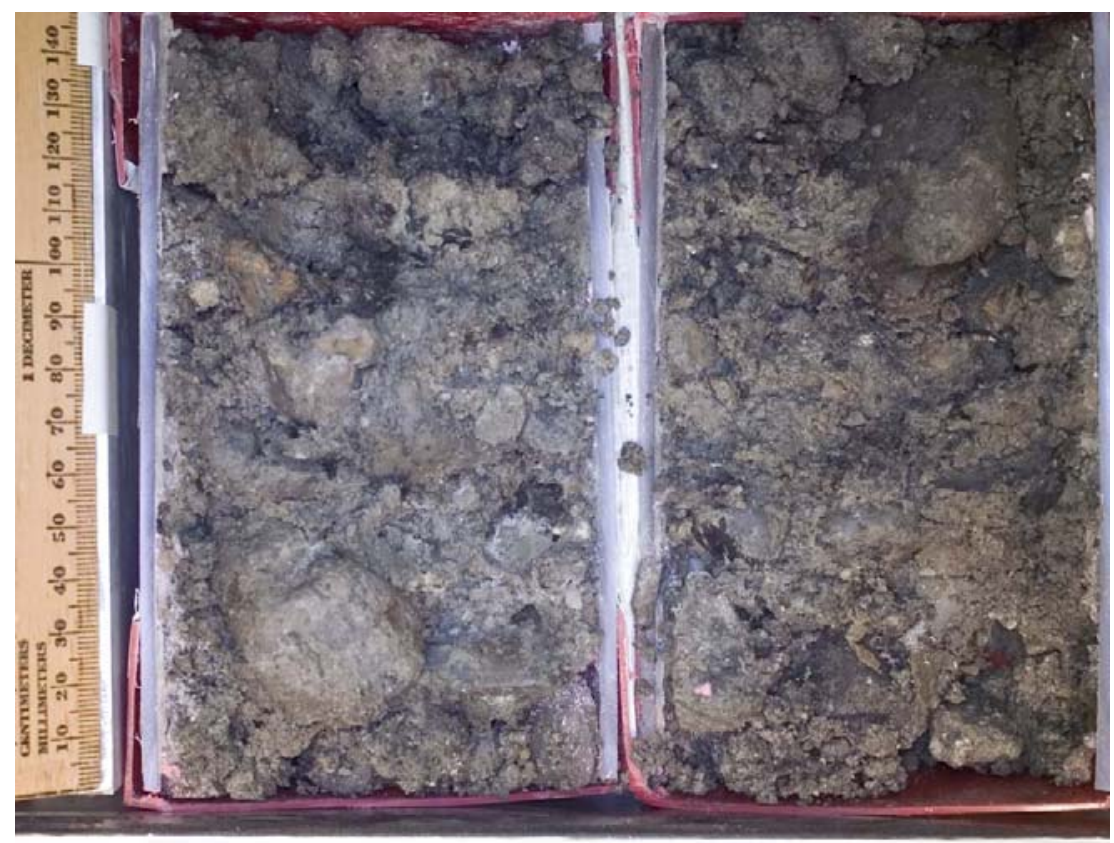

C5707 B1PL65

$$
\text { 39-42 ft LINER } 3 \text { UP } \uparrow
$$

Figure D.20. Photograph of Liner 3 from Sample B1PL65 from Borehole 399-4-14 


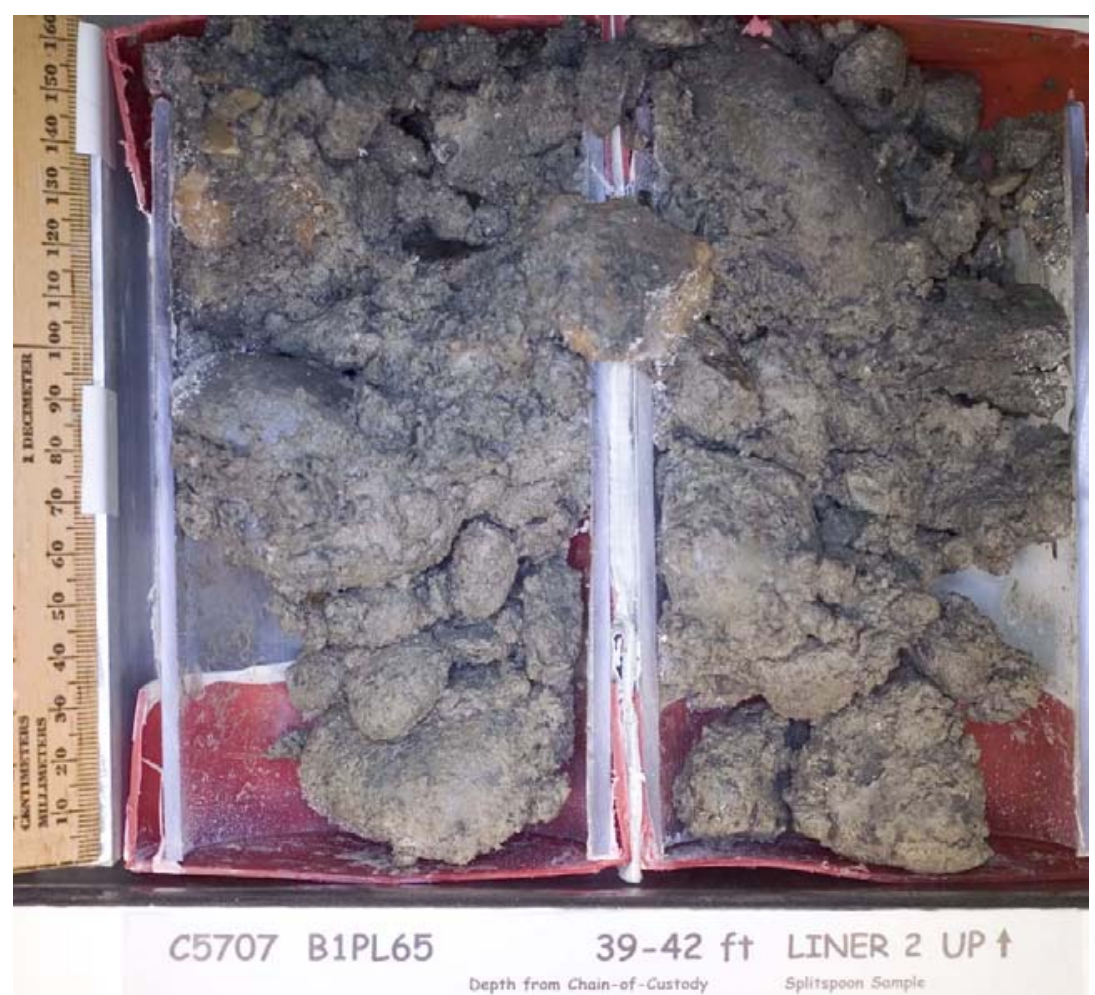

Figure D.21. Photograph of Liner 2 from Sample B1PL65 from Borehole 399-4-14

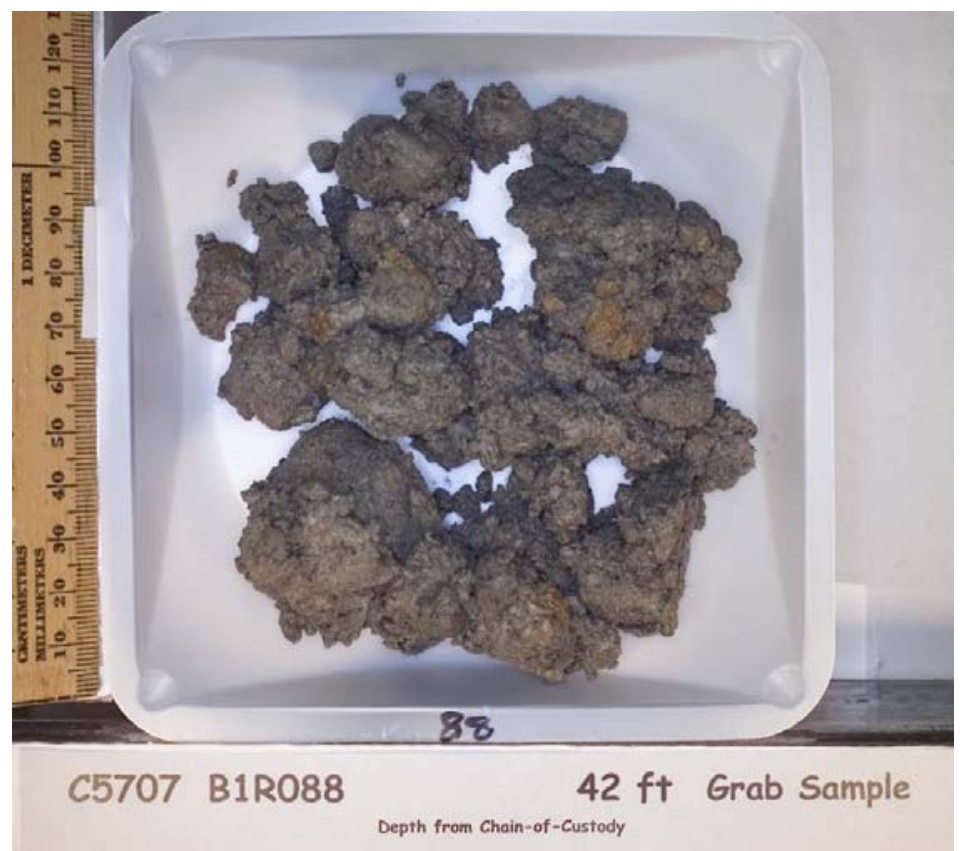

Figure D.22. Photograph of Grab Sample B1R088 from Borehole 399-4-14 


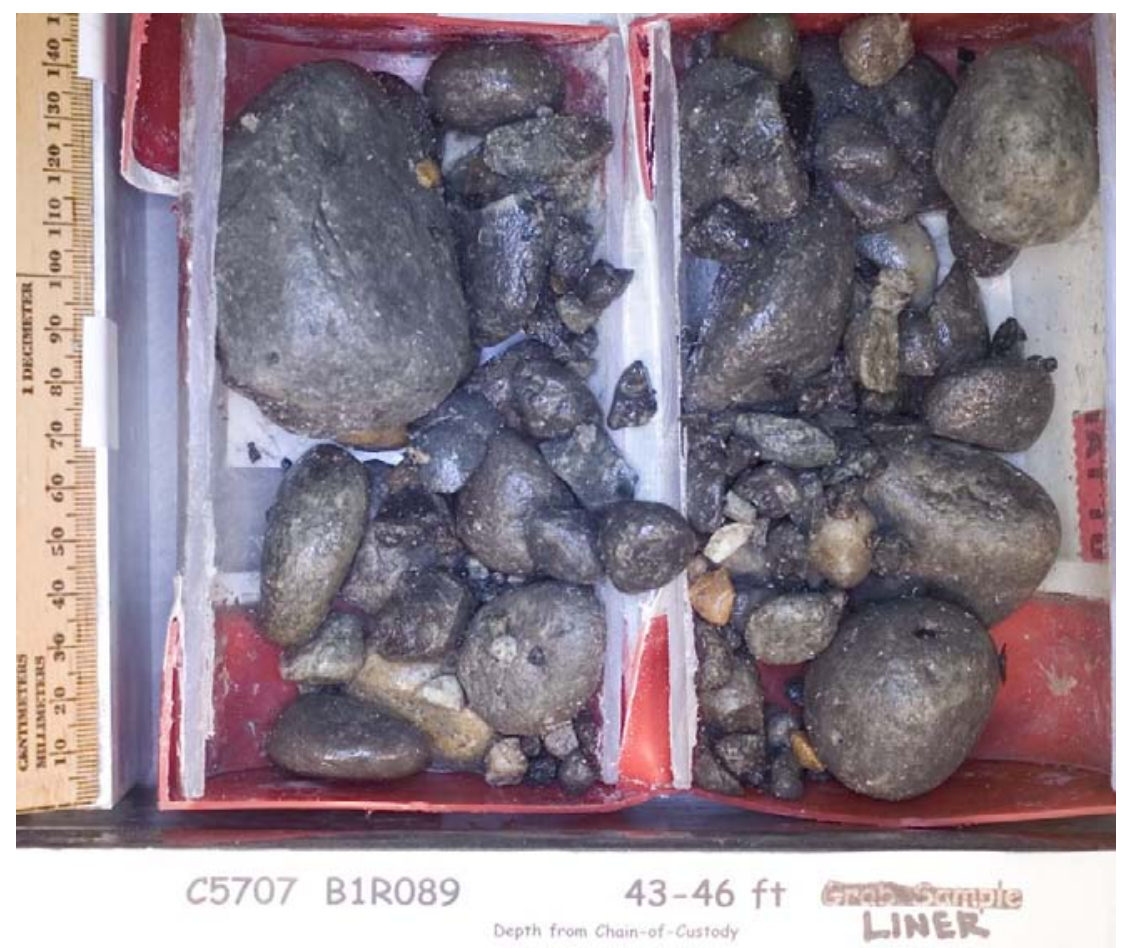

Figure D.23. Photograph of Liner from Sample B1R089 from Borehole 399-4-14

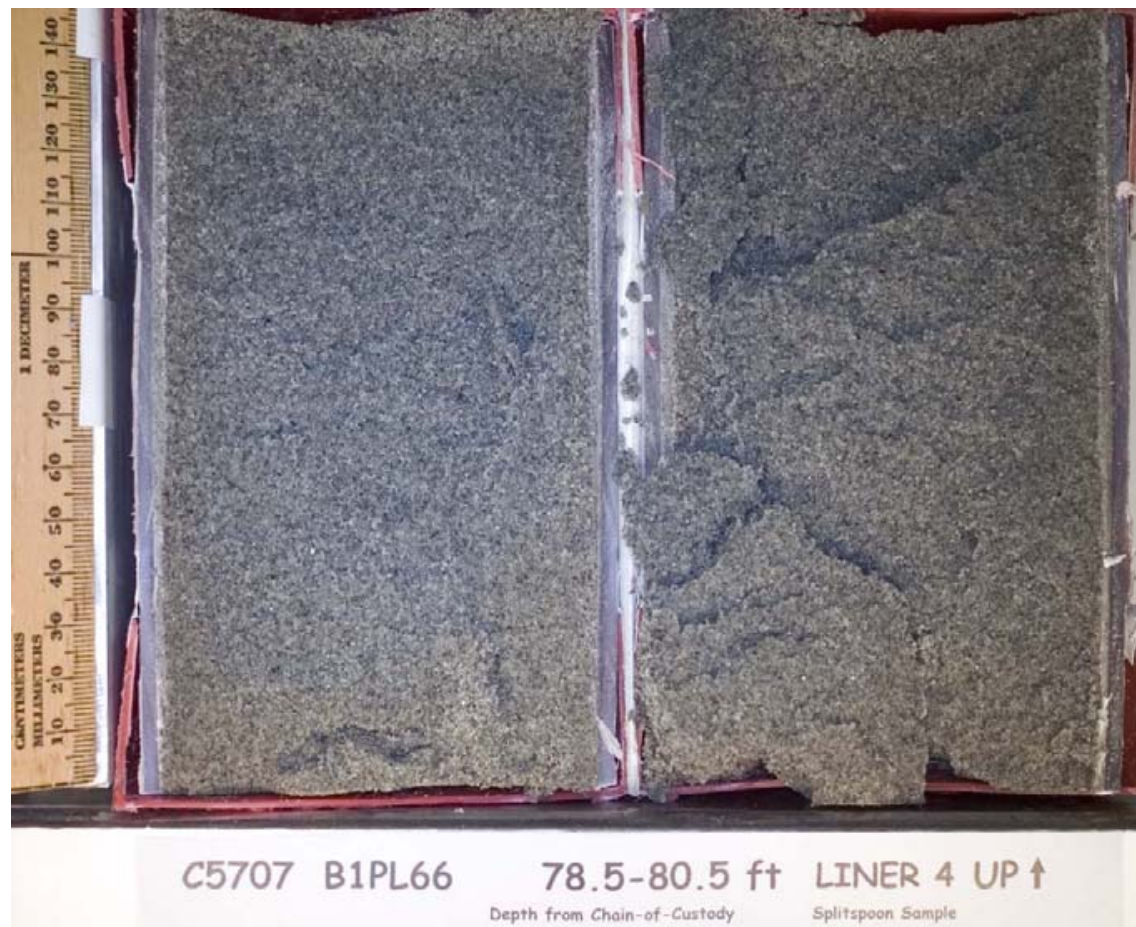

Figure D.24. Photograph of Liner 4 from Sample B1PL66 from Borehole 399-4-14 


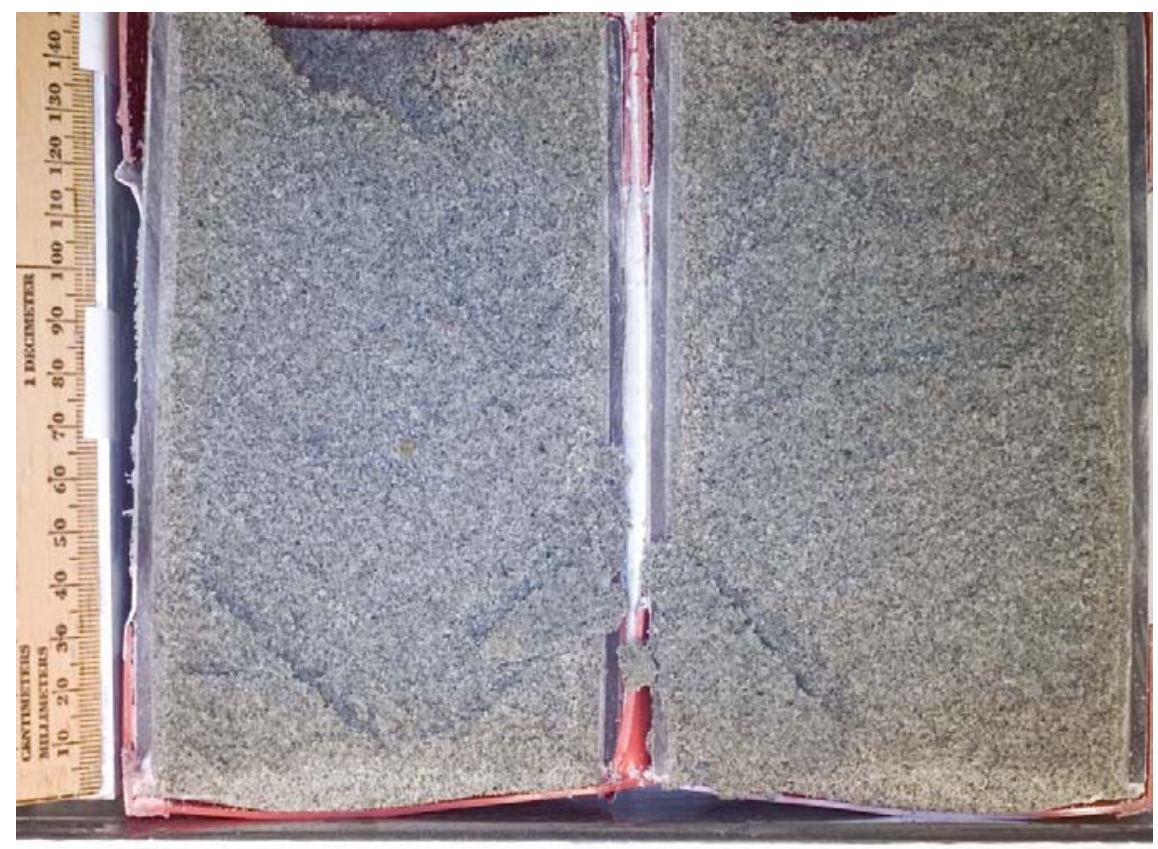

$$
\text { C5707 B1PL66 78.5-80.5 ft LINER } 3 \text { UP } \uparrow
$$

Figure D.25. Photograph of Liner 3 from Sample B1PL66 from Borehole 399-4-14

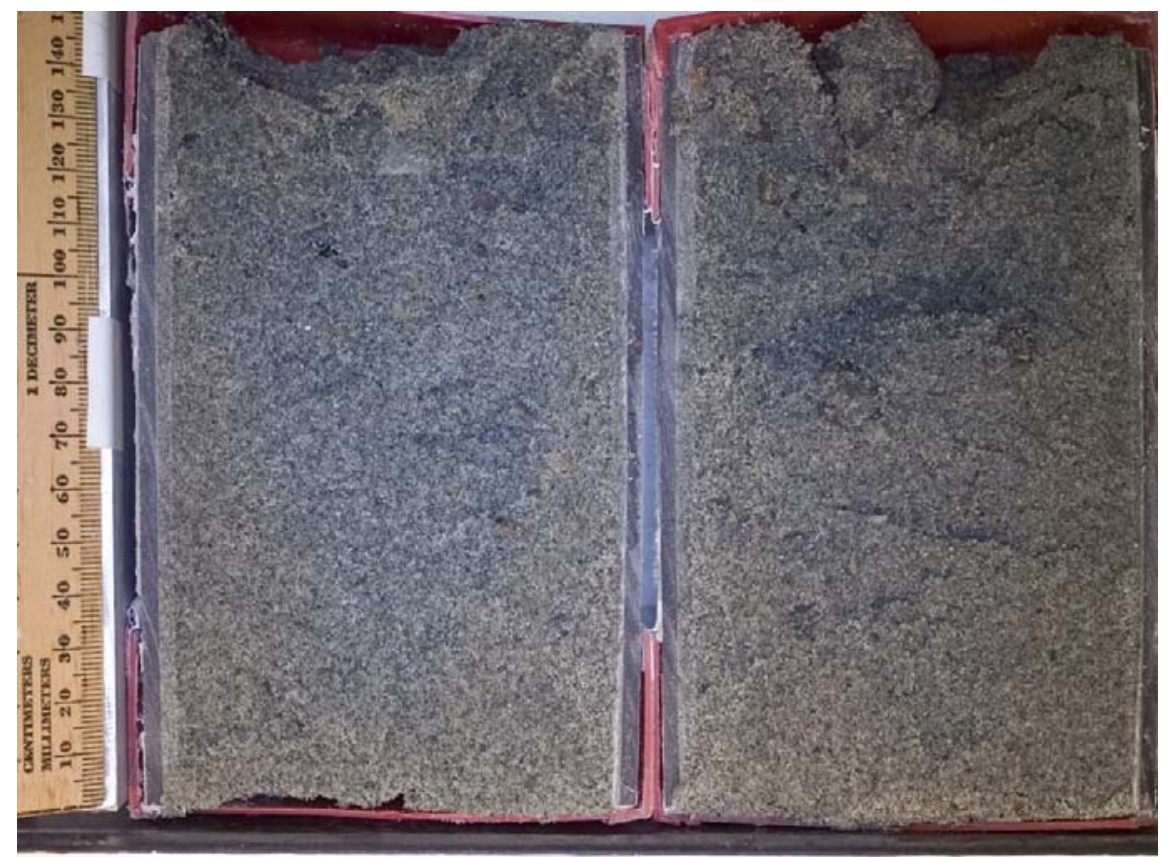

$$
\text { C5707 B1PL66 } 78.5-80.5 \mathrm{ft} \underset{\substack{\text { LINER } 2 \text { UP } \\ \text { Deplitspoon Sample }}}{\mathbf{L} \text { from Chain-of-Custody }}
$$

Figure D.26. Photograph of Liner 2 from Sample B1PL66 from Borehole 399-4-14 


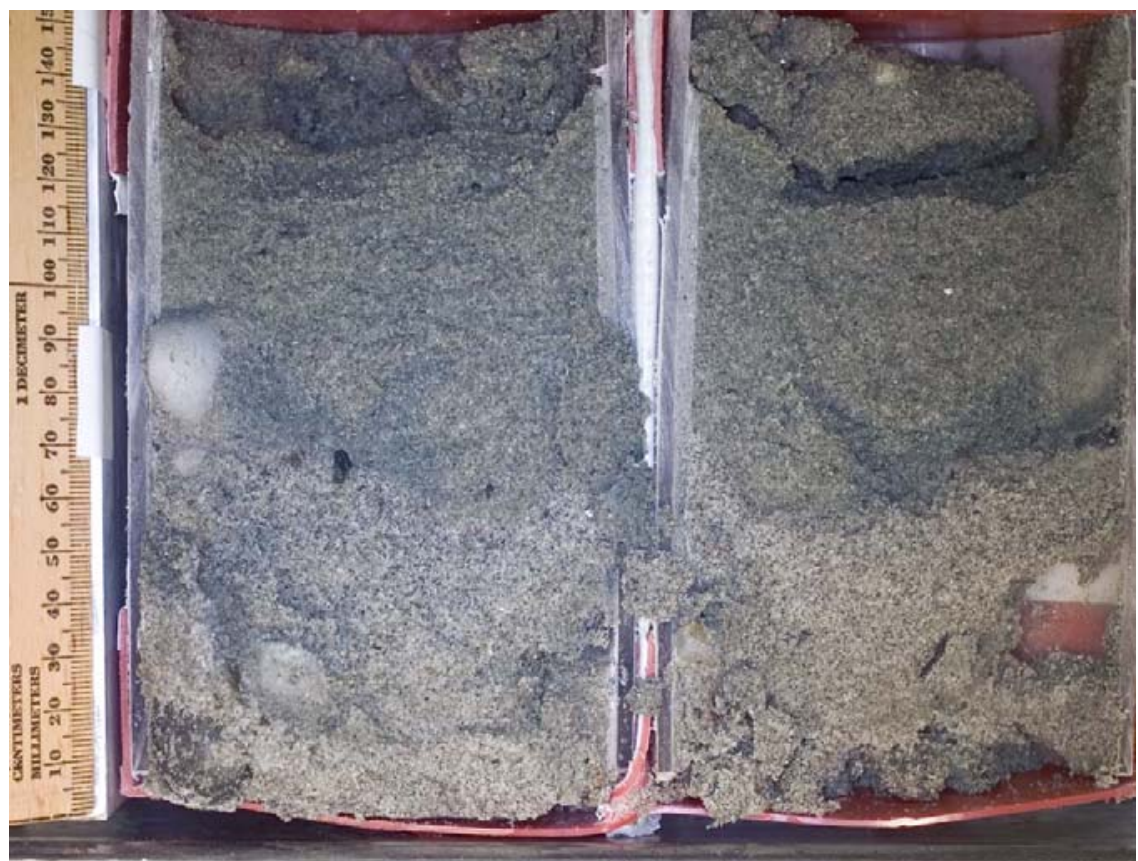

$$
\text { C5707 B1PL66 78.5-80.5 ft LINER } 1 \text { UP } \uparrow
$$

Figure D.27. Photograph of Liner 1 from Sample B1PL66 from Borehole 399-4-14 


\section{Appendix E}

Photographs of Samples Collected from Borehole C5706 



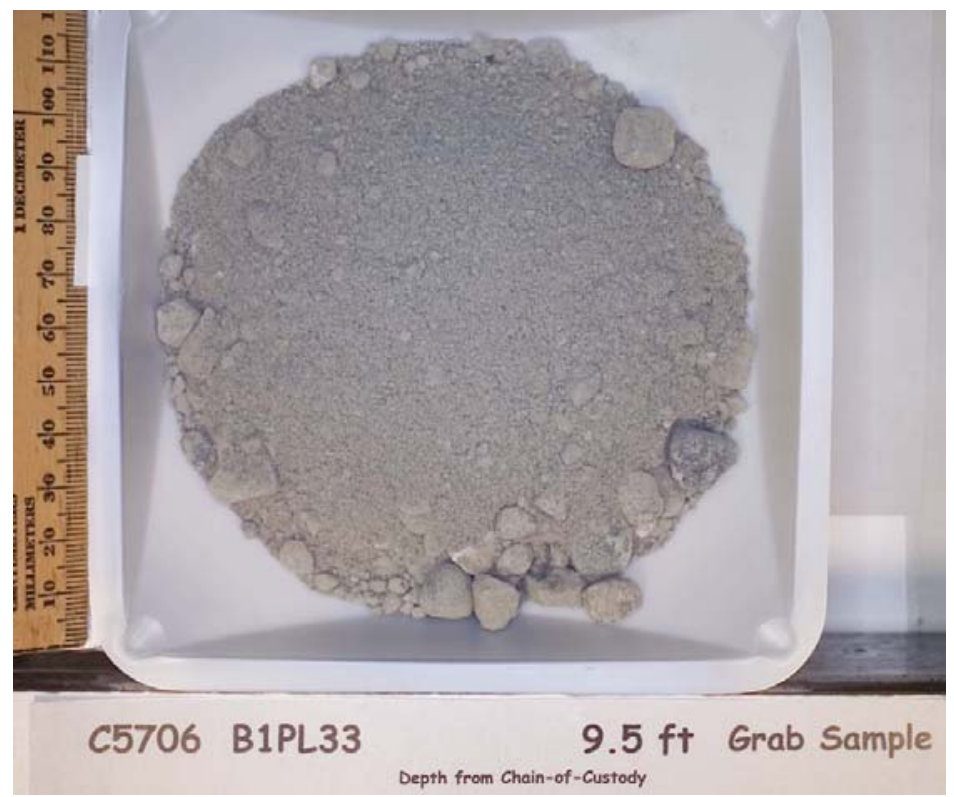

Figure E.1. Photograph of Grab Sample B1PL33 from Borehole 399-3-22

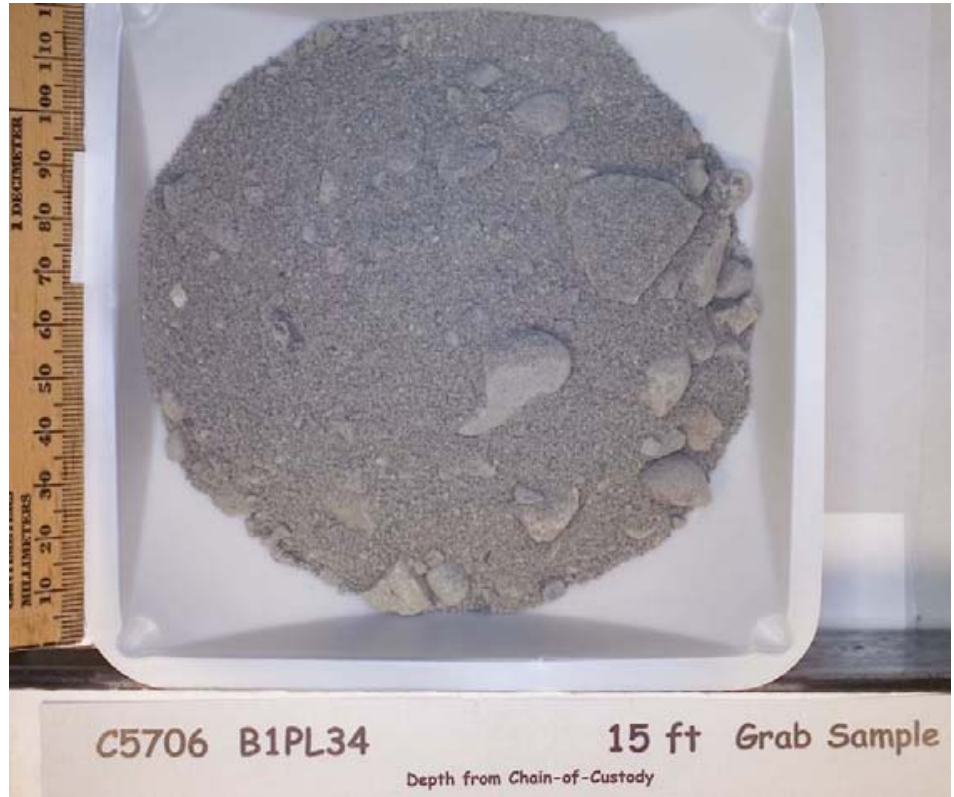

Figure E.2. Photograph of Grab Sample B1PL34 from Borehole 399-3-22 


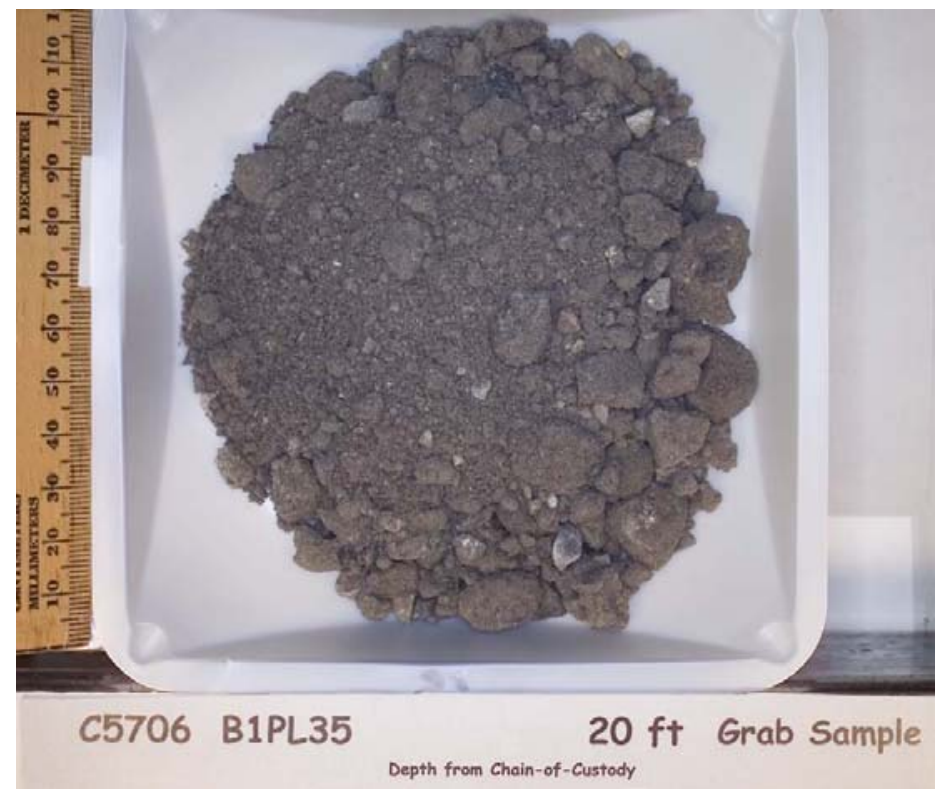

Figure E.3. Photograph of Grab Sample B1PL35 from Borehole 399-3-22

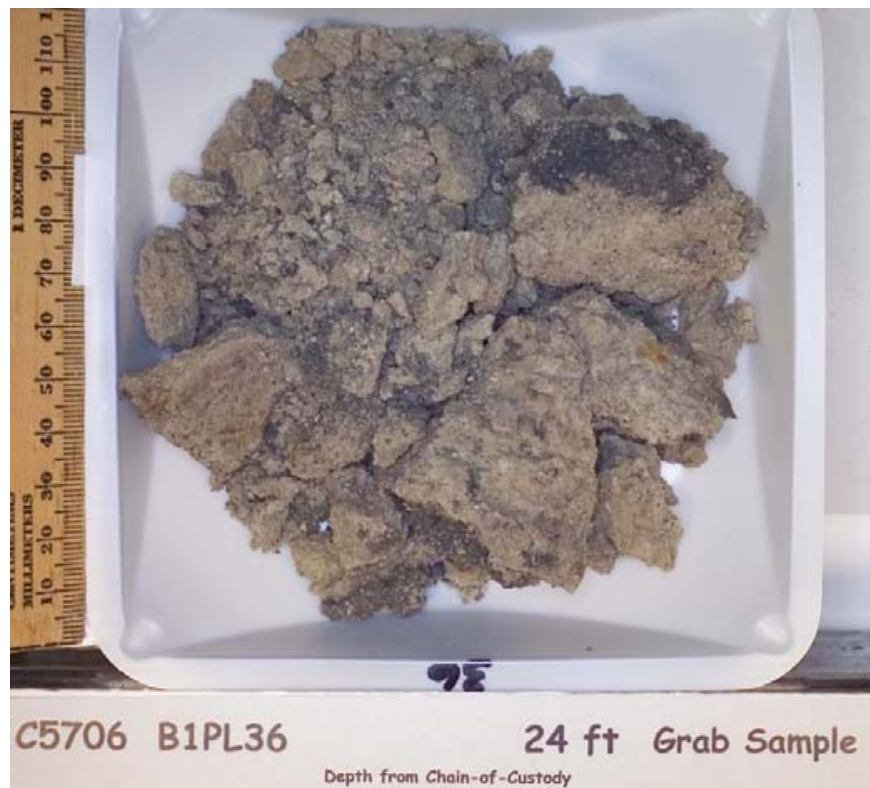

Figure E.4. Photograph of Grab Sample B1PL36 from Borehole 399-3-22 


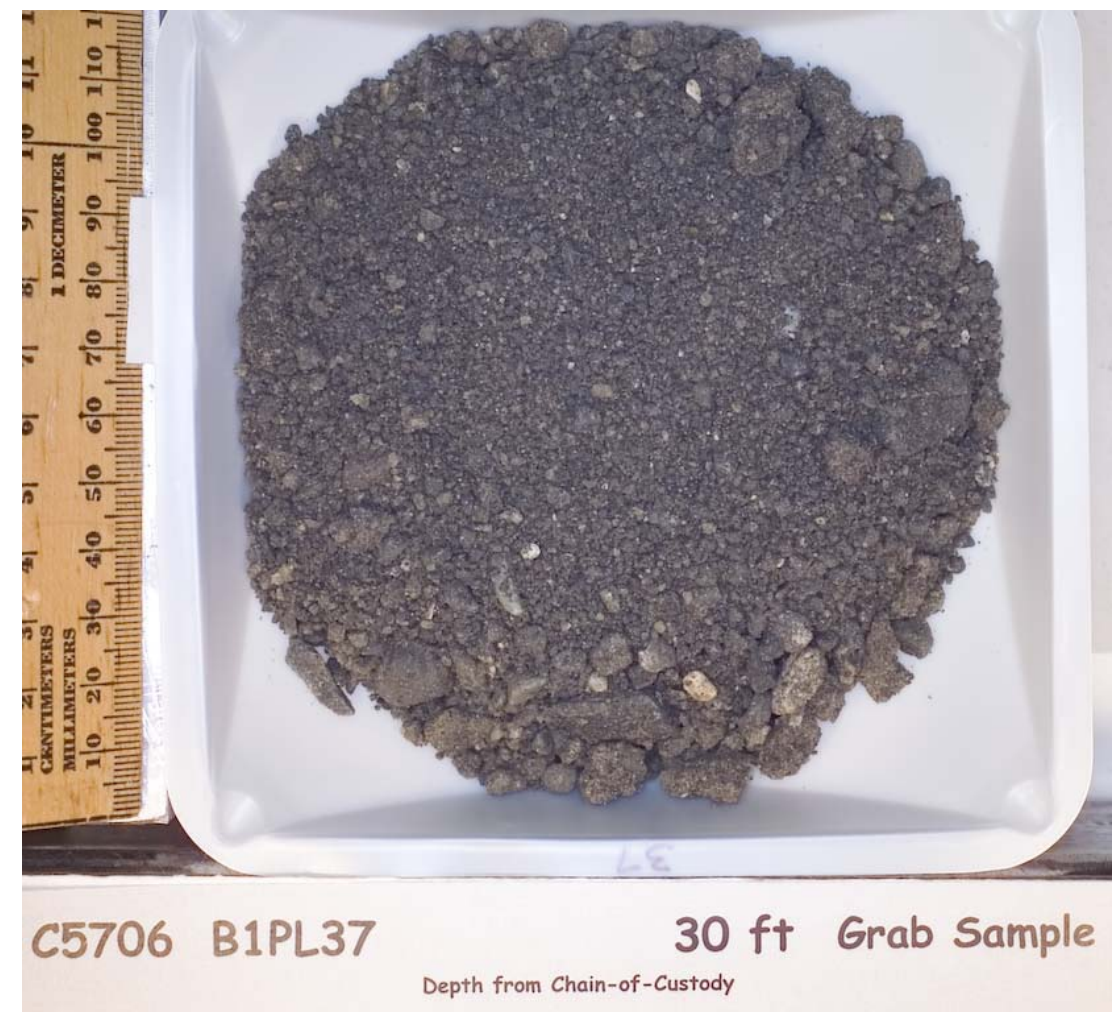

Figure E.5. Photograph of Grab Sample B1PL37 from Borehole 399-3-22

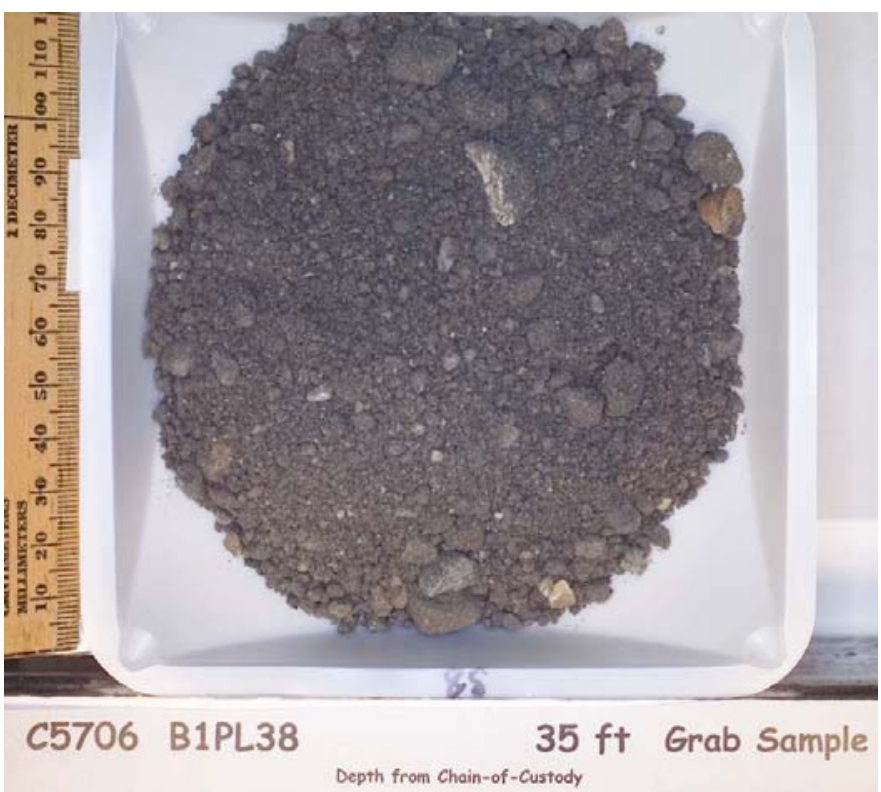

Figure E.6. Photograph of Grab Sample B1PL38 from Borehole 399-3-22 


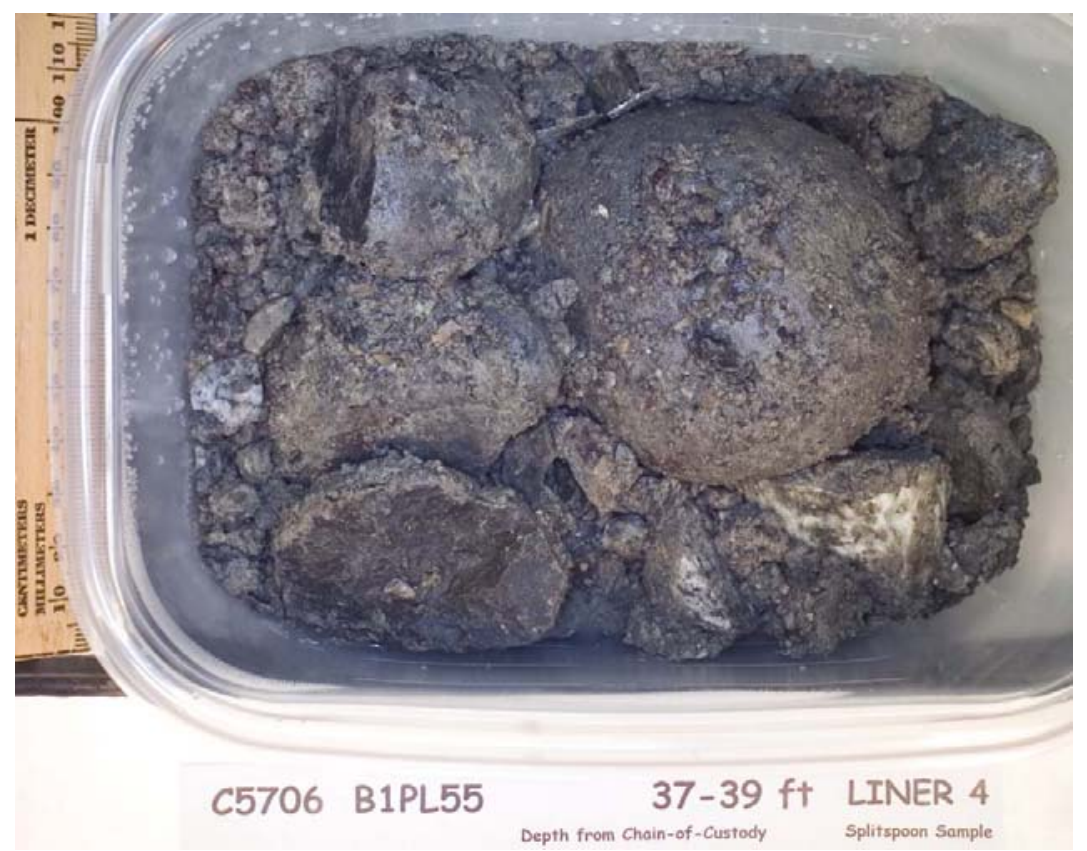

Figure E.7. Photograph of Liner 4 from Sample B1PL55 from Borehole 399-3-22

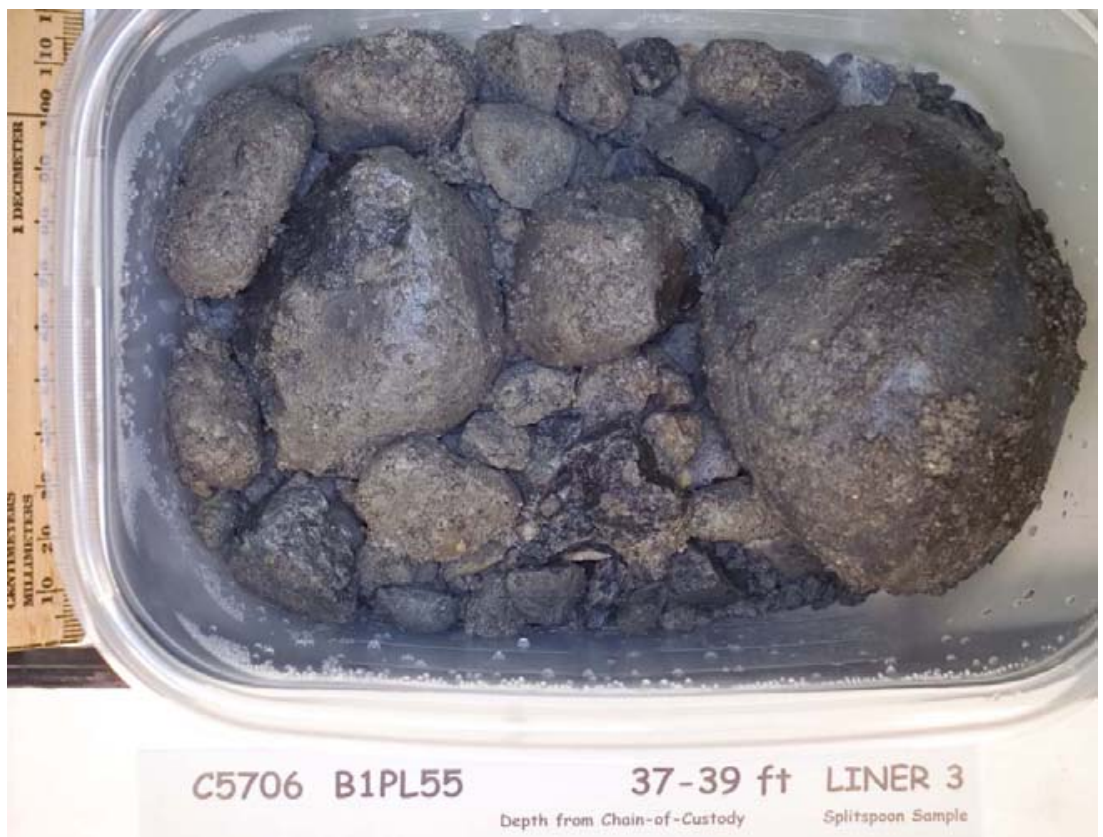

Figure E.8. Photograph of Liner 3 from Sample B1PL55 from Borehole 399-3-22 


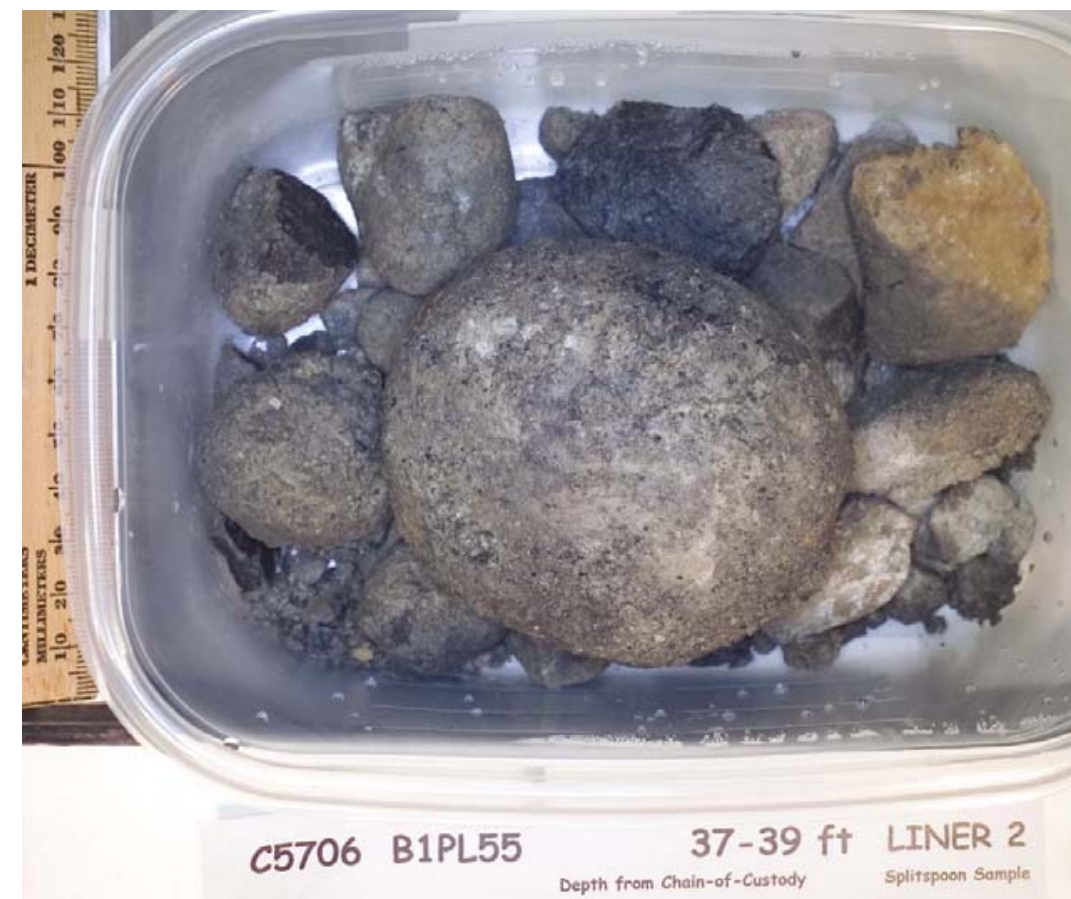

Figure E.9. Photograph of Liner 2 from Sample B1PL55 from Borehole 399-3-22

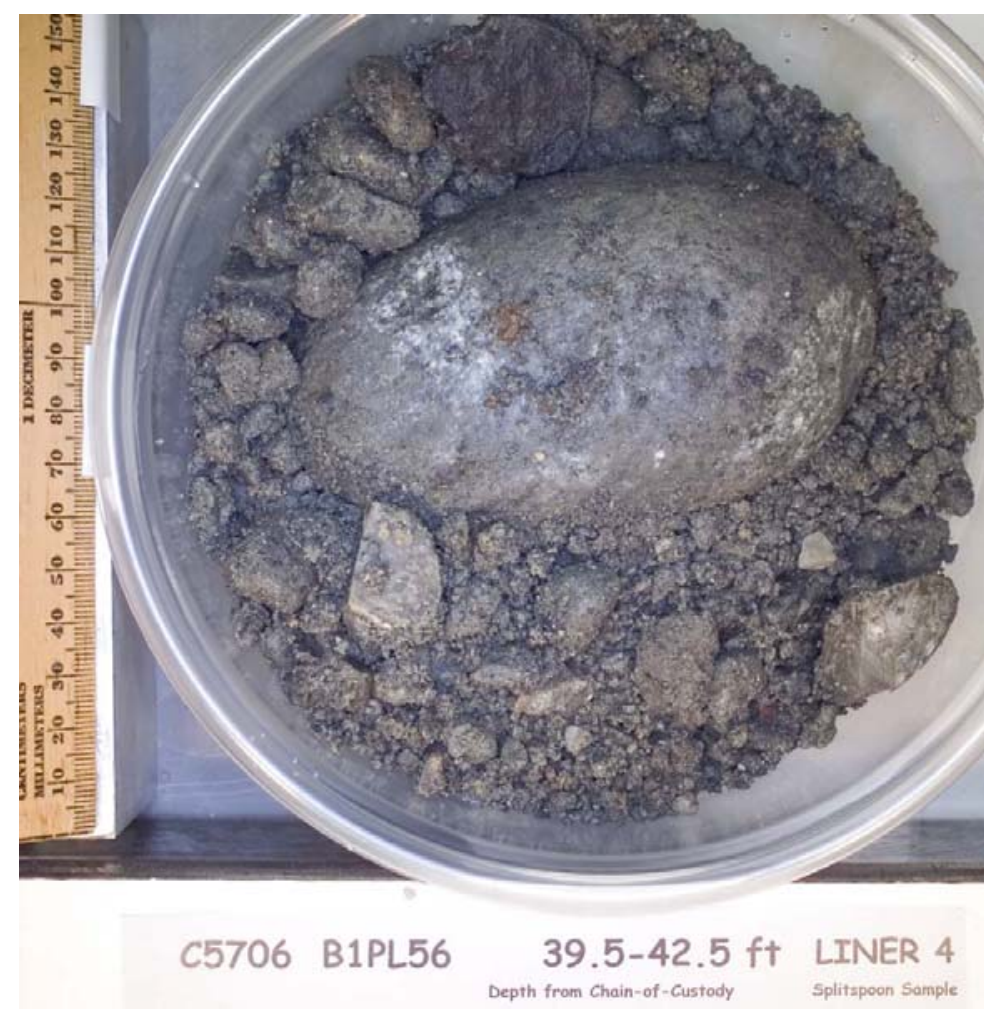

Figure E.10. Photograph of Liner 4 from Sample B1PL56 from Borehole 399-3-22 


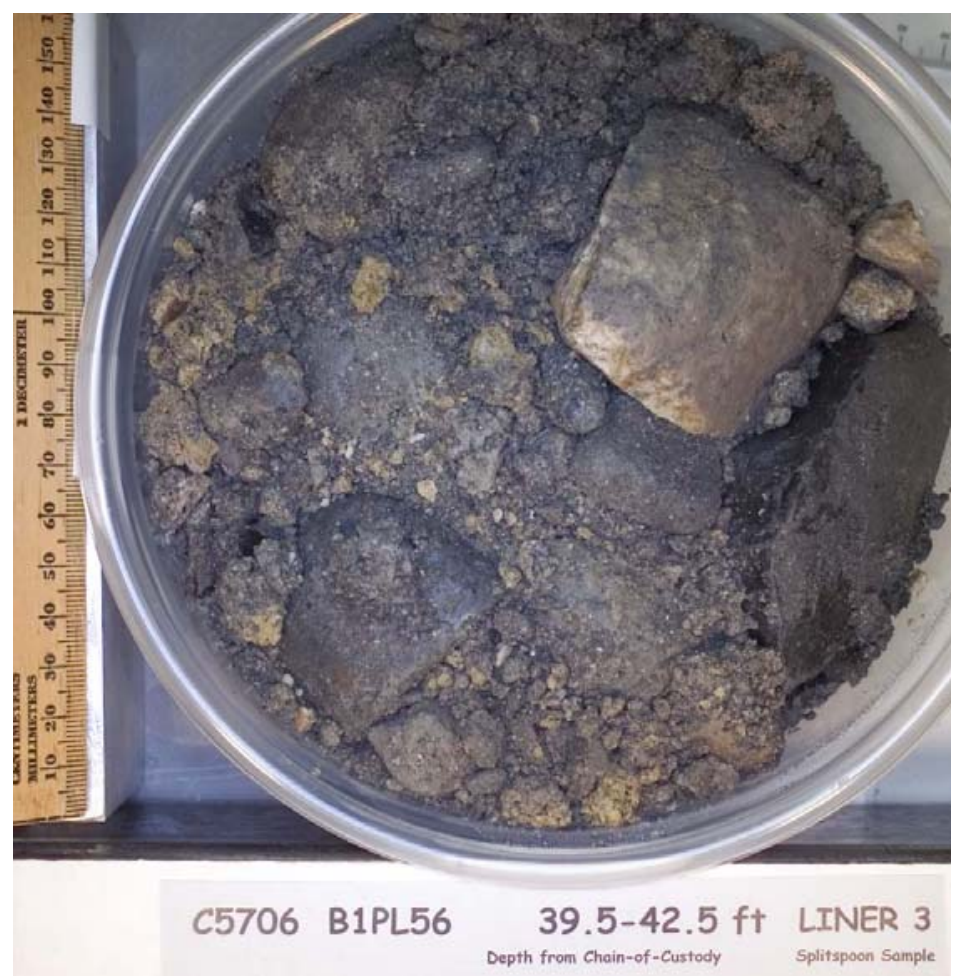

Figure E.11. Photograph of Liner 3 from Sample B1PL56 from Borehole 399-3-22

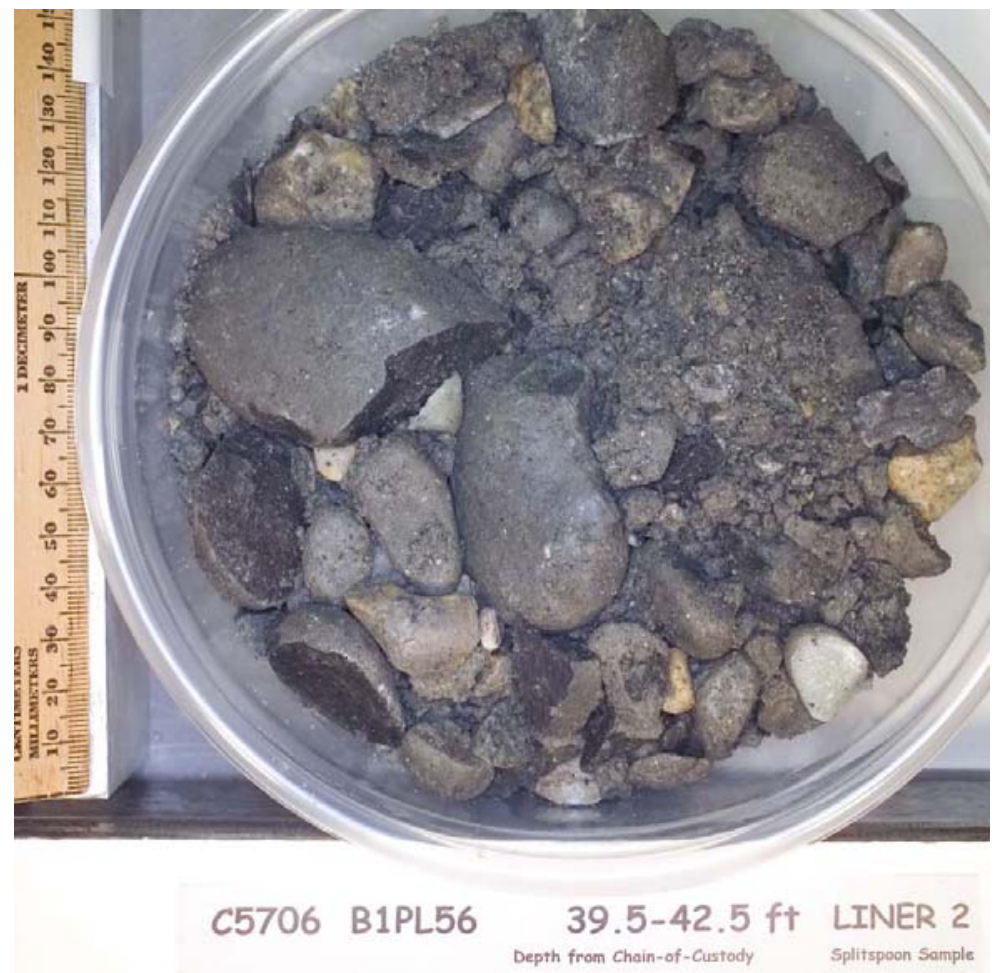

Figure E.12. Photograph of Liner 2 from Sample B1PL56 from Borehole 399-3-22 


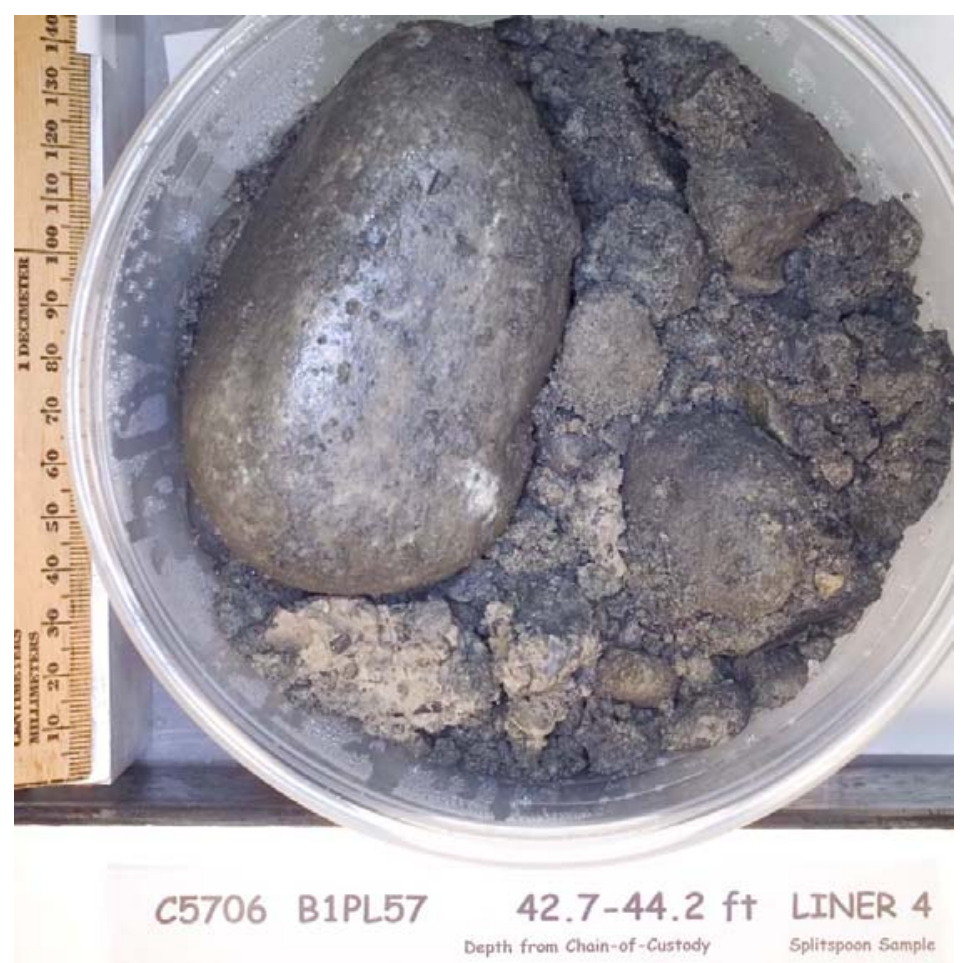

Figure E.13. Photograph of Liner 4 from Sample B1PL57 from Borehole 399-3-22

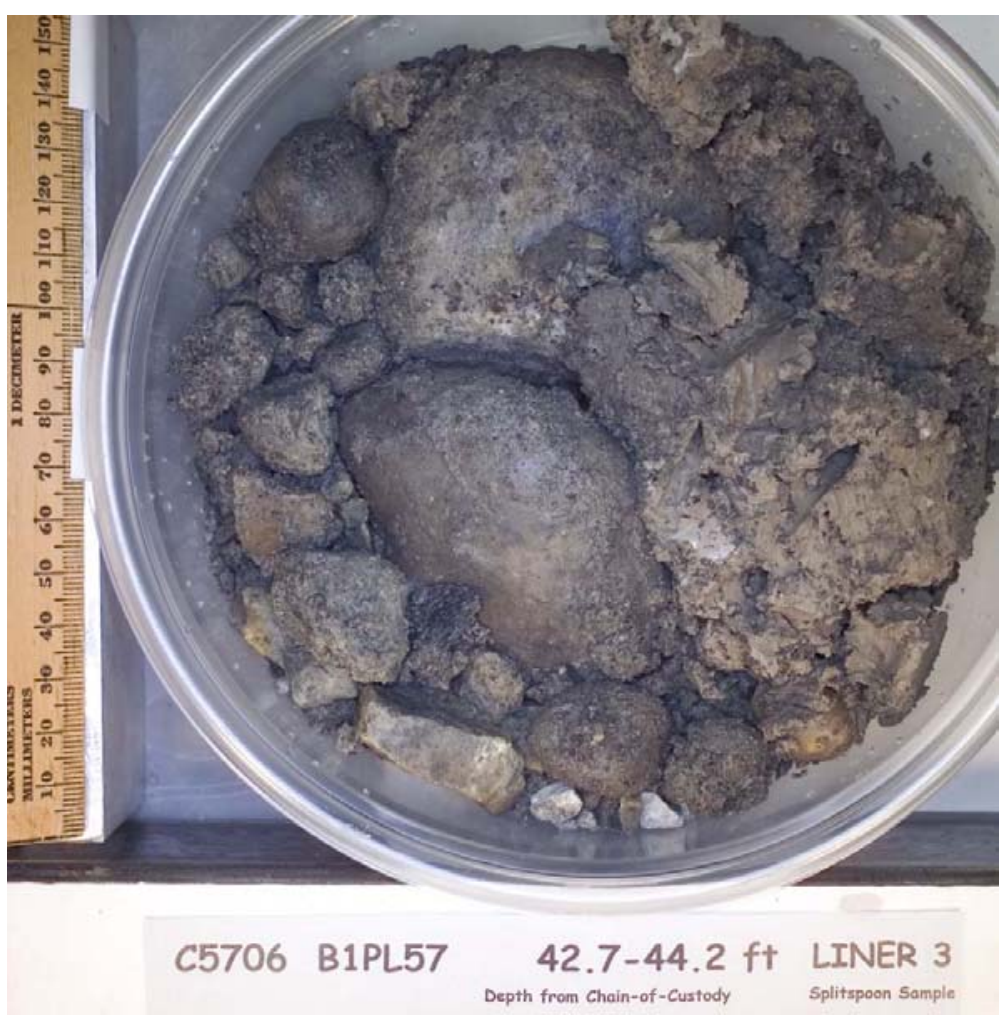

Figure E.14. Photograph of Liner 3 from Sample B1PL57 from Borehole 399-3-22 


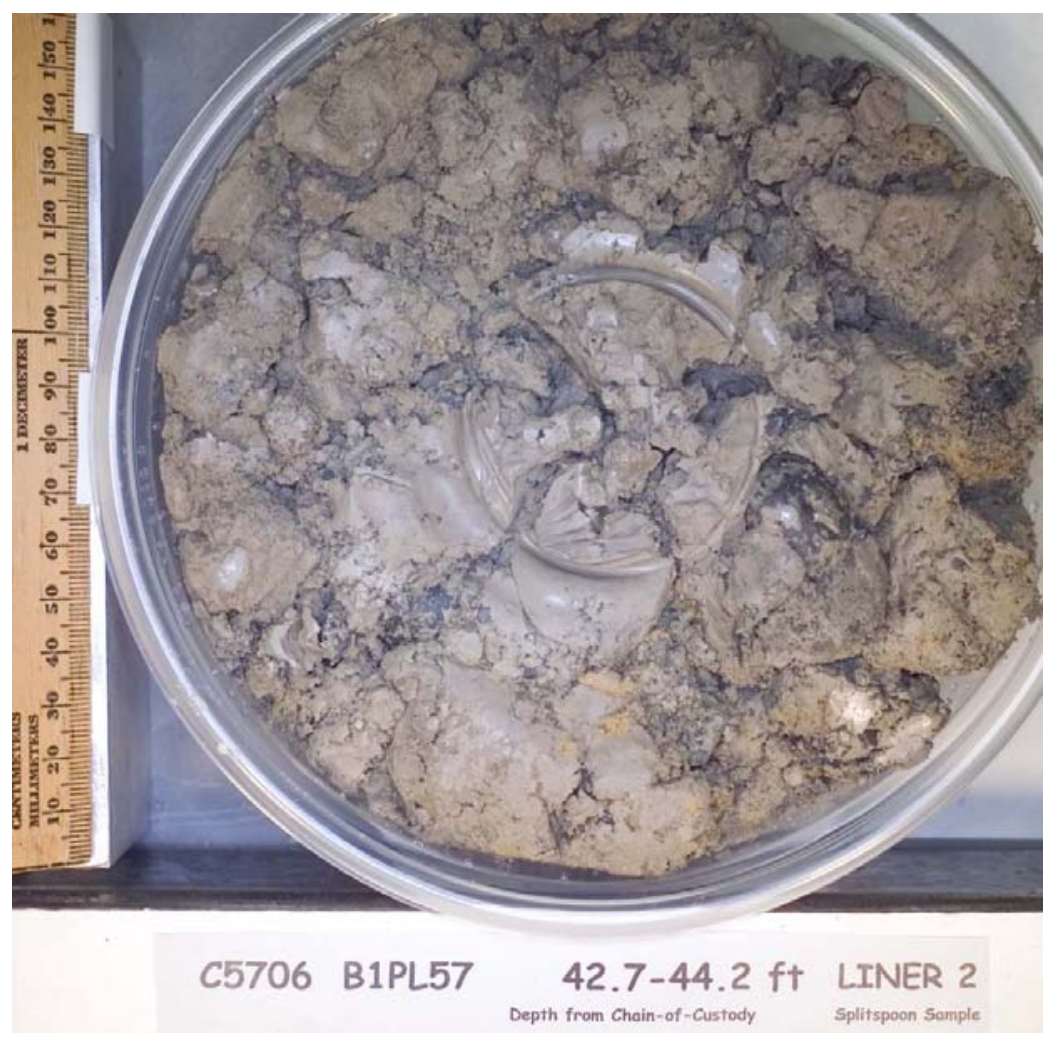

Figure E.15. Photograph of Liner 2 from Sample B1PL57 from Borehole 399-3-22

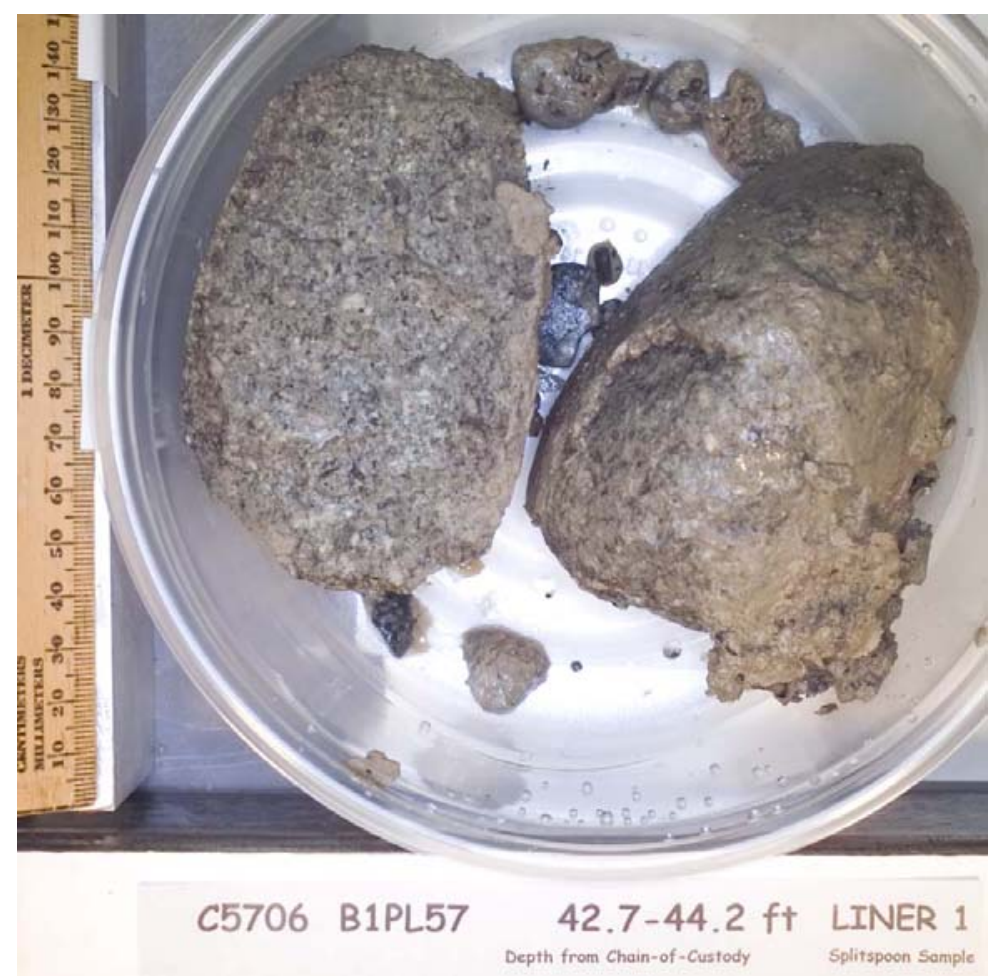

Figure E.16. Photograph of Liner 1 from Sample B1PL57 from Borehole 399-3-22 

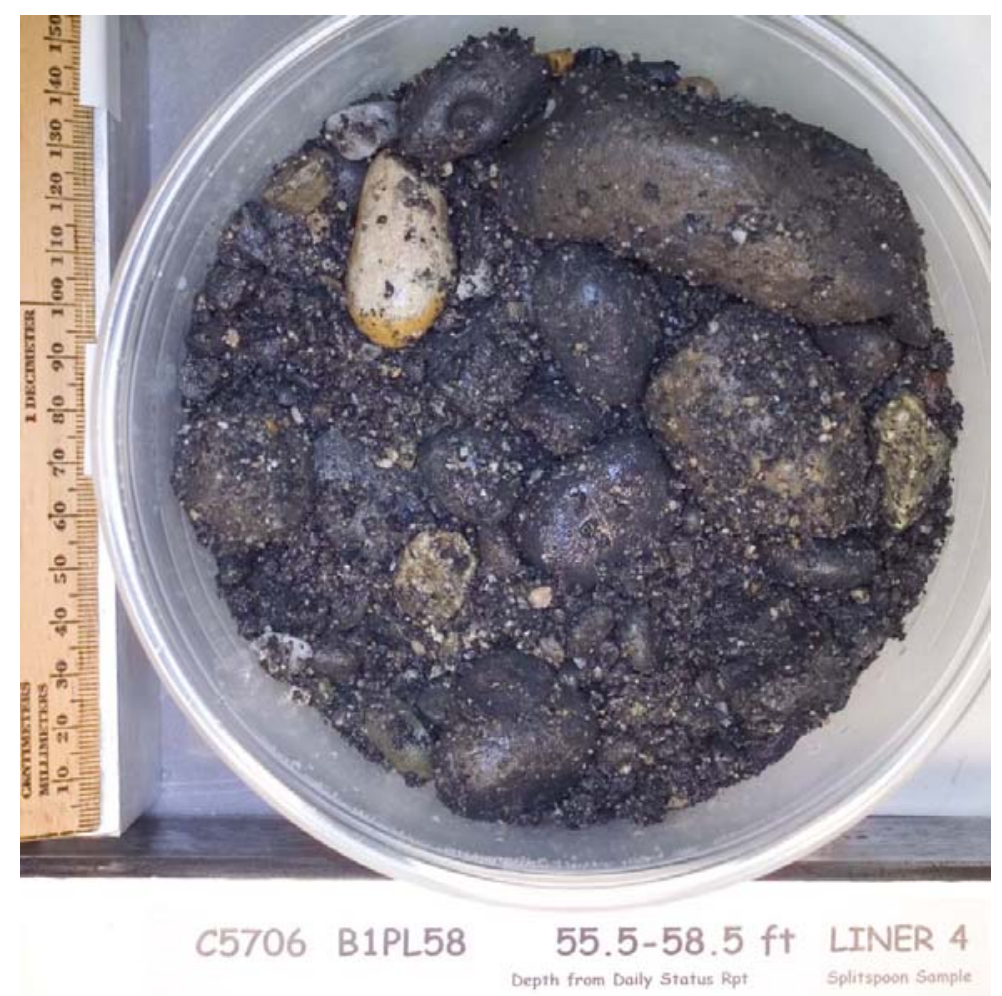

Figure E.17. Photograph of Liner 4 from Sample B1PL58 from Borehole 399-3-22

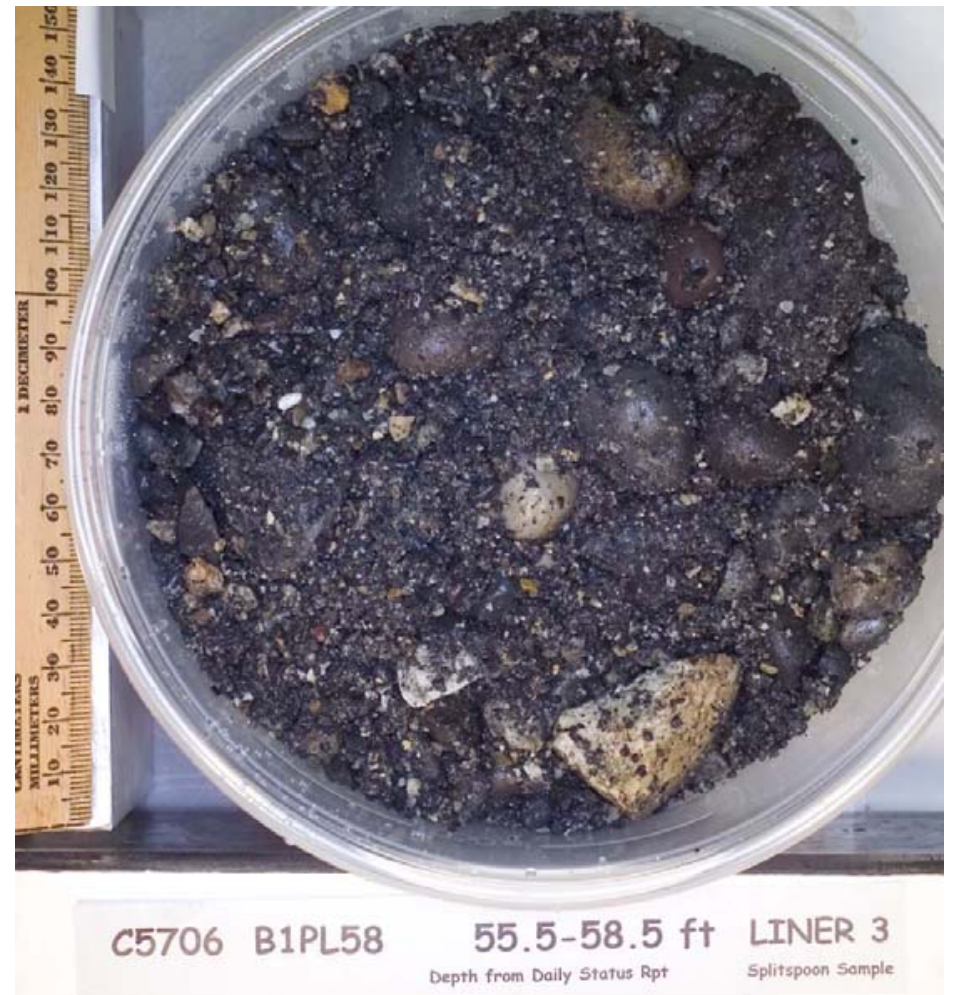

Figure E.18. Photograph of Liner 3 from Sample B1PL58 from Borehole 399-3-22 


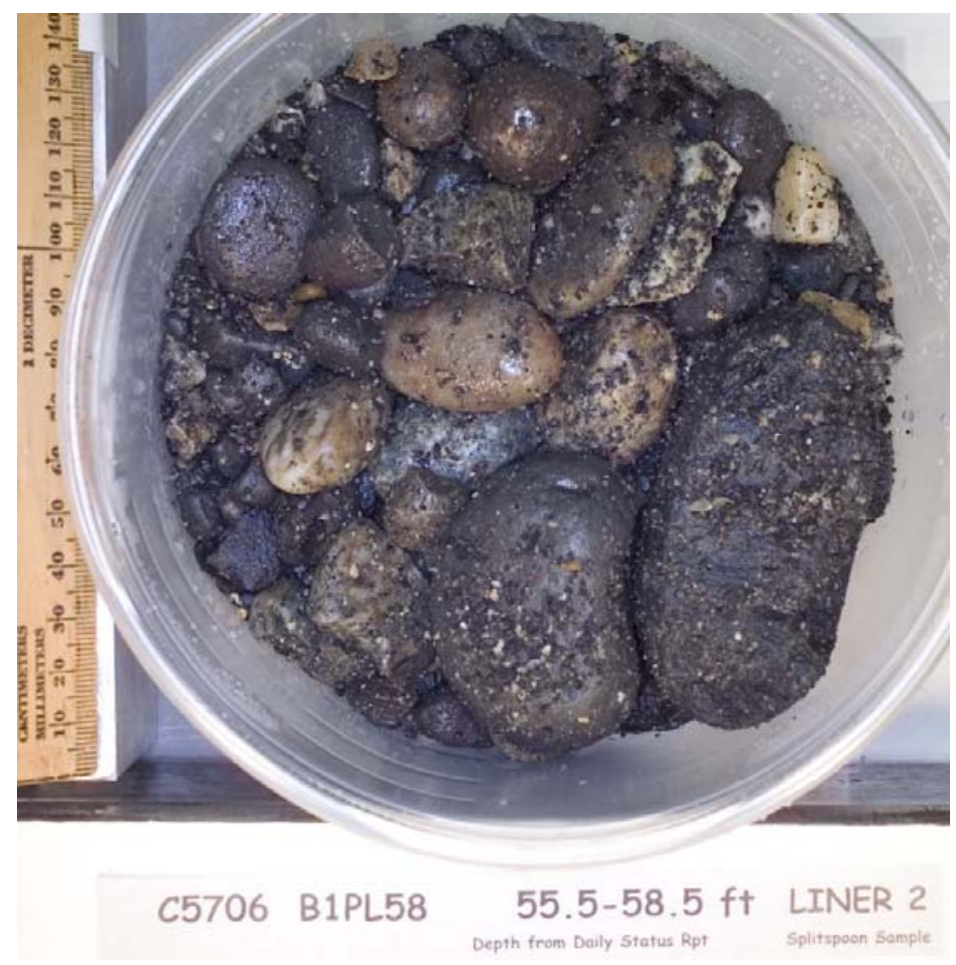

Figure E.19. Photograph of Liner 2 from Sample B1PL58 from Borehole 399-3-22

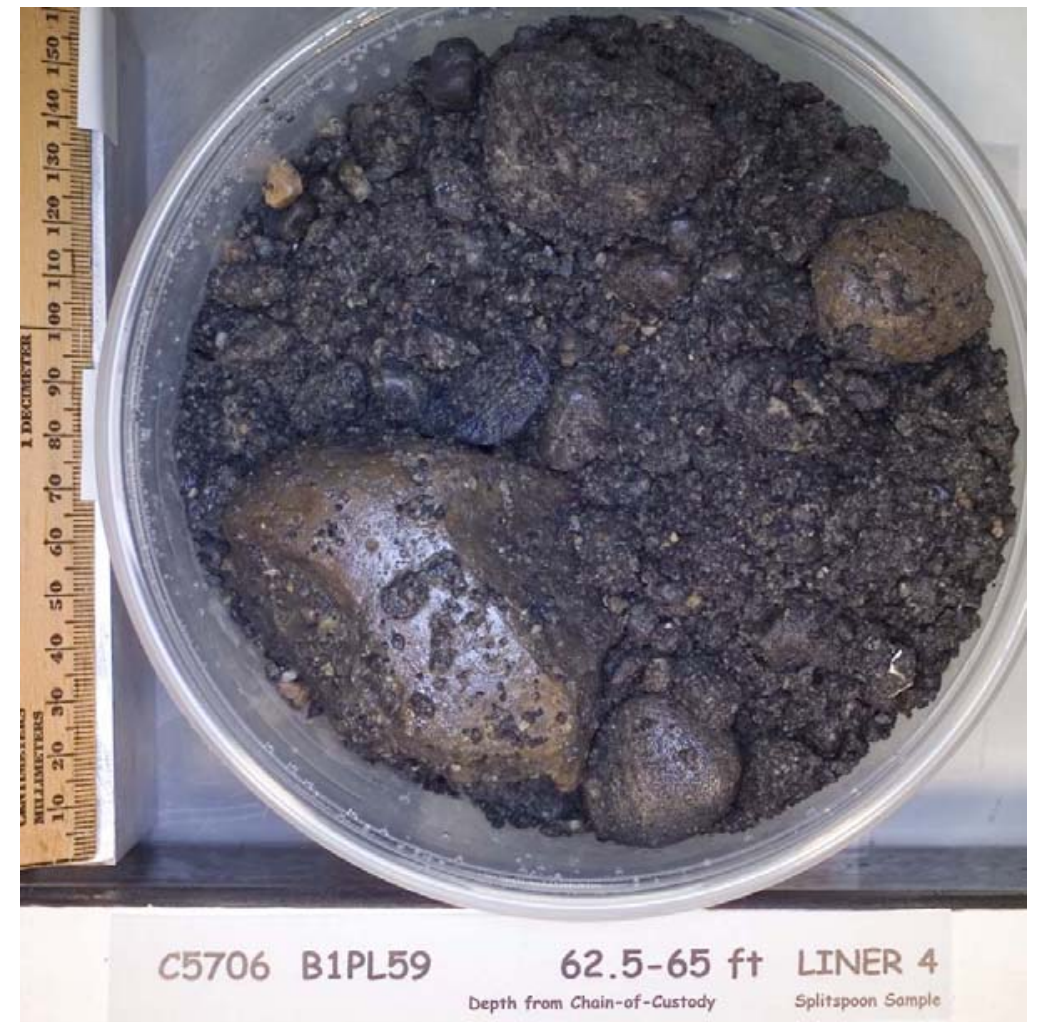

Figure E.20. Photograph of Liner 4 from Sample B1PL59 from Borehole 399-3-22 

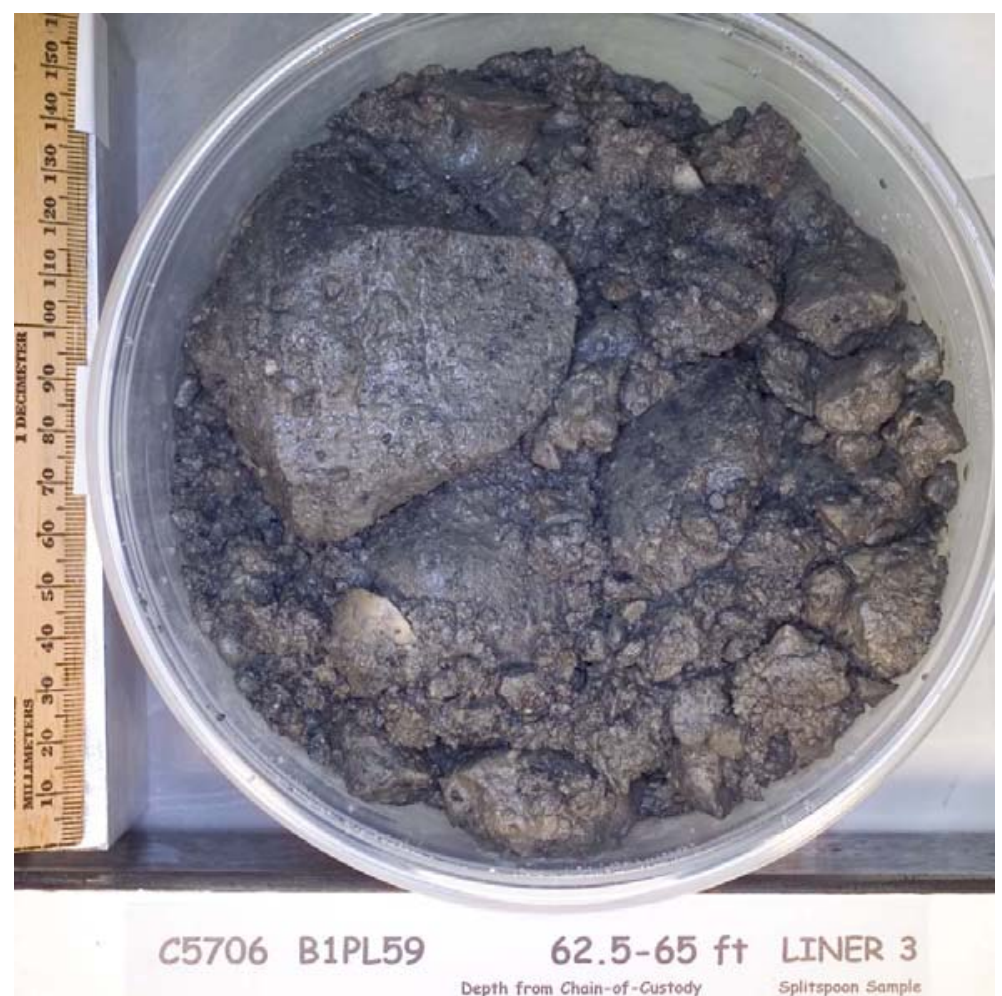

Figure E.21. Photograph of Liner 3 from Sample B1PL59 from Borehole 399-3-22

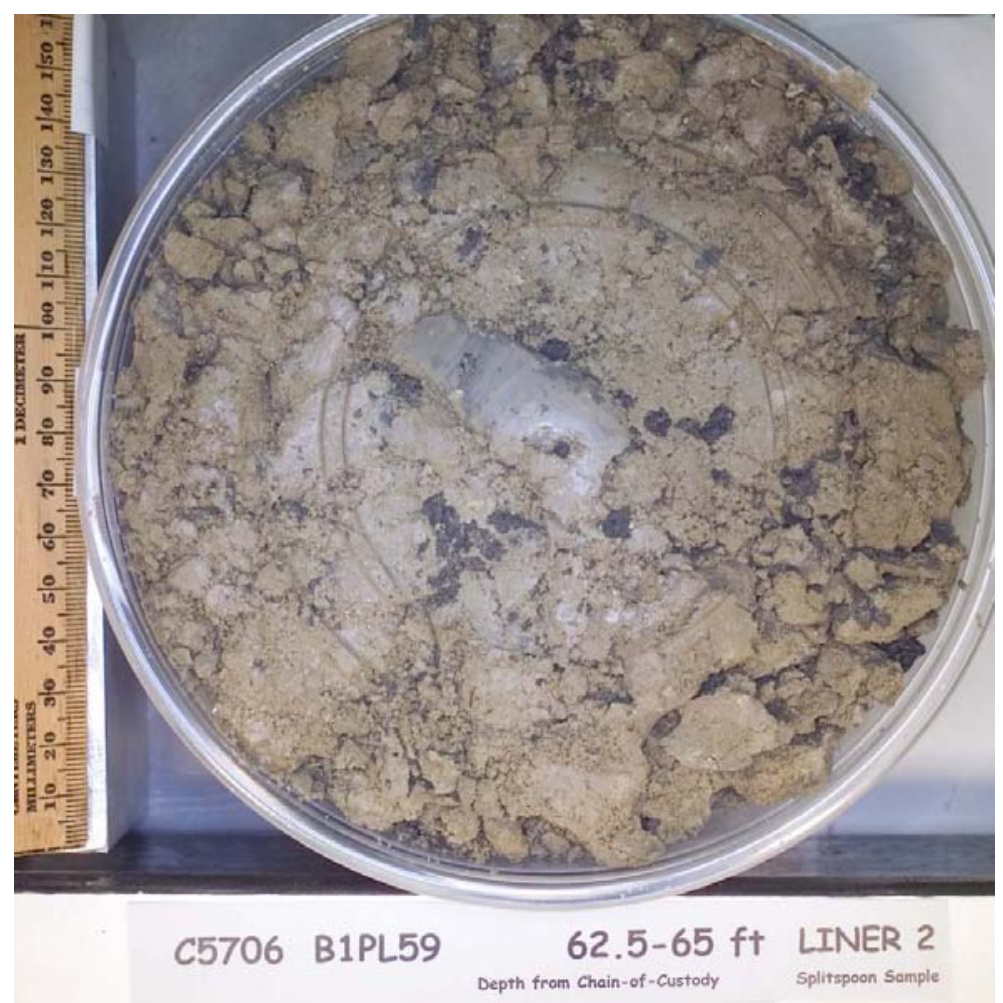

Figure E.22. Photograph of Liner 2 from Sample B1PL59 from Borehole 399-3-22 


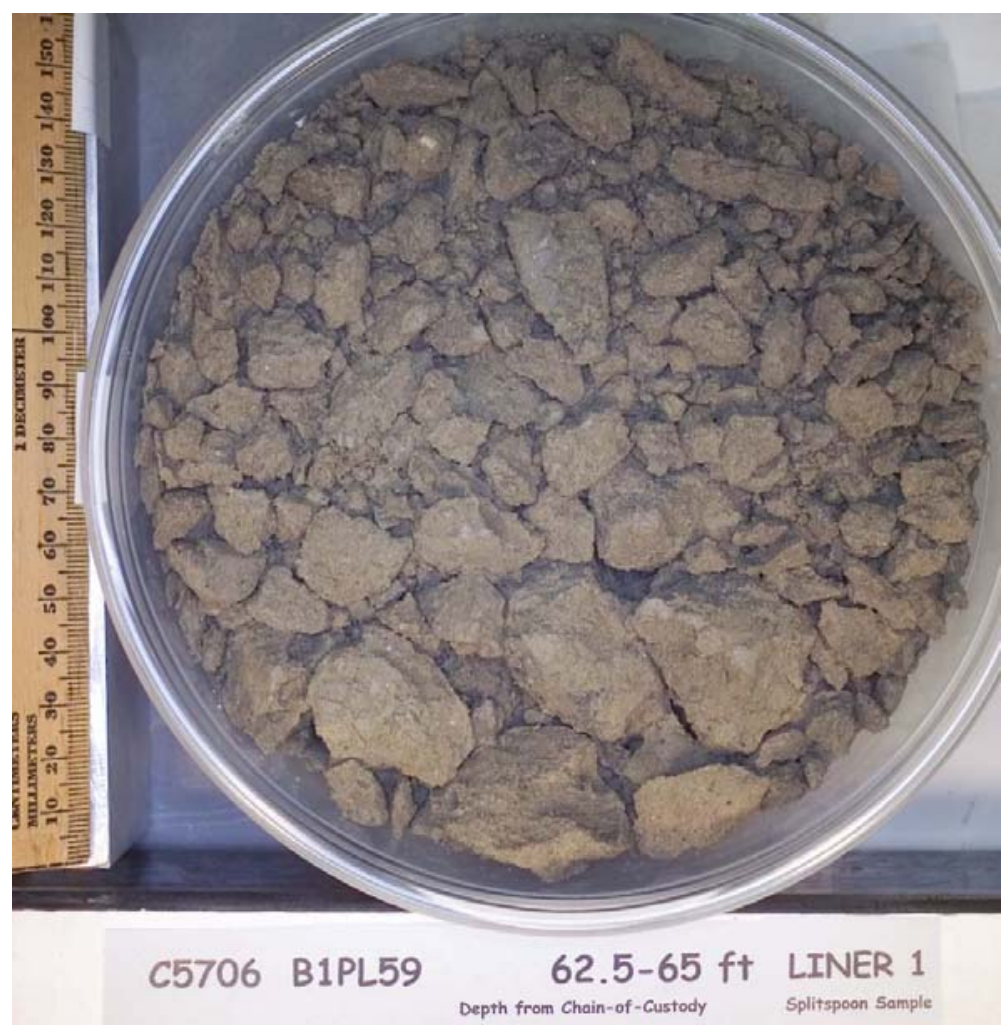

Figure E.23. Photograph of Liner 1 from Sample B1PL59 from Borehole 399-3-22

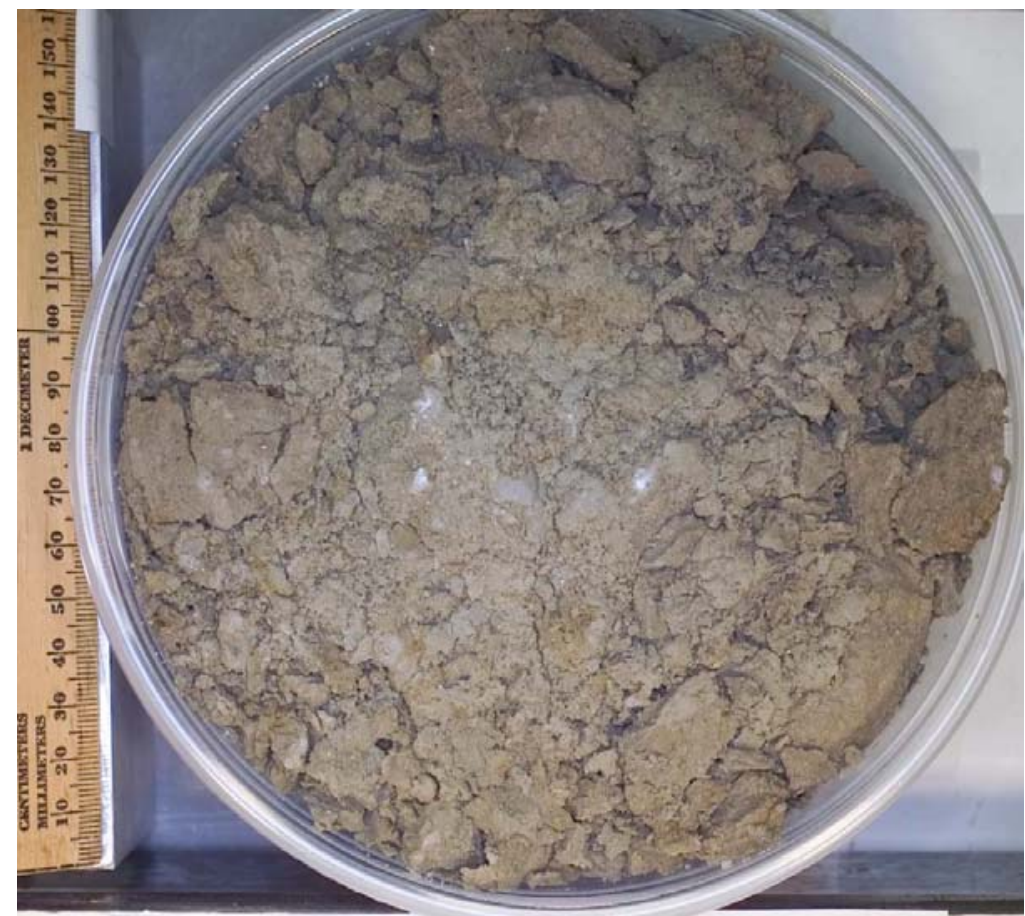

$$
\text { C5706 B1PL60 } \underset{\substack{\text { Depth from Chain-of-Custody } \\
\text { Splitspoon Sample }}}{65.3-67.8 \mathrm{ft}} \quad \begin{aligned}
& \text { LINER } 4 \\
& \text { B. }
\end{aligned}
$$

Figure E.24. Photograph of Liner 4 from Sample B1PL60 from Borehole 399-3-22 


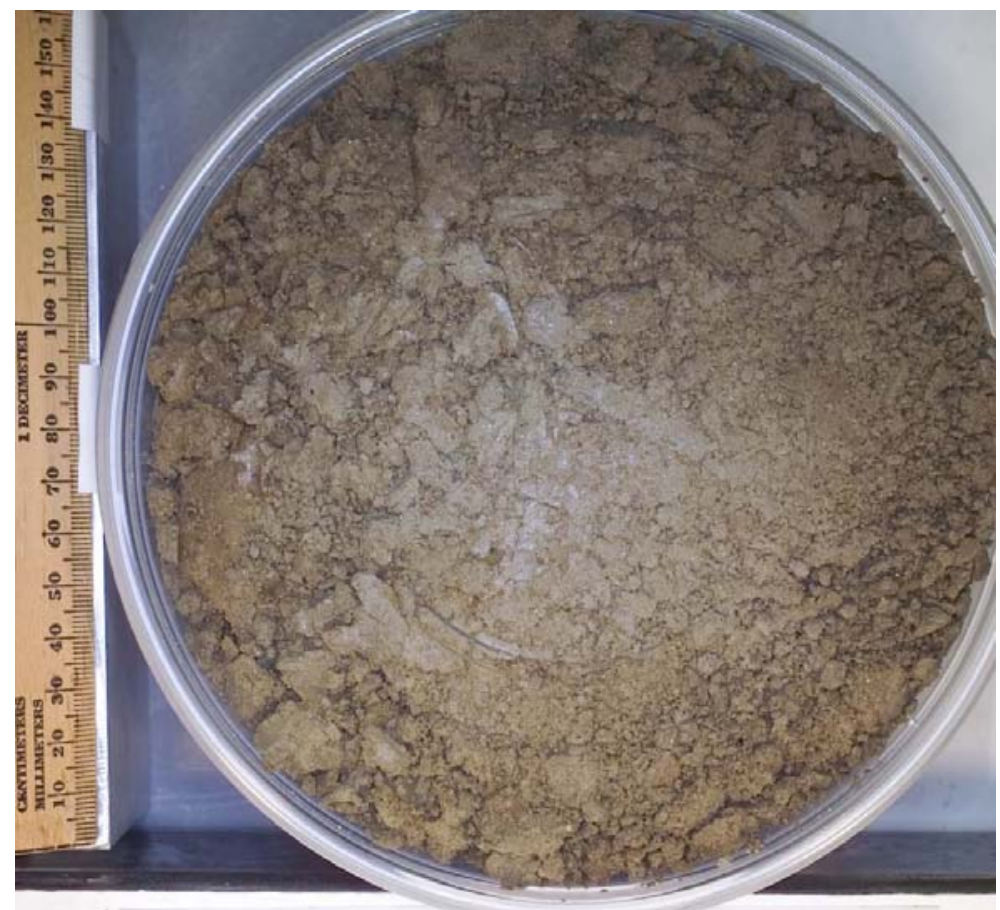

C5706 B1PL60 $\underset{\text { Depth from Chain-of-Custody }}{65.3-67.8} \mathrm{ft}$ LINER 3

Figure E.25. Photograph of Liner 3 from Sample B1PL60 from Borehole 399-3-22

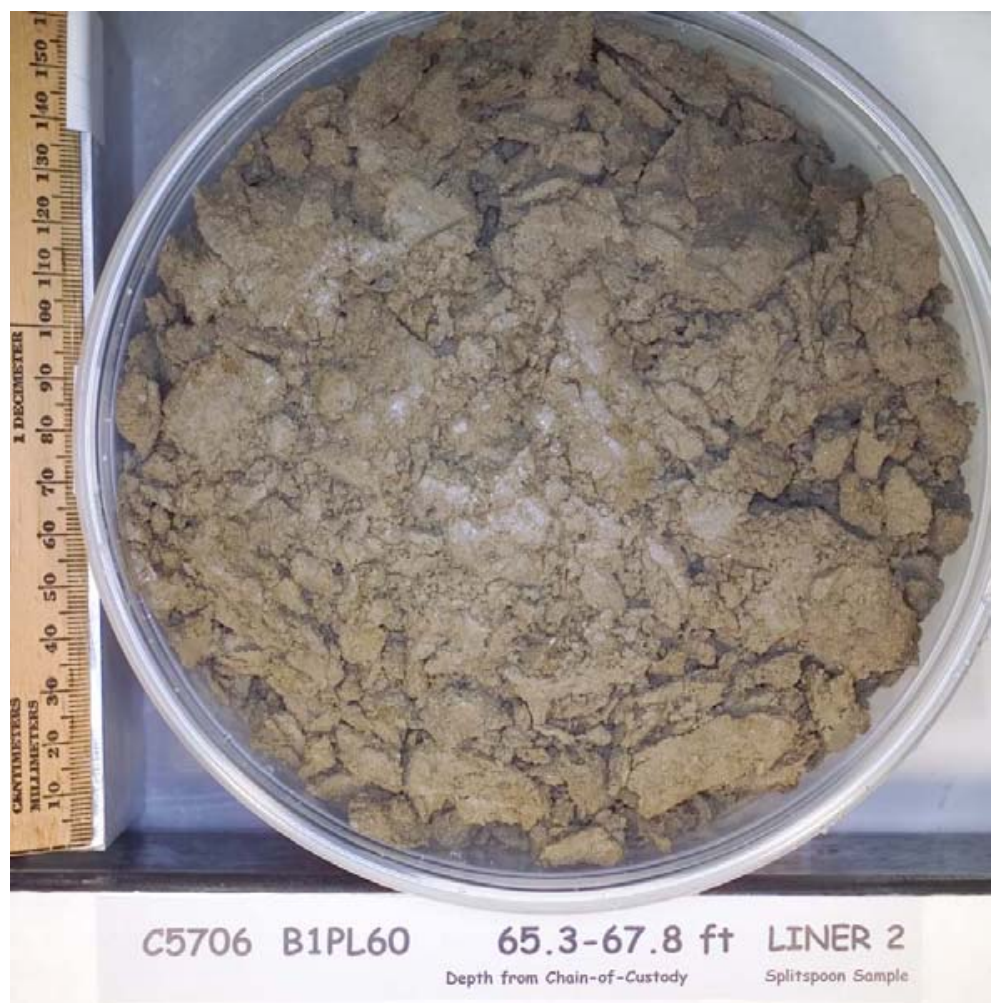

Figure E.26. Photograph of Liner 2 from Sample B1PL60 from Borehole 399-3-22 


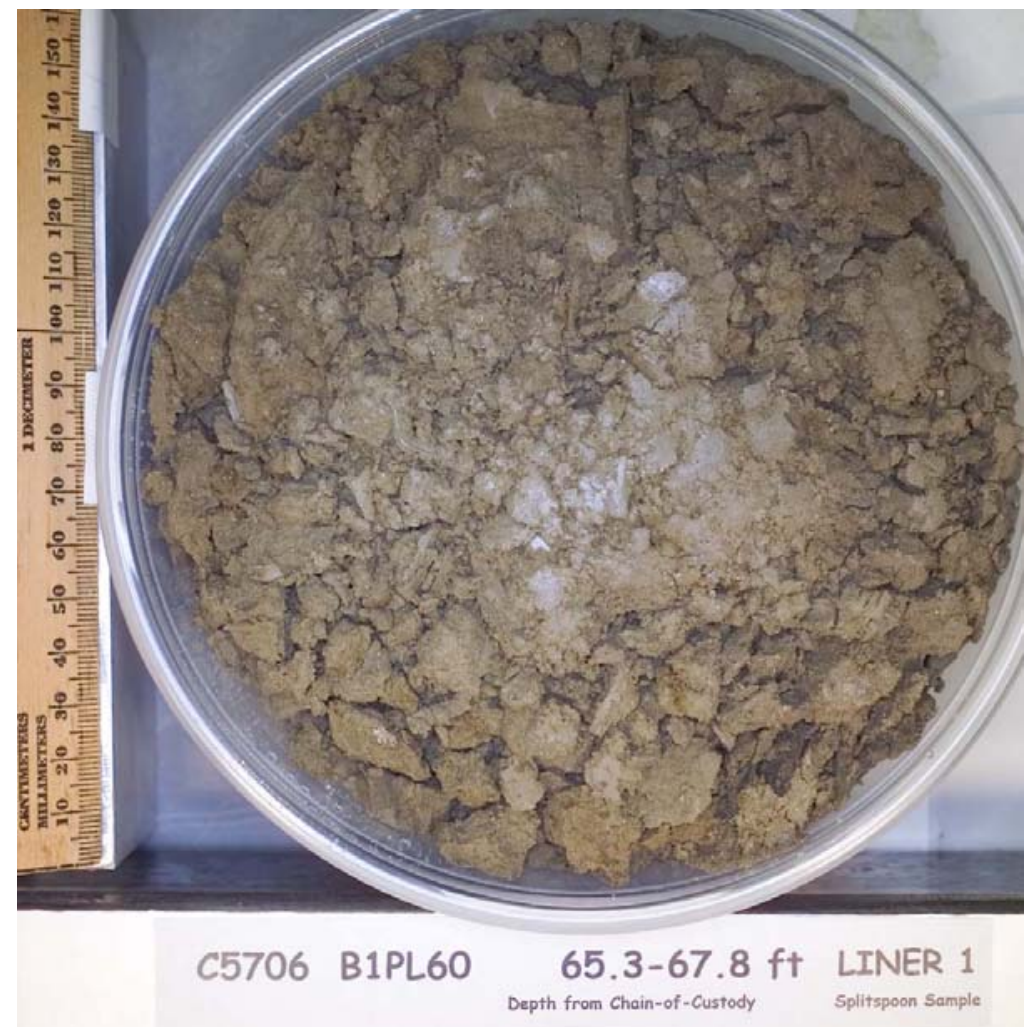

Figure E.27. Photograph of Liner 1 from Sample B1PL60 from Borehole 399-3-22

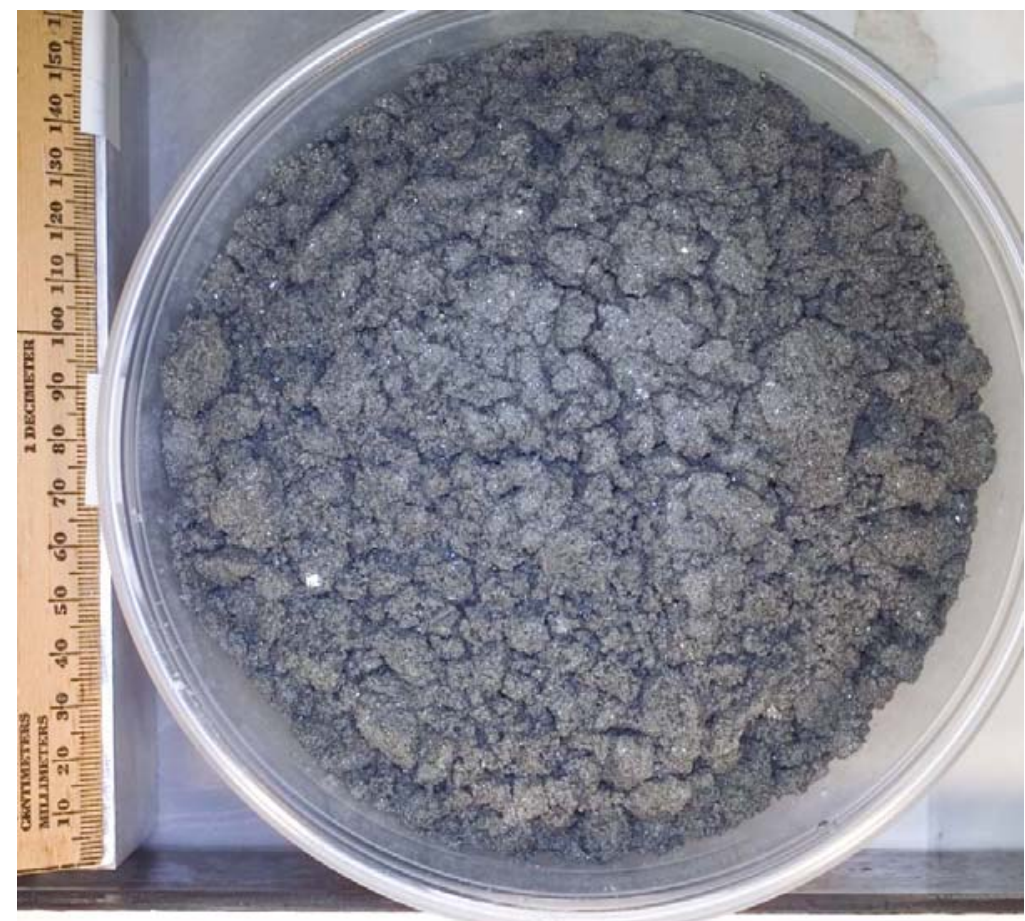

$$
\text { C5706 B1PL61 } \quad 81.5-84.0 \mathrm{ft} \text { LINER } 4
$$

Figure E.28. Photograph of Liner 4 from Sample B1PL61 from Borehole 399-3-22 


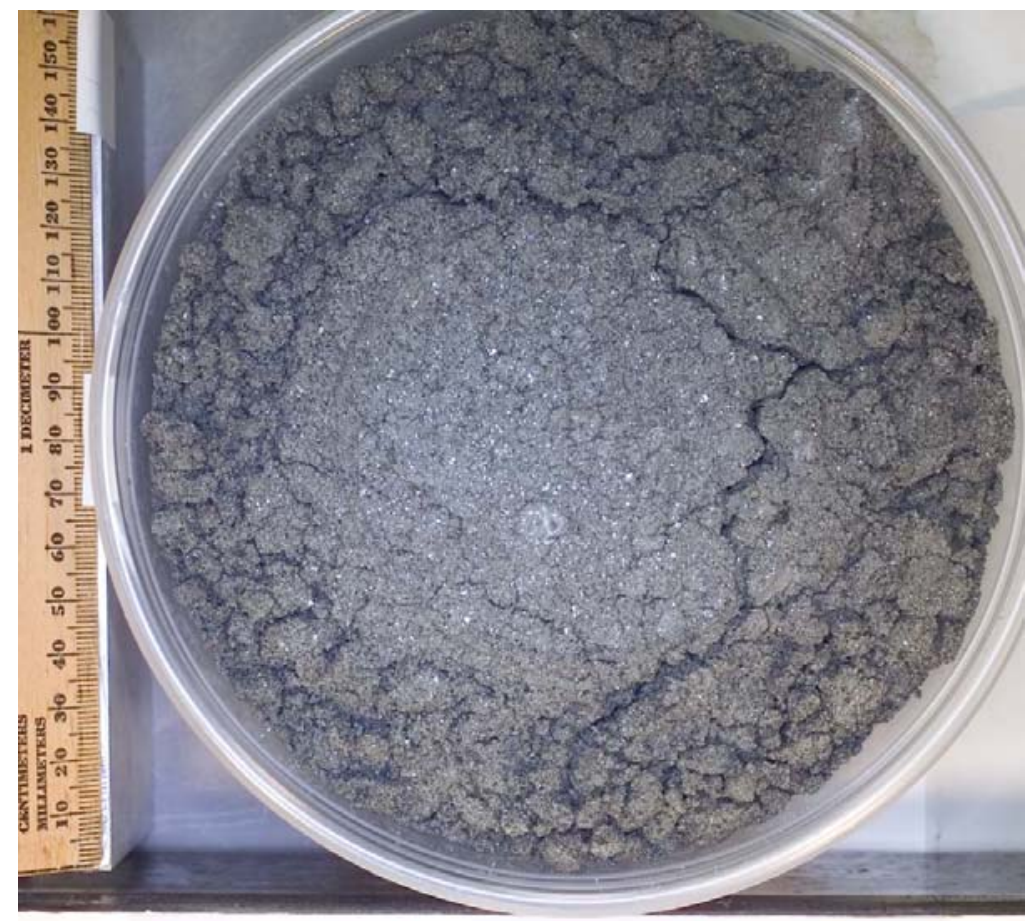

C5706 B1PL61 $\underset{\substack{\text { Depth from Chain-of-Custody }}}{\text { LINTER } 3}$

Figure E.29. Photograph of Liner 3 from Sample B1PL61 from Borehole 399-3-22

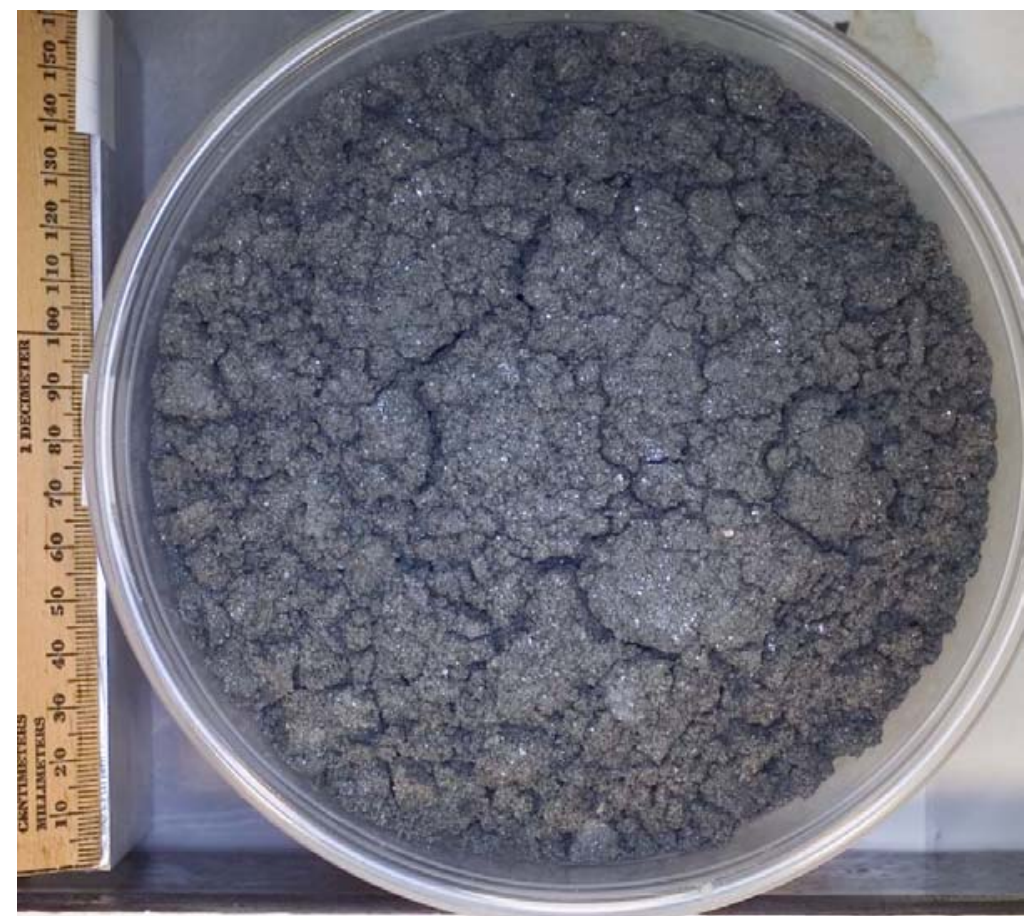

$$
\text { C5706 B1PL61 } \begin{array}{r}
81.5-84.0 \\
\text { Depth from Chain-of-Custody }
\end{array} \underset{\text { LIN Liltspoon Sample }}{\text { LIN } 2}
$$

Figure E.30. Photograph of Liner 2 from Sample B1PL61 from Borehole 399-3-22 


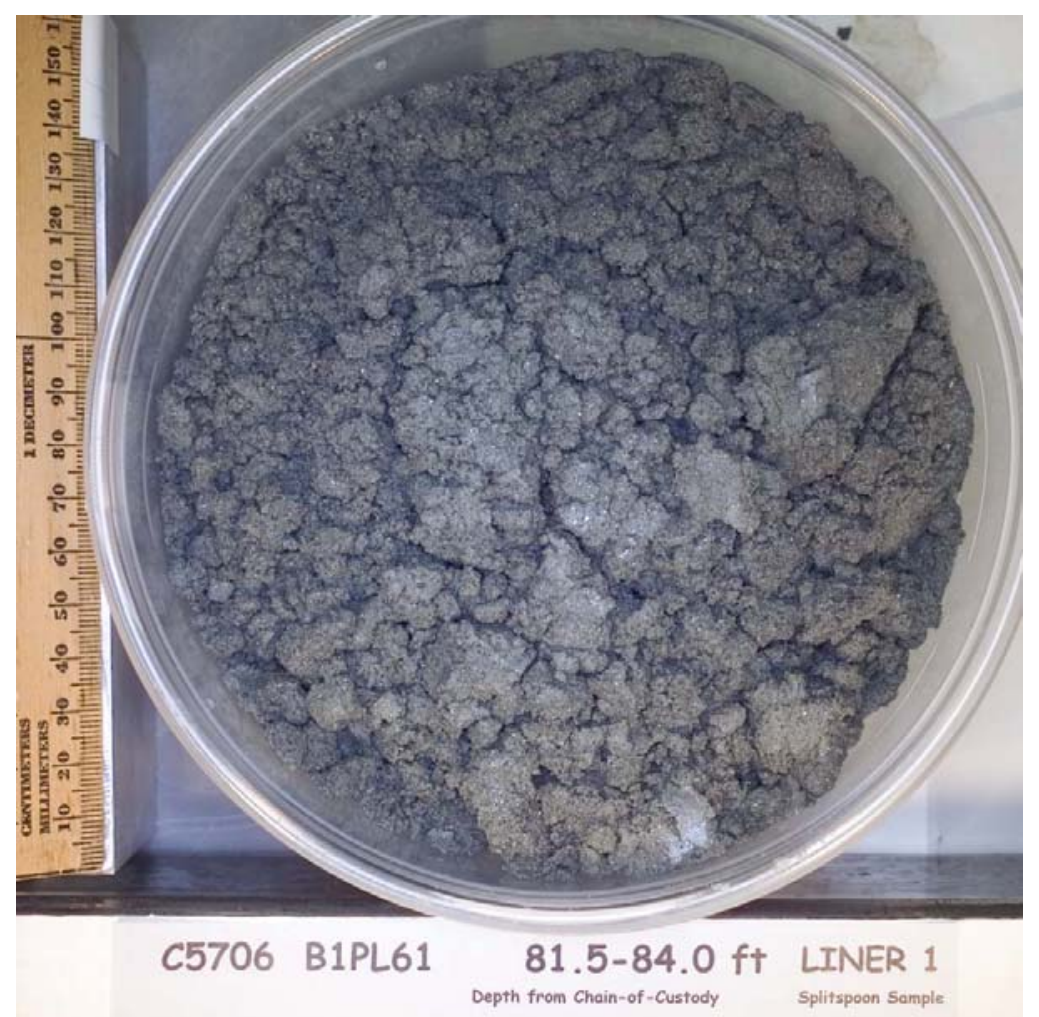

Figure E.31. Photograph of Liner 1 from Sample B1PL61 from Borehole 399-3-22 


\section{Appendix F}

\section{Stiff Diagrams of Groundwater Samples Collected from the VOC Wells}





\section{9-2-5 (C5708) Selected Depth Discrete Water Sample Results}

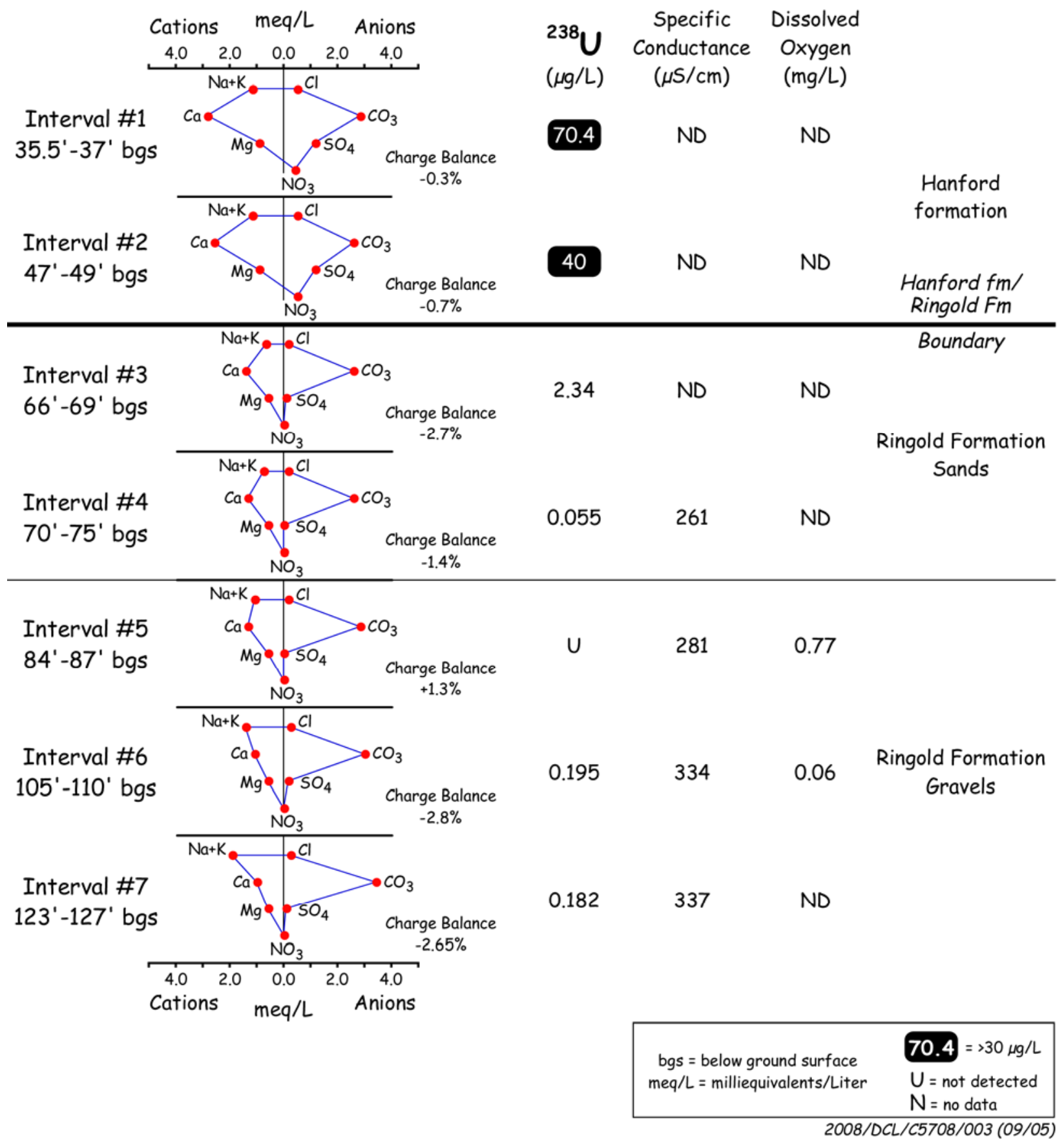

Figure F.1. Chemical Data for Groundwater Samples Collected from Well 399-2-5 


\section{9-4-14 (C5707) Selected Depth Discrete Water Sample Results}

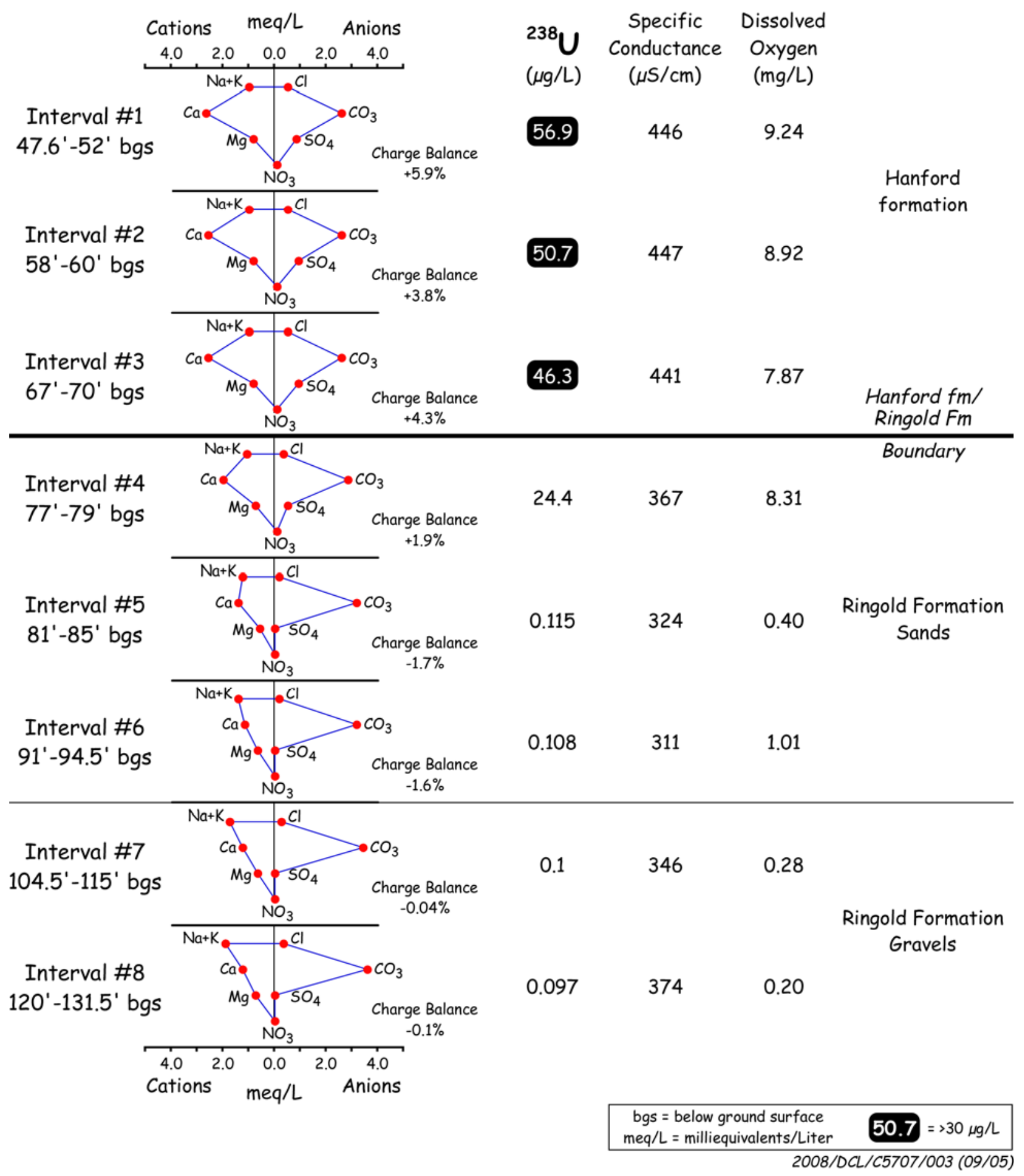

Figure F.2. Chemical Data for Groundwater Samples Collected from Well 399-4-14 


\section{9-3-22 (C5706) Selected Depth Discrete Water Sample Results}

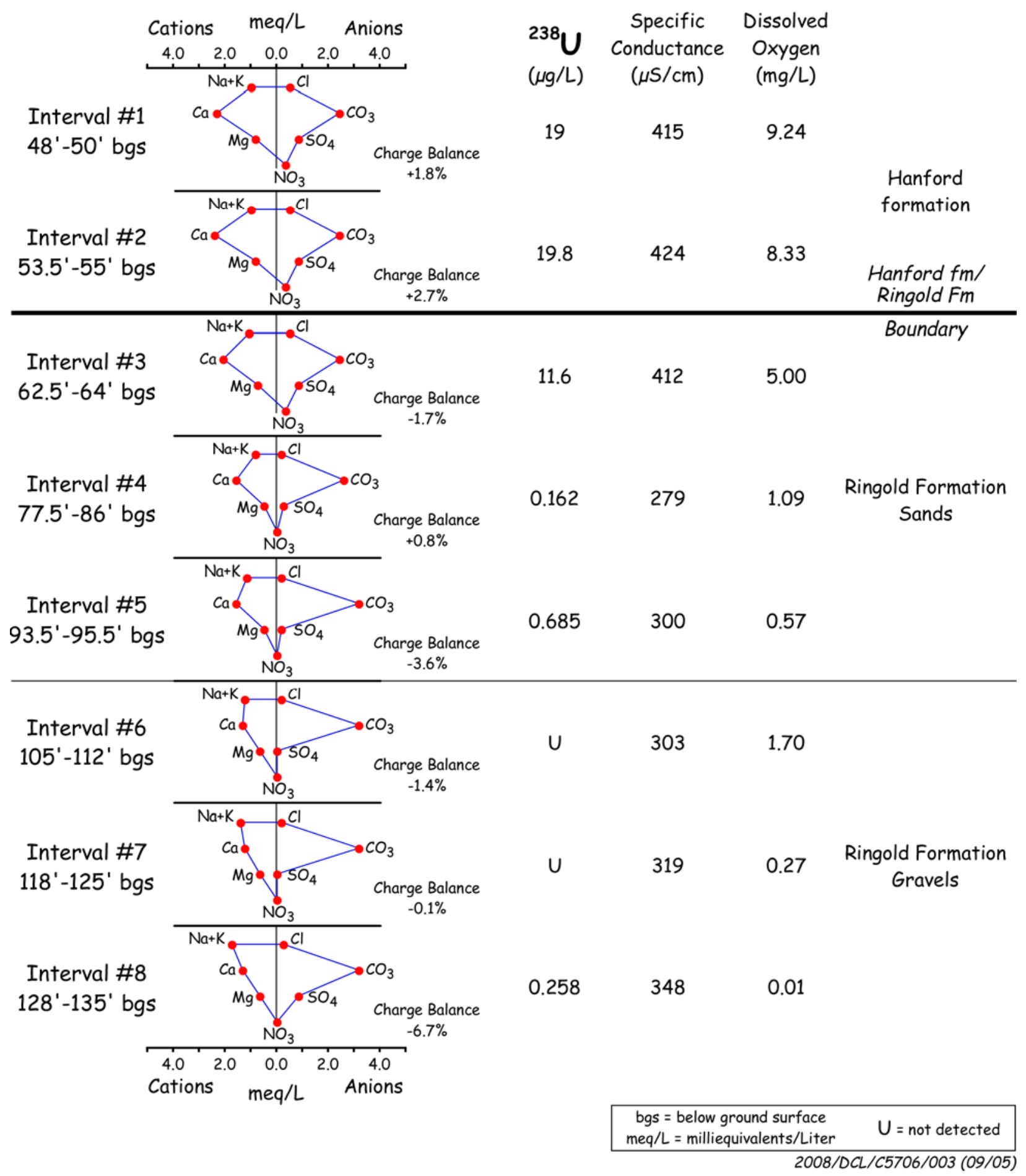

Figure F.3. Chemical Data for Groundwater Samples Collected from Well 399-3-22 



\section{Distribution}

No. of

Copies

7 DOE-Richland

KM Thompson (5)

JP Sands

J Zeisloft

1 EPA-Richland

AL Boyd

$1 \quad$ Ecology

J Price

8 Fluor Hanford, Inc.

JV Borghese (5)

MJ Hartman

JW Lindberg

BA Williams
B1-46

A6-38

A3-04

A3-04

H0-57

E6-44

E6-35

E6-35

E6-44
No. of

Copies

2 Washington Closure Hanford, Inc.

ET Feist

H4-22

JA Lerch

H4-22

23 Pacific Northwest National Laboratory

BN Bjornstad

CF Brown (10)

K6-81

JS Fruchter

P7-22

JA Horner

K6-96

DC Lanigan

K6-96

MJ Nimmons

K6-75

RE Peterson

K6-96

RJ Serne

K6-75

RM Smith

P7-22

PD Thorne

K6-96

MJ Truex

K6-96

W Um

K6-96

MD Williams

P7-22

K6-96

SB Yabusaki

K9-36 


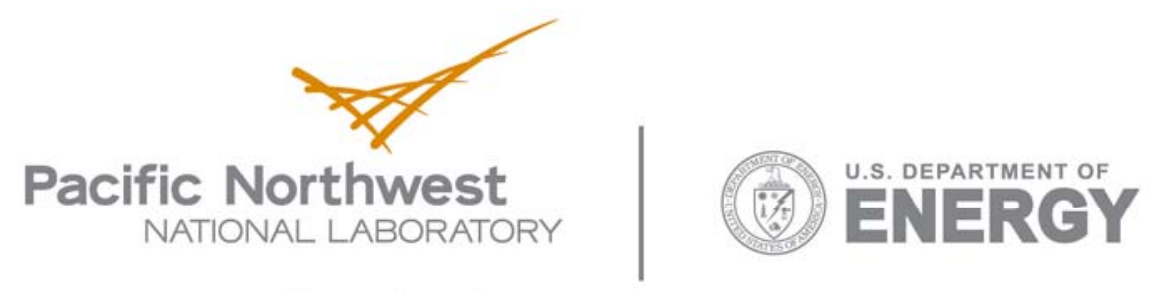

902 Battelle Boulevard

P.O. Box 999

Richland, WA 99352

1-888-375-PNNL (7665)

www.pnl.gov 